\title{
EXPERIMENTAL STUDY OF THE PERFORMANCE OF A VERTICAL AND A HORIZONTAL GROUND LOOPS COUPLED TO A GROUND SOURCE HEAT PUMP SYSTEM
}

\author{
By \\ Waleed Saeed Alzahrani \\ Bachelor of Engineering (Mechanical Engineering) \\ King Fahd University of Petroleum and Minerals \\ Dhahran, Saudi Arabia, 2009
}

A Thesis

Presented to Ryerson University

In partial fulfillment of the

requirements for the degree of

Master of Applied Science

In the program of

Mechanical and Industrial Engineering

Toronto, Ontario, Canada, 2014

(C) Waleed Saeed Alzahrani, 2014 


\section{AUTHOR'S DECLARATION}

I hereby declare that I am the sole author of this thesis. This is a true copy of the thesis, including any required final revisions, as accepted by my examiners.

I authorize Ryerson University to lend this thesis to other institutions or individuals for the purpose of scholarly research

I further authorize Ryerson University to reproduce this thesis by photocopying or by other means, in total or in part, at the request of other institutions or individuals for the purpose of scholarly research.

I understand that my thesis may be made electronically available to the public. 


\title{
EXPERIMENTAL STUDY OF THE PERFORMANCE OF A VERTICAL AND A HORIZONTAL GROUND LOOPS COUPLED TO A GROUND SOURCE HEAT PUMP SYSTEM
}

\author{
Waleed Saeed Alzahrani \\ Master of Applied Science \\ Program of Mechanical and Industrial Engineering \\ Ryerson University, Toronto, Ontario, Canada, 2013
}

\section{ABSTRACT}

The performance of vertical and horizontal ground loops coupled to a Ground-Source Heat Pump (GSHP) was investigated under four different scenarios. For this purpose, an experimental set-up was designed and constructed at the Archetype Sustainable houses in Vaughan, Ontario, Canada. In the first two tests, the two vertical ground loops coupled to the GSHP were tested in heating, and cooling modes. In heating mode, the GSHP COP ranged between 2.7 and 3.15. In cooling mode, the GSHP performed better than the heating mode with COP range of 3.75 and 5.4. In the last two tests, two scenarios were tested to compare the horizontal and the vertical ground loops in cooling mode. In the first scenario, the ground loop flow was divided equally between the loops and the GSHP overall COP was 5.42. The last test used equal Reynolds number in both loops and the GSHP overall COP was 5.36. 


\section{ACKNOWLEDGEMENTS}

The author would like to express his deepest appreciation to Dr. Wey Leong and Dr. Alan Fung for their kind support, guidance and encouragement throughout the project. The author is ever grateful to Dahai Zhang, a Ph.D. candidate for his generous help. The author would also express special thanks to Mr. David Nixon and Gil Amdurski of the Toronto and Region Conservation Authority for their concerted effort and help in implementing the instrumentation and the monitoring system. The author is also grateful for Mr. Brian Beatty from GeoEnergy Solutions Inc.

The author is very grateful for the King Abdullah Foreign Scholarship Program and the Saudi Arabian Cultural Bureau in Canada for their support and guidance.

I would finally like to thank my respected parents and my family for the unconditional love and support and for allowing me to realize my own potential. All the support they have provided me over the years was the greatest gift anyone has ever given me. 


\section{Table of Contents}

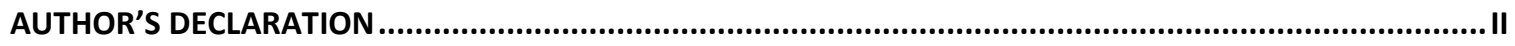

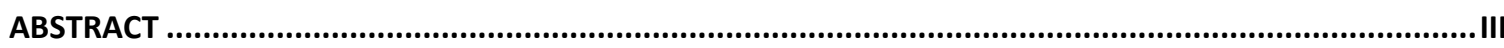

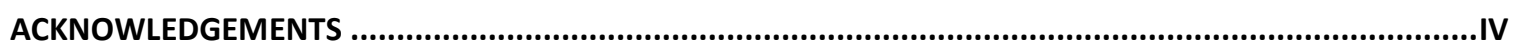

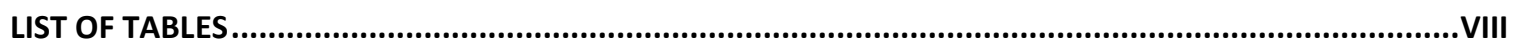

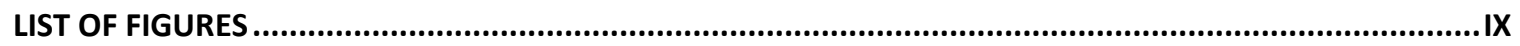

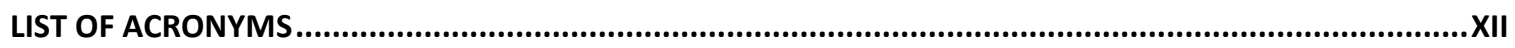

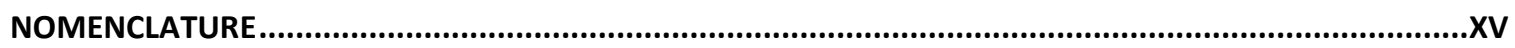

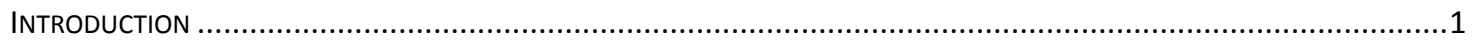

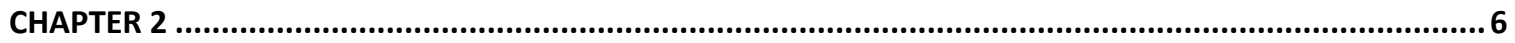

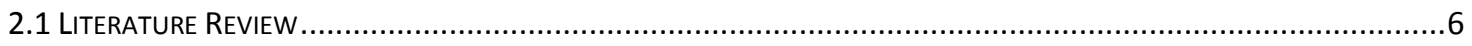

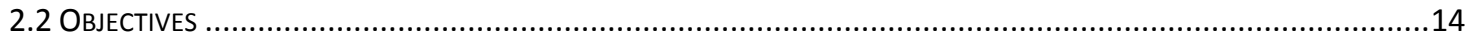

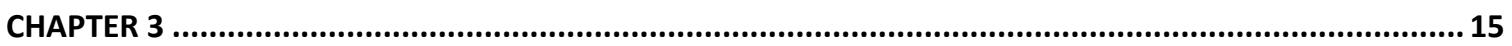

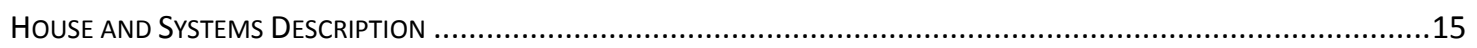

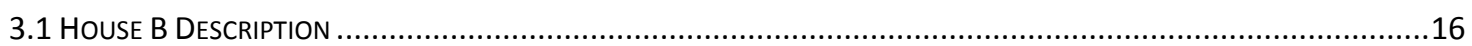

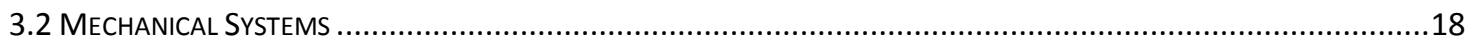

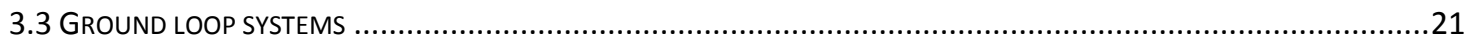

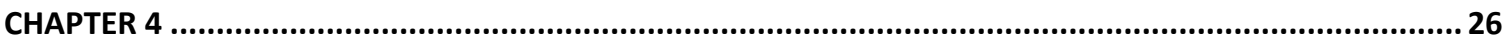

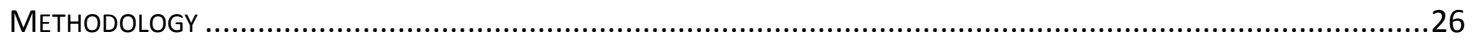

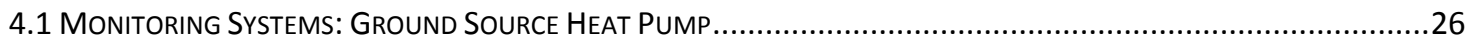

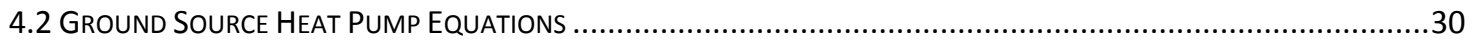

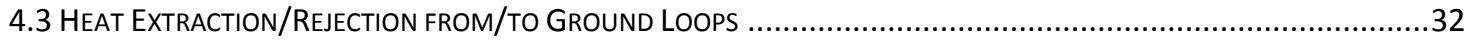

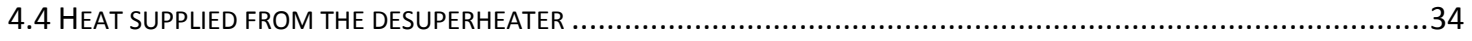

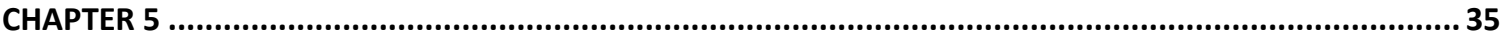

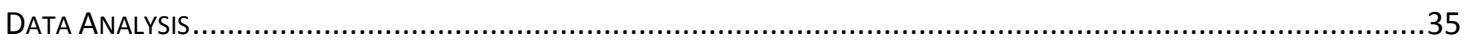

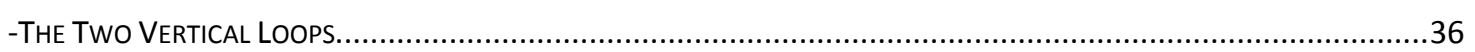

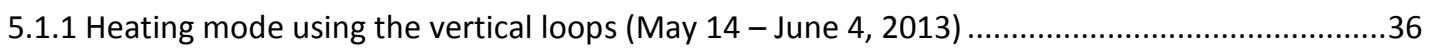

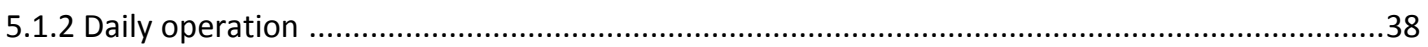


5.1.3 Entering Source Temperature (EST) and Entering Load Temperature (ELT) ........................41

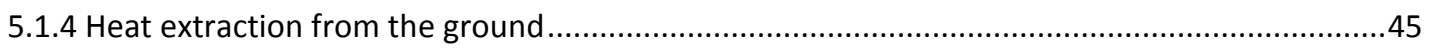

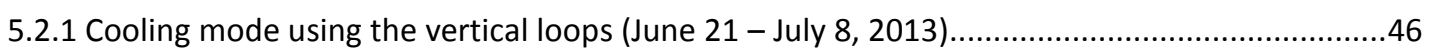

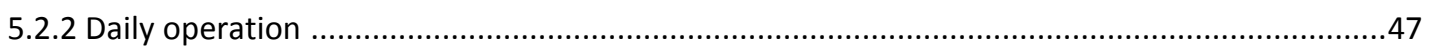

5.2.3 Entering Sink Temperature (EST) and Entering Load Temperature (ELT) ...............................50

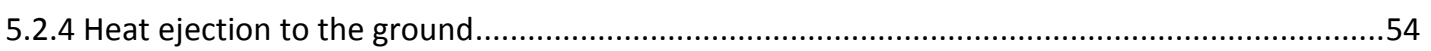

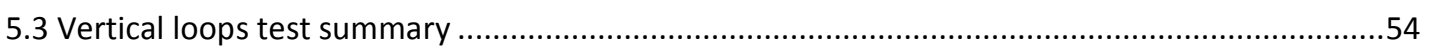

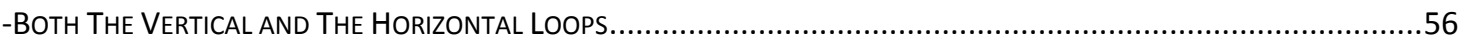

5.4.1 Cooling mode using the vertical and the horizontal loops with equal flow (July 19 - August 7, 2013) .56

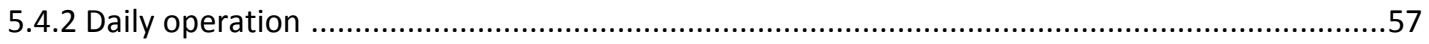

5.4.3 Entering Sink Temperature (EST) and Entering Load Temperature (ELT) ...........................60

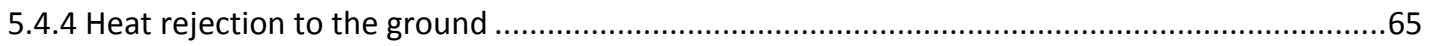

5.5.1 Cooling mode using the vertical and the horizontal loops with equal Reynolds number (August

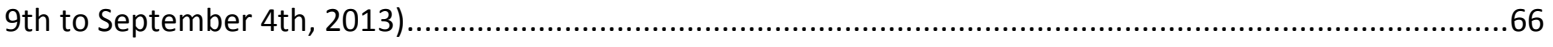

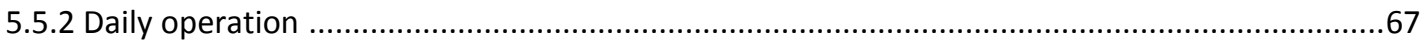

5.5.3 Entering Sink Temperature (EST) and Entering Load Temperature (ELT) ............................69

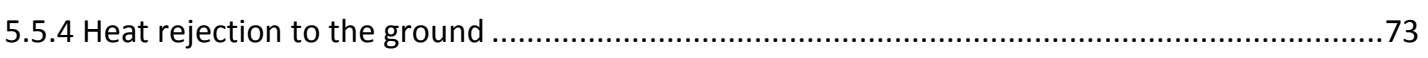

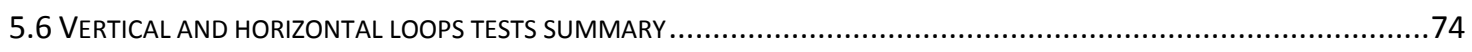

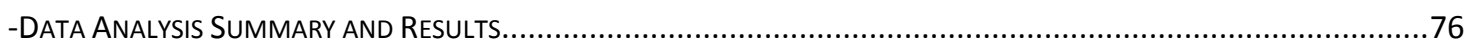

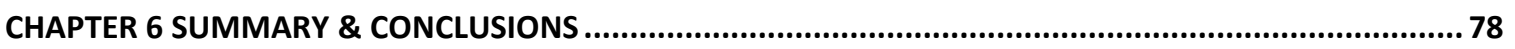

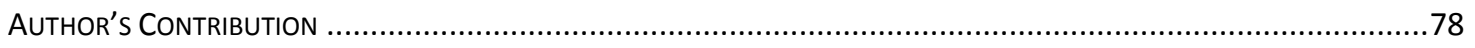

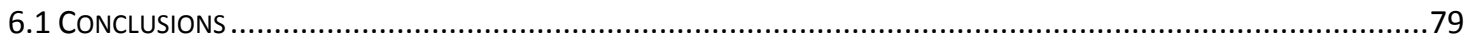

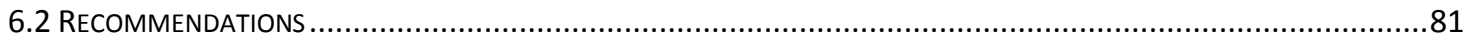

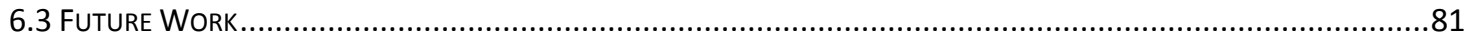

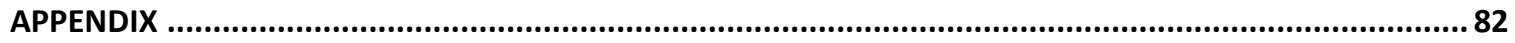

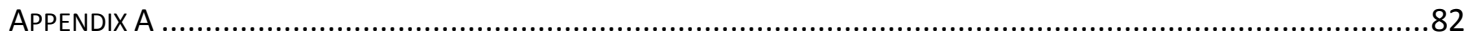

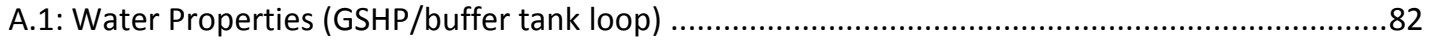

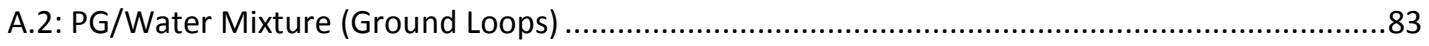

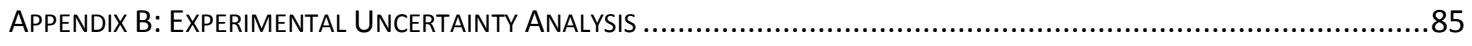

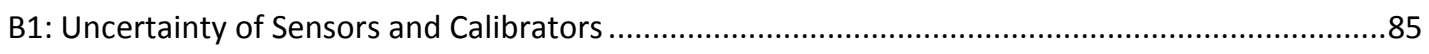

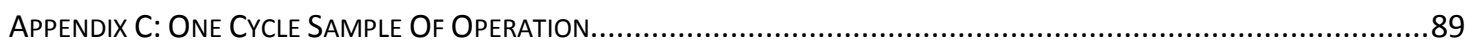




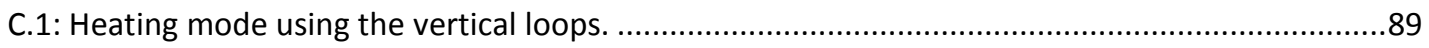

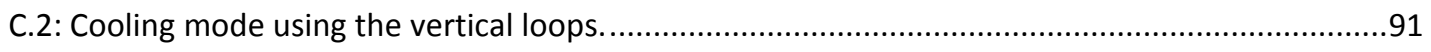

C.3: Cooling mode using the vertical and the horizontal loops with equal flow. .............................93

C.4: Cooling mode using the vertical and the horizontal loops with equal Reynolds number...........95

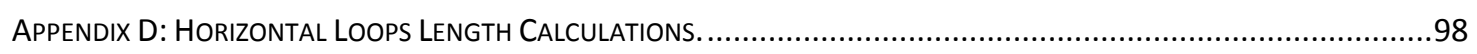

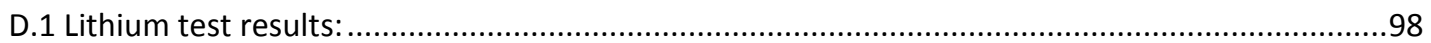

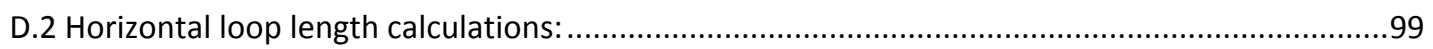

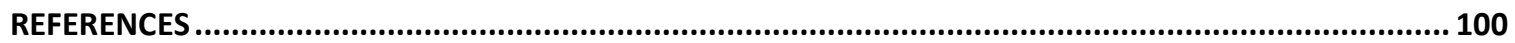




\section{LIST OF TABLES}

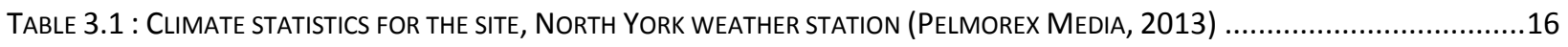

TABLE 3.2 : BASIC DESIGN FEATURES OF HOUSE-B (ZHANG ET AL., 2011) ............................................................................17

TABLE 3.3 : STRUCTURAL FEATURES Of HOUSE B (BARUA, 2010) ...................................................................................17

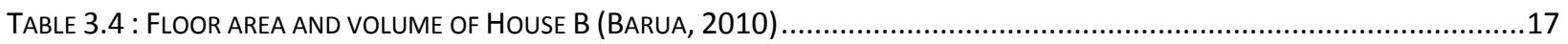

TABLE 3.5 : MeCHANICAL SYSTEM TECHNICAL INFORMATION (SAFA, 2012) .....................................................................20

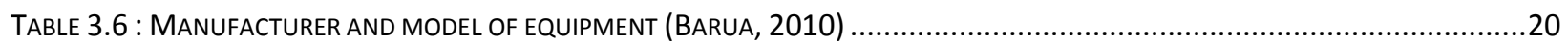

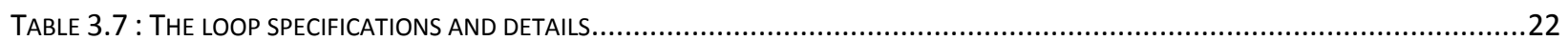

TABLE 3.8 : SUMMARY OF THE THERMAL CONDUCTIVITY TEST AND THE RESULTS (GEOENERGY, 2011) ..........................................24

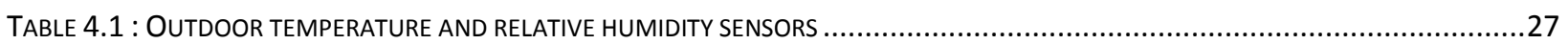

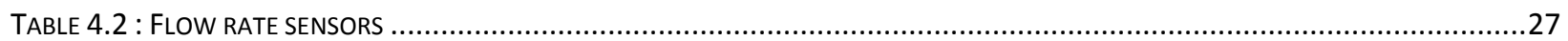

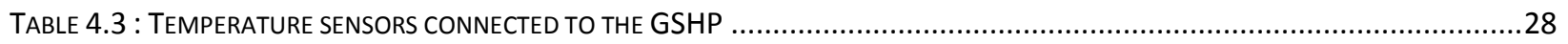

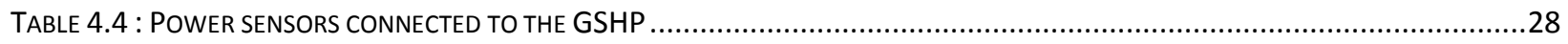

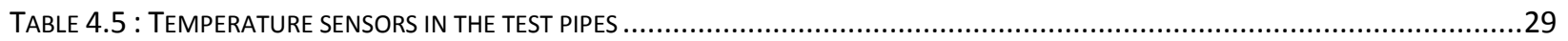

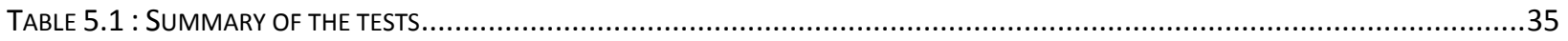

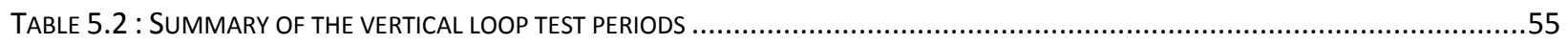

TABLE 5.3 : SUMMARY OF VERTICAL AND THE HORIZONTAL LOOPS TEST PERIODS...............................................................75

TABLE 5.4 : COMPARISON OF THE COOLING AND HEATING SEASONAL PERFORMANCE OF THE GSHP WITH DIFFERENT GROUND LOOPS.....76

TABLE 5.5 : COMPARISON OF COOLING SEASONAL PERFORMANCE OF THE GSHP USING BOTH GROUND LOOPS ..............................77

TABLE A.1 : DENSITY AND SPECIFIC HEAT OF WATER (ASHRAE HANDBOOK, 2009) .........................................................83

TABLE A.2 : DENSITY AND SPECIFIC HEAT OF 20\% PG AND 80\% WATER (ASHRAE HANDBOOK, 2009) ....................................84

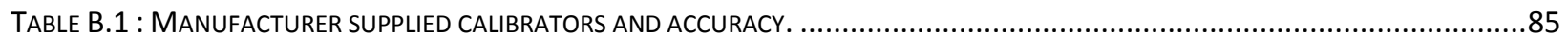

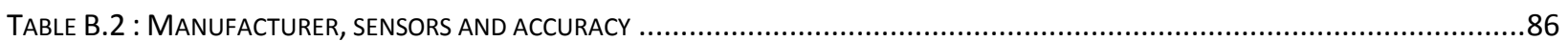

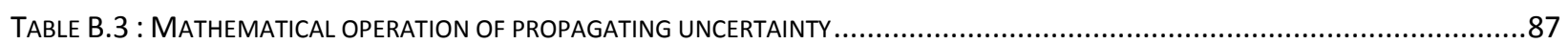

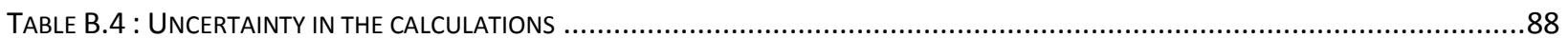




\section{LIST OF FIGURES}

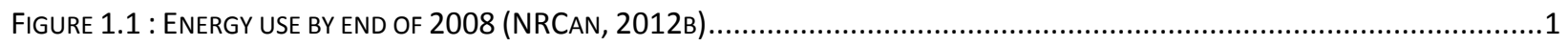

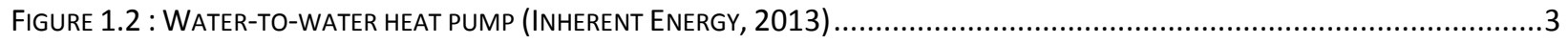

FIGURE 1.3 : THE REFRIGERATION CYCLE IN HEATING MODE OF A TYPICAL HEAT PUMP UNIT (NRCAN, 2005) ...................................

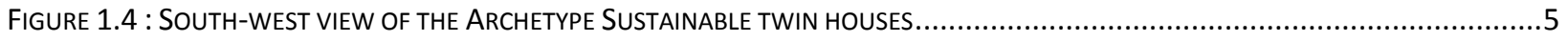

Figure 3.1 : Location of THE TWIN hOUSES AT THE LIVING City CAMPUS AT KORTRIGHT CENTRE (LATITUDE $=43.8317^{\circ}$, LONGITUDE $=$

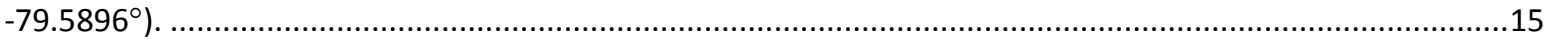

FIGURE 3.2 : LAYOUT OF HVAC SYSTEM AND MONITORING POINTS IN HOUSE-B AND IN-LAW SUITE..........................................19

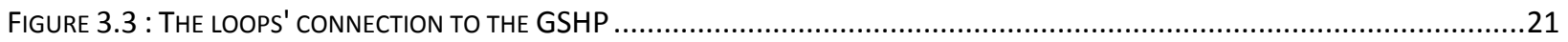

FIGURE 3.4 : FLOW CONTROL DIAGRAMS (BLUE: SUPPLY, RED: RETURN, BLACK: NO FLOW) ...............................................22

FIGURE 3.5 : THE VERTICAL LOOPS CONFIGURATION (LEFT) AND THE HORIZONTAL LOOPS CONFIGURATION (RIGHT)...........................23

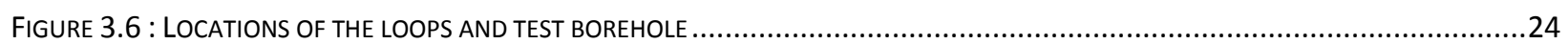

FIGURE 3.7 : TEST BOREHOLE LOG AND CONSTRUCTION DETAILS (GEOENERGY, 2011) ........................................................25

FIGURE 4.1 : SCHEMATIC OF THE GSHP IN HOUSE B AND THE GROUND LOOP FLOW CONTROL SYSTEM ......................................27

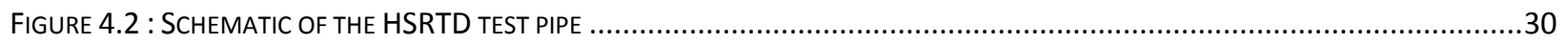

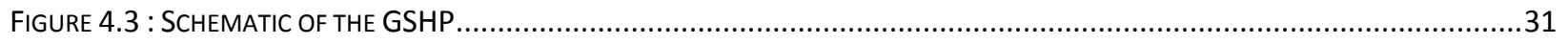

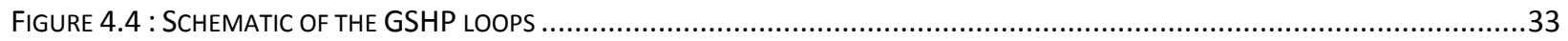

FIGURE 5.1 : BUFFER-TANK PUMP, GROUND-LOOP PUMPS, COMPRESSOR, AND TOTAL POWER DRAW WITH TIME ............................37

FIGURE 5.2 : DAILY OPERATING HOURS \& NUMBER OF CYCLES OF THE GSHP SYSTEM VS. DAILY AVERAGE OUTDOOR TEMPERATURE ........39

FIGURE 5.3 : DAILY HEATING AND CONSUMPTION OF THE GSHP SYSTEM VS. DAILY AVERAGE OUTDOOR TEMPERATURE.......................39

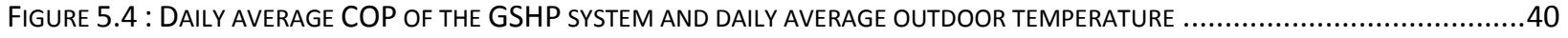

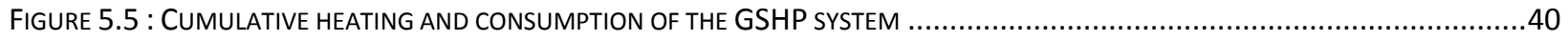

FIGURE 5.6 : DAILY ELECTRICITY CONSUMPTION AND HEATING OUTPUT VS. DAILY AVERAGE OUTDOOR TEMPERATURE ........................41

FIGURE 5.7 : POWER DRAW VS. FLUID RETURN TEMPERATURE FROM THE GROUND LOOP...................................................42

FIGURE 5.8 : HEAT OUTPUT VS. FLUID RETURN TEMPERATURE FROM THE GROUND LOOP ..................................................42

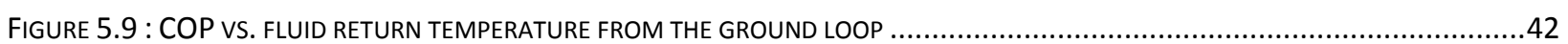

FIGURE 5.10 : COP, HEAT OUTPUT \& POWER DRAW VS. FLUID RETURN TEMPERATURE FROM THE GROUND LOOP TO GSHP .................43

FIGURE 5.11 : COP VS. SUPPLY TEMPERATURE FROM THE BUFFER TANK TO GSHP ..........................................................44

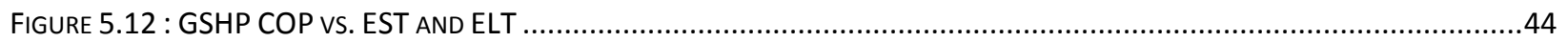

FIGURE 5.13 : HEAT EXTRACTION FROM THE VERTICAL GROUND LOOPS AND DAILY AVERAGE OUTDOOR TEMPERATURE.......................45

FIGURE 5.14 : BUFFER-TANK PUMP, GROUND-LOOP PUMPS, COMPRESSOR AND TOTAL POWER DRAW WITH TIME ...........................46

FIGURE 5.15 : DAILY OPERATING HOURS \& NUMBER OF CYCLES OF THE GSHP SYSTEM VS. DAILY AVERAGE OUTDOOR TEMPERATURE .....47 
FIGURE 5.16 : DAILY COOLING AND CONSUMPTION OF THE GSHP SYSTEM VS. DAILY AVERAGE OUTDOOR TEMPERATURE

FIGURE 5.17 : DAILY AVERAGE COP OF THE GSHP SYSTEM AND DAILY AVERAGE OUTDOOR TEMPERATURE ...................................48

FIGURE 5.18 : CUMULATIVE COOLING AND CONSUMPTION OF THE GSHP SYSTEM ..............................................................49

FIGURE 5.19 : DAILY ELECTRICITY CONSUMPTION AND COOLING OUTPUT VS. DAILY AVERAGE OUTDOOR TEMPERATURE.......................50

FIGURE 5.20 : POWER DRAW VS. FLUID RETURN TEMPERATURE FROM THE GROUND LOOP.......................................................51

FIGURE 5.21 : COOLING OUTPUT VS. FLUID RETURN TEMPERATURE FROM THE GROUND LOOP.................................................51

FIGURE 5.22 : COP VS. FLUID RETURN TEMPERATURE FROM THE GROUND LOOP .........................................................

FIGURE 5.23 : COP, COOLING OUTPUT \& POWER DRAW VS. SUPPLY TEMPERATURE FROM THE GROUND TO GSHP .........................52

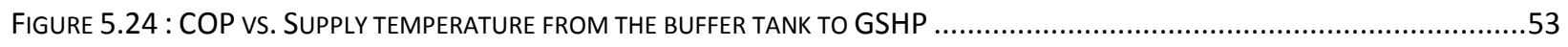

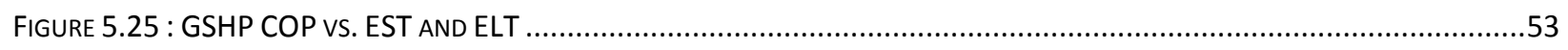

FIGURE 5.26 : HEAT INJECTION TO THE VERTICAL GROUND LOOPS AND DAILY AVERAGE OUTDOOR TEMPERATURE............................54

FIGURE 5.27 : BUFFER-TANK PUMP, GROUND-LOOP PUMPS, COMPRESSOR AND TOTAL POWER DRAW WITH TIME .............................57

FIGURE 5.28 : DAILY OPERATING HOURS \& NUMBER OF CYCLES OF THE GSHP SYSTEM VS. DAILY AVERAGE OUTDOOR TEMPERATURE ......58

FIGURE 5.29 : DAILY COOLING AND CONSUMPTION OF THE GSHP SYSTEM VS. DAILY AVERAGE OUTDOOR TEMPERATURE ....................58

FIGURE 5.30 : DAILY AVERAGE COP OF THE GSHP SYSTEM AND DAILY AVERAGE OUTDOOR TEMPERATURE .................................59

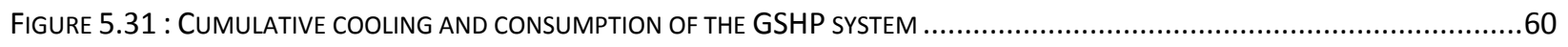

FIGURE 5.32 : DAILY ELECTRICITY CONSUMPTION AND COOLING OUTPUT VS. AVERAGE DAILY OUTDOOR TEMPERATURE.......................60

FIGURE 5.33 : POWER DRAW VS. FLUID RETURN TEMPERATURE FROM THE GROUND LOOP.......................................................61

FIGURE 5.34 : COOLING OUTPUT VS. FLUID RETURN TEMPERATURE FROM THE GROUND LOOP..................................................61

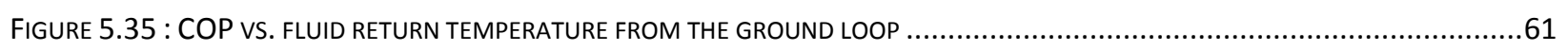

FIGURE 5.36 : COP, COOLING OUTPUT \& POWER DRAW VS. SUPPLY TEMPERATURE FROM THE GROUND TO GSHP ..........................62

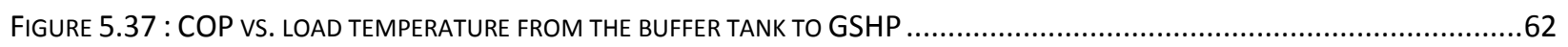

FIGURE 5.38 : THE GSHP AVERAGE SUPPLY AND RETURN TEMPERATURES FROM THE LOOPS AND FROM THE BUFFER TANK ..................63

FIGURE 5.39 : THE HORIZONTAL AND VERTICAL LOOPS AVERAGE SUPPLY AND RETURN TEMPERATURES FOR ALL CYCLES.......................63

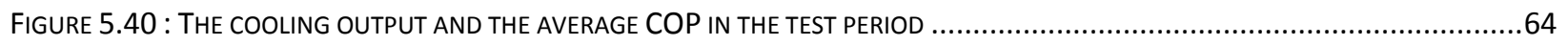

FIGURE 5.41 : HEAT REJECTION TO THE GROUND LOOPS AND DAILY AVERAGE OUTDOOR TEMPERATURE ......................................65

FIGURE 5.42 : BUFFER-TANK PUMP, GROUND-LOOP PUMPS, COMPRESSOR AND TOTAL POWER DRAW WITH TIME ............................66

FIGURE 5.43 : DAILY OPERATING HOURS \& NUMBER OF CYCLES OF THE GSHP SYSTEM VS. DAILY AVERAGE OUTDOOR TEMPERATURE .....67

FIGURE 5.44 : DAILY COOLING AND CONSUMPTION OF THE GSHP SYSTEM VS. DAILY AVERAGE OUTDOOR TEMPERATURE ....................67

FIGURE 5.45 : DAILY AVERAGE COP OF THE GSHP SYSTEM AND DAILY AVERAGE OUTDOOR TEMPERATURE ................................68

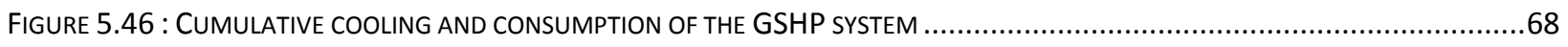

FIGURE 5.47 : DAILY ELECTRICITY CONSUMPTION AND COOLING OUTPUT VS. AVERAGE DAILY OUTDOOR TEMPERATURE......................69

FIGURE 5.48 : POWER DRAW VS. FLUID RETURN TEMPERATURE FROM THE GROUND LOOP....................................................69

FIGURE 5.49 : COOLING OUTPUT VS. FLUID RETURN TEMPERATURE FROM THE GROUND LOOP....................................................70 
FIGURE 5.50 : COP VS. FLUID RETURN TEMPERATURE FROM THE GROUND LOOP

FIGURE 5.51 : COP, COOLING OUTPUT \& POWER DRAW VS. SUPPLY TEMPERATURE FROM THE GROUND TO GSHP .........................70

FIGURE 5.52 : COP VS. SUPPLY TEMPERATURE FROM THE BUFFER TANK TO GSHP ..............................................................

FIGURE 5.53 : THE GSHP AVERAGE SUPPLY AND RETURN TEMPERATURES FROM THE LOOPS AND FROM THE BUFFER TANK FOR ALL CYCLES

FIGURE 5.54 : THE HORIZONTAL AND VERTICAL LOOPS AVERAGE SUPPLY AND RETURN TEMPERATURES FOR ALL CYCLES......................73

FIGURE 5.55 : THE COOLING OUTPUT AND THE COP AVERAGE OF ALL CYCLES IN THE TEST PERIOD ...........................................73

FIGURE 5.56 : HEAT REJECTION TO THE GROUND LOOPS AND DAILY AVERAGE OUTDOOR TEMPERATURE ......................................74

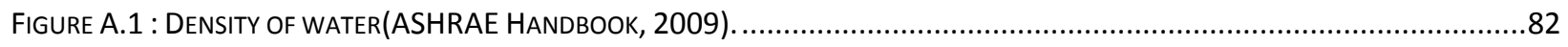

FIGURE A.2 : DENSITY OF 20\% PG AND 80\% WATER (ASHRAE HANDBOOK, 2009) .....................................................84

FIGURE C.1 : ONE CYCLE SAMPLE OF THE SUPPLY AND RETURN TEMPERATURES TO THE GSHP FROM THE BUFFER TANK ......................89

FIGURE C.2 : ONE CYCLE SAMPLE OF THE SUPPLY AND RETURN TEMPERATURES TO THE GSHP FROM THE VERTICAL LOOP....................89

FIGURE C.3 : ONE CYCLE SAMPLE OF THE POWER DRAW OF THE GSHP SYSTEM COMPONENTS............................................90

FIGURE C.4 : ONE CYCLE SAMPLE OF THE HEATING OUTPUT, POWER DRAW AND THE COP................................................90

FIGURE C.5 : ONE CYCLE SAMPLE OF THE SUPPLY AND RETURN TEMPERATURES TO THE GSHP FROM THE VERTICAL LOOP....................91

FIGURE C.6 : ONE CYCLE SAMPLE OF THE SUPPLY AND RETURN TEMPERATURES TO THE GSHP FROM THE BUFFER TANK .....................91

FIGURE C.7 : ONE CYCLE SAMPLE OF THE GSHP SYSTEM COMPONENTS POWER DRAW ....................................................92

FIGURE C.8 : ONE CYCLE SAMPLE OF THE COOLING OUTPUT, POWER DRAW AND THE COP....................................................

FIGURE C.9 : ONE CYCLE SAMPLE OF THE SUPPLY AND RETURN TEMPERATURES FROM THE VERTICAL AND HORIZONTAL GROUND LOOPS ...93

FIGURE C.10 : ONE CYCLE SAMPLE OF THE SUPPLY AND RETURN TEMPERATURES TO THE GSHP FROM THE GROUND LOOPS..................93

FIGURE C.11 : ONE CYCLE SAMPLE OF THE SUPPLY AND RETURN TEMPERATURES TO THE GSHP FROM THE BUFFER TANK ....................94

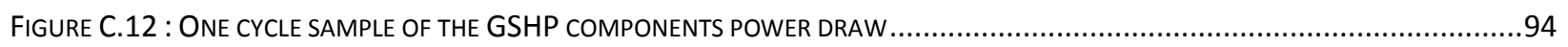

FIGURE C.13 : ONE CYCLE SAMPLE OF THE GSHP COOLING OUTPUT, POWER DRAW AND THE COP ........................................95

FIGURE C.14 : ONE CYCLE SAMPLE OF THE SUPPLY AND RETURN TEMPERATURES FROM THE VERTICAL AND HORIZONTAL GROUND LOOPS.95

FIGURE C.15 : ONE CYCLE SAMPLE OF THE SUPPLY AND RETURN TEMPERATURES TO THE GSHP FROM THE GROUND LOOPS..................96

FIGURE C.16 : ONE CYCLE SAMPLE OF THE SUPPLY AND RETURN TEMPERATURES TO THE GSHP FROM GROUND LOOPS AND THE BUFFER TANK

FIGURE C.17 : ONE CYCLE SAMPLE OF THE GSHP SYSTEM COMPONENTS POWER DRAW...................................................97

FIGURE C.18 : ONE CYCLE SAMPLE OF THE GSHP COOLING OUTPUT, POWER DRAW AND THE COP ..........................................97

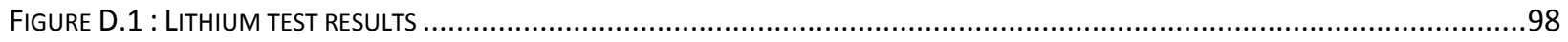




\section{LIST OF ACRONYMS}

AHU: Air Handling Unit

ASHRAE: American Society of Heating, Refrigeration, and Air-Conditioning Engineers

ASME: American Society of Mechanical Engineers

BILD: Building Industry and Land Development

Btu: British Thermal Unit

CDD: Cooling Degree Day $\left({ }^{\circ} \mathrm{C}\right.$-day $)$

CFP: Compact Field Point

COP: Coefficient of Performance

CSA: Canadian Standard Association

DAQ: Data Acquisition System

DB: Dry Bulb

DHW: Domestic Hot Water 
DHWT: Domestic Hot Water Tank

DOE: US Department of Energy

EER: Energy Efficiency Rating

ELT: Entering Load Temperature

EST: Entering Source/Sink Temperature

EWT: Entering Water Temperature

GAL: U.S. Gallon (3.78 Liters)

GHE: Ground Heat Exchanger

GHG: Greenhouse Gas

GPM: Gallon per Minute

GSHP: Ground-Source Heat Pump

HDD: Heating Degree Day $\left({ }^{\circ} \mathrm{C}\right.$-day)

HVAC: Heating, Ventilation, and Air Conditioning

IGSHPA: International Ground Source Heat Pump Association 
kW: Kilowatt

kWh: Kilowatt-hour

LEED: Leadership in Energy and Environmental Design

LPM: Litter Per Minute

NI: National Instrument

NRCan: Natural Resources Canada

PG: Propylene Glycol

PSIa: Pound-Force Per Square Inch Absolute

RTD: Resistance Temperature Detector

SCOP: Seasonal Coefficient of Performance

SEER: Seasonal Energy Efficiency Ratio

SQL: Structured Query Language

TOU: Time-of-use

TRCA: Toronto and Region Conservation Authority 


\section{NOMENCLATURE}

A

AT

$\mathrm{c}_{\mathrm{PG}}$

$\mathrm{c}_{\text {pwater }}$

$\mathrm{COP}_{\text {Heat }}$

$\mathrm{COP}_{\mathrm{Cool}}$

$\mathrm{C}_{\mathrm{r}}$

FL

$\mathrm{h}$

$\dot{\mathrm{m}}_{\mathrm{w}}$

$\dot{\mathrm{Q}}_{\text {Heat/cool }}$

$\dot{\mathrm{Q}}_{\text {Extracted /Injection }}$

$\mathrm{RH}$
Area, $\left(\mathrm{m}^{2}\right)$

Ambient air temperature, $\left({ }^{\circ} \mathrm{C}\right)$

Specific heat of $\mathrm{PG},(\mathrm{kJ} / \mathrm{kg} \cdot \mathrm{K})$

Specific heat of water, $(\mathrm{kJ} / \mathrm{kg} \cdot \mathrm{K})$

Heating coefficient of performance, $(\mathrm{kW} / \mathrm{kW})$

Cooling coefficient of performance, $(\mathrm{kW} / \mathrm{kW})$

Heat capacity rate ratio

Liquid flow rate, (GPM)

Specific enthalpy, $(\mathrm{kJ} / \mathrm{kg})$

Mass flow rate of water, $(\mathrm{kg} / \mathrm{s})$

Thermal power output, $(\mathrm{kW})$

Heat extracted from/injection to ground, $(\mathrm{kW})$

Relative humidity, (\%) 
$\mathrm{T}_{\mathrm{o}}$

$\mathrm{T}_{\mathrm{w}, \mathrm{O}}$

$\mathrm{T}_{\mathrm{w}, \mathrm{i}}$

UA

V

$\dot{V}$

$\mathrm{W}_{\text {Electrical }}$

\section{Greek symbols:}

$\rho_{P G}$

$\rho_{\text {water }}$

$\sigma$

$\varepsilon$
Temperature, $\left({ }^{\circ} \mathrm{C}\right)$

Inlet temperature, $\left({ }^{\circ} \mathrm{C}\right)$

Outlet temperature, $\left({ }^{\circ} \mathrm{C}\right)$

Water temperature leaving the system, $\left({ }^{\circ} \mathrm{C}\right)$

Water temperature entering the system, $\left({ }^{\circ} \mathrm{C}\right)$

Overall heat transfer coefficient, $\left(\mathrm{kW} /{ }^{\circ} \mathrm{C}\right)$

Total volume, $\left(\mathrm{m}^{3}\right)$

Volumetric flow rate, (LPM)

Electrical power, $(\mathrm{kW})$
Density of PG, $\left(\mathrm{kg} / \mathrm{m}^{3}\right)$

Density of water, $\left(\mathrm{kg} / \mathrm{m}^{3}\right)$

Absolute uncertainty

Relative uncertainty 


\section{CHAPTER 1}

\section{Introduction}

Due to increasing energy consumption and related environmental concerns, there is an ongoing drive to develop and implement cleaner and more sustainable energy sources. In addition, this has driven the developments and technologies to increase the efficiency and reduce energy loss in any given system. In Canada, the increase of commercial and institutional facilities' energy demands grew by over 35\% between 1990 and 2009. Also, due to the increase of the number of households and house sizes in the same period, energy consumption of the housing sector rose 37\% (NRCan, 2012a). Figure 1.1 shows that space heating, space cooling, and water heating account for $82 \%$ of the total residential building energy use and $60 \%$ of the commercial building energy use. In 2008, these sectors were responsible for $28 \%$ of the total Greenhouse Gas (GHG) emissions in Canada (NRCan, 2012b). To lower energy consumption and its associated GHG emissions in buildings, a number of strategies can be employed not only to reduce the energy demands but also to make the most of the energy used by increasing the efficiency. One of the most energy efficient mechanical systems that can provide space heating, space cooling and domestic hot water (DHW) is the ground source heat pump (GSHP).

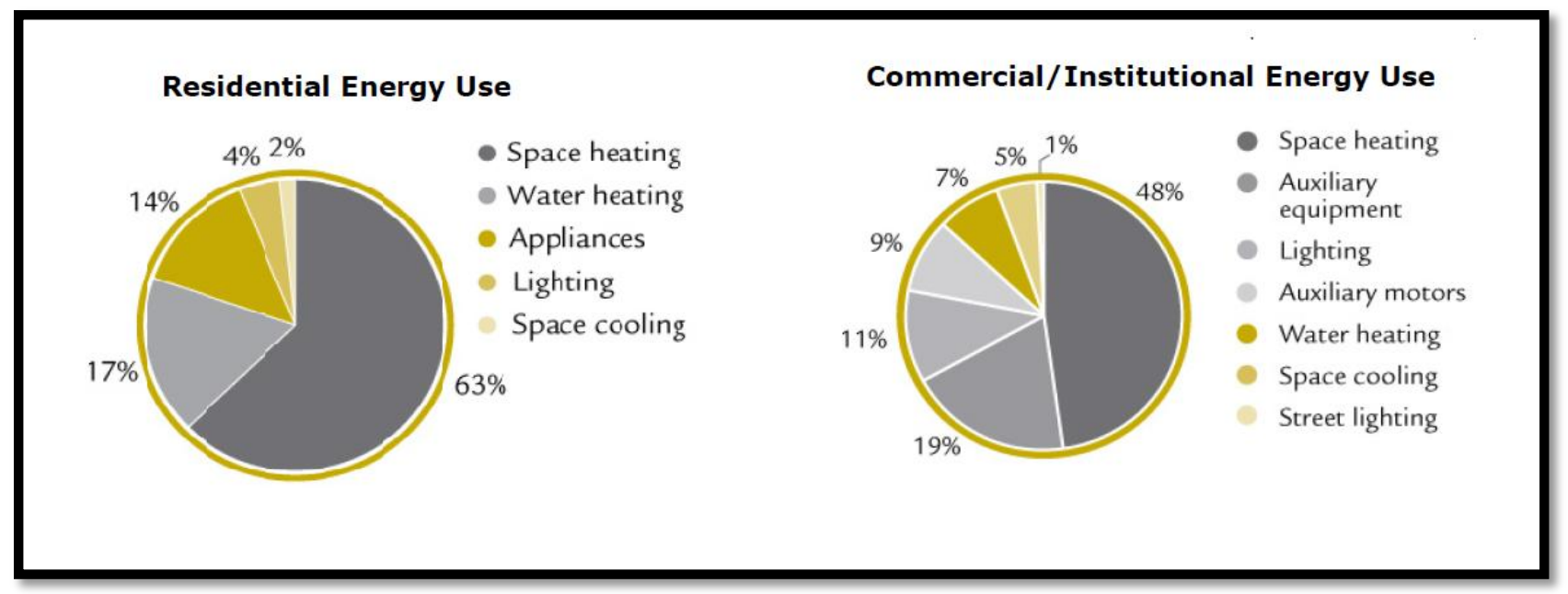

Figure 1.1 : Energy use by end of 2008 (NRCan, 2012b) 
The use of such technology can lower energy use in buildings. A ground source heat pump (GSHP) system has three major components: a heat pump, a ground loop, and a heating or cooling distribution system. Whether it is a water-to-water or water-to-air heat pump, it acts like a heat exchanger to transfer heat between the heating/cooling distribution system and the ground loop system and it uses the same cycle as a refrigerator (NRCan, 2005). The water-to-water designation indicates that the fluid carrying heat to and from the ground loop is water or a water/antifreeze mixture and that the heat distribution system relies on water as shown in Figure 1.2. Whereas the water-to-air designation indicates that the heat distribution system relies on air.

The heat pump operates using the same cycle as a refrigerator. In heating mode, the circulating water/antifreeze mixture in the ground loop absorbs heat from the ground and then feeds it to a heat exchanger called the evaporator inside the heat pump. The heat from the ground loop is absorbed by the refrigerant on the other side of the evaporator, which boils and turns the refrigerant from its liquid state to a low pressure gas. Then, this gas passes into the compressor in which it increases its pressure and, as a consequence, its temperature. After that, this high pressure and high temperature gas goes to another heat exchanger called the condenser. This is where the heat is absorbed from the refrigerant by water on the other side, in the case of a waterto-water heat pump, or by air, in the case of a water-to-air heat pump. After dumping its heat, the refrigerant transforms into a liquid state and then goes through an expansion valve to reduce its pressure and temperature. Now, this low temperature liquid flows to the evaporator, and the cycle starts again. In cooling mode, the cycle is reversed where heat inside the building is released to the ground using the same principle but the condenser becomes the evaporator and the evaporator becomes the condenser through a reverse valve. This is how the GSHP uses the ground as a heat source in heating mode and a heat sink in cooling mode. 


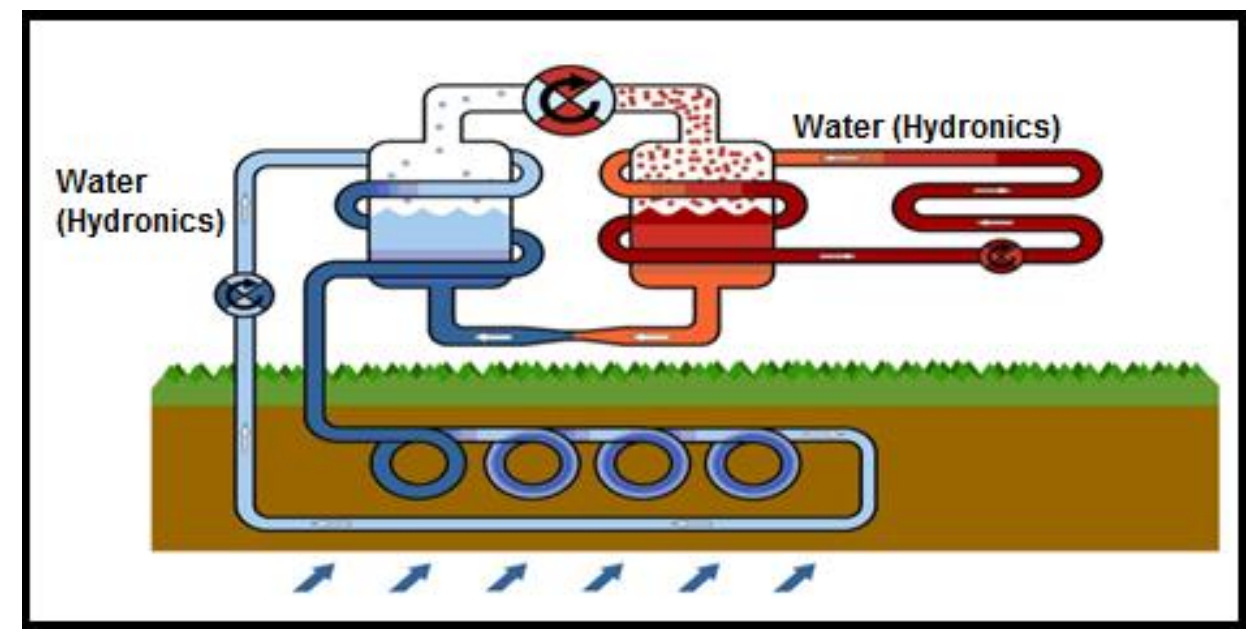

Figure 1.2 : Water-to-water heat pump (Inherent Energy, 2013)

A desuperheater, as illustrated in Figure 1.3, provides domestic hot water (DHW) when the compressor is operating. The desuperheater is a small auxiliary heat exchanger at the compressor outlet. It is used preferably in cooling mode to recover heat from the high pressure and high temperature refrigerant exiting the compressor. This process enhances heat pump efficiency because it allows the refrigerant to be further condensed at the condenser heat exchanger (NRCan, 2005). However, when used in heating mode, the heat used to heat the water is taken from the overall useful heat produced from the heat pump.

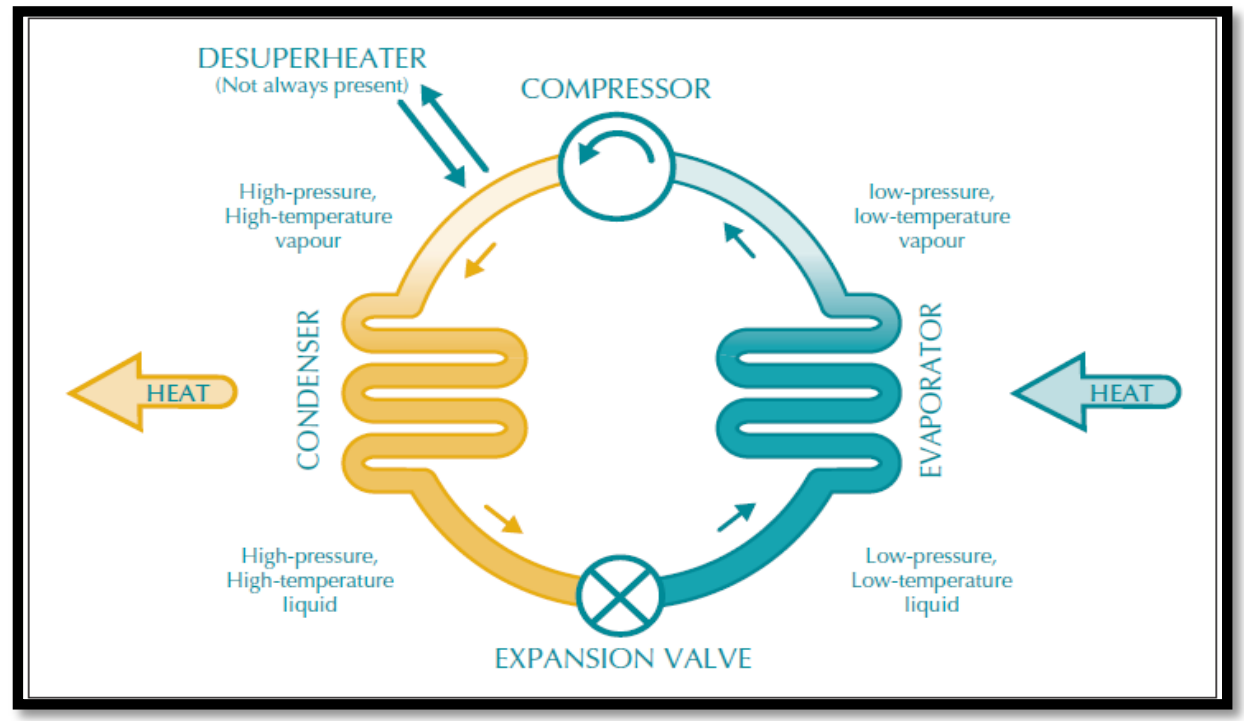

Figure 1.3 : The refrigeration cycle in heating mode of a typical heat pump unit (NRCan, 2005) 
The ground loop is where the heat transfer between the GSHP system and the soil occurs. The two most common types of ground loops are horizontal and vertical. In the horizontal loop configuration, pipes are buried in horizontal trenches, whereas in the vertical loop configuration, the pipes go into vertical boreholes.

Looking at the industry average in Canada over 2008-2010, 56.4\% of residential systems had a horizontal ground heat exchanger (GHE) and $24.2 \%$ had a vertical GHE. Open loop systems that use wells follow with $13 \%$ of residential applications while pond and lake loops account for $6.4 \%$. The higher popularity of the horizontal loop configuration is due to the lower price of installing a horizontal ground loop. In 2010 for example, the average vertical GSHP system sold for $\$ 7886$ per ton in Canada compared to $\$ 6116$ per ton for a GSHP system with a horizontal GHE. The total average price for a 4-ton system is $\$ 31,544$ for a GSHP system with a vertical GHE and \$24,464 for a system with a horizontal GHE. Horizontal systems are roughly $25 \%$ less expensive per ton than the vertical option (Canadian GeoExchange Coalition, 2011). Although the horizontal GHE may require more piping in some cases, there are significant savings made on trenching versus drilling.

This study was conducted in the Archetype Sustainable House (ASH) project at the Living City Campus at the Kortright Centre in Vaughan, Ontario, Canada. The twin houses are among the first Canadian projects to achieve LEED for Homes Platinum certification. House A demonstrates best practice technology and design available to home owners today while House B incorporates experimental technologies. ASH was developed by the Toronto and Region Conservation Authority (TRCA) along with the Building Industry and Land Development (BILD) Association. Those prototype twin houses are designed to demonstrate sustainable housing technologies in Ontario through research, education, training, market transformation and partnership programs (Dembo et al., 2009).

Amongst a variety of sustainable technologies within the twin houses, the House B ground source heat pump is the main focus in this thesis. The Archetype Sustainable House B provides a unique opportunity to compare two different ground loops systems under identical 
energy loads. House B has both vertical and horizontal loops that are connected to the same heat pump in the basement. Also, a long term monitoring system has been implemented to monitor the equipment and the loops using a data acquisition (DAQ) system, and analysed using the LabVIEW platform. Using this DAQ system, data from various sensors installed in the system are collected every 5 seconds (Zhang, Barua, \& Fung, 2011). Figure 1.4 shows the south-west elevation of the twin houses where House A is located on the west side and B on the east side neighbouring to the in-law suite.

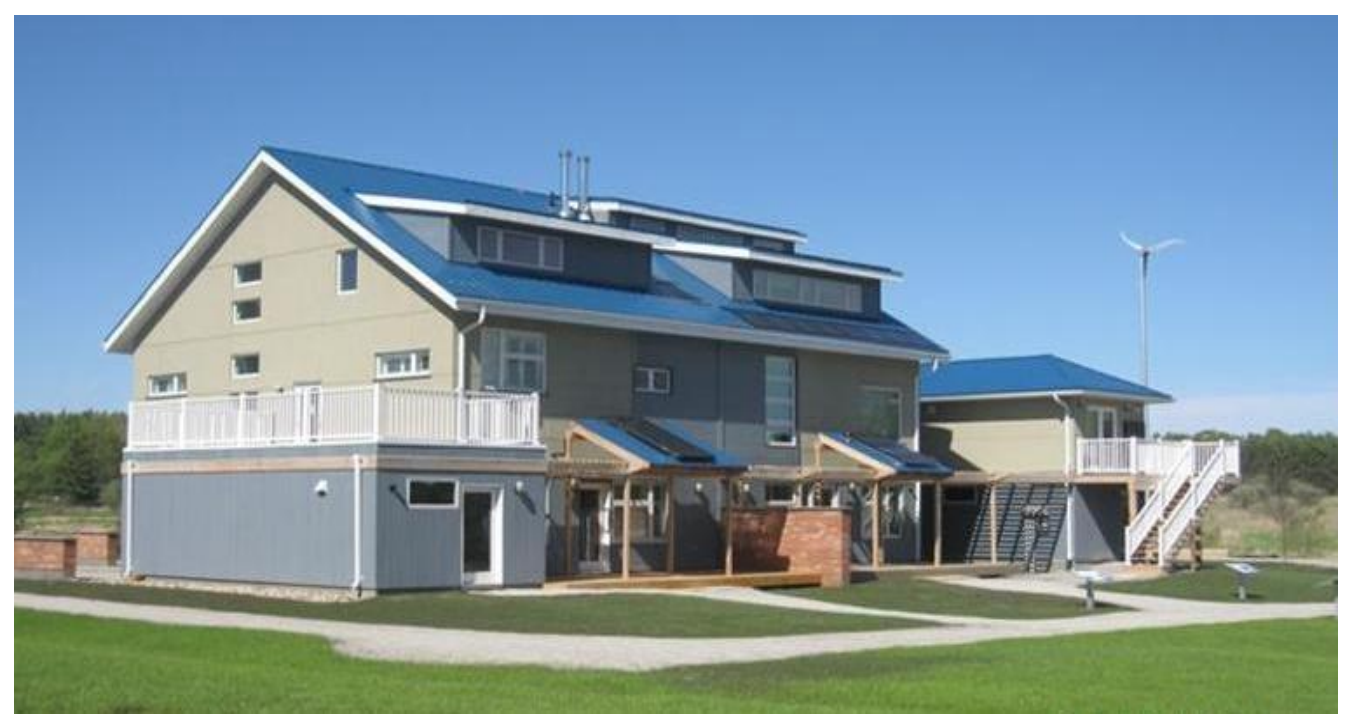

Figure 1.4 : South-west view of the Archetype Sustainable twin houses 


\section{CHAPTER 2}

\subsection{Literature Review}

A variety of methods have been used in the literature to investigate the performance of GSHP systems. In most cases, the GSHP is mainly composed of a compressor, an expansion valve, a condenser, an evaporator, and a ground loop heat exchanger. In rare cases, a direct expansion ground coupled heat pump is used. In the direct expansion ground coupled heat pump, the working fluid from the heat pump circulates in the ground loop directly which eliminates the need for a heat exchanger between the GSHP and the ground loop. The coefficient of performance (COP) is generally used in the literature to describe the performance of the tested systems. In heating mode, the COP is defined as the output thermal energy over the input electricity consumption.

A study has been conducted at the current experimental site at the Archetype Sustainable Twin houses located in Vaughan, Canada. The study was to evaluate the thermal performance of the GSHP using the horizontal loop. The GSHP COP was found to be 3.98 in the cooling mode while the heating mode COP was found to be 2.86. The GSHP COP calculations were based on the heating/cooling output and the power consumption of the GSHP compressor and the groundloop pumps without considering the GSHP/buffer-tank pump (Safa, 2012). The current study investigates the performance of the GSHP using the vertical loops and the combination of the horizontal and the vertical loops at the same time.

A similar and recent experimental comparison between a horizontal GSHP system and a vertical GSHP system was published focusing on the GSHP heating performance in Elazig, Turkey (Benli and Huseyin, 2013). The experimental comparison is the only study in the literature considering both a horizontal GSHP system and a vertical GSHP system side by side. The heating system consisted of two different ground heat exchangers, a heat pump, measuring units, and a heating space of a model-sized glass greenhouse with an area of $30 \mathrm{~m}^{2}$. The heating coefficients of performance of the two ground-source heat pumps were obtained in the range of 
3.1-3.6 for the horizontal GSHP, and 3.2-3.8 for the vertical GSHP, respectively. Also, the systems' overall heating coefficients of performance were obtained in the range of 2.7-3.3 for the horizontal GSHP system, and 2.9-3.5 for the vertical GSHP system, respectively. The aim was to demonstrate the technical and design feasibility of using GSHP systems in mild climate applications for greenhouse heating, where heating requirements are dominant. However, there have been no studies in the literature of the heating and cooling advantages of each system in residential buildings.

Another experimental study was done in Firat University, Elazig, Turkey in 2004 to evaluate the effects of the buried depth of two horizontal loops that were connected to a GSHP system (Inalli and Esen, 2004). The GSHP system was used for space heating of a test room with $16.24 \mathrm{~m}^{2}$ floor area. The GSHP system was connected to two horizontal ground loops, each with a 50-m pipe length, a $0.3-\mathrm{m}$ pipe spacing, a $0.016-\mathrm{m}$ nominal pipe diameter, and a $15-\mathrm{m}^{2}$ trench area. The two horizontal loops were buried in different trenches at $1 \mathrm{~m}$ and $2 \mathrm{~m}$ depths. The average heating $\mathrm{COP}$ of the system was found to be 2.66 using the 1-m deep horizontal loop and 2.81 for the 2-m horizontal loop. At both depths, the ground temperature was affected by the weather conditions but the deeper ground was at least $3^{\circ} \mathrm{C}$ warmer during the entire heating season.

Growing interest worldwide has driven more experimental work to take place to verify potential use of GSHP systems in developing countries. A study was carried out to investigate the cooling mode application of GSHP systems in Tunisia (Naili et al., 2013). As a result, a GSHP system using a horizontal Ground Heat Exchanger was installed and evaluated in the Research and Technology Center of Energy (CRTEn), Borj Cedria, Tunisia. The experiment was conducted in a test room with a floor area of about $12 \mathrm{~m}^{2}$. In the floor of the tested room was an integrated polyethylene exchanger (PEX) used as a radiant floor cooling (RFC) system. These experimental data were to evaluate the performance of the GSHP and the overall system in a continuous operation mode. The GSHP COP and overall system COP were found to be 4.25 and 2.88 , respectively. The results proved the suitability of the system and encouraged the use of GSHP systems for Tunisian building cooling. 
In China, an experimental evaluation of the heating performance of a direct expansion ground-coupled heat pump (DX-GCHP) was carried out in 2007-2008 (Wang et al., 2009). The DX-GCHP used R134a as the refrigerant and consisted of three single U-tube copper ground heat exchangers (GHEs) placed in three 30-m vertical boreholes. During the test period, the heat pump supplied hot water to a fan-coil unit at $50.4^{\circ} \mathrm{C}$, and its heating capacity was $6.43 \mathrm{~kW}$. The heating coefficient of performance of the heat pump and the whole system were found to be on average 3.55 and 3.28 at an evaporating temperature of $3.14^{\circ} \mathrm{C}$ and a condensing temperature of $53.4^{\circ} \mathrm{C}$, respectively.

An experimental study on the heating mode performance of a GSHP system was performed in the city of Erzurum, Turkey (Kara, 2007). The GSHP system used a vertical single U-tube ground heat exchanger. The loop was made of polyethylene pipe with a 16-mm inside diameter that was placed in a vertical borehole with 55-m depth and 203.2-mm diameter. The heat extraction rate per meter of the borehole was determined as $33.60 \mathrm{~W} / \mathrm{m}$. The average coefficients of performance of the GSHP system and heat pump in heating mode were 2.09 and 2.57, respectively. The low COP in this study was due to the oversized pumps which resulted in high pumping power consumption that was not needed. The study also showed that the thermal resistance of a borehole is strongly influenced by thermal properties of backfill material and circulation of surface water. As the permeability of the GHE backfill material was high, the refilled soil could not prevent the vertical circulation of surface water that decreases the thermal efficiency of GHE in heating mode.

The performance of a vertical ground-coupled heat pump system in a school building in Korea was evaluated. In the study, ten heat pump units with the capacity of $10 \mathrm{hp}$ each were installed in the school building with a closed vertical type ground heat exchanger with 24 boreholes of 175-m depth. The evaluation of the cooling performance was conducted under the actual operation of a GSHP system in the summer of 2007. A data acquisition system was used to monitor various operating conditions over the summer period. Those included the ambient temperature, the ground temperature, the water inlet and outlet temperatures of the ground heat exchanger, and the power consumption rate of the heat pump system. The findings of this study 
indicated that the overall cooling COP of the GSHP system was found to be 5.9 at a $65 \%$ partial load condition (Hwang et al., 2008). The same GSHP system was then tested and the results were published recently. In heating mode tests, the COP of the heat pump was 4.3-8.3 at partial load conditions, while the overall system COP is 3.0-6.2. From the measured data, the variation of ground temperature at $2.5 \mathrm{-m}$ and $5.0-\mathrm{m}$ depth were affected by outdoor air temperature. However, it was shown that the ground temperature was almost constant below $10 \mathrm{~m}$ in depth.

An experimental study on double U-tube borehole heat exchangers (BHEs) with three different vertical borehole diameters was carried out in Nuremberg, Germany (Luo et al., 2013). The BHE was constructed with 18 boreholes that were grouped into three blocks: block I of 121$\mathrm{mm}$ borehole diameter, block II of $165-\mathrm{mm}$ borehole diameter, and block III of 180-mm borehole diameter. The operation of the GSHP system was monitored between March 2009 and October 2012 for analysis. The thermal performance of BHEs was observed to be slightly improved for larger borehole diameters (block II and III). Using the recorded data, thermal exchange rates were calculated and compared in a daily period as well as a seasonal period. The daily statistics indicated that the thermal exchange rate of the BHE increases with larger borehole diameter. For the seasonal cooling performance, the amount of thermal exchange of BHEs with $165-\mathrm{mm}$ and 180-mm diameters was found to be $3.2 \%$ and $7.1 \%$ larger than that of the BHE with the 121-mm diameter, respectively. For the comparison among the three blocks, thermal load of block II was 1.64\% and block III was 3.45\% larger than that of block I, respectively. In addition, saving-to-investment ratio (SIR) was evaluated for two parts: the basic part (SIRI) for block I; the extra parts (SIRII-I, SIRIII-I) for block II and block III. Over a thirty-year period the SIR was estimated to be 4.80, 2.14 and 3.18 for SIRI, SIRII-I and SIRIII-I, respectively.

An experimental study of a solar-assisted ground-coupled heat pump system (SAGCHPS) with solar seasonal thermal storage was installed in a detached house in Harbin, Heilongjiang, China (Wang et al., 2010). The solar seasonal thermal storage was conducted throughout the non-heating seasons. In summer, the soil was used as the heat sink to cool the building directly. In winter, the solar energy was used as the main source of heating. Also, the building was heated by solar collectors and a vertical ground-coupled heat pump when needed. The results showed 
that the system met the heating-cooling energy needs of the building. In the heating mode, the heat directly supplied by solar collectors accounted for $49.7 \%$ of the total heating output, and the average coefficients of performance (COP) of the heat pump and the system were 4.29 and 6.55, respectively. The system's higher COP was a result of using the solar collectors. In the cooling mode, the COP of the system reached 21.35, as the heat pump was not necessary to be run. After a year of operation, the heat extracted from the soil by the heat pump accounted for $75.5 \%$ of the heat stored by solar seasonal thermal storage. The excess heat raised the soil temperature to a higher level, which was favorable for increasing the heating COP of the heat pump.

A three-year study on the performance of a GSHP system in Northern Greece was published in 2007. The GSHP system used a data acquisition system (DAQ) to collect data from sensors installed on the heat pump unit. The study looked at the basic parameters and the energy flows of a ground source heat pump system used for air conditioning of a City Hall building. The building is a public space with an air-conditioned area of $1350 \mathrm{~m}^{2}$. The ground source heat pump system consisted of 7 groups of water-to-water heat pumps, 21 boreholes with 80-m depth and fan-coil units. The basic operational characteristics were constantly monitored from January 2003 to December 2005. The data logging system monitored the ground heat exchanger inlet and outlet temperatures, and the ambient air temperature every 10 minutes. The results of the monitored system indicate that the primary energy required by the system for heating was estimated to be lowered by $45 \%$ and $97 \%$ (period average) as compared to that of an air-to-water heat pump based and a conventional oil boiler, respectively. Another important conclusion regarding the system operation was the changing trend of the seasonal COP. There was an increasing trend of the seasonal COP for heating, from 4.4 to 5.2 and a much less enhanced decreasing trend of the seasonal COP for cooling, from 4.5 to 4.4. The building cooling load was higher than the heating load and over the cyclic (heating-cooling) operation of the GSHP system over the three year period which imposed higher ground temperature. The ground temperature increase had a stronger influence on the heating mode rather than on the cooling mode, because of the average temperature level (Michopoulos et al., 2007). A more recent publication on the operation characteristics of the same system over an eight-year period is available (Michopoulos et al., 2013). Due to the longer cyclic (heating-cooling) operation of the GSHP system over the 
eight-year period, the ground temperature was even higher than in the last study. It was found that the maximum ground heat exchanger load was $50 \mathrm{~W} / \mathrm{m}$ in heating operation while in cooling mode it ranged between 20 and $210 \mathrm{~W} / \mathrm{m}$. Compared to a conventional heating and cooling system for the building, the ground source heat pump consumed $25.7 \%$ less primary energy. Using emission factors for the combustion of diesel fuel and for electricity production, the amounts of carbon dioxide $\left(\mathrm{CO}_{2}\right)$, and nitrogen oxides $\left(\mathrm{NO}_{\mathrm{x}}\right)$ emissions were calculated. The ground source heat pump emits less $\mathrm{CO}_{2}$ and $\mathrm{NO}_{\mathrm{x}}$ by $22.7 \%$ and $99.6 \%$ respectively.

Growing interest in Japan has driven more experimental studies to verify potential use of GSHP systems in different regions. A study of field data examining the long-term performance and environmental effects of a large GSHP system in cold regions was done in the city of Akabira in the north of Hokkaido, Japan (Li et al., 2013). The GSHP used a large vertical ground loop system to provide heating and cooling for 12 greenhouses. The system had a maximum capacity of 640 and $648 \mathrm{~kW}$ for heating and cooling, respectively. The system was monitored and analyzed from October 2010 through May 2011. The GSHP had a COP of 3.0 and an overall system COP of 2.7. The average heat extraction rate of the system was approximately $27.7 \mathrm{~W} / \mathrm{m}$. In addition, the ground temperature at a depth of $40 \mathrm{~m}$ decreased from approximately $7.8^{\circ} \mathrm{C}$ to $0^{\circ} \mathrm{C}$ after 8 months of operation. $\mathrm{CO}_{2}$ emission in the heating mode was calculated to be $20 \%$ and 22\% lower than those of Air Source Heat Pump (ASHP) and kerosene systems.

A system was designed and installed in the Solar Energy Institute, Ege University, Izmir, Turkey (Ozgener and Hepbasli, 2005). The system was investigated for performance characteristics of a Solar-Assisted Ground-Source Heat Pump System (SAGSHPS) for greenhouse heating with a 50-m vertical 32-mm nominal diameter U-bend ground heatexchanger. Based upon the measurements made in the heating mode from the 20th of January until the 31st of March 2004, the heat extraction rate from the soil was found to be, on average, $57.78 \mathrm{~W} / \mathrm{m}$ of bore depth, while the required borehole length in metre per kilowatt of capacity is obtained as 11.92 . The entering water temperature to the unit ranged from $8.2^{\circ} \mathrm{C}$ to $16.2^{\circ} \mathrm{C}$, with an average value of $14^{\circ} \mathrm{C}$. The heating coefficient of performance of the heat pump was 2.00 at 
the end of a cloudy day, while it was 3.13 at the end of sunny day and fluctuated between these values in other times.

The effective thermal conductivity of six vertical closed-loop ground heat exchangers (GHEs), which were installed in a test bed located in Wonju, South Korea, has been experimentally evaluated by performing in-Situ thermal response tests (TRTs) (Lee et al., 2012). To compare the thermal efficiency of the GHEs in field, various installation conditions were considered such as different grouting materials (cement vs. bentonite), different additives (silica sand vs. graphite) and shapes of the circulating pipe-section (conventional U-loop type vs. 3-pipe type). The 3-pipe type is a conventional U-loop with a central pipe that is filled with water to reduce thermal interference between the inlet and outlet pipes. From the test results, it was concluded that the cement grout had higher effective thermal conductivity than the bentonite grout by $7.4-10.1 \%$, and the graphite outperformed the silica sand by $6.7-9.1 \%$ as a thermallyenhancing additive. In addition, the new 3-pipe type heat exchanger resulted in less thermal interference between the inlet and outlet pipes and showed better thermal performance over the conventional U-loop type heat exchange pipe by 14.1-14.5\%. For the same conditions, the cement grouting could reduce the construction cost of GHEs by around $40 \%$ in the cost analysis scenario. Also, addition of graphite and use of the new 3-pipe heat exchanger led to about $8 \%$ and $6 \%$ operation cost reduction, respectively. The addition of graphite significantly increased the thermal conductivity of the cement grout.

A reversible ground source heat pump was installed and tested at the Eco House, University of Nottingham, Nottingham, United Kingdom (Doherty et al., 2004). The system was tested with various ground loop configurations. The GSHP was installed in the house to provide heating and cooling, and a natural gas-fired condensing boiler was added to provide supplementary heating when required. The heat pump unit had a heating capacity of $8 \mathrm{~kW}$ using R-22 as the refrigerant and included a desuperheater to provide hot water at low flow rates. The results of the test indicated that the difference between the entering water temperature to the evaporator and the exiting temperature of the condenser significantly affected the heat pump COP. In heating mode the COP was obtained to be 3.5 at a $30^{\circ} \mathrm{C}$ difference in entering source 
temperature and an exit load temperature, while the COP was obtained to be 3 at a $40^{\circ} \mathrm{C}$ difference between entering source temperature and an exit load temperature.

The performance of a GSHP with a vertical ground heat exchanger was investigated experimentally using monitored data from a data acquisition system in Erzurum, Turkey (Bakirci, 2010). The experimental results were obtained from October to May for the months of the heating season of 2008-2009. The system consisted of an $8 \mathrm{~kW}$ heating capacity heat pump with a single U-tube placed in two vertical boreholes that were $53 \mathrm{~m}$ deep. The ground loop fluid consisted of $50 \%$ antifreeze-water mixture while refrigerant $134 \mathrm{a}$ was used as the working fluid in the heat pump. The findings of the experimental study indicated that at an average entering source temperature of $1.6^{\circ} \mathrm{C}$ and an entering load temperature of $47^{\circ} \mathrm{C}$ the average heating COP was obtained to be 2.89. The results also showed that the average heat-pump COP and overall system's COP values were approximately 3.0 and 2.6 in the coldest months of the heating season.

The effect of cyclic operation of a horizontal ground loop coupled heat pump performance was studied using a finite element numerical model (Wibbels \& Braven, 1994). The results showed that cyclic operation would decrease the performance of the heat pump. It was also shown that as the pipe radius is increased, the effect of cyclic operation decreases due to the fluid capacity.

As evident from the literature, there have been some studies that experimentally investigate GSHP performance when coupled to a vertical or a horizontal ground loop. However, there still remain some potential improvements and gaps in this area of research that will be addressed in this study. For instance, testing the two different ground loops systems under similar conditions is uncommon in the literature. The only study that tested the two systems side by side focused only on using GSHP systems for greenhouse heating in mild climate. Most of GSHP systems in the literature investigated either the horizontal or the vertical loop configurations and fail to provide a good understanding of the GSHP performance when using both loops in a residential building. The Archetype Sustainable House B provides a unique opportunity to 
compare two different ground loops systems under identical energy loads. Both configurations are tested and investigated simultaneously in the same location, allowing a direct comparison of performance.

\subsection{Objectives}

In order to evaluate the benefits from the two vertical and two horizontal ground loops and the GSHP system, it is necessary to carry out comprehensive monitoring on every aspect of the performance of the system. The specific objectives of the study are listed below:

- Design and execution of the ground loops flow control system.

- Replacement of the ground loop fluid with the optimum concentration of water/PG solution for the loops.

- Experimental setup of all the necessary sensors, sensors locations and the data acquisition system to carry out the experiment.

- Installation of all the sensors.

- Calibration of all the sensors.

- Implementation of the Data Acquisition (DAQ) system.

- Validating the collected data from all related sensors, through cross-checking and performing calibration, when required.

- Regular monitoring and backup of the database to insure the quality of the data collected during the test.

- Analyzing the data obtained, evaluating the effectiveness and performance of the components, and cross checking them with the manufacturers' data.

- Further analysis during the experiment to investigate the issues with the as-built system when discovered.

- Compare the performance of each loop and identify the factors that influence the GSHP performance. 


\section{CHAPTER 3}

\section{House and Systems Description}

Constructed in the summer of 2008, the Archetype Sustainable House consists of two semi-detached houses designed to serve as a model or prototype for the next generation of "green" production homes. The Archetype Sustainable House provides education and opportunities for research on renewable energy, energy efficiency, wastewater treatment and sustainable building design. The houses, referred to as House A and House B, are one of the first Canadian projects to achieve a LEED (Leadership in Energy and Environmental Design) Platinum Certification and they both meet Natural Resources Canada (NRCan) R2000 Standard (Dembo et al., 2010). The twin houses are located at the Living City Campus at Kortright Centre in the City of Vaughan, Ontario, as shown in Figure 3.1.

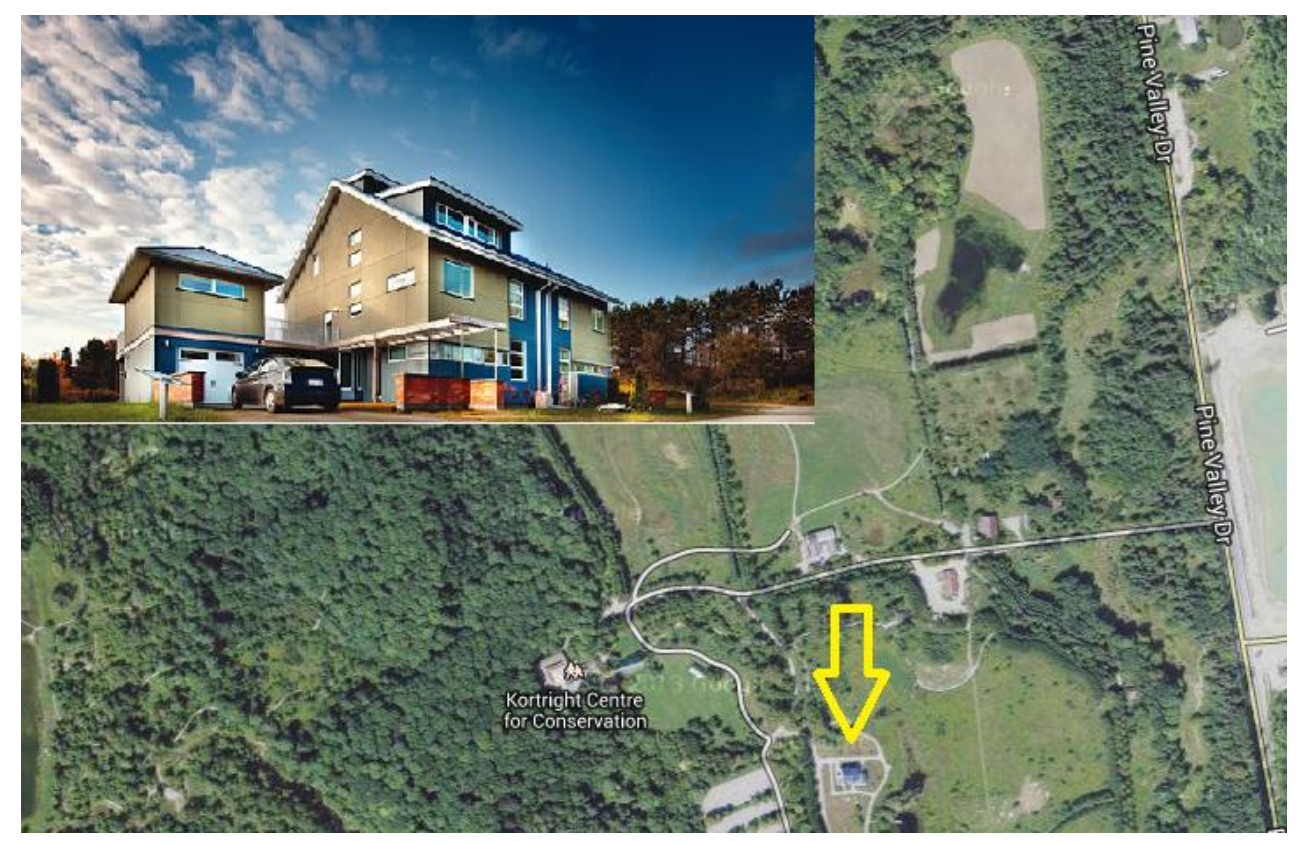

Figure 3.1 : Location of the twin houses at The Living City Campus at Kortright Centre (Latitude $=$ $43.8317^{\circ}$, Longitude $=-\mathbf{7 9 . 5 8 9 6}^{\circ}$ ).

It is approximately $25 \mathrm{~km}$ north of Lake Ontario. Table 3.1 provides climate statistics for the area, based on 30 years of data collected at a North York weather station, roughly $10 \mathrm{~km}$ 
southeast of the site (Pelmorex Media, 2013). The intent of House A is to demonstrate current best practice sustainable technologies while the second, House $\mathrm{B}$, is designed to demonstrate experimental sustainable technologies for the future. In this study, the focus will be on the GSHP system, House B, and the two ground loop systems.

Table 3.1 : Climate statistics for the site, North York weather station (Pelmorex Media, 2013)

\begin{tabular}{|c|c|c|c|c|c|c|c|c|c|c|c|c|}
\hline & JAN & FEB & MAR & APR & MAY & JUN & JUL & AUG & SEP & OCT & NOV & DEC \\
\hline Average high $\left({ }^{\circ} \mathbf{C}\right)$ & -1.2 & 0.8 & 5.6 & 11.4 & 19.3 & 24.8 & 26.9 & 26 & 21.8 & 14.8 & 6.9 & 1.7 \\
\hline Average low $\left({ }^{\circ} \mathbf{C}\right)$ & -9 & -7.4 & -3.8 & 1 & 7.8 & 13.6 & 15.6 & 15 & 10.8 & 5.2 & -0.2 & -5.3 \\
\hline Average $\left({ }^{\circ} \mathbf{C}\right)$ & -5.1 & -3.3 & 0.9 & 6.2 & 13.5 & 19.2 & 21.3 & 20.5 & 16.3 & 10 & 3.4 & -1.8 \\
\hline Cooling degree days $\left({ }^{\circ} \mathrm{C}\right.$-days $)$ & 0 & 0 & 0 & 0 & 14 & 66 & 109 & 87 & 29 & 1 & 0 & 0 \\
\hline Heating degree day $\left({ }^{\circ} \mathrm{C}\right.$-days $)$ & 716 & 605 & 532 & 354 & 152 & 30 & 8 & 9 & 81 & 248 & 438 & 615 \\
\hline Monthly rainfall (mm) & 50 & 30 & 26 & 62 & 87 & 100 & 73 & 72 & 84 & 59 & 58 & 32 \\
\hline Monthly snowfall (cm) & 39 & 15 & 26 & 6 & 0 & 0 & 0 & 0 & 0 & 0 & 11 & 28 \\
\hline
\end{tabular}

\subsection{House B Description}

House B has a high level of integration between its various components. It uses the geothermal ground loops as both a heat source and heat sink. By integrating the geothermal system with the radiant floors and ventilation system, House B can regulate its temperature efficiently. The geothermal system can also provide DHW when needed. In addition, hot or chilled water is delivered to the in-law suite AHU from the geothermal system to provide heating or cooling. The in-law suite is used as a small office space that was built above the garage of House B. The basic design features of the house are listed in Table 3.2. Table 3.3 lists the structural features of House B whereas Table 3.4 lists the floor areas and volumes (Barua, 2010). 
Table 3.2 : Basic design features of House-B (Zhang et al., 2011)

\begin{tabular}{|l|c|}
\hline Features & House-B \\
\hline Orientation & South facing \\
\hline Stories & 3 \\
\hline Floor & $232 \mathrm{~m}^{2} / 25^{\prime} \times 40^{\prime}\left(2500 \mathrm{ft}^{2}\right)$ \\
\hline Natural Infiltration & $0.06 \mathrm{ACH}$ \\
\hline Winter design conditions & $\begin{array}{c}\text { Outdoor temp: }-22^{\circ} \mathrm{C} /-7.6^{\circ} \mathrm{F} \\
\text { Indoor temp: } 22^{\circ} \mathrm{C} / 71.6^{\circ} \mathrm{F}\end{array}$ \\
\hline Summer design conditions & $\begin{array}{l}\text { Outdoor DB: } 31^{\circ} \mathrm{C} / 87.8^{\circ} \mathrm{F} \\
\text { Outdoor WB: } 24^{\circ} \mathrm{C} / 75.2^{\circ} \mathrm{F} \\
\text { Indoor temp: } 26^{\circ} \mathrm{C} / 78.8^{\circ} \mathrm{F}\end{array}$ \\
\hline Heating load & $7.94 \mathrm{~kW} / 27.1 \mathrm{MBH}$ \\
\hline Cooling load & $6.18 \mathrm{~kW} / 21.1 \mathrm{MBH}$ \\
\hline Ventilation & $70.79 \mathrm{Liters} / \mathrm{sec}(150 \mathrm{CFM})$ \\
\hline
\end{tabular}

Table 3.3 : Structural features of House B (Barua, 2010)

\begin{tabular}{|l|c|}
\hline Features & House-B \\
\hline Basement walls & RSI 3.54 (R20) \\
\hline Basement Slab & RSI 1.76 (R10) \\
\hline Above Grade Walls & RSI 5.64 (R32) \\
\hline Roof & RSI 7 (R40) \\
\hline Windows & Triple glazed, low "E", argon filled. U-value : $1.59 \mathrm{~W} / \mathrm{m}^{2} \mathrm{~K}\left(0.28 \mathrm{Btu} / \mathrm{hr} \mathrm{ft}^{2}{ }^{\circ} \mathrm{F}\right)$ \\
\hline Overall UA Value & $172 \mathrm{~W} / \mathrm{K} *$ based on TRNSYS House model $($ Safa, 2012). \\
\hline Wall insulation & Heat-lock Soya Polyurethane Foam and Icynene spray foam \\
\hline
\end{tabular}

Table 3.4 : Floor area and volume of House B (Barua, 2010)

\begin{tabular}{|l|c|c|}
\hline Floor Area & Area $-\mathrm{m}^{2}\left(\mathrm{ft}^{2}\right)$ & Volume $-\mathrm{m}^{3}\left(\mathrm{ft}^{3}\right)$ \\
\hline Basement & $86.95(936)$ & $234.03(8264)$ \\
\hline First Floor & $86.95(936)$ & $291.54(10296)$ \\
\hline Second Floor & $60.19(636)$ & $238.53(8424)$ \\
\hline Third Floor & $86.95(936)$ & $271.83(9600)$ \\
\hline Total & $321.04(3444)$ & $1035.94(36584)$ \\
\hline
\end{tabular}




\subsection{Mechanical Systems}

House B has many mechanical systems but the focus will be on the GSHP system and the other mechanical systems that are connected to it. Figure 3.2 shows the advanced HVAC systems in the house and the monitoring points. House B uses both horizontal and vertical loops connected to the GSHP with an optional desuperheater for water heating. The GSHP provides hot water to the buffer tank and from the buffer tank to the radiant in-floor systems in each floor when heating is called for. In the cooling season, the GSHP supplies chilled water to the buffer tank and then to the multi-zone AHU in House B and to the in-law AHU. The buffer tank is used in between the GSHP and the in-floor system/AHUs to minimize short cycling. Also, an energy recovery ventilator (ERV) was installed in the mechanical ventilation system as shown in Figure 3.2 .

A two-tank system was adopted for DHW production. One is a preheat tank that heats water using solar collectors and the other is a time-of-use (TOU) electric backup tank. The TOU tank is connected to the desuperheater of the GSHP to supply hot water. The TOU has two electric coils for hot water generation as a backup. The technical information on the heat pump systems and the other units are given in Table 3.5, while the equipment manufacturers and models are given in Table 3.6 (Barua, 2010). 


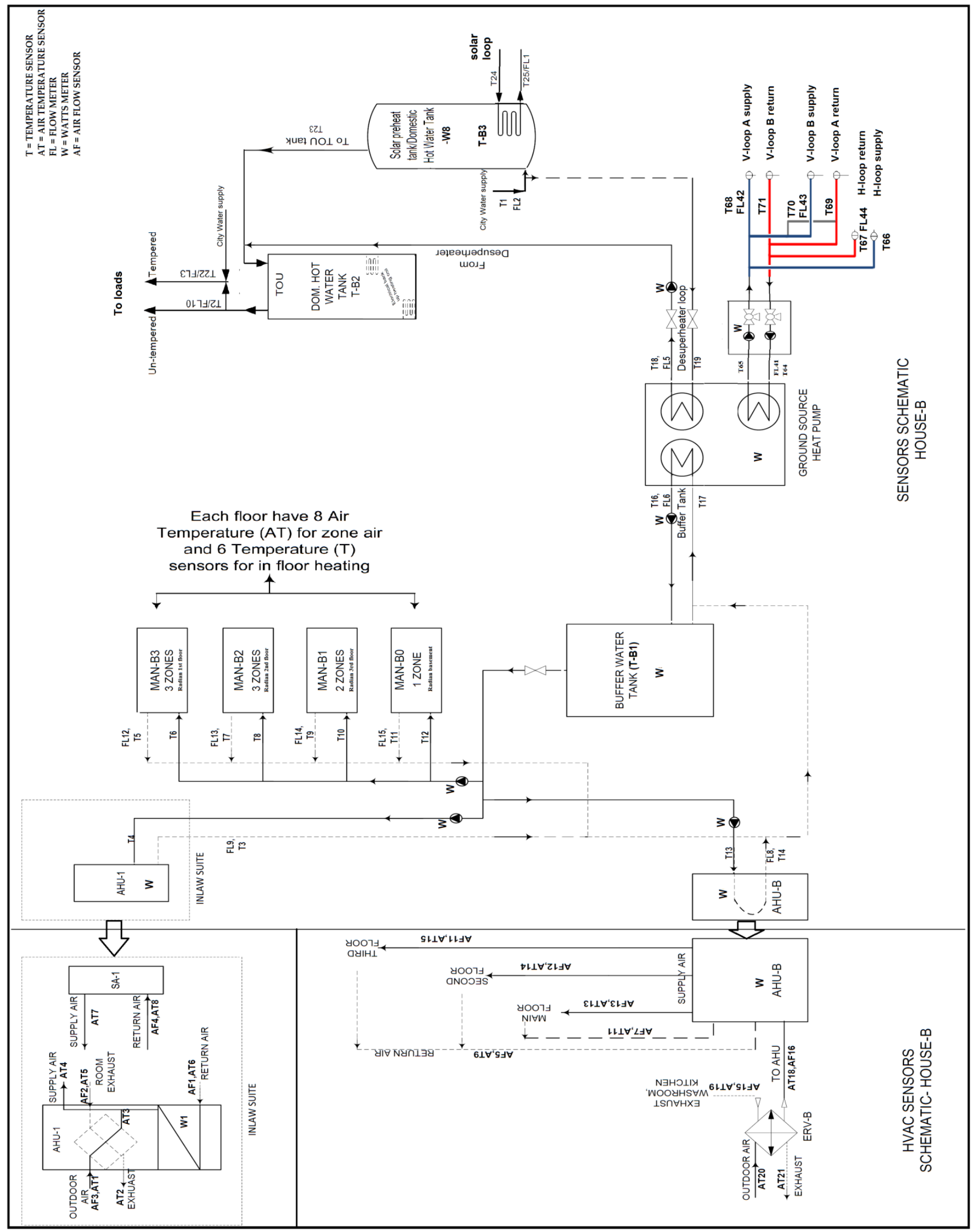

Figure 3.2 : Layout of HVAC system and monitoring points in House-B and in-law suite 
Table 3.5 : Mechanical system technical information (Safa, 2012)

\begin{tabular}{|c|c|}
\hline Equipment & Technical Information \\
\hline $\begin{array}{l}\text { Ground Source Heat } \\
\text { Pump (GSHP) }\end{array}$ & $\begin{array}{l}\text { HEATING CAPACITIES : } \\
\mathrm{COP}: 3.05 \text { (at an ELT of } 44.4^{\circ} \mathrm{C} \text { and an EST of } 2.7^{\circ} \mathrm{C} \text { ) to } 3.44 \text { (at an ELT of } \\
41.5^{\circ} \mathrm{C} \text { and an EST of } 5.48^{\circ} \mathrm{C} \text { ) } \\
\text { COOLING CAPACITIES : } \\
\text { COP : } 4.9 \text { (at an ELT of } 8.5^{\circ} \mathrm{C} \text { and EST of } 19.2^{\circ} \mathrm{C} \text { ) to } 5.6 \text { (at an ELT of } 12.4^{\circ} \mathrm{C} \\
\text { and EST of } 17.8^{\circ} \mathrm{C} \text { ) }\end{array}$ \\
\hline $\begin{array}{l}\text { Air Handling Unit } \\
\text { (House B) AHU-B }\end{array}$ & $\begin{array}{l}\text { Multi-Zone Air Distribution, Multi Speed Fan } \\
\text { Cooling capacity : } 12.3 \mathrm{~kW}(3.5 \text { tons }) \\
\text { Heating capacity : } 28 \mathrm{~kW}(95 \mathrm{MBH}) \\
\text { Nominal air flow rate }: 660 \text { Litres/sec }(1400 \mathrm{CFM})\end{array}$ \\
\hline $\begin{array}{l}\text { Air Handler Unit } \\
\text { (In-law suite) AHU-1 }\end{array}$ & Single zone maximum air flow : $212.25 \mathrm{~L} / \mathrm{s}$ (450 CFM) \\
\hline Buffer Tank T-B1 & 270 litres (71 USG) \\
\hline DHW TOU Tank T-B2 & Capacity: 175 Litres (50 USG), Maximum heating capacity: 6 kW (20 MBH) \\
\hline $\begin{array}{l}\text { Hot Water Tank } \\
\text { (preheat tank) T-B3 }\end{array}$ & Capacity: 300 Litres (79 USG) \\
\hline $\begin{array}{l}\text { Energy Recovery } \\
\text { Ventilator (ERV-B) }\end{array}$ & $\begin{array}{l}\text { Surface area: } 14.51 \mathrm{~m}^{2}\left(156 \mathrm{ft}^{2}\right) \text {, } \\
\text { Heating capacity: at }-15^{\circ} \mathrm{C}\left(5^{\circ} \mathrm{F}\right) \text { supply air temperature } \\
\text { Sensible recovery efficiency: } 55 \% \text {, } \\
\text { Latent recovery moisture transfer: } 0.26 \text {, } \\
\text { Net air flow rate: } 52 \mathrm{Litre} / \mathrm{sec}(110 \mathrm{CFM}) \\
\text { Cooling capacity: at } 35^{\circ} \mathrm{C}\left(95^{\circ} \mathrm{F}\right) \text { supply air temperature } \\
\text { Total recovery efficiency: } 41 \% \text {, } \\
\text { Net air flow rate: } 50 \text { Litres } / \mathrm{sec}(106 \mathrm{CFM})\end{array}$ \\
\hline
\end{tabular}

Table 3.6 : Manufacturer and model of equipment (Barua, 2010)

\begin{tabular}{|l|l|l|}
\hline Equipment & Manufacturer/Distributor & Model \\
\hline Ground Source Heat Pump & Water Furnace International, Inc. & EW 042 R12SSA \\
\hline AHU-B & Ecologix Heating Technologies Inc. & C3-06 \\
\hline Air handler \& HRV unit (In-law suite) & Nu-Air Ventilation Systems Inc. & Enerboss-400C \\
\hline Buffer Tank & GSW Water Heating & CST-80 \\
\hline DHW tank (TOU Tank)T-B2 & GSW Water Heating & 6G50SDE1 \\
\hline Hot water tank (preheat tank) T-B3 & VIESSMANN Manufacturing Inc. & VITOCELL-B 100 \\
\hline Energy recovery ventilator (ERV) & Venmar Ventilation Inc. & VanEE 45808 \\
\hline
\end{tabular}




\subsection{Ground loop systems}

The house has a closed ground loops system that is connected to the GSHP. This system consists of two horizontal loops and two vertical loops. The loops are connected to the GSHP as shown in Figure 3.3. This connection allows the GSHP to operate in different scenarios and controls the flow in each loop by controlling 7 valves as shown in Figure 3.4.

- Both the vertical loops in parallel (Figure 3.4.a).

- Both the horizontal loops in parallel (Figure 3.4.b).

- Both the horizontal loops and the vertical loops at the same time in parallel (Figure 3.4.c).

- Both the vertical loops in series.

- One vertical loop.

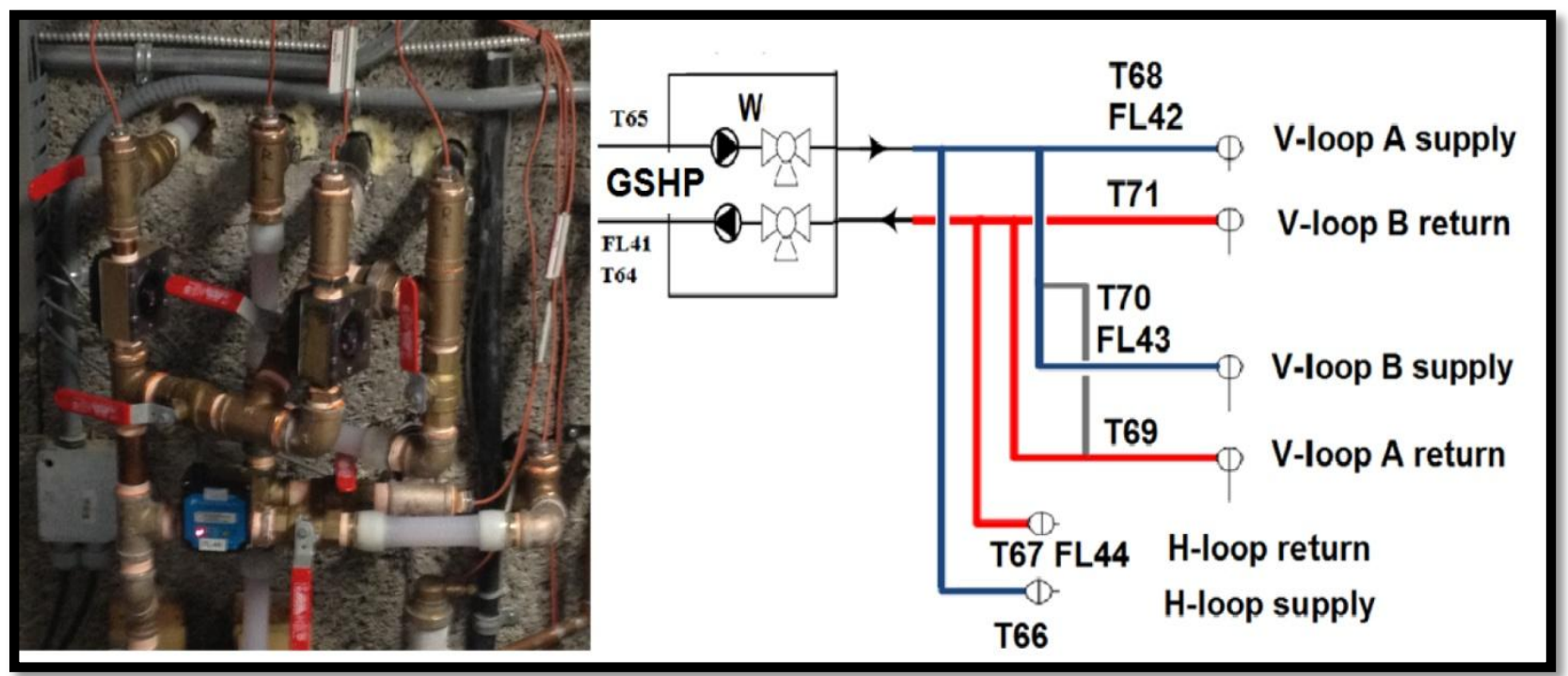

Figure 3.3 : The loops' connection to the GSHP 


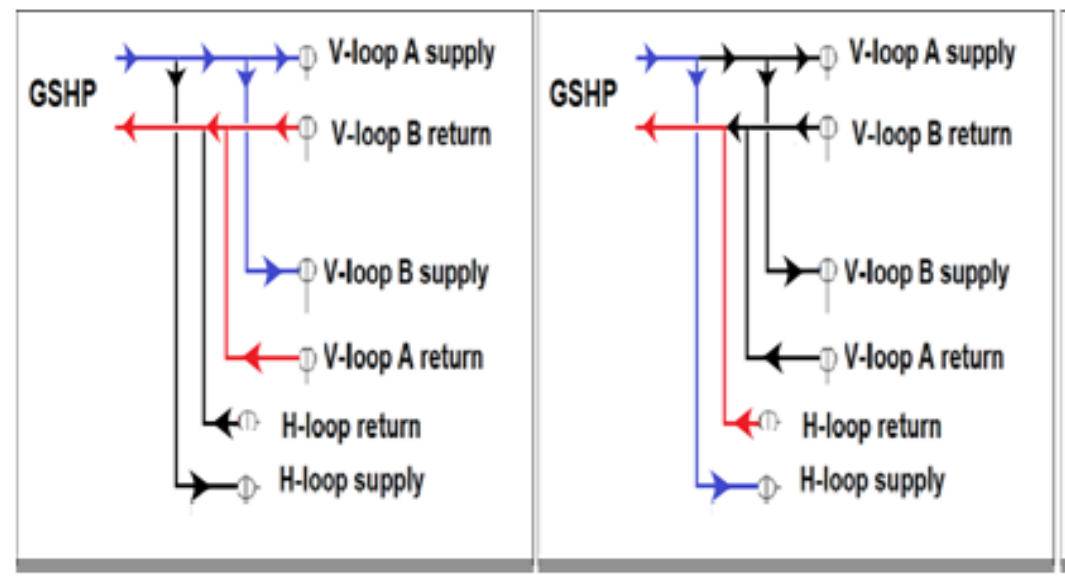

(a) (b)

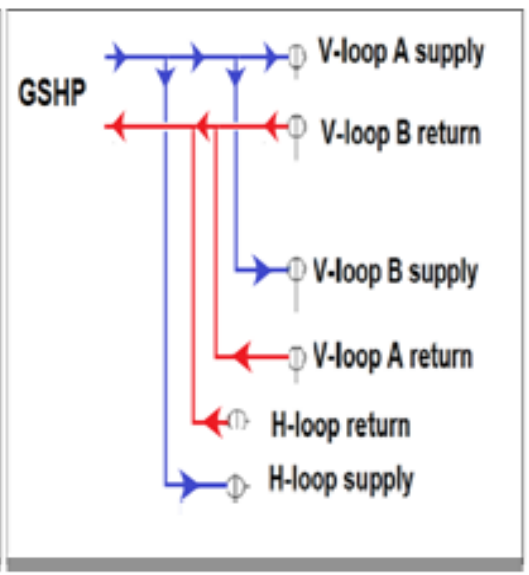

(c)

Figure 3.4 : Flow control diagrams (Blue: supply, Red: return, Black: no flow)

The reason for not being able to run more scenarios with the horizontal loops is that the two horizontal loops are connected in parallel in the field and a common connection is coupled to the flow control system in the house as seen in Figures 3.3 and 3.5. The loop specifications and details are listed in Table 3.7 and Figure 3.5.

Table 3.7 : The loop specifications and details

\begin{tabular}{|c|c|c|}
\hline & Vertical loops & Horizontal loops \\
\hline $\begin{array}{l}\text { Technical } \\
\text { Information }\end{array}$ & $\begin{array}{l}\text { Number of loops: } \mathbf{2} \\
\text { Depth of each loop: } \mathbf{7 6 . 2} \mathbf{m}(\mathbf{2 5 0} \mathbf{f t}) \\
\text { Total Length of each loop: } \mathbf{1 5 2 m}(\mathbf{5 0 0} \mathrm{ft}) \\
\text { Nominal Diameter: 1" } \\
\text { Average Inside Diameter: 1.06" } \\
\text { Average Outside Diameter: 1.315" } \\
\text { Min wall thickness: } 0.12 " \\
\text { Material: HDPE } 4710 \\
\text { Total volume of both loops: } 193 \text { L (51 US gal) }\end{array}$ & $\begin{array}{l}\text { Number of loops: } \mathbf{2} \\
\text { Depth of each loop: } \mathbf{1 . 8 3 m}(\mathbf{6} \mathbf{f t}) \\
\text { Total Length of each loop: } 366 \mathbf{~ m ~ ( 1 2 0 0 ~ f t ) ~} \\
\text { Nominal Diameter: 1.25" } \\
\text { Average Inside Diameter: 1.34" } \\
\text { Average Outside Diameter: 1.66" } \\
\text { Min wall thickness: } 0.15 " \\
\text { Material: HDPE } 3408 \\
\text { Total volume of both loops: } 732 \text { L (193US gal) }\end{array}$ \\
\hline Installed by & GeoEnergy Solutions Inc. & Geothermal Solutions \\
\hline Shape & U-loop & J-loop \\
\hline Fluid & \multicolumn{2}{|c|}{$20 \%$ propylene glycol $(\mathrm{PG})$ and $80 \%$ water with freezing point of $-8^{\circ} \mathrm{C}$} \\
\hline
\end{tabular}




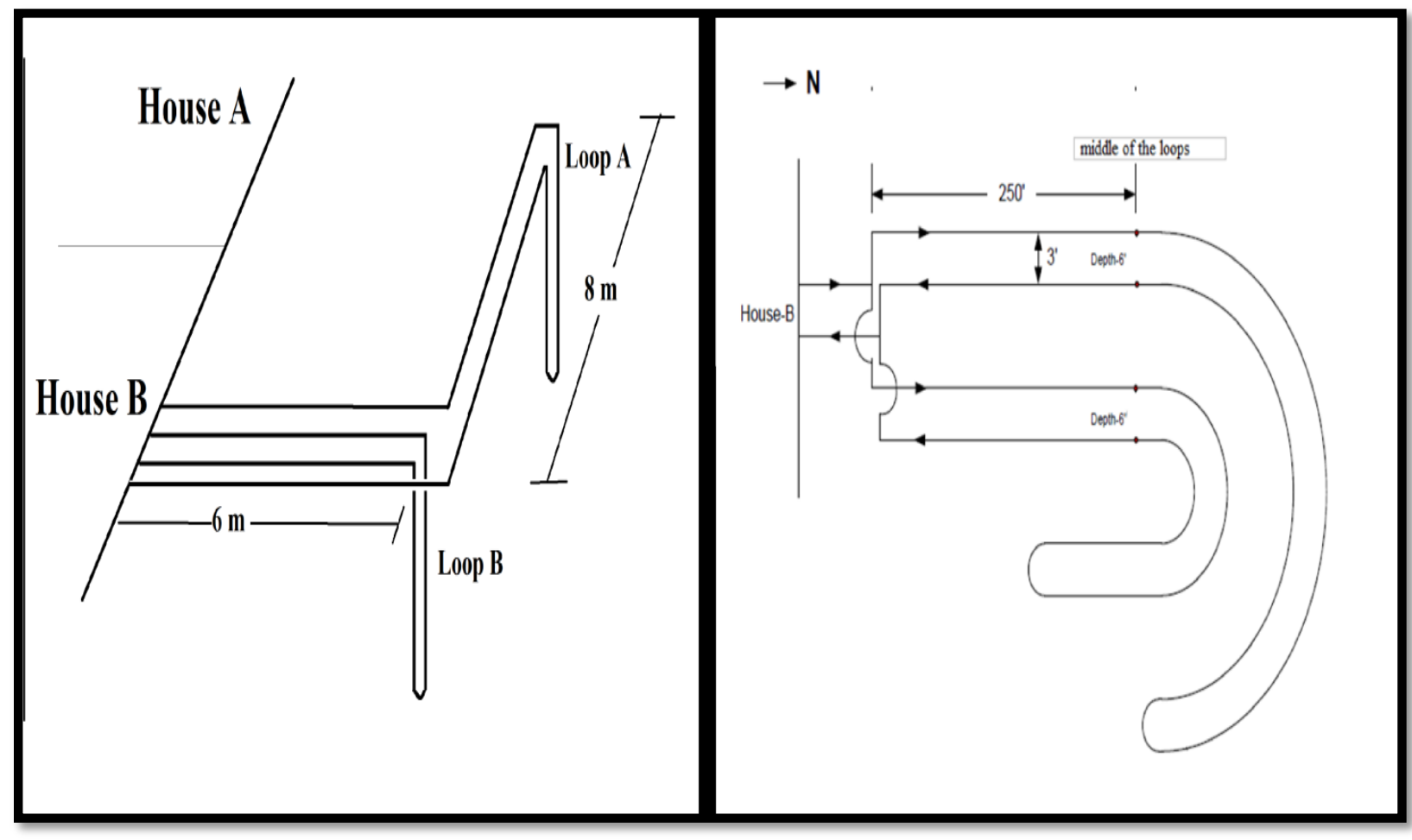

Figure 3.5 : The vertical loops configuration (left) and the horizontal loops configuration (right)

GeoEnergy Solutions Inc., which donated the two vertical closed loop boreholes for the Archetype Sustainable House at the Kortright Centre in Vaughan in 2011, was retained by the Toronto and Region Conservation Authority to drill a geothermal test borehole and conduct an in-situ thermal conductivity test for the Kortright's Visitor Centre. The test borehole was drilled to a total depth of $164.6 \mathrm{~m}$ at a location less than $200 \mathrm{~m}$ from House B vertical loops as shown in Figure 3.6. A geological log of the test borehole is included in Figure 3.7. The pre-test monitoring (before the heat injection) indicated that the deep earth temperature in the test borehole was $10.1^{\circ} \mathrm{C}$ and that the water table at the site is estimated to be approximately $5 \mathrm{~m}$ below the surface. The test involved the injection of a constant source of heat into the U-loop and the measurement of the changes in the temperature of the circulating fluid over a 48 -hour test period. A summary of the test and the results is given in Table 3.8 (GeoEnergy, 2011). 


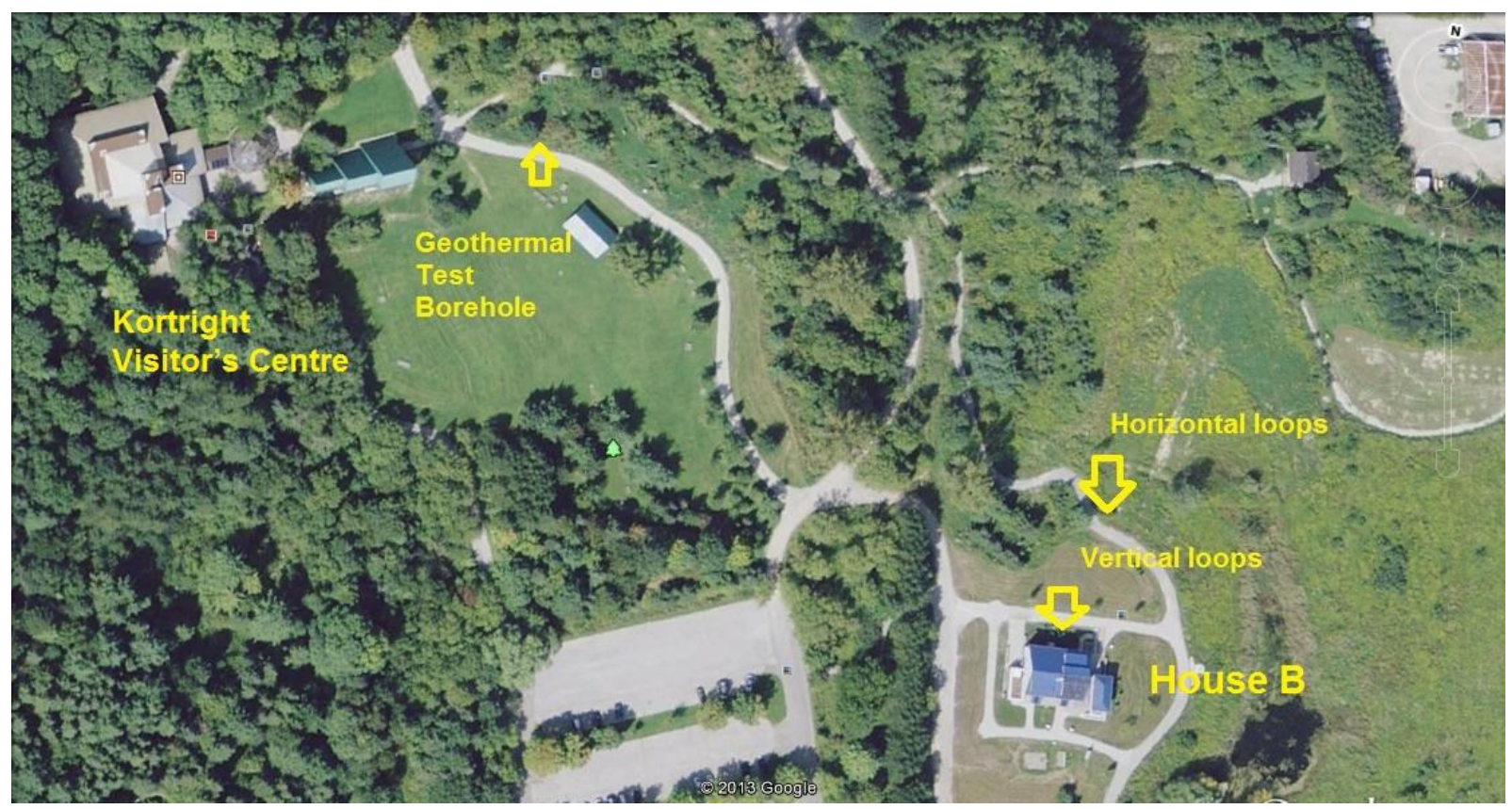

Figure 3.6 : Locations of the loops and test borehole

Table 3.8 : Summary of the thermal conductivity test and the results (GeoEnergy, 2011)

\begin{tabular}{|l|c|}
\cline { 2 - 2 } \multicolumn{1}{l|}{} & Value \\
\hline Power Input & $7355 \mathrm{~W}$ \\
\hline Flow Rate & $0.4 \mathrm{~L} / \mathrm{s}$ \\
\hline Deep Earth Temperature & $10 .{ }^{\circ} \mathrm{C}$ \\
\hline Static Water Level & $5.0 \mathrm{~m}$ below ground $($ Estimated $)$ \\
\hline Average Difference Between Supply and Return & $4.5^{\circ} \mathrm{C}$ \\
\hline Calculated Thermal Conductivity & $\lambda=2.45 \mathrm{~W} / \mathrm{m} \cdot \mathrm{K}\left(1.41 \mathrm{BTU} /\left(\mathrm{hr} \cdot \mathrm{ft} \cdot{ }^{\circ} \mathrm{F}\right)\right)$ \\
\hline Calculated Borehole Thermal Resistance & $0.19 \mathrm{~K} \cdot \mathrm{m} / \mathrm{W}\left(0.32 \mathrm{hr} \cdot \mathrm{ft} \cdot{ }^{\circ} \mathrm{F} / \mathrm{Btu}\right)$ \\
\hline Calculated Thermal Diffusivity & $660 \mathrm{~cm}{ }^{2} / \mathrm{day}\left(0.71 \mathrm{ft}{ }^{2} / \mathrm{day}\right)$ \\
\hline
\end{tabular}




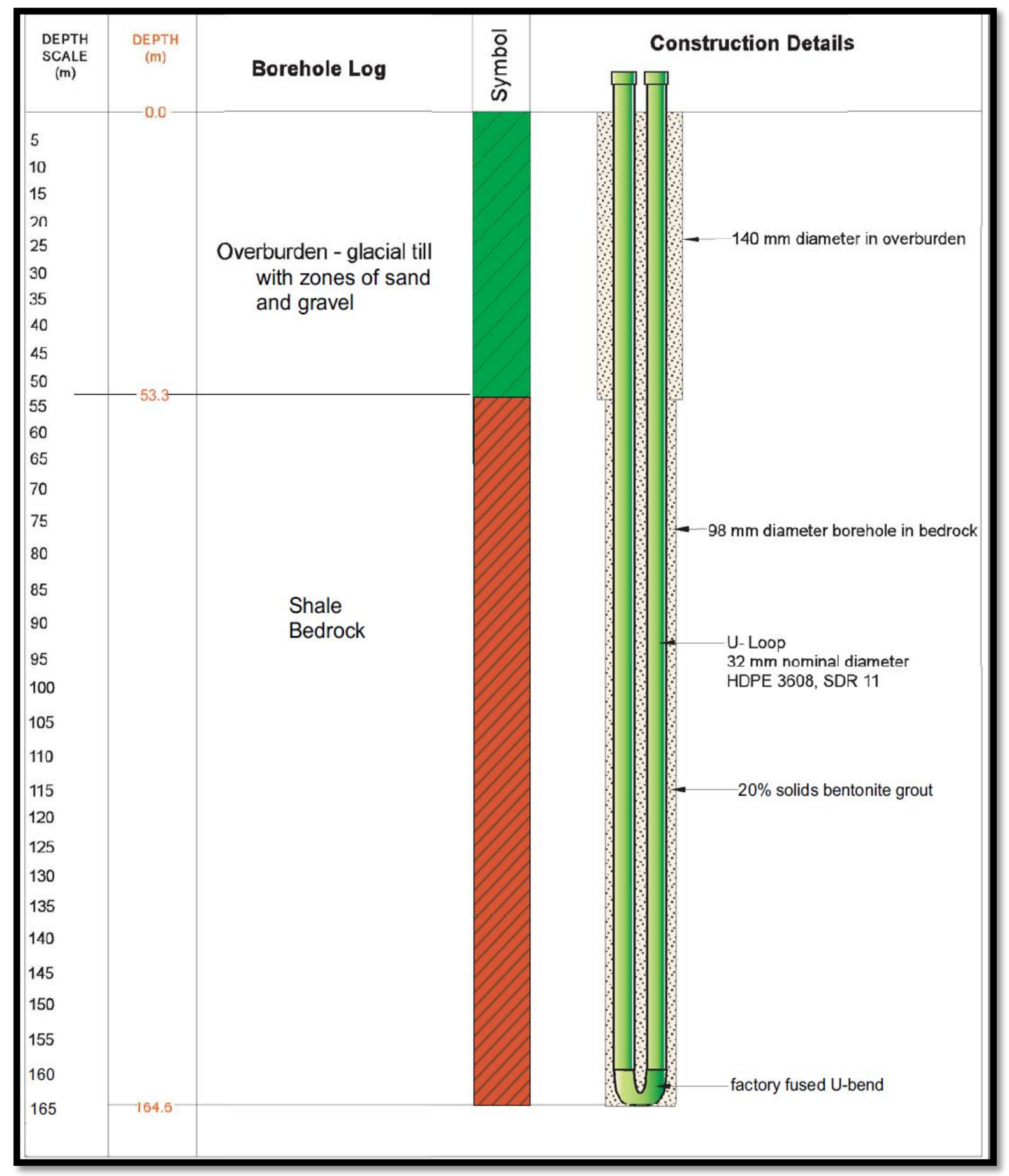

Figure 3.7 : Test borehole log and construction details (GeoEnergy, 2011) 


\section{CHAPTER 4}

\section{Methodology}

The Archetype Sustainable House was designed and constructed as a laboratory for green building technology testing and research with over 300 calibrated sensors installed to monitor the performance of the electrical/mechanical systems and energy fluxes into and out of the house. A National Instruments (NI) data acquisition (DAQ) system is used to process data received from the various sensors. The DAQ system is designed to be very flexible so that the wiring of sensors can be significantly reduced and the associated signal interference can be minimized. The DAQ system consists of a backplane, a controller, modules, connector blocks, power suppliers, LabVIEW software platform and the computer. The selection of modules depends on the output signal of sensors. This output signal is converted into corresponding engineering units by the LabVIEW software. The LabVIEW software has been programmed to provide real-time monitoring and data processing. Measurements are collected at 5-second intervals and recorded in an MS SQL database (Zhang, Barua, and Fung, 2011).

\subsection{Monitoring Systems: Ground Source Heat Pump}

To analyze the thermal performance of the GSHP system using the monitoring systems, data for various operating conditions were obtained. A schematic of the GSHP in House B is shown in Figure 4.1, depicting the ground loops lines, the buffer tank line, and the desuperheater line with the corresponding sensors and their locations. Also, seven temperature sensors have been installed in each vertical loop to monitor the temperature variation with depth during the test. The sensors are installed in the HSRTD sensor pipes which are filled with water as shown in Figure 4.2. The reason for filling the HSRTD sensor pipes with water is to decrease the response time. Tables 4.1-4.5 list the sensors utilized in gathering the required data for the GSHP system and the ground loop system. 


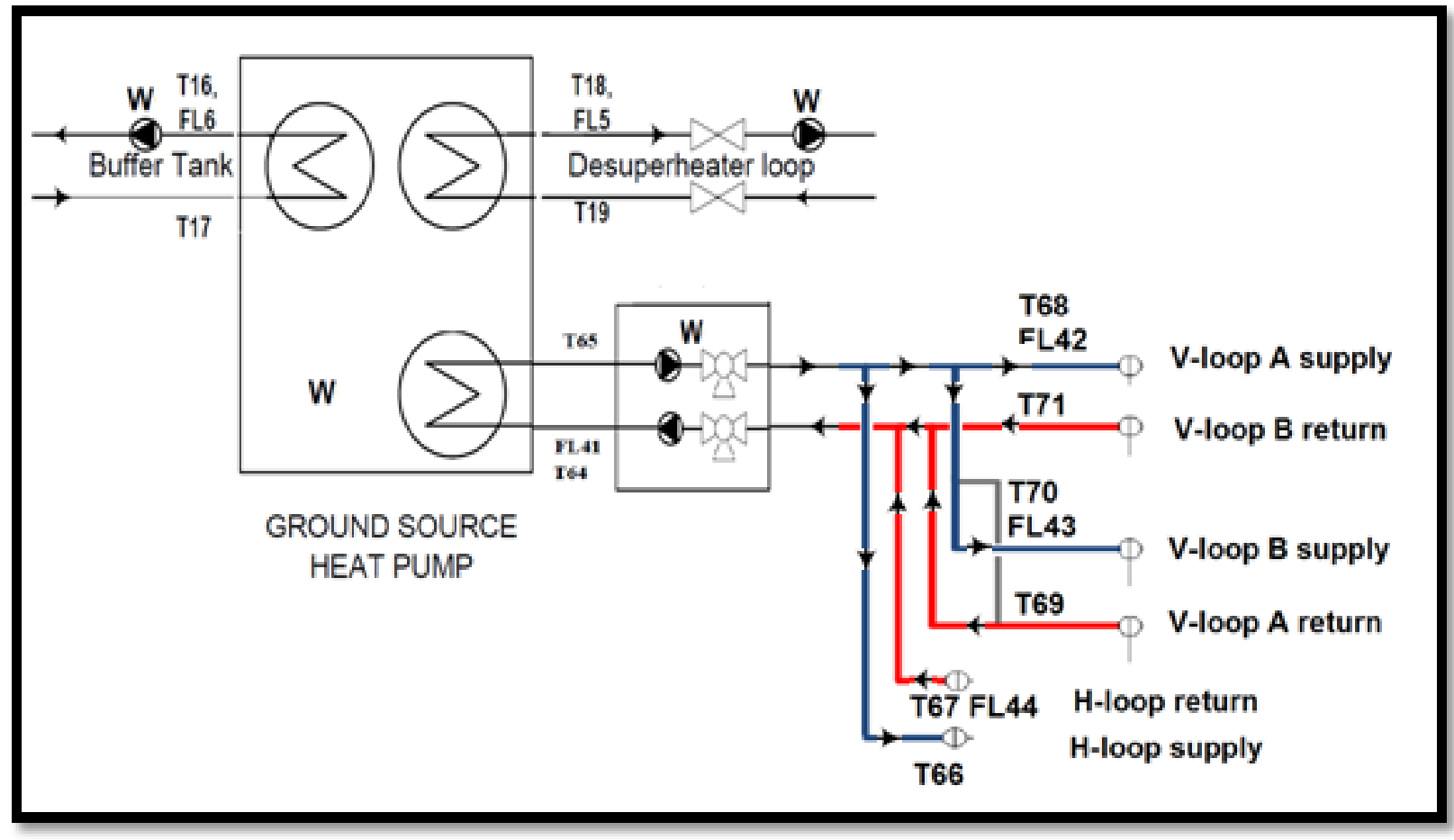

Figure 4.1 : Schematic of the GSHP in House B and the ground loop flow control system

Table 4.1 : Outdoor temperature and relative humidity sensors

\begin{tabular}{|c|c|c|c|c|c|}
\hline MAX Address & Signal & Sensor & Sensor model & Type & Location \\
\hline B-CFP2-M3-CH14 & $\mathrm{mA}$ & RH24 & Dwyer RHT-D & RH & FA (north side wall) \\
\hline B-CFP2-M3-CH15 & $\mathrm{mA}$ & AT24 & Dwyer RHT-D & AT & FA (north side wall) \\
\hline
\end{tabular}

Table 4.2 : Flow rate sensors

\begin{tabular}{|c|c|c|c|c|}
\hline MAX Address & Signal & Sensor & Sensor model & Location \\
\hline B-CFP2-M7-CH0 & V & FL41 & Proteus 08016BN40QC & GSHP supply \\
\hline B-CFP2-M7-CH1 & V & FL42 & Proteus 08012BN16QC & Vertical loop-A supply \\
\hline B-CFP2-M7-CH2 & V & FL43 & Proteus 08012BN16QC & Vertical loop-B supply \\
\hline B-CFP2-M7-CH3 & V & FL44 & Proteus 08012BN16QC & Horizontal loop supply \\
\hline B-CFP2-M7-CH6 & V & FL6 & Proteus 0812BN19 & GSHP to buffer tank \\
\hline B-CFP1-M3-CH6 & Pulse & FL5 & GEMS 173935 & GSHP to Desuperheater \\
\hline
\end{tabular}


Table 4.3 : Temperature sensors connected to the GSHP

\begin{tabular}{|c|c|c|c|c|}
\hline MAX Address. & Signal & Sensor & Sensor model & Location \\
\hline B-CFP8-M3-CH0 & Ohms & T64 & Pt. 500 & Supply to GSHP \\
\hline B-CFP8-M3-CH1 & Ohms & T65 & Pt. 500 & Return from GSHP \\
\hline B-CFP8-M3-CH4 & Ohms & T68 & Pt. 500 & To vertical loop-A \\
\hline B-CFP8-M3-CH5 & Ohms & T69 & Pt. 500 & From vertical loop-A \\
\hline B-CFP8-M3-CH6 & Ohms & $\mathrm{T} 70$ & Pt. 500 & To vertical loop-B \\
\hline B-CFP8-M3-CH7 & Ohms & $\mathrm{T} 71$ & Pt. 500 & From vertical loop-B \\
\hline B-CFP8-M3-CH2 & Ohms & T66 & Pt. 500 & To horizontal loops \\
\hline B-CFP8-M3-CH3 & Ohms & T67 & Pt. 500 & From horizontal loops \\
\hline B-CFP2-M6-CH2 & Ohms & $\mathrm{T} 17$ & Pt. 500 & Buffer tank to GSHP \\
\hline B-CFP2-M6-CH3 & Ohms & T16 & Pt. 500 & GSHP to buffer tank \\
\hline B-CFP1-M2-CH4 & Ohms & T18 & Pt. 500 & Pre Heat Tank to Desuperheater \\
\hline B-CFP1-M2-CH5 & Ohms & T19 & Pt. 500 & Desuperheater to Pre Heat Tank \\
\hline
\end{tabular}

Table 4.4 : Power sensors connected to the GSHP

\begin{tabular}{|c|l|l|l|l|}
\hline MAX Address. & Signal & Sensor & Sensor model & Location \\
\hline B-CFP7-M1-CH6 & Pulse & 3-P-1 & Wattnode & GSHP compressor: 50 Amps \\
\hline B-CFP7-M2-CH2 & Pulse & 5-P3-3 & Wattnode & GSHP circ. pump: 5 Amps \\
\hline B-CFP7-M2-CH0 & Pulse & 5-P3-1 & Wattnode & GSHP to buffer tank: 5 Amps \\
\hline B-CFP7-M2-CH1 & Pulse & 5-P3-2 & Wattnode & Desuperheater pump: 5 Amps \\
\hline
\end{tabular}


The first task was to examine the collected data and ensure the values were within an acceptable range. One way of validating the GSHP data was to compare it with the manufacturer's performance data. The data obtained from the manufacturer for the heat pump performance were divided into cooling performance and heating performance. The data related to this study were collected before each test period using a program called LabVIEW, and then stored using Microsoft SQL Server. During the test period, there were points where the data were out of the normal range and in some rare cases some data points were not recorded. Out of range data points were eliminated from the regular data points to obtain steady accurate results.

Table 4.5 : Temperature sensors in the test pipes

\begin{tabular}{|c|c|c|c|}
\hline MAX Address & Signal & Depth & Location \\
\hline B-CFP8-M1-CH0 & Ohms & $250 \mathrm{ft}$ & \multirow{7}{*}{$\begin{array}{l}\text { Vertical test } \\
\text { borehole A }\end{array}$} \\
\hline B-CFP8-M1-CH1 & Ohms & $200 \mathrm{ft}$ & \\
\hline B-CFP8-M1-CH2 & Ohms & $120 \mathrm{ft}$ & \\
\hline B-CFP8-M1-CH3 & Ohms & $60 \mathrm{ft}$ & \\
\hline B-CFP8-M1-CH4 & Ohms & $30 \mathrm{ft}$ & \\
\hline B-CFP8-M1-CH5 & Ohms & $15 \mathrm{ft}$ & \\
\hline B-CFP8-M1-CH6 & Ohms & $5 \mathrm{ft}$ & \\
\hline B-CFP8-M2-CH0 & Ohms & $250 \mathrm{ft}$ & \multirow{7}{*}{$\begin{array}{l}\text { Vertical test } \\
\text { borehole B }\end{array}$} \\
\hline B-CFP8-M2-CH1 & Ohms & $200 \mathrm{ft}$ & \\
\hline B-CFP8-M2-CH2 & Ohms & $120 \mathrm{ft}$ & \\
\hline B-CFP8-M2-CH3 & Ohms & $60 \mathrm{ft}$ & \\
\hline B-CFP8-M2-CH4 & Ohms & $30 \mathrm{ft}$ & \\
\hline B-CFP8-M2-CH5 & Ohms & $15 \mathrm{ft}$ & \\
\hline B-CFP8-M2-CH6 & Ohms & $5 \mathrm{ft}$ & \\
\hline
\end{tabular}




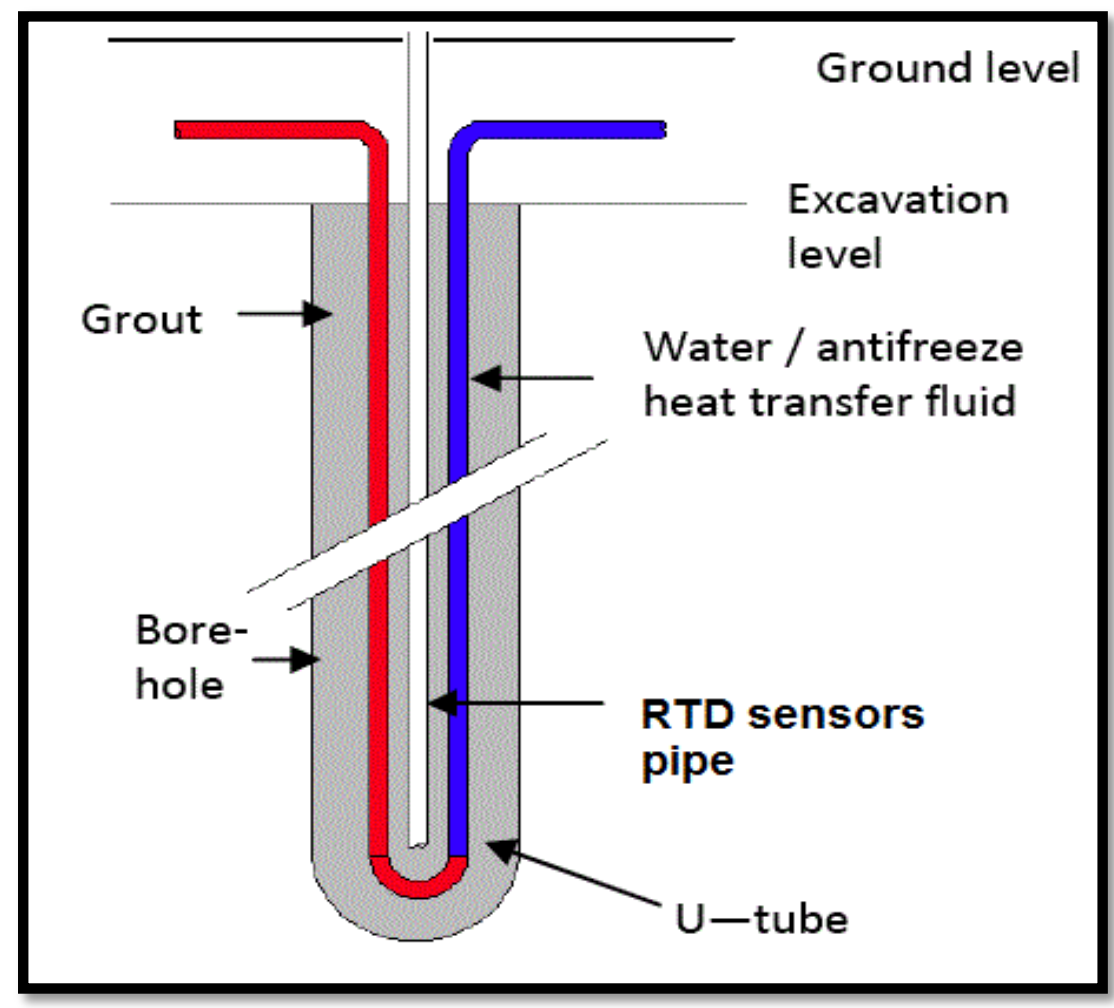

Figure 4.2 : Schematic of the HSRTD test pipe

\subsection{Ground Source Heat Pump Equations}

A schematic of the House B GSHP is given in Figure 4.3. The ground source heat pump performance can be determined using the following equations (ASHRAE, 2009):

$\dot{Q}_{H e a t}=\dot{m}_{w} C p_{w}\left(T_{w, o}-T_{w, i}\right)$

$\dot{Q}_{\text {cool }}=\dot{m}_{w} C p_{w}\left(T_{w, o}-T_{w, i}\right)$

where:

$\dot{\mathrm{Q}}_{\text {Heat/Cool }}$ : Thermal power output $(\mathrm{kW})$

$\dot{\mathrm{m}}_{\mathrm{w}} \quad$ : Mass flow rate of water $(\mathrm{kg} / \mathrm{s})$

$\mathrm{Cp}_{\mathrm{w}} \quad$ : Specific heat of water $(\mathrm{kJ} / \mathrm{kg} \cdot \mathrm{K})$

$\mathrm{T}_{\mathrm{w}, \mathrm{o}} \quad$ : Water temperature leaving the GSHP to the buffer $\operatorname{tank}\left({ }^{\circ} \mathrm{C}\right)$

$\mathrm{T}_{\mathrm{w}, \mathrm{i}} \quad$ : Water temperature entering the GSHP from the buffer tank $\left({ }^{\circ} \mathrm{C}\right)$ 


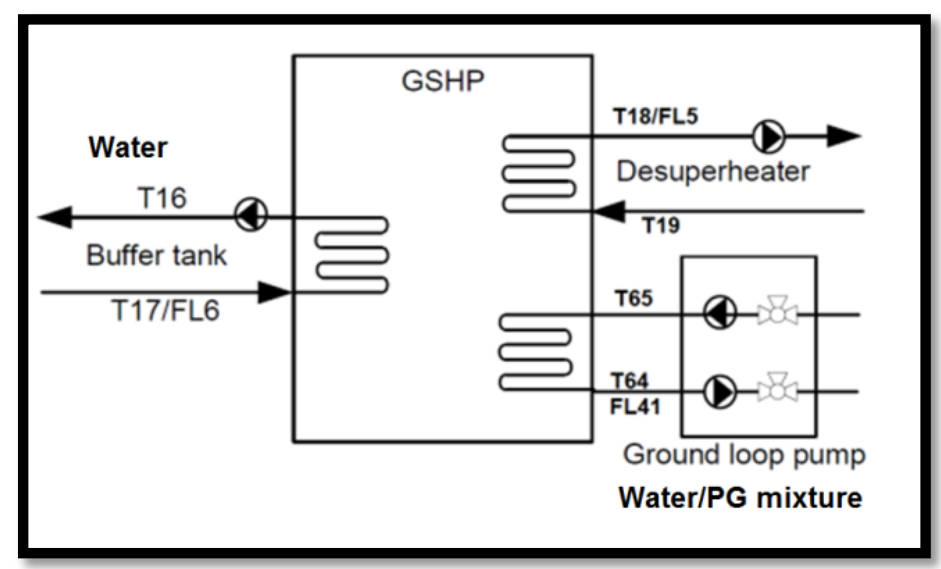

Figure 4.3 : Schematic of the GSHP

The flow rate sensors provide output in litres per minute LPM, thus Equations 1 and 2 were expressed in terms of volumetric flow rate $\dot{\boldsymbol{V}}(\mathrm{LPM})$, and density $\boldsymbol{\rho}\left(\mathrm{kg} / \mathrm{m}^{3}\right)$. The mass flow rate of water $\dot{m}$ in $(\mathrm{kg} / \mathrm{s})$ can be expressed as:

$\dot{m}=\dot{V}\left(\frac{L}{\min }\right) \times \rho\left(\frac{k g}{m^{3}}\right) \times(1 \mathrm{~min} / 60 \mathrm{~s}) \times\left(1 \mathrm{~m}^{3} / 1000 \mathrm{~L}\right)$

$\dot{m}=1.667 \times 10^{-5} \dot{V} \rho$

The maximum and the minimum recorded water temperatures in the GSHP/buffer-tank loop are $61^{\circ} \mathrm{C}$ and $0^{\circ} \mathrm{C}$, respectively. The density and the specific heat of water used in the above equations do not significantly change with temperature at that range (see Table A.1 in Appendix A). The specific heat of water was used as a constant $4.187 \mathrm{~kJ} / \mathrm{kg} . \mathrm{K}$ because of the small change in its value with temperature over this range (less than $0.6 \%$ change). However, an Equation was created from the density versus temperature plot for the temperature range of $0.01^{\circ} \mathrm{C}$ to $75^{\circ} \mathrm{C}$ (see Table A.1 in Appendix A).

$\rho_{\text {Water }}=-0.0041 T^{2}-0.0349 T+1000.3$

Where:

$\rho_{\text {Water }}:$ Density of water $\left(\mathrm{kg} / \mathrm{m}^{3}\right)$

$\mathrm{T} \quad$ : Average water temperature of the inlet and the outlet $\left({ }^{\circ} \mathrm{C}\right)$ 
Substituting Equation 4 into Equations 1 and 2, along with a constant specific heat, the flow rate to the buffer tank in LPM (FL6), the supply temperature to the buffer tank (T16), and the return temperature from the buffer tank to the GSHP (T17), the following equations for output heating and cooling in $\mathrm{kW}$ from the GSHP to the buffer tank is obtained as:

$$
\begin{aligned}
& \dot{Q}_{\text {Heat }}=1.667 \times 10^{-5} \times F L 6 \times \rho \times 4.187 \times(T 16-T 17) \\
& \dot{Q}_{C o o l}=1.667 \times 10^{-5} \times F L 6 \times \rho \times 4.187 \times(T 17-T 16)
\end{aligned}
$$

Once the output heating and cooling is obtained, equations 8 and 9 can be used to investigate the coefficient of performance of the system using the thermal heat output and the electricity consumption of the unit which includes the compressor, the ground loop circulation pumps, and the buffer-tank pump.

$$
\begin{gathered}
C O P_{\text {Heat }}=\frac{\dot{Q}_{\text {Heat }}}{\dot{Q}_{\text {electrical }}} \\
C O P_{\text {Cool }}=\frac{\dot{Q}_{\text {Cool }}}{\dot{Q}_{\text {electrical }}}
\end{gathered}
$$

where:

$$
\dot{Q}_{\text {electrical }}(k W)=W_{\text {compressor }}+W_{\text {Ground loop pump }}+W_{\text {Buffer tank pump }}
$$

\subsection{Heat Extraction/Rejection from/to Ground Loops}

Similar to the heating/cooling output to the buffer tank, the heat extraction and rejection from and to the ground via the ground loops are calculated in units of $\mathrm{kW}$. The ground loops use a mixture of water and antifreeze called Propylene Glycol (PG). The volume ratio is 20\% Propylene Glycol and $80 \%$ water by volume. A graph was created (as shown in Figure A.2 in Appendix A) to illustrate the relationship between the density of the mixture at various 
temperatures. Also, the relation between the density, specific heat and fluid temperature are shown in Table A.2 in Appendix A. These relationships are used to calculate the heat extraction/rejection from/to the ground loops. The density and the specific heat of the mixture do not significantly change within the test temperature range. The specific heat of the mixture was used as a constant $3.97(\mathrm{~kJ} / \mathrm{kg} . \mathrm{K})$ because of the small change in its value with temperature (less than $1.5 \%$ change). However, an equation was created from the density versus temperature plot for the temperature range of $-10^{\circ} \mathrm{C}$ to $100^{\circ} \mathrm{C}$ (see Figure A.2 in Appendix A).

$\rho_{P G}=-0.0025 T^{2}-0.29 T+1027$

where:

$\rho_{\mathrm{PG}}:$ Density of PG mixture $\left(\mathrm{kg} / \mathrm{m}^{3}\right)$

$\mathrm{T}$ : Average mixture temperature of the inlet and the outlet $\left({ }^{\circ} \mathrm{C}\right)$

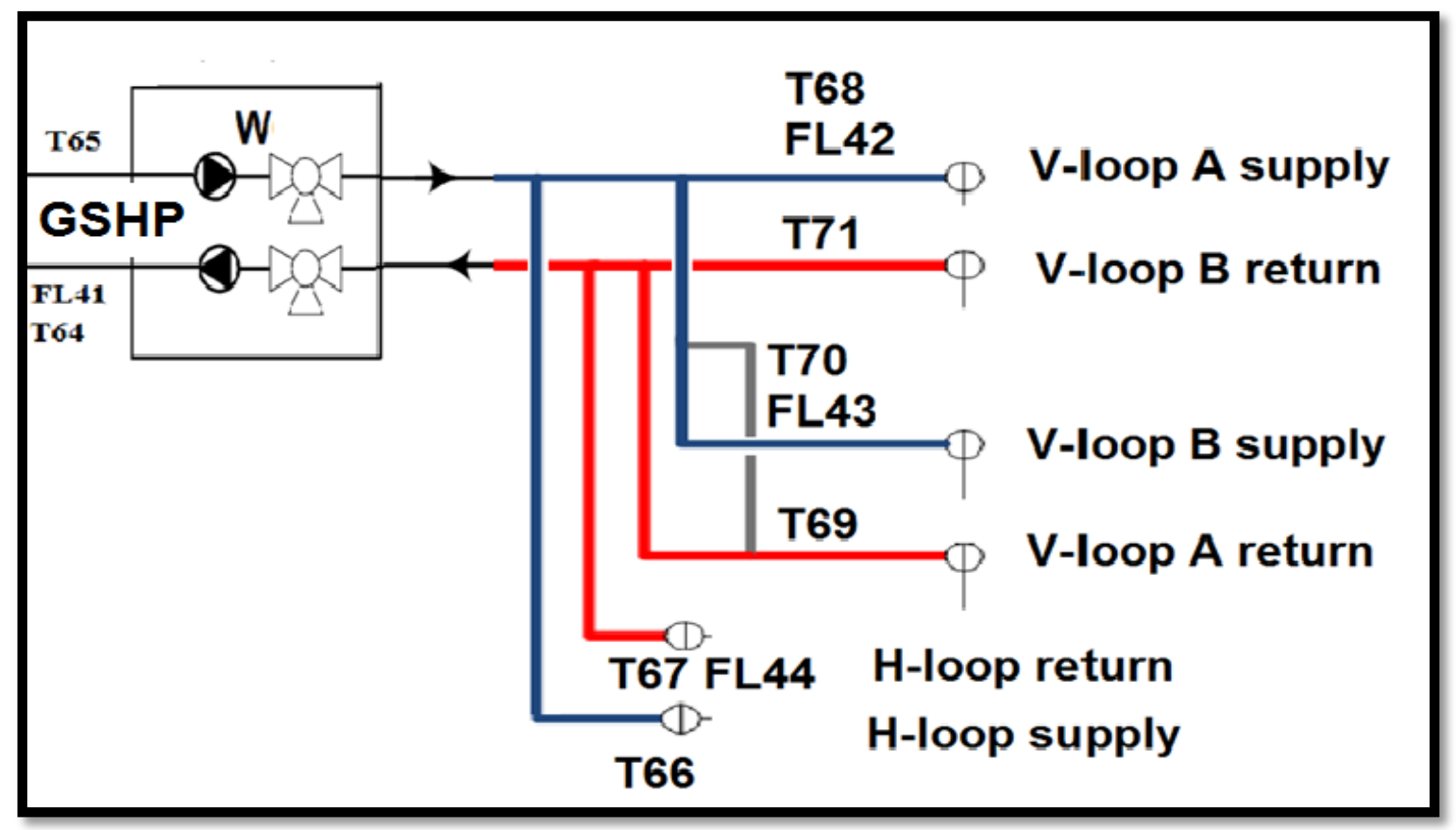

Figure 4.4 : Schematic of the GSHP loops

Substituting the constant specific heat, the flow rate to each loop in LPM (FL44, FL42, FL43), the supply temperature to each loop (T66, T68, T70), and the return temperatures (T67, 
T69, T71), the following equations are used for heat extraction/rejection from/to ground loops in $\mathrm{kW}$ as follows:

Horizontal loop Heat extraction/rejection :

$\dot{Q}_{H-\text { loop }}=1.667 \times 10^{-5} \times F L 44 \times \rho \times 3.97 \times(T 66-T 67)$

Vertical loop-A Heat extraction/rejection :

$\dot{Q}_{V-\text { loop A }}=1.667 \times 10^{-5} \times F L 42 \times \rho \times 3.97 \times(T 68-T 69)$

Vertical loop-B Heat extraction/rejection :

$\dot{Q}_{V-\operatorname{loop~B}}=1.667 \times 10^{-5} \times F L 43 \times \rho \times 3.97 \times(T 70-T 71)$

\subsection{Heat supplied from the desuperheater}

Similar to the heating/cooling output from the buffer tank, water is used in the desuperheater loop. The desuperheater supplied heat to the preheat tank can be obtained as follows:

$\dot{Q}_{\text {desuperheater }}=1.667 \times 10^{-5} \times F L 5 \times \rho \times 4.187(T 18-T 19)$

where:

FL15 : The water flow rate in the desuperheater loop (L/min)

T19 : The temperature of water entering the preheat tank $\left({ }^{\circ} \mathrm{C}\right)$

T18 : The temperature of water entering the GSHP $\left({ }^{\circ} \mathrm{C}\right)$

$\rho \quad:$ The density of desuperheater water $\left(\mathrm{kg} / \mathrm{m}^{3}\right)$ 


\section{CHAPTER 5}

\section{Data Analysis}

In the four tests of this study, the first two tests were to evaluate the heating and cooling performance of the GSHP system using the vertical ground loop (two U-loops in parallel). In the other two tests, the combination of the vertical loop (two U-loops in parallel) and the horizontal loop (two J-loops in parallel) were used. Table 5.1 summarizes the four tests in this study.

Table 5.1 : Summary of the tests

\begin{tabular}{|c|c|c|c|}
\hline \multicolumn{2}{|c|}{$\begin{array}{l}\text { The vertical loop tests } \\
\text { (The two U-loops in parallel) }\end{array}$} & \multicolumn{2}{|c|}{$\begin{array}{l}\text { The vertical and horizontal loops tests } \\
\text { (The two U-loops and the two J-loops in parallel) }\end{array}$} \\
\hline $\begin{array}{c}\text { Heating } \\
\text { (May } 14-\text { June 4, 2013) }\end{array}$ & $\begin{array}{c}\text { Cooling } \\
\text { (June } 21-\text { July 8, 2013) }\end{array}$ & $\begin{array}{c}\text { Cooling } \\
\text { (July } 19-\text { Aug. 7, 2013) }\end{array}$ & $\begin{array}{c}\text { Cooling } \\
\text { (Aug. } 9-\text { Sep. 4, 2013) }\end{array}$ \\
\hline $\begin{array}{l}\text { Vertical loops: } \\
\text { Reynolds number: } \\
\mathbf{8 3 0 0} \\
\text { Total flow rate: } \mathbf{4 8} \text { LPM }\end{array}$ & $\begin{array}{l}\text { Vertical loops: } \\
\text { Reynolds number: } \\
\mathbf{8 3 0 0} \\
\text { Total flow rate: } \mathbf{4 8} \text { LPM }\end{array}$ & $\begin{array}{l}\text { Vertical loops: } \\
\text { Reynolds number: } \\
\mathbf{5 5 4 0} \\
\text { Total flow rate: } \mathbf{3 2} \text { LPM }\end{array}$ & $\begin{array}{l}\text { Vertical loops: } \\
\text { Reynolds number: } \\
\mathbf{4 8 4 0} \\
\text { Total flow rate: } \mathbf{2 8} \text { LPM }\end{array}$ \\
\hline $\begin{array}{l}\text { Horizontal loops: } \\
\text { Not used }\end{array}$ & $\begin{array}{l}\text { Horizontal loops: } \\
\text { Not used }\end{array}$ & $\begin{array}{l}\text { Horizontal loops: } \\
\text { Reynolds number: } \\
\mathbf{4 4 0 0} \\
\text { Total flow rate: } \mathbf{3 2} \text { LPM }\end{array}$ & $\begin{array}{l}\text { Horizontal loops: } \\
\text { Reynolds number: } \\
\mathbf{4 8 4 0} \\
\text { flow rate: } \mathbf{3 5} \text { LPM }\end{array}$ \\
\hline \multicolumn{2}{|c|}{ GSHP/buffer-tank loop flow rate: 50.4 LPM } & \multicolumn{2}{|c|}{ GSHP/buffer-tank loop flow rate: 47.3 LPM } \\
\hline
\end{tabular}




\section{-The Two Vertical Loops}

\subsubsection{Heating mode using the vertical loops (May 14 - June 4, 2013)}

The winter data collection was originally planned to start in January 2013 using both the horizontal and the vertical loops till the end of heating season. However, due to the experimental setup, there have been some delays in starting the tests. Some major delays have been due to the following reasons:

- The failure of some experimental equipment and sensor vendors to make delivery on schedule.

- The delay of repairing one of the key equipment in the experiment, the GSHP, due to lack of parts.

- An unexpected ground loop leak at the experiment site, which took weeks to locate and repair.

For those reasons, the winter data collection was started on May $14^{\text {th }}$ for a period of three weeks till June $4^{\text {th }}$. During this period, the ambient temperature range was between $2^{\circ} \mathrm{C}$ and $30^{\circ} \mathrm{C}$ and provided a good range to analyze the performance of the GSHP and heat extraction from the vertical ground loops.

In this part of the test, the vertical loops were used to extract heat from the ground to heat House B. For the three weeks of the heating mode test, the GSHP compressor, the ground loop circulating pump, and the GSHP to buffer-tank pump start at the same time when the temperature of the load (the water in the buffer tank) drops below $33^{\circ} \mathrm{C}$ and stop when the temperature reaches $43^{\circ} \mathrm{C}$. Those temperatures are based on the designed temperature of the components connected to the buffer tank. The flow rate of the water in the GSHP/buffer-tank loop is almost constant at around 50.4 LPM (13.3 US GPM) at all times. Also, the flow rate of the ground loop is almost constant at around 48 LPM (12.7 US GPM) divided equally in each of the vertical loops. 
The daily heating and power consumption of different components of the GSHP system were investigated for the three-week period. Due to the enormous amount of data, an average daily representation will be used in most of this thesis and a run-time sample of operation of a cycle will be shown when needed. The performance of the GSHP is analyzed considering the compressor, the two circulating pumps, and the buffer-tank pump operating hours and consumptions. It should be noted that the majority of the electrical consumption of the system is due to the GSHP compressor which starts operating at around $2500 \mathrm{~W}$ and increases with time and accounted for $77 \%$ to $81 \%$ of the power consumption. In Figure 5.1, one cycle sample shows the power draw of the compressor, the circulating pumps, and the buffer-tank pump for one cycle. When the GSHP starts, the compressor starts operating at around $2500 \mathrm{~W}$, whereas the circulating pumps and the buffer-tank pump draw around $680 \mathrm{~W}$ and $190 \mathrm{~W}$, respectively. While the circulating pumps and the buffer-tank pump power draw remain almost constant throughout the cycle, the compressor power draw increases with time until it reaches $3850 \mathrm{~W}$ at the end of the cycle. The increase of the compressor consumption is due to the increasing temperature difference between the two sides of the GSHP with time as could be seen in Appendix C.1.

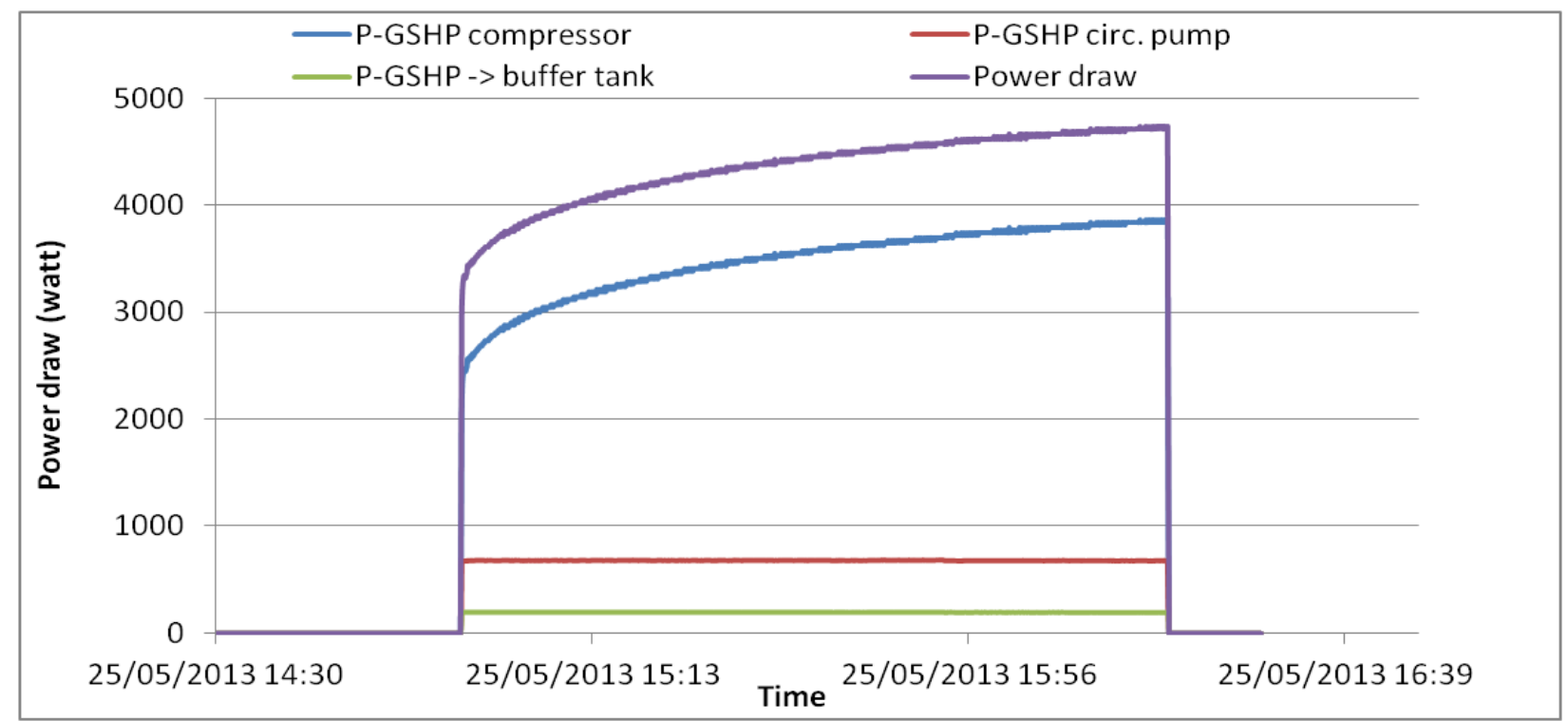

Figure 5.1 : Buffer-tank pump, ground-loop pumps, compressor, and total power draw with time 


\subsubsection{Daily operation}

Figure 5.2 illustrates the GSHP system operation hours and the daily average outdoor temperature starting from May 14 through June 4. The daily average outdoor temperature was calculated for all data points in a day starting from midnight. In the first few days of this test period, the GSHP operation was not stable as seen from the ratio of the daily operating hours \& number of cycles. The total daily consumption is illustrated in Figure 5.3. Figure 5.3 shows the daily heating that the GSHP supplied to the buffer tank. As the daily average outdoor temperature dropped, it is clear that the number of cycles and the operating hours increased to meet the house heating demand. Figure 5.3 illustrates days when heating was not required, and as a result, the GSHP system did not operate. Figure 5.3 also illustrates a peak daily heating and electricity consumption of $140 \mathrm{kWh}$ and $48 \mathrm{kWh}$, respectively. The daily peak heating output and electricity consumption took place on May $28^{\text {th }}$ shortly after the coldest days in the test period. This is due to the thermal mass and the insulation in the house which caused the delay of peak load. Although the daily average outdoor temperature on May $4^{\text {th }}$ was almost the same as on May $28^{\text {th }}$, the daily heating and consumption of the GSHP system are different. Days before the beginning of this heating test period, the GSHP system was put in operation for the first time in the winter season. This created a great load and instability of the GSHP operation in the first few days to increase the house temperature to the desired set point. After days of operation, the GSHP reached more stable operating conditions on May $16^{\text {th }}$. This was noticed from the cycles operating time of the GSHP and the vertical ground loops. During the GSHP stable operation, the cycle average operating time was in the range of $28 \pm 2$ minutes. However, the cycle operating times on May $15^{\text {th }}$ and May $16^{\text {th }}$ were 62 minutes and 42 minutes respectively. The reason for the longer cycle operating times at the beginning of the test period is the high heat extraction from the ground using the vertical ground loops to heat the house. Those high cycle operating times of the GSHP resulted in less time for the ground to recover the amount of heat extracted which lead to colder ground temperatures compared to the more stable conditions where the ground was able to recover and maintain its temperature. The colder ground temperature resulted in longer operating time per cycle to supply the house heating load. 


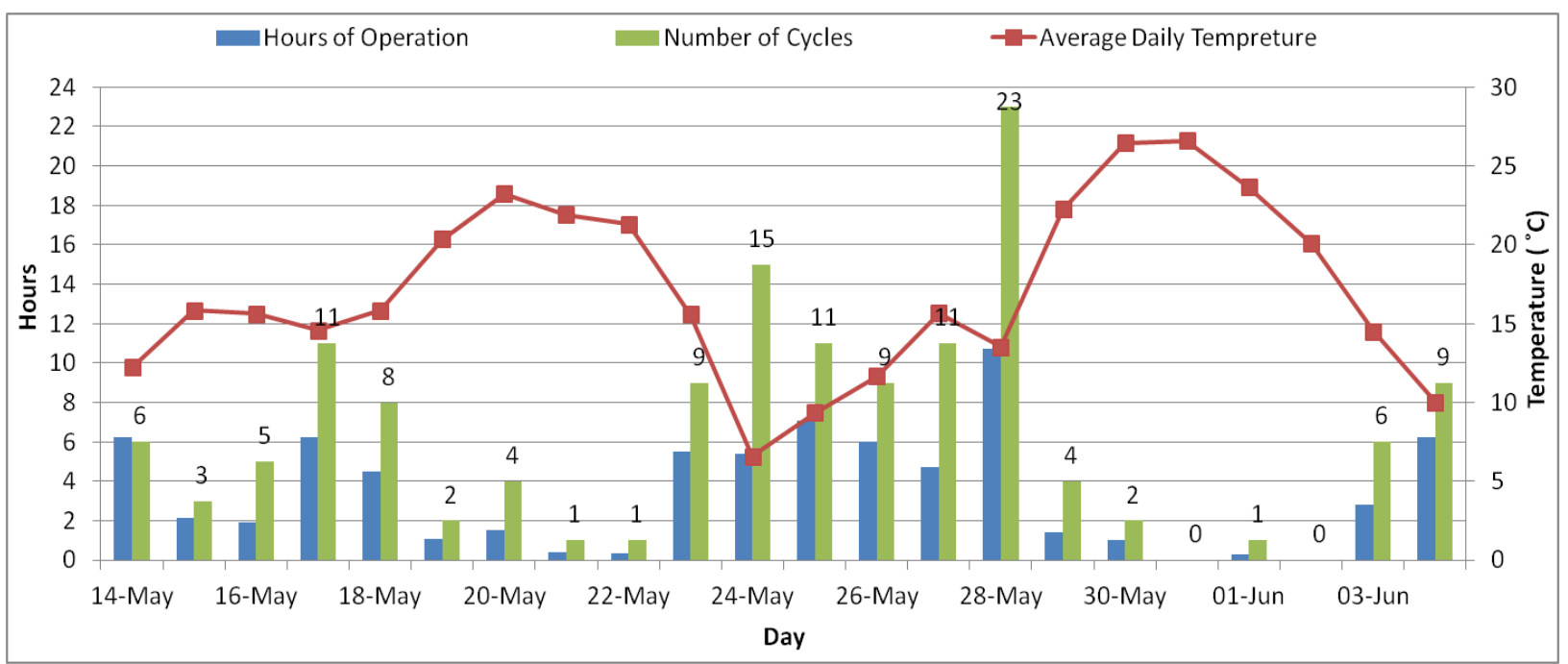

Figure 5.2 : Daily operating hours \& number of cycles of the GSHP system vs. daily average outdoor temperature

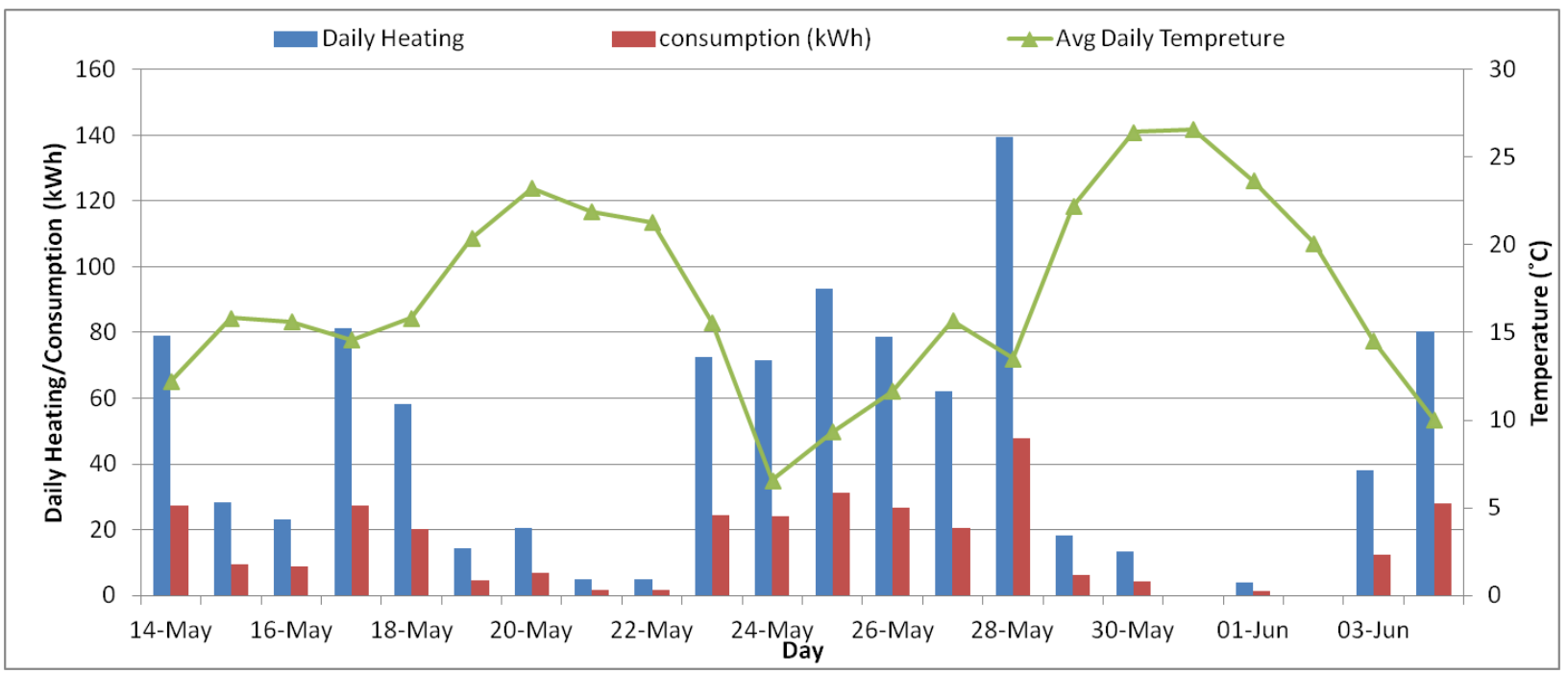

Figure 5.3 : Daily heating and consumption of the GSHP system vs. daily average outdoor temperature

Figure 5.4 shows the daily coefficient of performance (COP) calculated using the daily heating and electricity consumption of the GSHP system in Figure 5.3. The coefficient of performance of the GSHP ranged from 2.6 to 3.1. As evident from the COP, the heat pump is very efficient in the heating mode with an output heating of about 3 times the electricity draw. Also, the lower the outside temperature is, the higher the daily operating hours and number of cycles of the GSHP system. However, it is noticed that there is minimal change in COP with outdoor temperature as evident from the data points in Figure 5.4. Figure 5.5 shows the 
cumulative heating and electricity consumption of the GSHP within this period. The total electricity consumption of the GSHP system during this test period turned out to be $334.5 \mathrm{kWh}$ and the total heating was $986.5 \mathrm{kWh}$ which gives a test period COP of 2.95 which matches with the GSHP specification (2.9-3.0). The reason for these small changes in the COP is because the GSHP system uses the heat of the ground-loop fluid to evaporate the GSHP refrigerant and not the heat of the ambient air as for the air-source heat pump. As a result, the ground-loop return fluid temperature plays a much more significant role in the performance of the GSHP system.

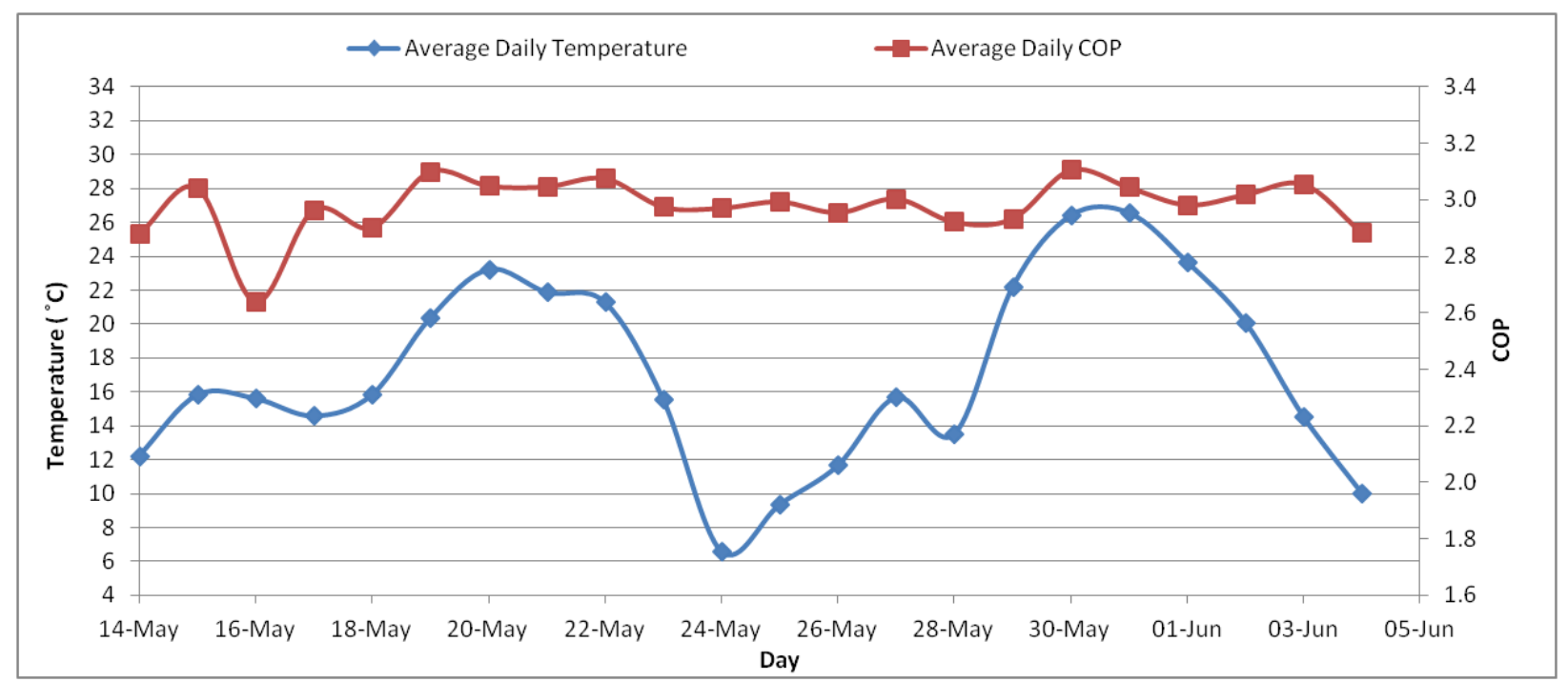

Figure 5.4 : Daily average COP of the GSHP system and daily average outdoor temperature

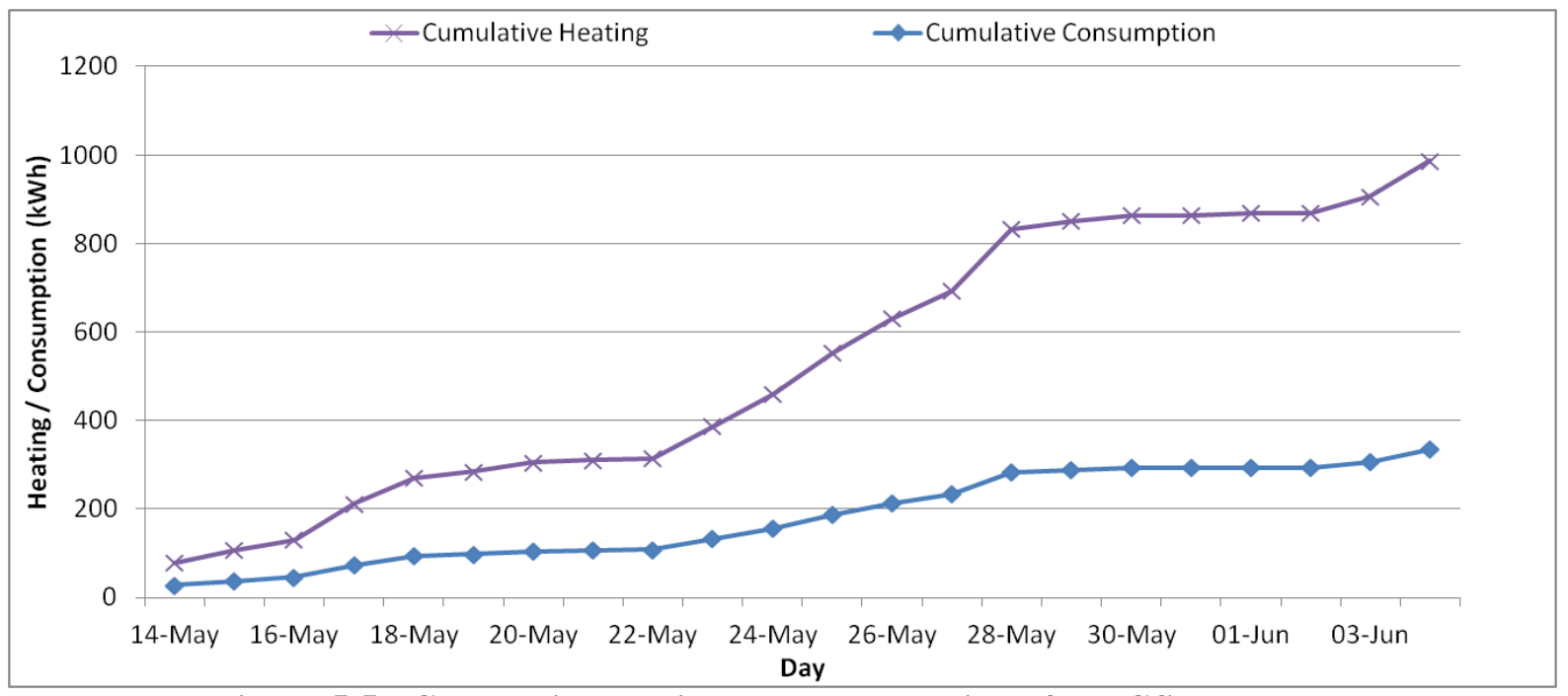

Figure 5.5 : Cumulative heating and consumption of the GSHP system 
The relationship between the daily heating output and the electricity consumption with respect to the average daily outdoor temperature is shown in Figure 5.6. As the outdoor temperature increases, the demand for heating decreases resulting in less operating hours and electricity consumption. Although the daily heating output and the electricity consumption of the GSHP varies with the change of the outdoor temperature, the COP remains almost constant.

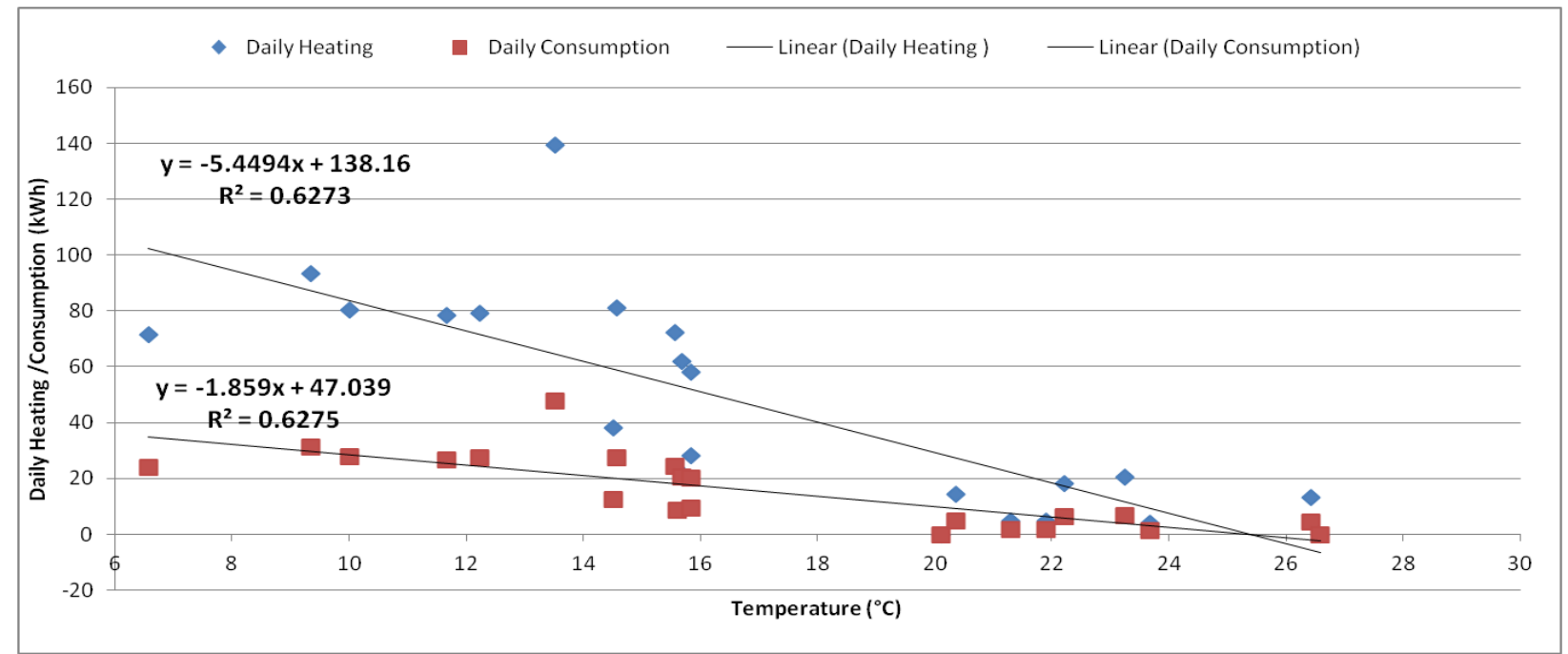

Figure 5.6 : Daily electricity consumption and heating output vs. daily average outdoor temperature

\subsubsection{Entering Source Temperature (EST) and Entering Load Temperature (ELT)}

The fluid return temperature from the ground loop plays a major role on the performance of the GSHP system as seen in Figures 5.7-5.9. In heating mode, the total power draw of the GSHP system increases as the fluid return temperature from the ground decreases. As evident from the data collected, it is mostly because of the compressor power draw as the power draw by the ground-loop and buffer-tank pumps remain almost constant. The lower the fluid return temperature from the ground, the more work is required by the compressor resulting in more power draw as seen in Figure 5.7. On the other hand, the heat output from the GSHP system increases as the return temperature from the ground loop increase as seen in Figure 5.8. As a result, the COP increases by almost $10 \%$ for each one degree Celsius increase in the return fluid temperature. This increase is noticed when the load supply temperature (the water from the buffer tank) range is between $33^{\circ} \mathrm{C}$ and $43^{\circ} \mathrm{C}$ as shown in Figures 5.9 and 5.10. 


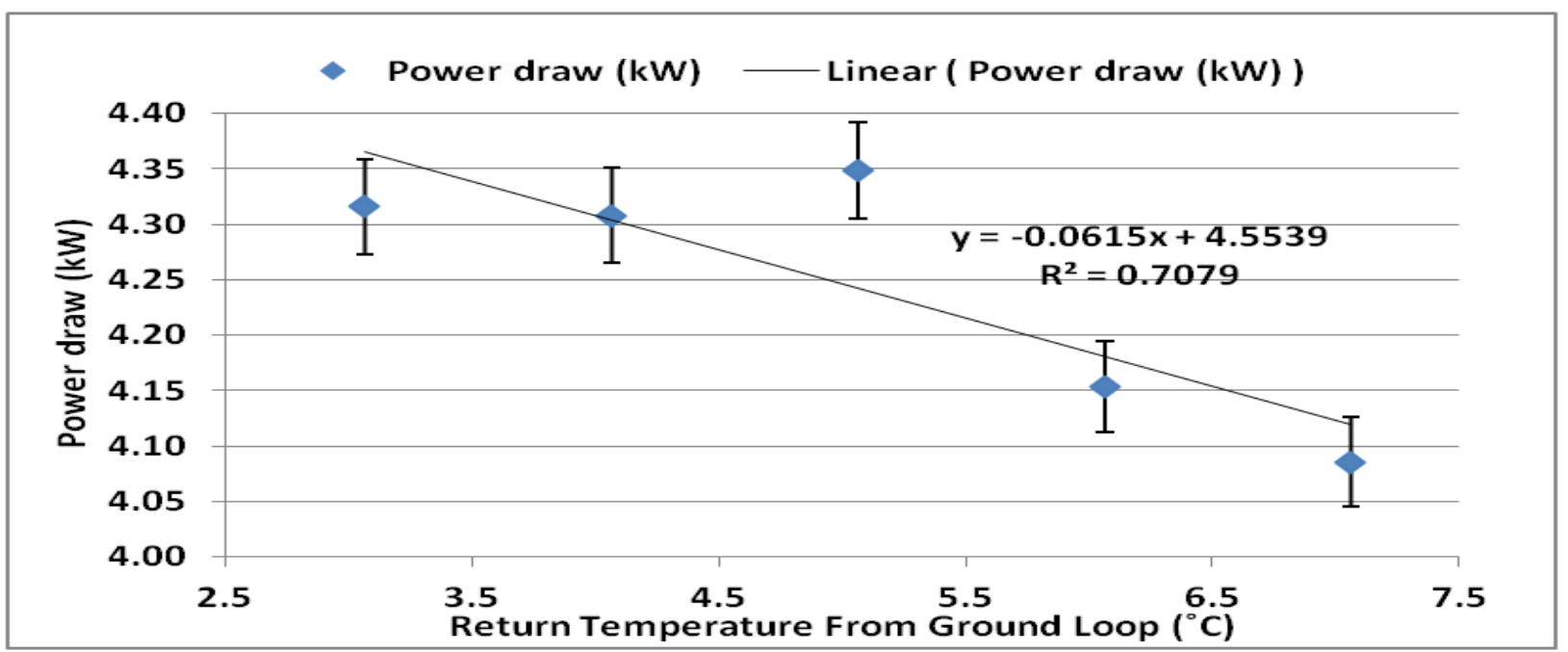

Figure 5.7 : Power draw vs. fluid return temperature from the ground loop

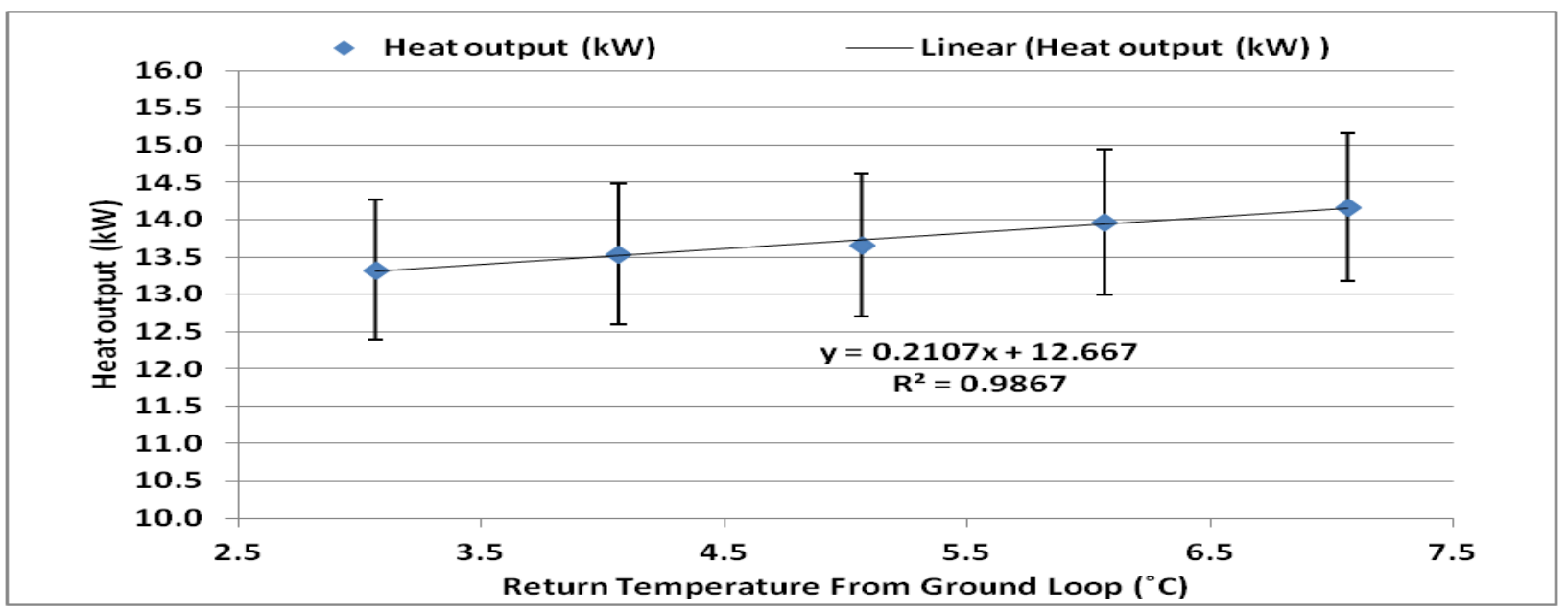

Figure 5.8 : Heat output vs. fluid return temperature from the ground loop

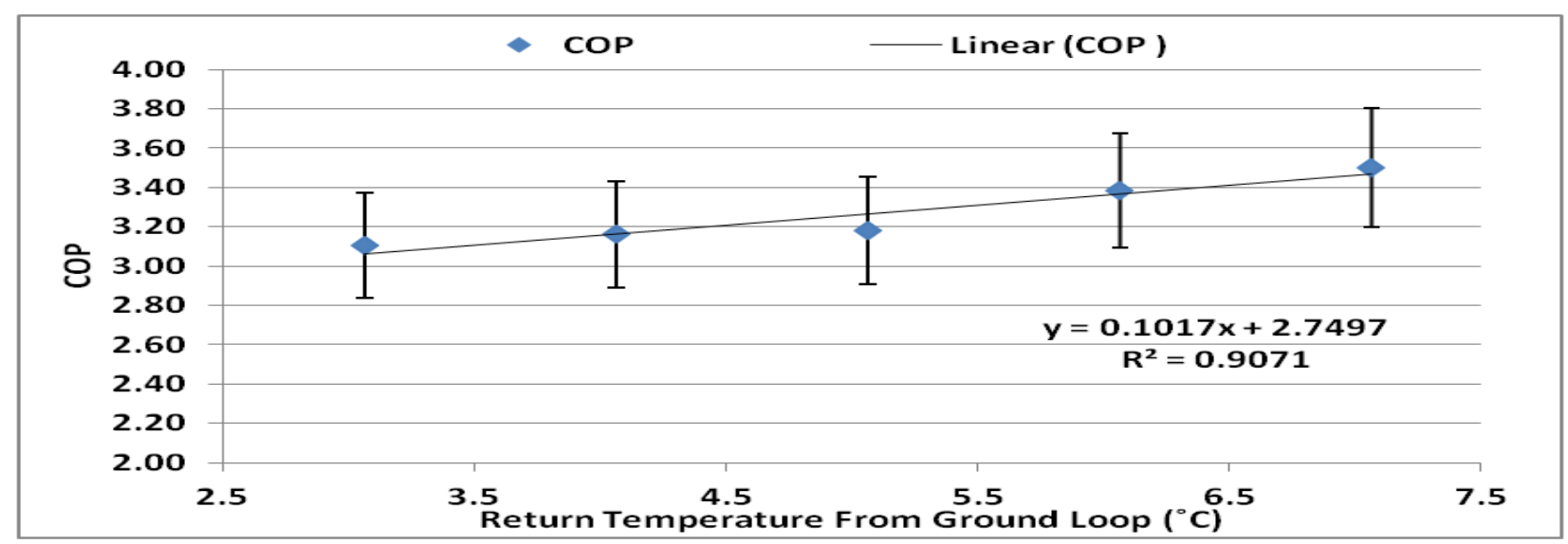

Figure 5.9 : COP vs. fluid return temperature from the ground loop 


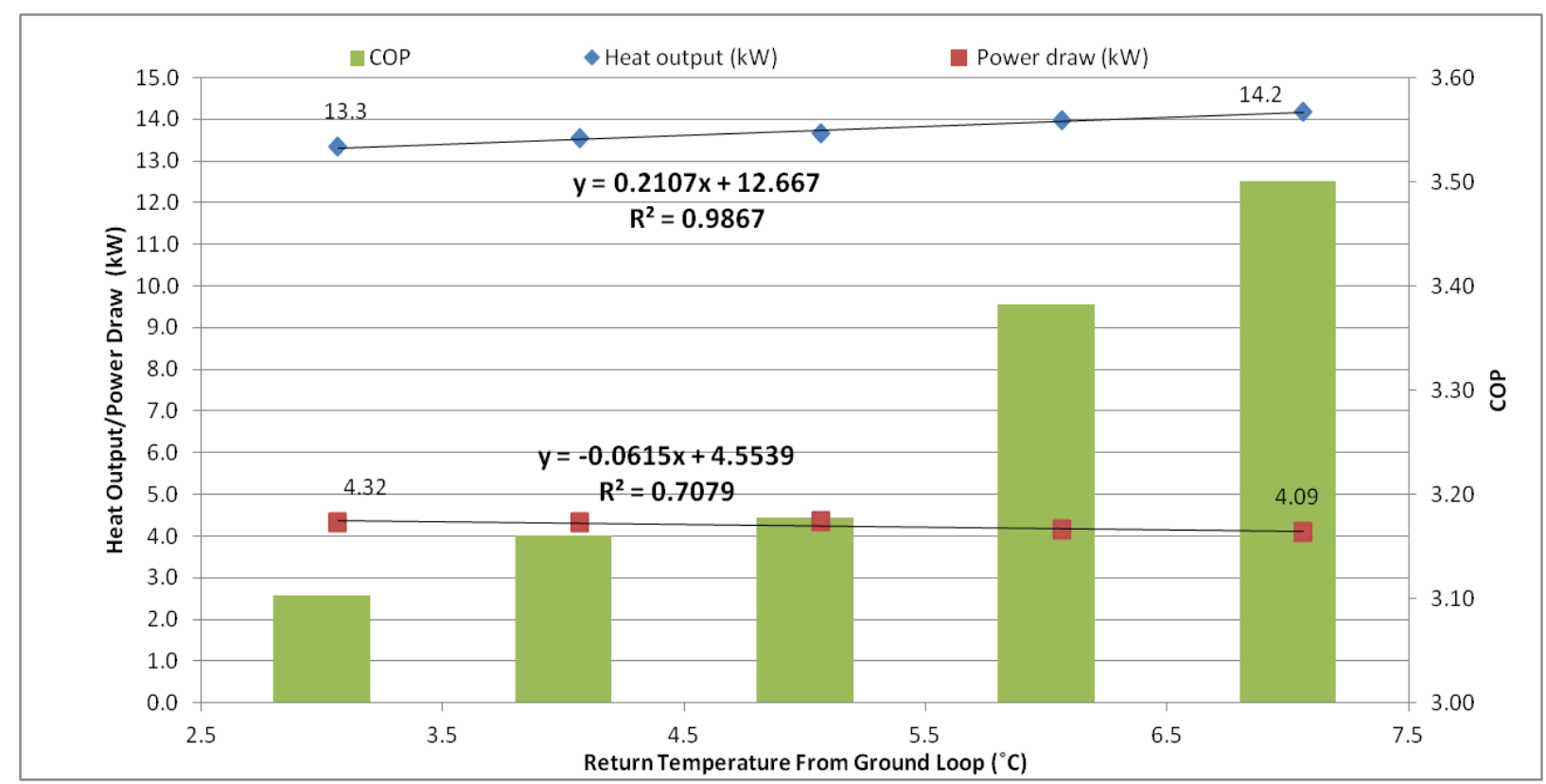

Figure 5.10 : COP, heat output \& power draw vs. fluid return temperature from the ground loop to GSHP

Also, the system COP is affected greatly by the supply load temperature (from the buffer tank to the GSHP). Figure 5.11 shows the system total heating COP changes with the supply load temperature. In theory, the heating COP of the GSHP decreases as the supply load temperature increases. Figure 5.11 shows that the system COP decreases as the temperature increases until around $42^{\circ} \mathrm{C}$. Although the COP continue to decrease after that, the change is smaller. The lower COP at the end of the cycle is due to the higher temperature difference between the GSHP water supply from the buffer tank and GSHP fluid supply from the ground loop. The GSHP starts operating when the buffer tank temperature is around $35^{\circ} \mathrm{C}$. At this point the GSHP COP is at its highest value because the temperature difference between the load and the source temperatures is at its lowest. The low temperature differential for the first transient period of operation decreases the power drawn by the heat pump compressor. With time, the temperature difference between the load and the source increases resulting in lower COP. The details of a regular heating cycle of the GSHP is shown in Appendix C.1. 


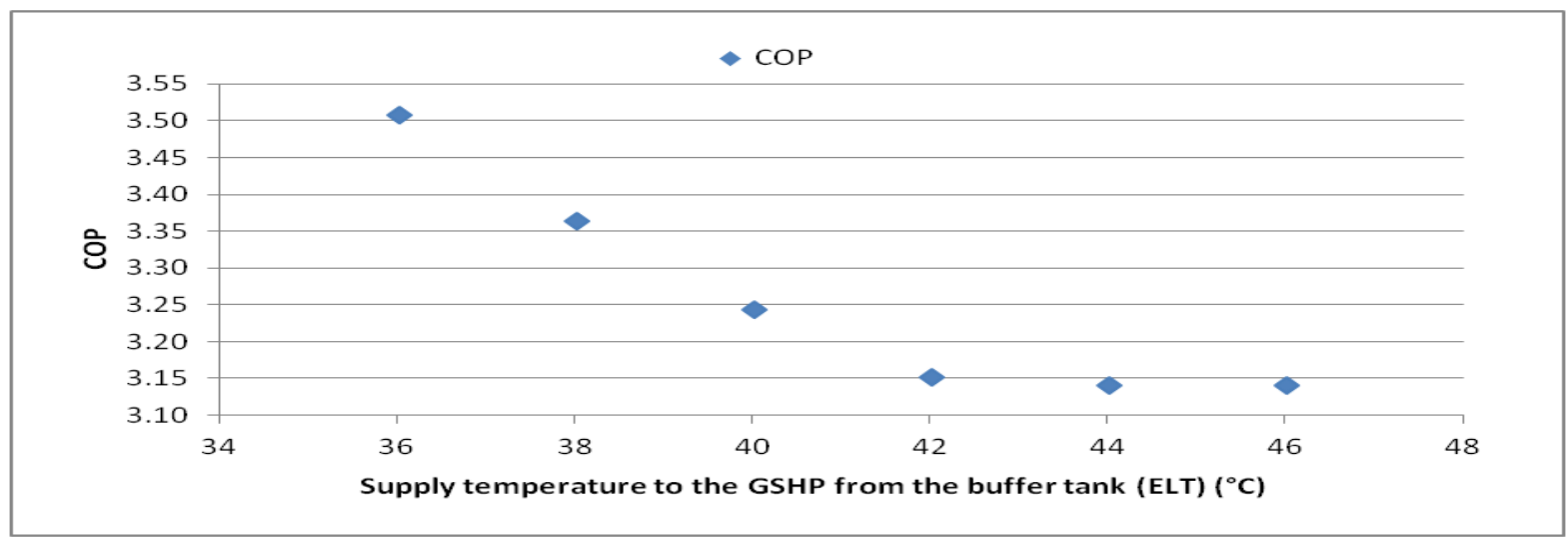

Figure 5.11 : COP vs. supply temperature from the buffer tank to GSHP

A better representation of the relation between the GSHP COP, Entering Load Temperature (ELT) and Entering Source Temperature (EST) is presented in Figure 5.12. As defined earlier, the ELT is the water temperature entering the GSHP from the buffer tank and the EST is the antifreeze mixture temperature entering the GSHP from the ground loop. High EST increases the heating COP whereas the high ELT decreases the heating COP. It is clearly noticed that the smaller the difference between the EST and the ELT improves the overall COP of the system. The smallest difference in the graph is $37^{\circ} \mathrm{C}$ when the EST and the ELT are $3.5^{\circ} \mathrm{C}$ and $40.5^{\circ} \mathrm{C}$, respectively. In this case, the highest COP (3.15) is reached. The lowest COP on the graph is around 2.7 where the highest temperature difference, $44.5^{\circ} \mathrm{C}$, between the $\mathrm{EST}, 0.5^{\circ} \mathrm{C}$, and the ELT, $45^{\circ} \mathrm{C}$, is recorded.

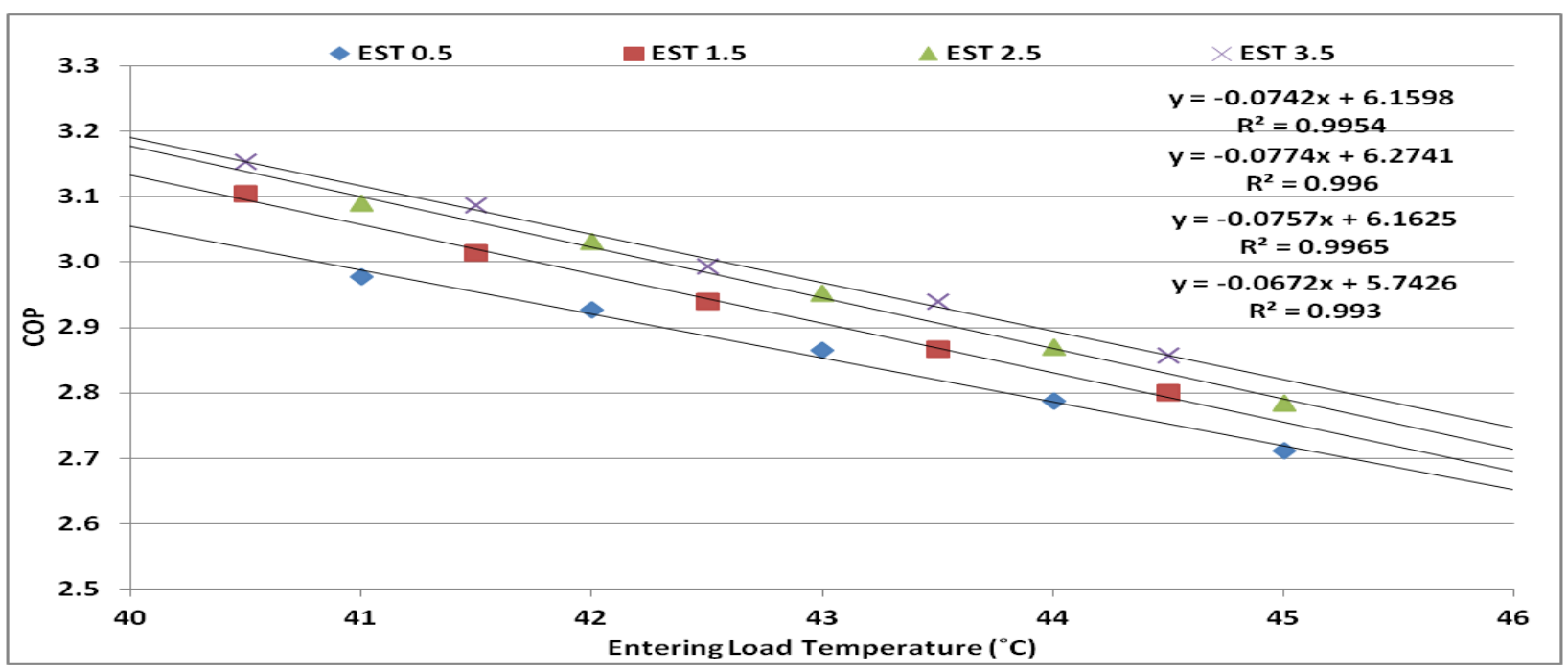

Figure 5.12 : GSHP COP vs. EST and ELT 


\subsubsection{Heat extraction from the ground}

The daily heat extraction from the vertical ground loops are shown in Figure 5.13. From the data collected from the vertical ground loops, the average daily heat extraction when operating in is $7.9 \mathrm{kWh}$ from both loops. Figure 5.13 shows that the heat extraction from the vertical ground loops is high when the daily average outdoor temperature is low and there is no heat extraction on May $31^{\text {st }}$ and June $2^{\text {nd }}$ when the daily average outdoor temperature is around $26^{\circ} \mathrm{C}$.

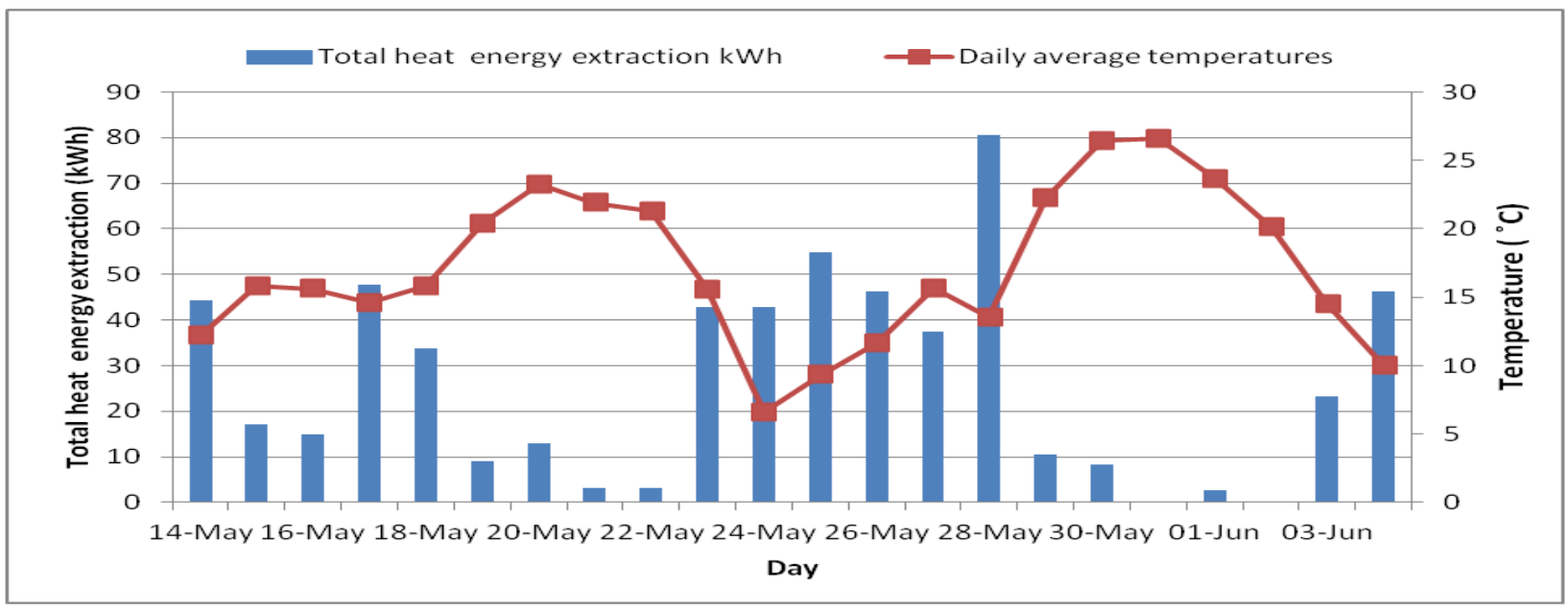

Figure 5.13 : Heat extraction from the vertical ground loops and daily average outdoor temperature 


\subsubsection{Cooling mode using the vertical loops (June 21 - July 8, 2013)}

In this period, the cooling mode of the GSHP and the vertical loops was investigated. The highest outdoor temperature recorded was $35^{\circ} \mathrm{C}$ and the lowest was $15^{\circ} \mathrm{C}$ with an average outdoor temperature of $24^{\circ} \mathrm{C}$ over the period. In this part, the two vertical loops were used with equal flow in both of them. When operating, the flow rate in both loops was constant with 24 LPM (6.3 US GPM) in each loop. The GSHP compressor, the ground-loop circulating pumps, and the GSHP to buffer-tank pump started at the same time when the temperature of the load (the water in the buffer tank) reached $15^{\circ} \mathrm{C}$ and stop when the temperature dropped to $5^{\circ} \mathrm{C}$. The flow rate of the water in the GSHP/buffer-tank loop was almost constant at around 50.4 LPM (13.3 US GPM) at all times. Those temperatures were based on the designed temperature of the Air Handling Unit (AHU) that is connected to the buffer tank. The buffer tank provides cold water to the house AHU that provides cooling to different zones of the house. As in the earlier case, an average daily representation will be used in this thesis and one operating cycle will be shown in Appendix C.2. As in the previous case, it is important to show the power draw of the different components with time, as the change in power draw has great influence on the performance of the system. The power draw of the different components of the system can be seen in a sample of operation taken on July $1^{\text {st }}, 2013$ in Figure 5.14.

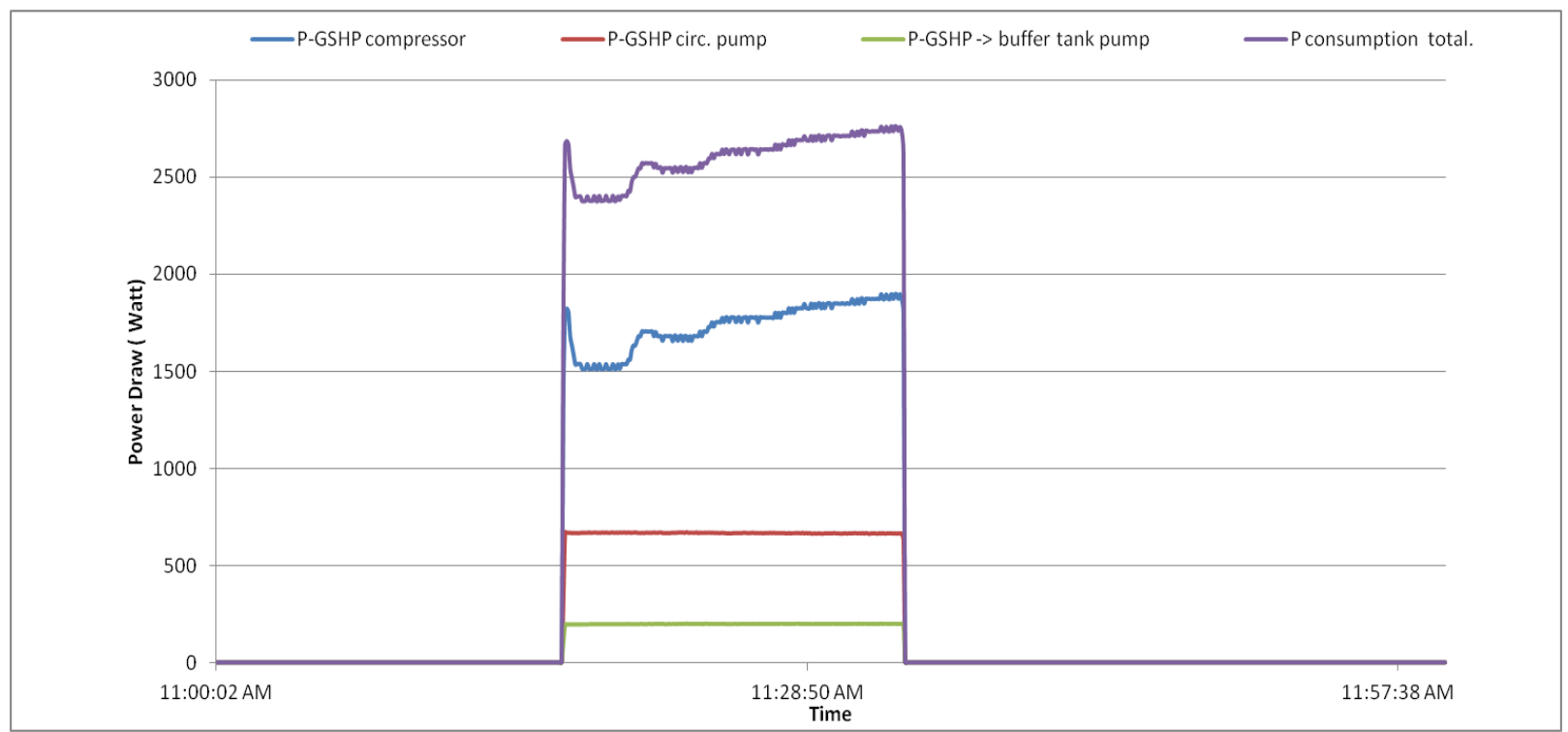

Figure 5.14 : Buffer-tank pump, ground-loop pumps, compressor and total power draw with time 


\subsubsection{Daily operation}

Figure 5.15 illustrates the GSHP system operation hours and the average daily outdoor temperature from June $21^{\text {st }}$ through July $8^{\text {th }}$. The COP of the GSHP was investigated considering the compressor, the circulating pumps and the buffer-tank pump operating hours and consumptions. In this part, the GSHP compressor accounted for $64 \%$ to $68 \%$ of the total power consumption which is almost $15 \%$ lower than the heating period. The reason for that is due to the lower temperature difference between the load and the sink. The total daily consumption and the daily cooling provided by the GSHP is illustrated in Figure 5.16. Figure 5.16 also illustrates a peak daily cooling and electricity consumption of $117 \mathrm{kWh}$ and $18 \mathrm{kWh}$ respectively at the highest daily average outdoor temperature of $28^{\circ} \mathrm{C}$.

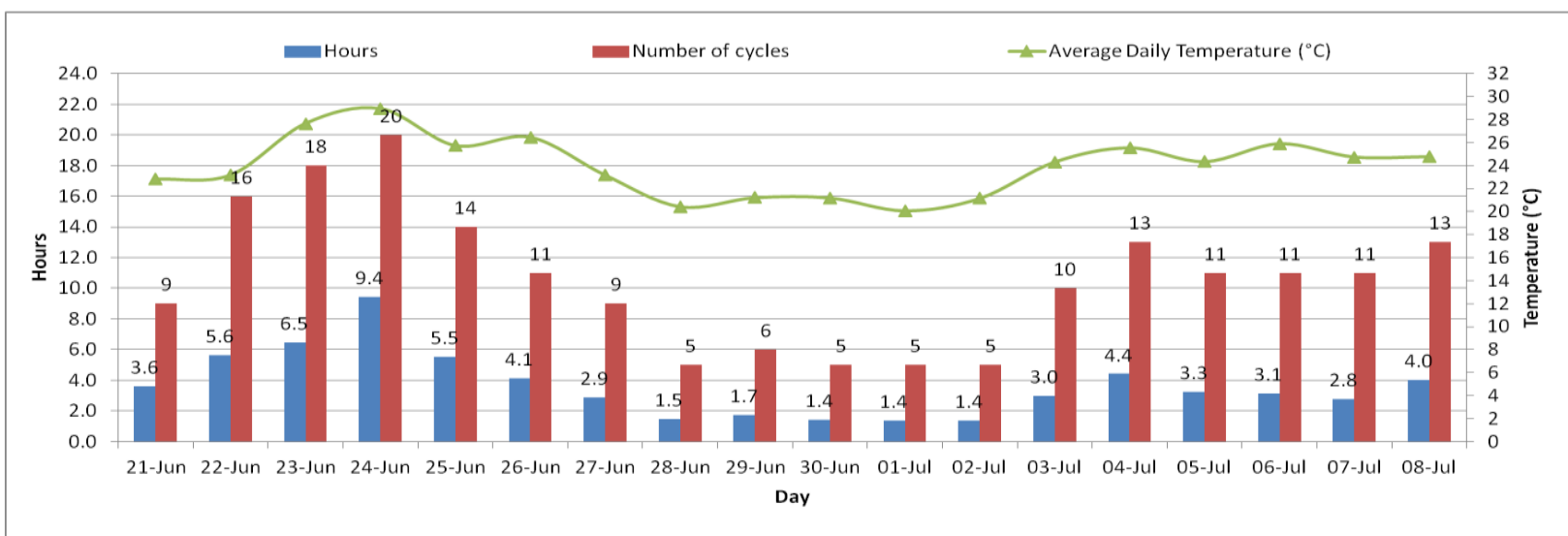

Figure 5.15 : Daily operating hours \& number of cycles of the GSHP system vs. daily average outdoor temperature

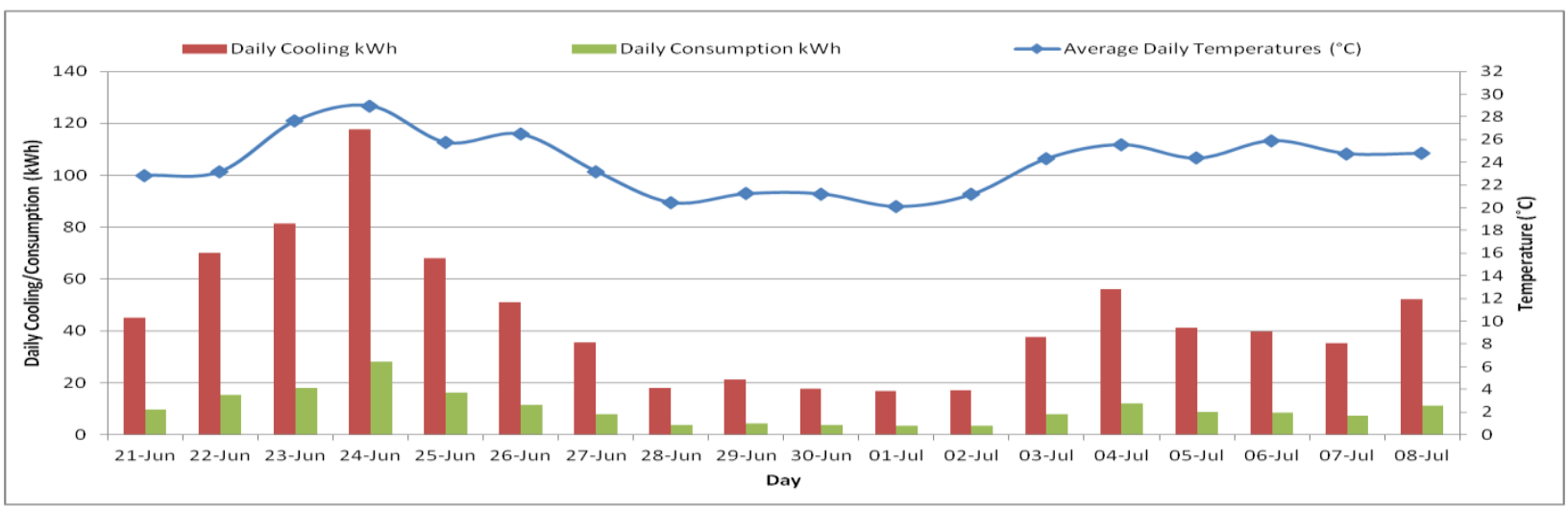

Figure 5.16 : Daily cooling and consumption of the GSHP system vs. daily average outdoor temperature 
Figure 5.17 shows the average daily coefficient of performance (COP). The coefficient of performance of the GSHP ranged from 4.2 to 4.8. As evident from the COP, the GSHP system is more efficient in cooling mode compared with to the heating mode in the first case. The higher efficiency is due to the lower temperature difference between the ELT and EST as will be explained in detail later. In the cooling mode, the GSHP system provides more than 4 cooling units for each unit of electricity consumed. The GSHP COP is expected to remain almost constant regardless of the outside temperature as it depends on the ground-loop and the load temperatures. However, it is noticed that there is small drop in performance of the GSHP around June $24^{\text {th }}$. It is clear that the higher the outside temperature is, the higher the daily operating hours and number of cycles of the GSHP system. The drop in the COP on that day and the small changes in the COP during the test period is because of the average operating hours of the GSHP during that period. On June $24^{\text {th }}$, the operating hours and the number of cycles of the GSHP system were 9.4 hours and 20 cycles giving an average of 28 minutes per cycle during that day. The longer cycle times in this test meant an increasing temperature difference across the GSHP which affected the COP. This longer period, compared to 16 minutes per cycle on July $2^{\text {nd }}$, lead to a lower COP of the system on June $24^{\text {th }}$. The increase of the temperature difference between the supply temperature to the GSHP from the vertical loops and the buffer tank can be seen in Figures C.5 and C.6 in Appendix C.

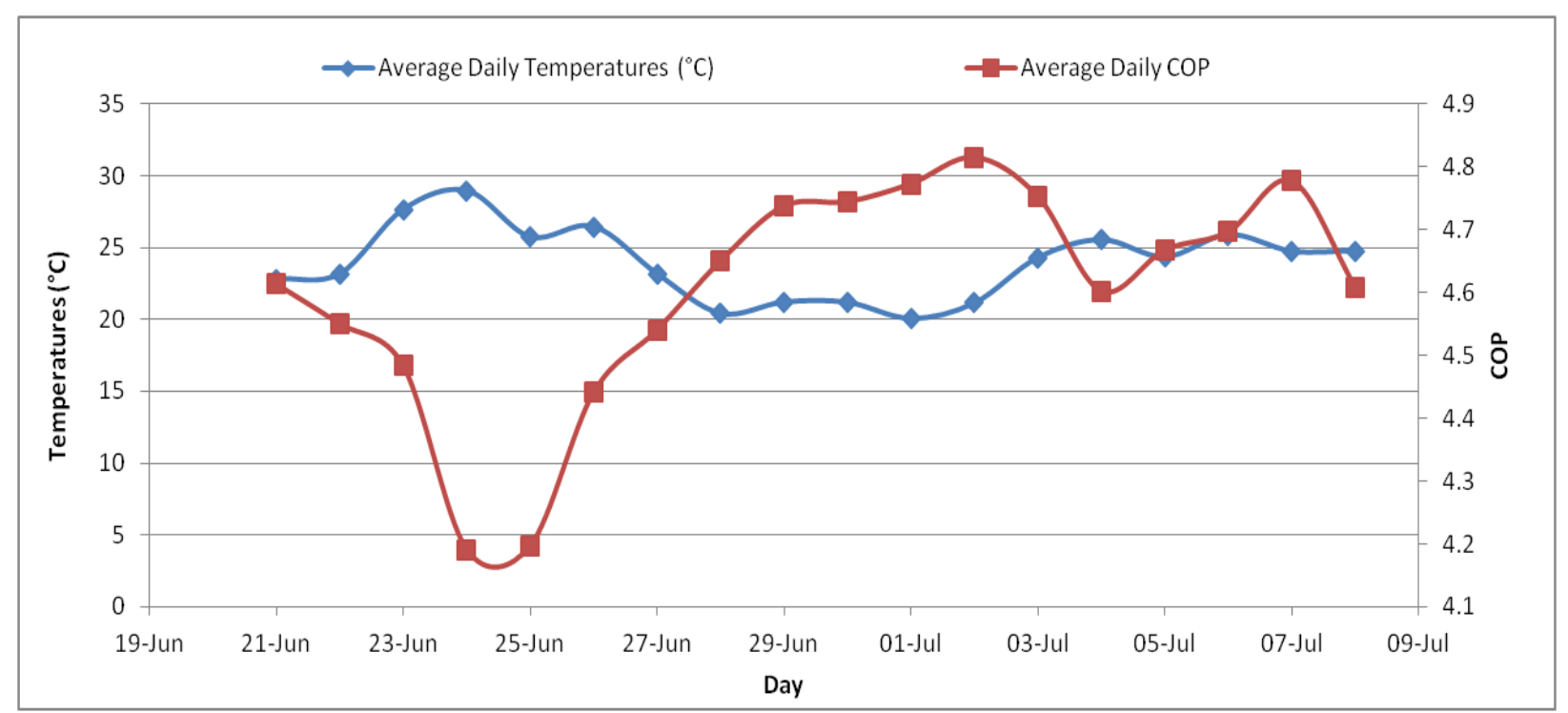

Figure 5.17 : Daily average COP of the GSHP system and daily average outdoor temperature 
Figure 5.18 shows the cumulative cooling and electricity consumption of the GSHP within this period. The total electricity consumption of the GSHP system during this test period turned out to be $182 \mathrm{kWh}$ and the total cooling was $823 \mathrm{kWh}$ which gives a test period COP of 4.5 which is higher than the GSHP specification (3.6-3.7). The higher COP is because the temperature supplied by the vertical ground loops is much lower than the manual uses which resulted in a better cooling performance. Also, comparing the cooling COP of this period (4.5) to the heating period COP (2.9) is an evidence of the role of the ELT and the EST on the COP, which will be explained at the end of this section.

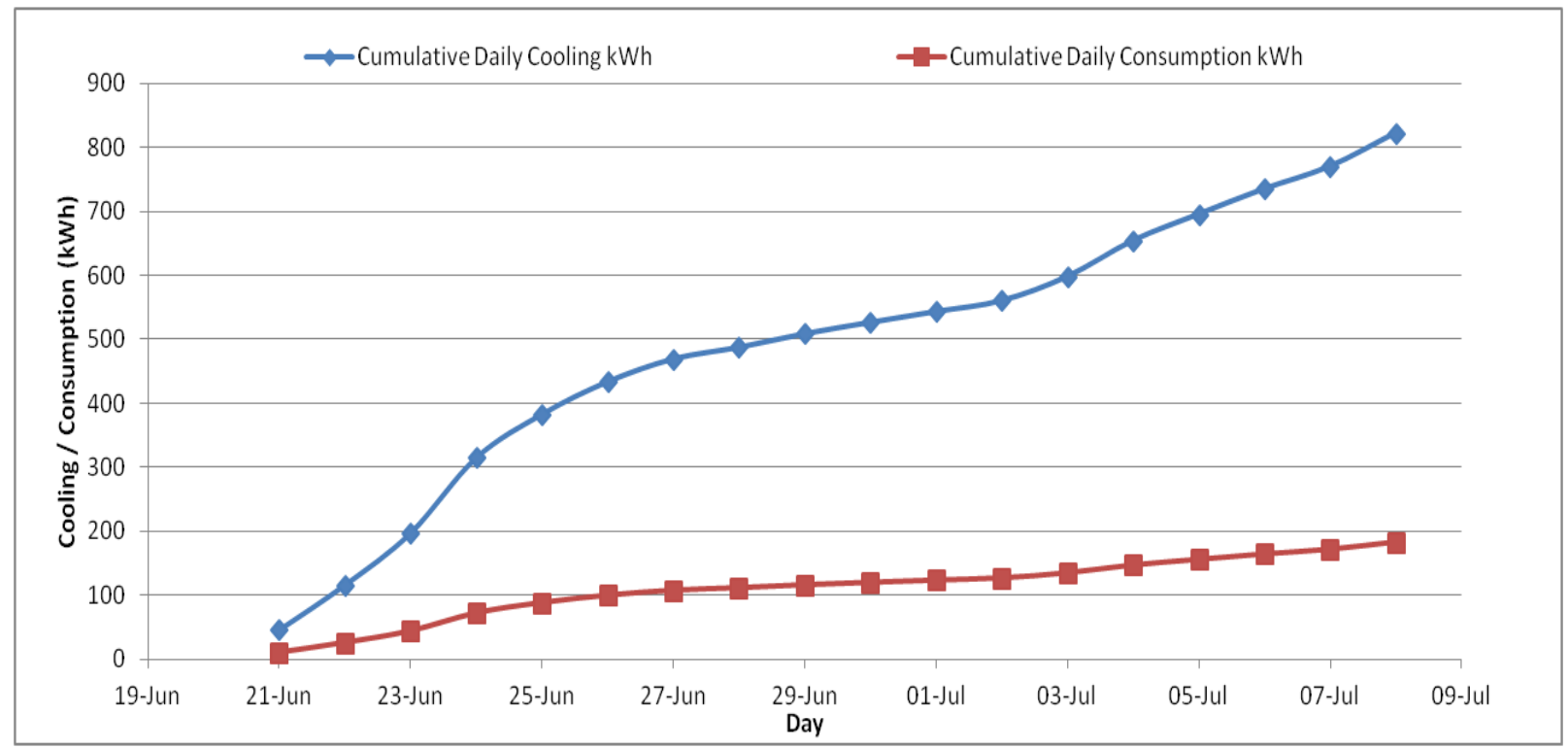

Figure 5.18 : Cumulative cooling and consumption of the GSHP system

The relationship between the daily cooling output and the electricity consumption with respect to the daily average outdoor temperature is shown in Figure 5.19. As the outdoor temperature increases, the demands for cooling increases resulting in longer operating hours and greater electricity consumption. Although the daily cooling output of the GSHP varies with the outdoor temperature, the daily electricity consumption has lower increasing rate with higher daily average outdoor temperature. 


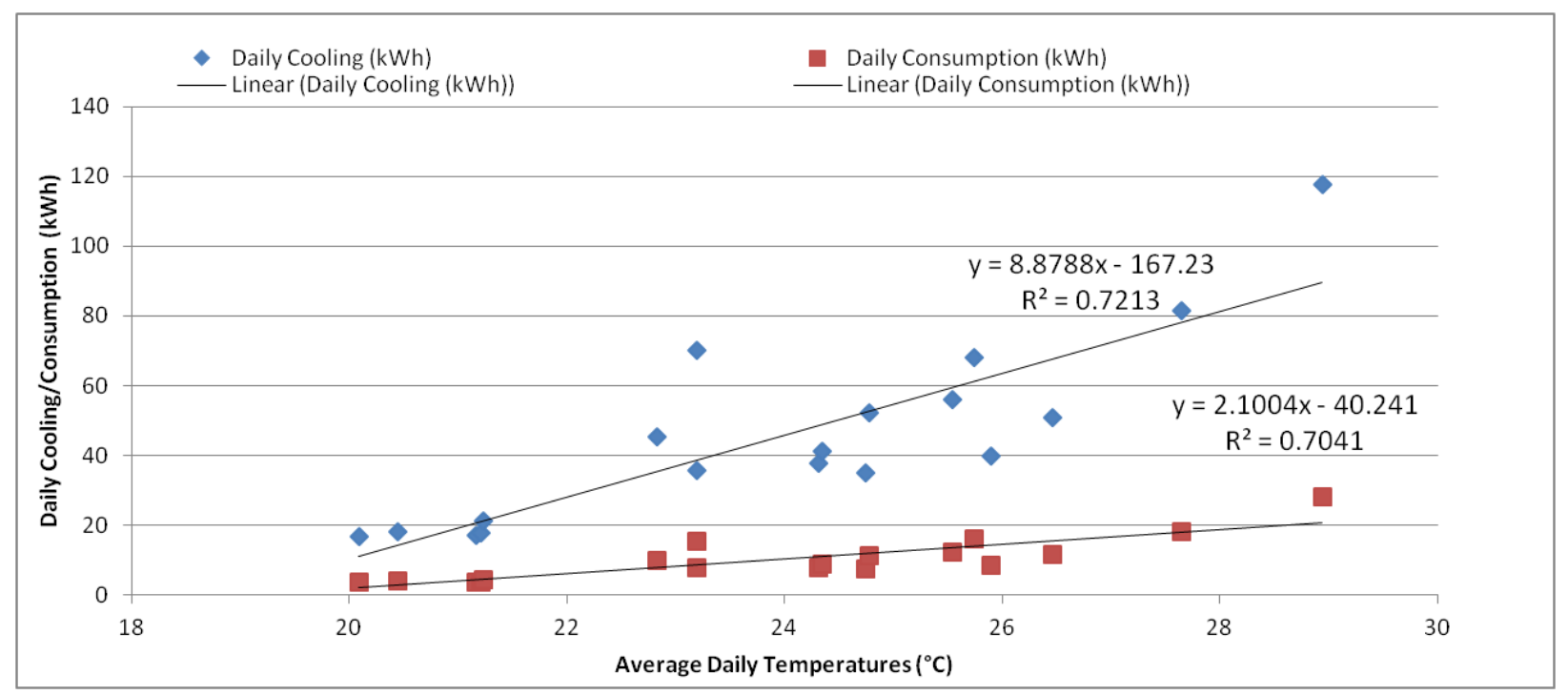

Figure 5.19 : Daily electricity consumption and cooling output vs. daily average outdoor temperature

\subsubsection{Entering Sink Temperature (EST) and Entering Load Temperature (ELT)}

As is always the case with GSHPs, the fluid return temperatures from the ground loop or EST have great influence on the performance of the GSHP system as seen in Figures 5.20-5.22. When in the cooling mode, the power draw by the GSHP system decreases as the EST decreases as seen in Figures 5.20. The higher the EST, more work is required by the compressor resulting in higher power draw. However, the cooling output from the GSHP system decreases as the EST increases as seen in Figures 5.21. Considering only the effect of the EST while the ELT is constant, the COP increases by almost $2 \%$ for each one degree Celsius decrease in the return fluid temperature. Figure 5.23 shows a good representation of the rate of change of cooling output, power draw and COP with respect to the change of the EST. 


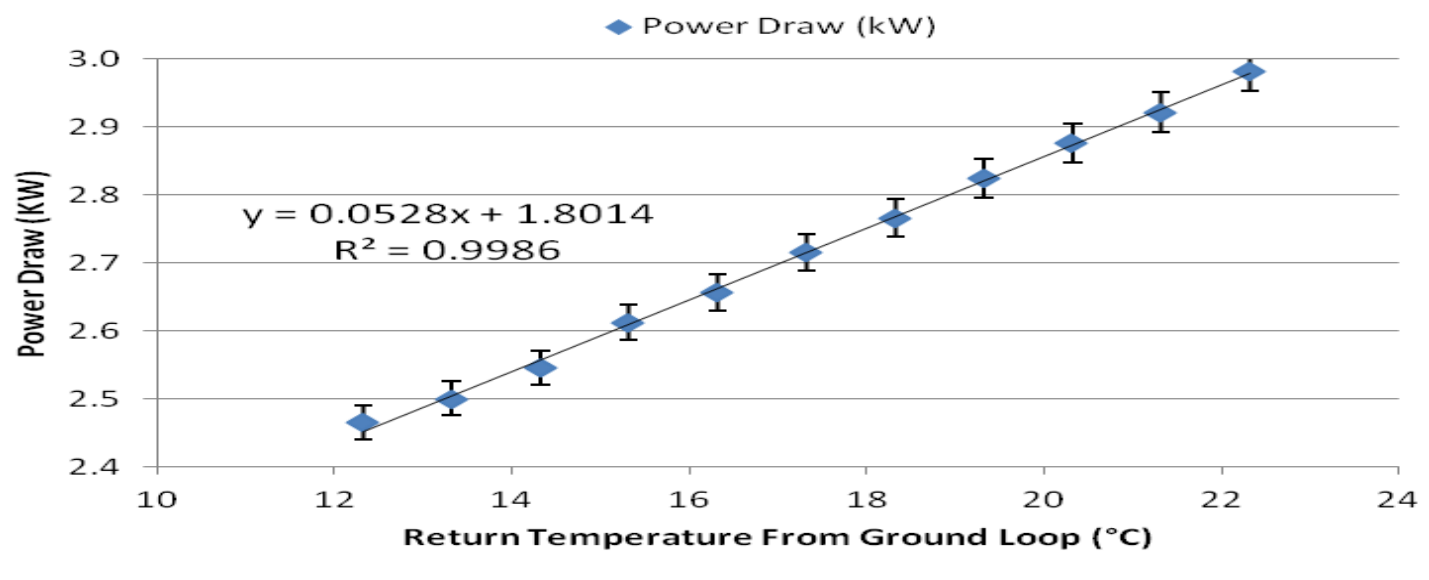

Figure 5.20 : Power draw vs. fluid return temperature from the ground loop

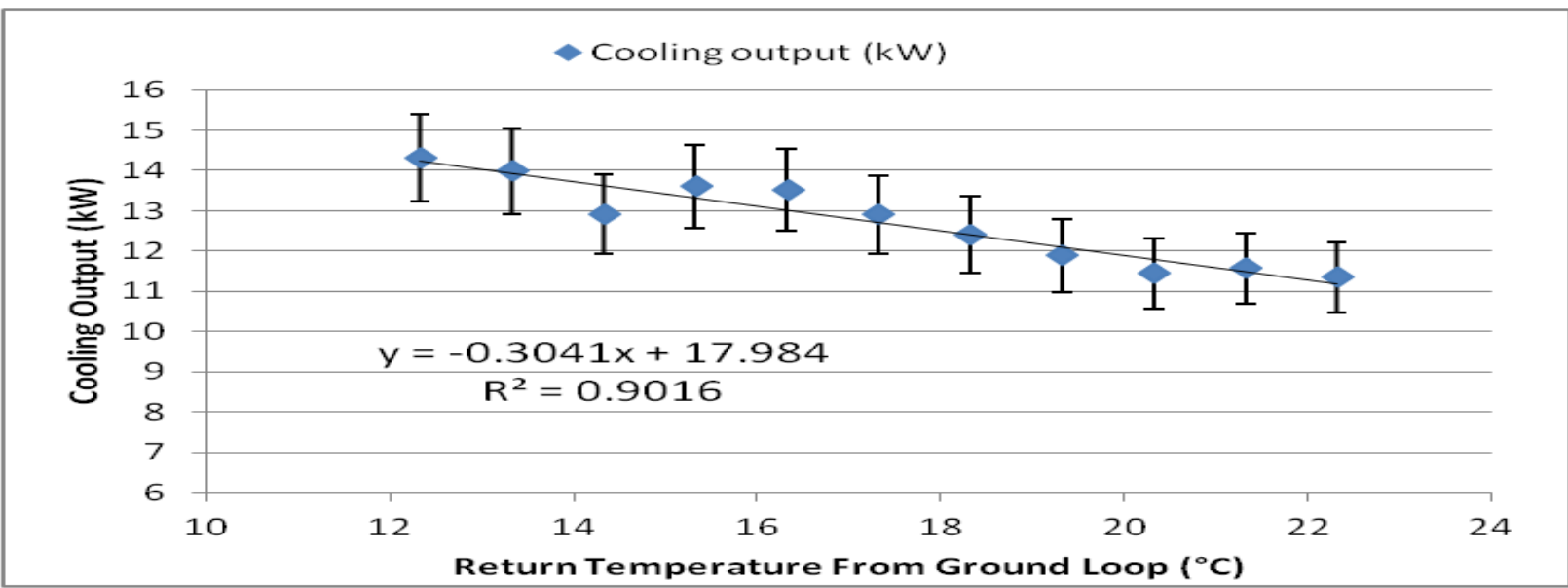

Figure 5.21 : Cooling output vs. fluid return temperature from the ground loop

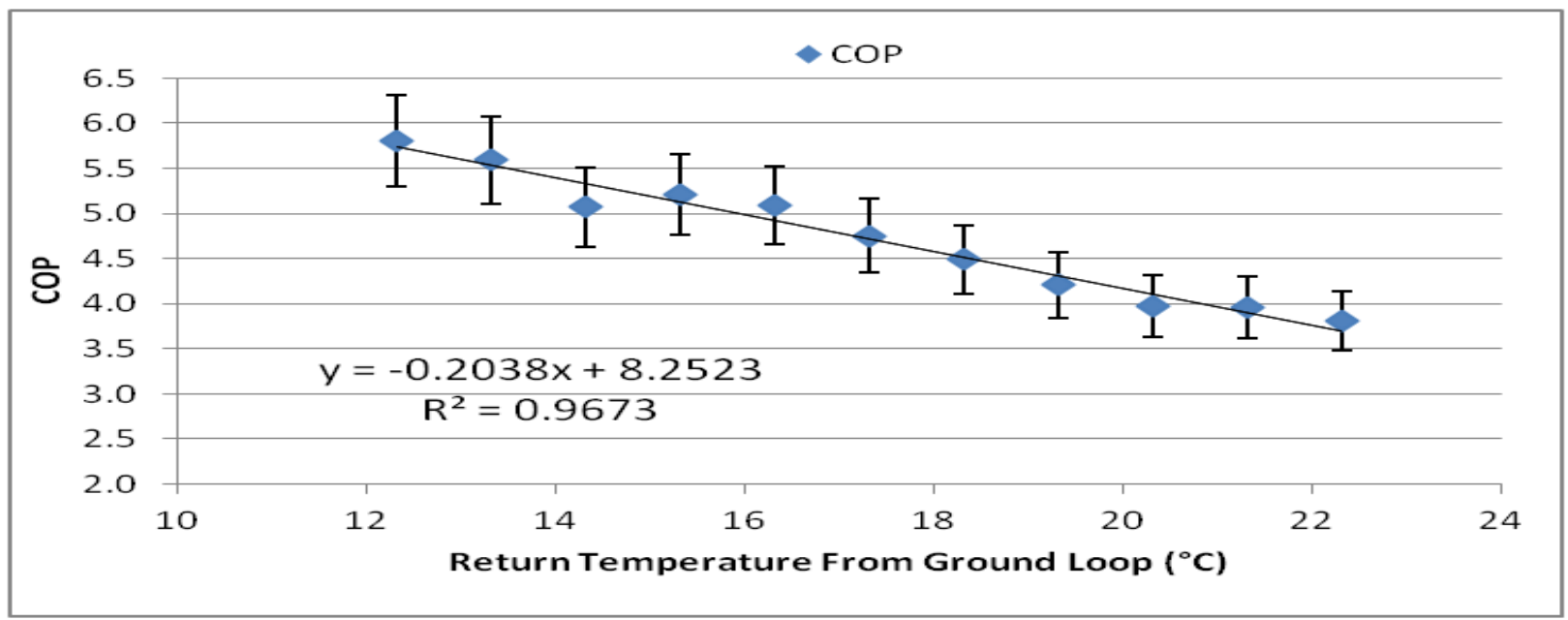

Figure 5.22 : COP vs. fluid return temperature from the ground loop 


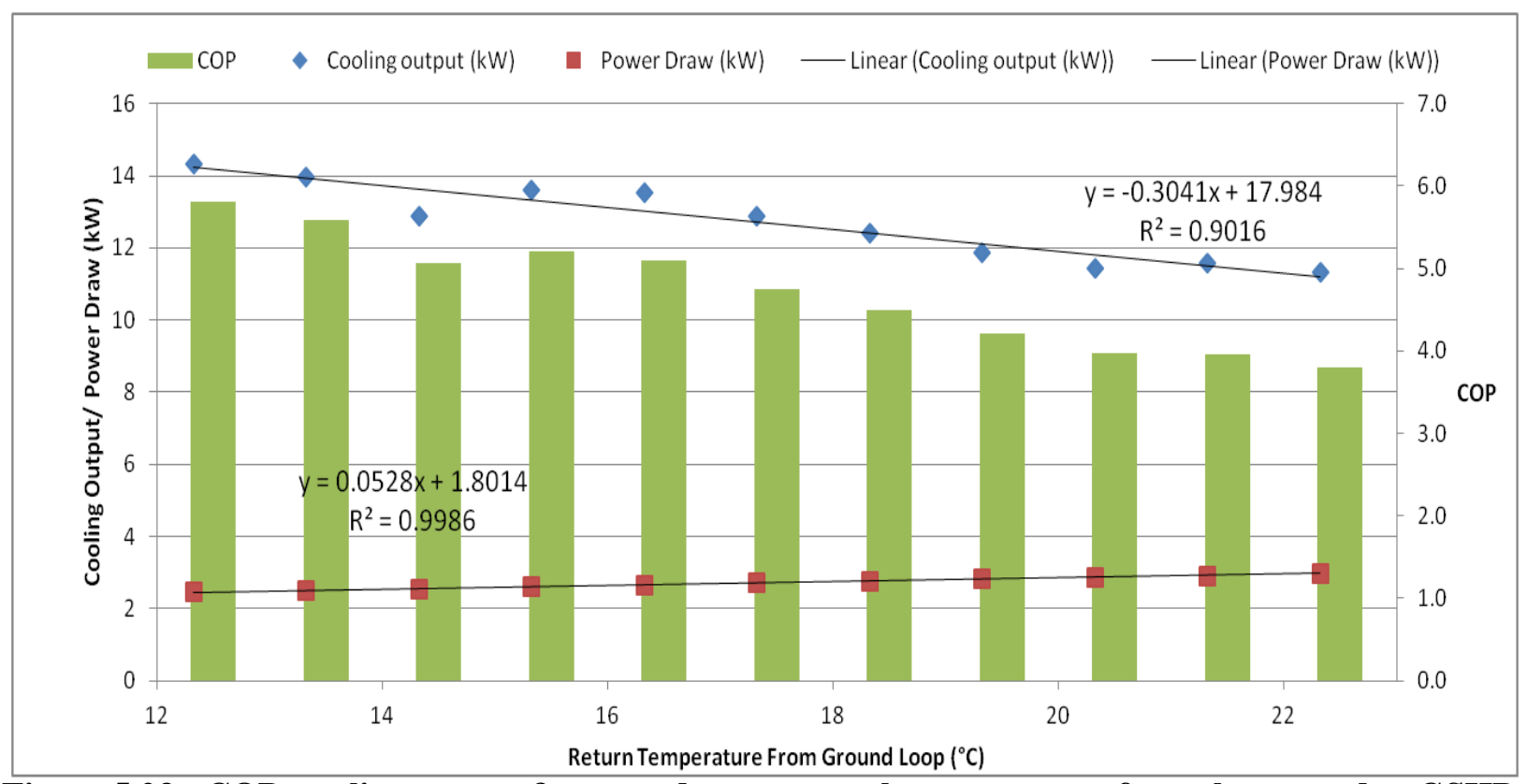

Figure 5.23 : COP, cooling output \& power draw vs. supply temperature from the ground to GSHP

Another important factor on the performance of the GSHP is the load temperature from the buffer tank. Figure 5.24 shows the cooling COP changes with the load temperature. The graph temperature axis is in reverse to give a better representation of the operation time line. The load temperature from the buffer tank starts at a high temperature and the GSHP keeps operating until the buffer tank temperature drops to around $5^{\circ} \mathrm{C}$. Assuming a constant EST, which averages around $17^{\circ} \mathrm{C}$, the decrease of the ELT results in a higher temperature difference between the EST and ELT. This increase in the temperature difference between the condenser side and the evaporator side force the compressor to draw more power for achieving the required compression effect. As a result, the performance of the GSHP system decreases with the decrease of the ELT. 


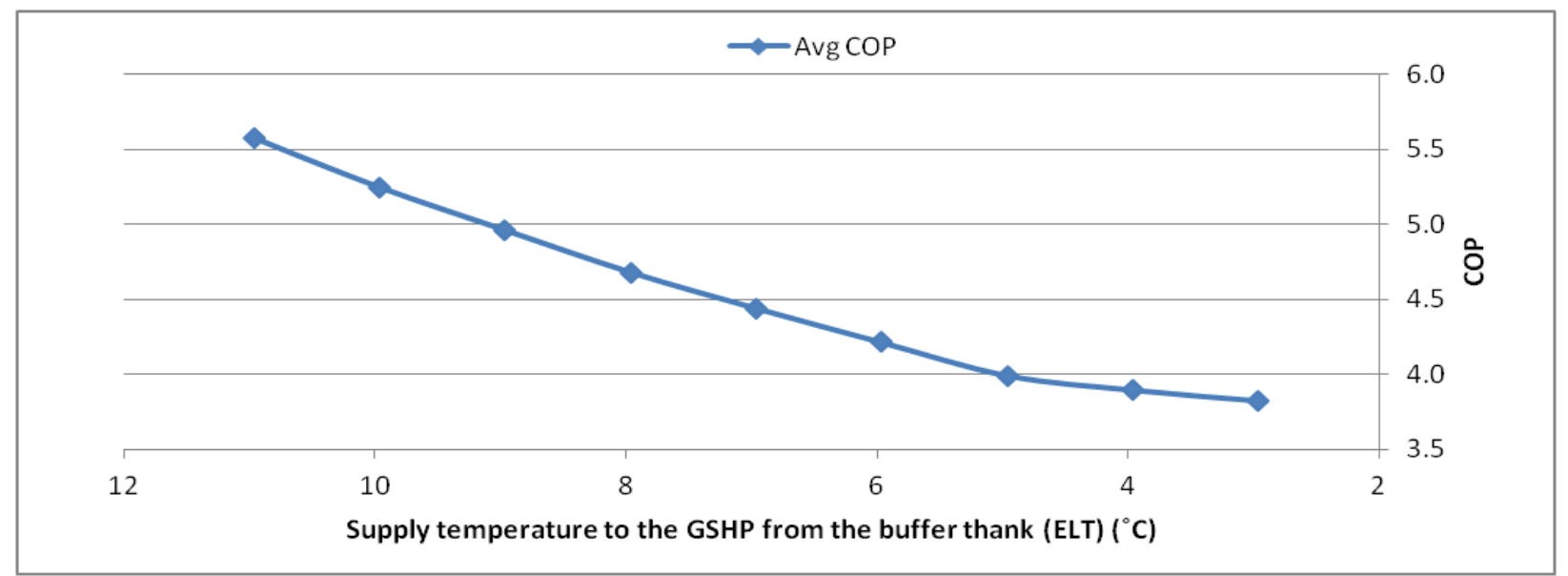

Figure 5.24 : COP vs. Supply temperature from the buffer tank to GSHP

The detailed heat pump COP is shown in Figure 5.25 at various entering sink and load temperatures. The increase of the sink temperature decreases the cooling performance of the GSHP. The increase of the load temperature, on the other hand, increases the cooling performance. Similar to the heating test, the smaller the difference between sink and load temperature, the higher the COP.

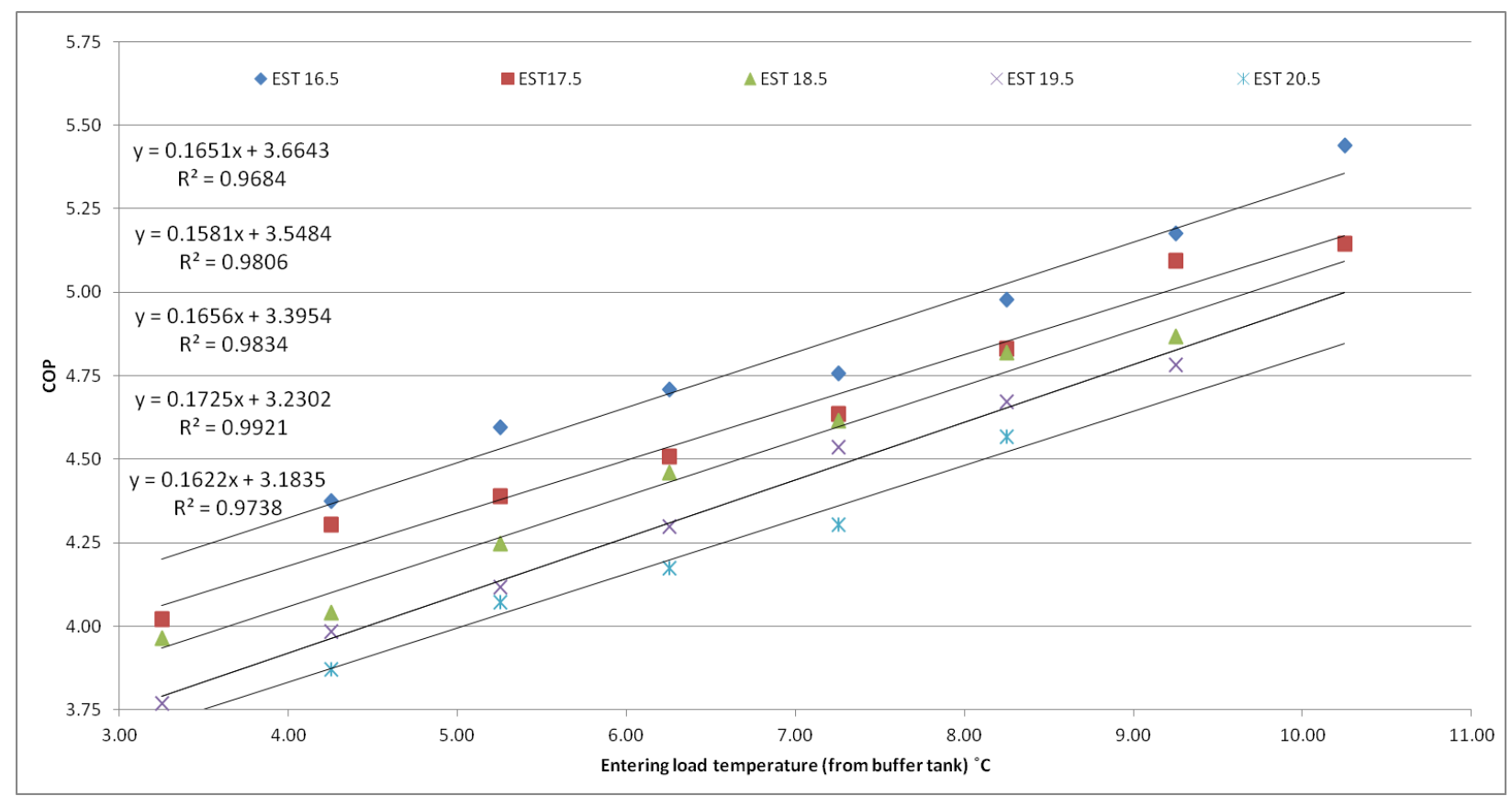

Figure 5.25 : GSHP COP vs. EST and ELT 


\subsubsection{Heat ejection to the ground}

The daily heat injection to the vertical ground loops are shown in Figure 5.26. From the data collected from the vertical ground loops, the average heat injection when operating is 14.4 kWh from both loops. Figure 5.26 shows that the heat ejection to the ground through the vertical loops increases with the increase of the average outdoor temperature. The peak heat injection occurred on the hottest day of the test period, June $24^{\text {th }}$.

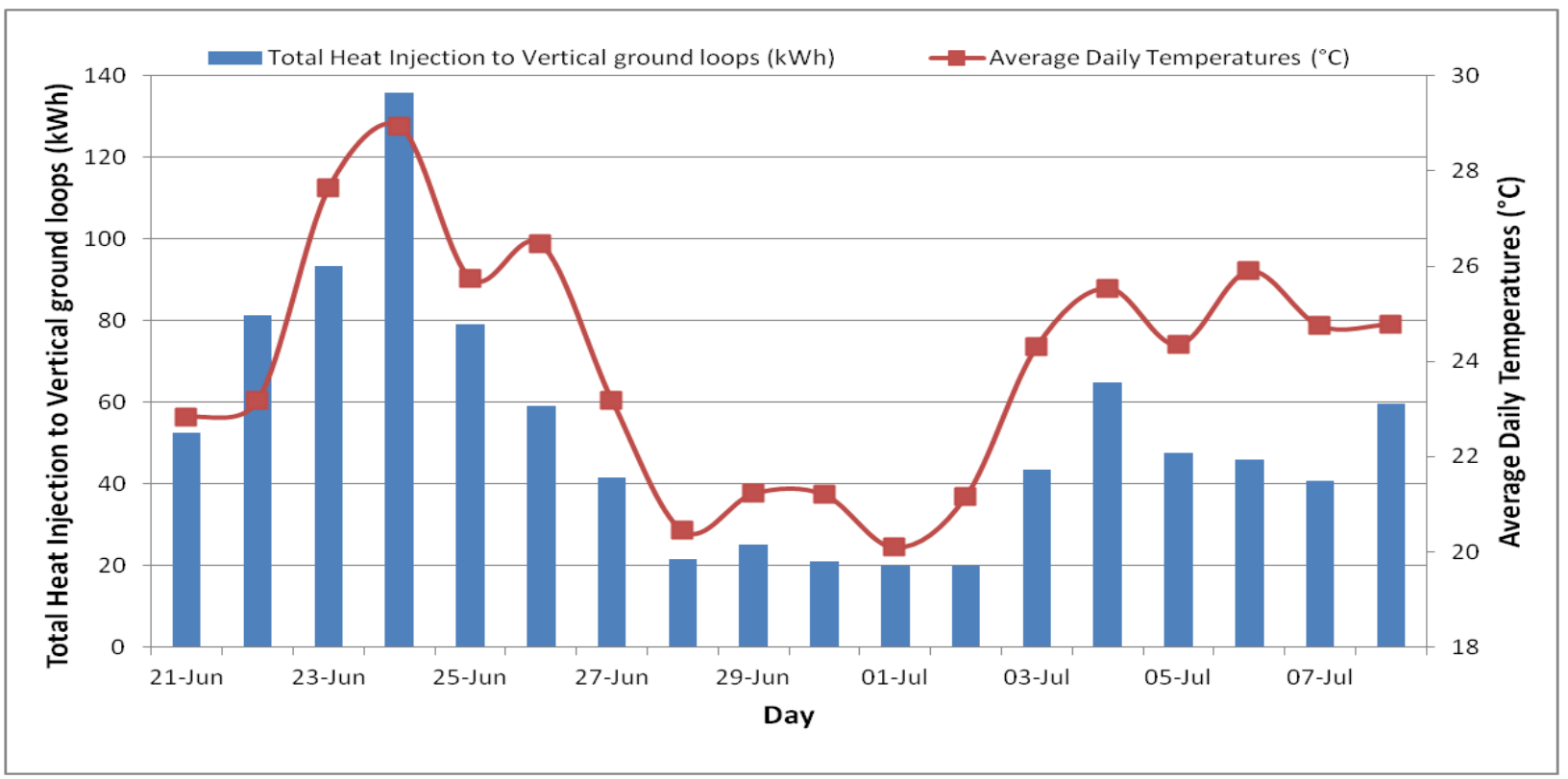

Figure 5.26 : Heat injection to the vertical ground loops and daily average outdoor temperature

\subsection{Vertical loops test summary}

In the first two tests, the GSHP operated using the vertical ground loops. The GSHP performed very well in the heating test period with a COP range of 2.7 (at an ELT of $45^{\circ} \mathrm{C}$ and EST of $0.5^{\circ} \mathrm{C}$ ) to 3.15 (at an ELT of $40.5^{\circ} \mathrm{C}$ and EST of $3.5^{\circ} \mathrm{C}$ ). In the cooling mode, the GSHP performed much better than in the heating mode with a COP range of 3.75 (at an ELT of $3^{\circ} \mathrm{C}$ and an EST of $19.5^{\circ} \mathrm{C}$ ) to 5.4 (at an ELT of $10.5^{\circ} \mathrm{C}$ and an EST of $16.5^{\circ} \mathrm{C}$ ). During both tests, the GSHP showed a constant performance which can be explained by a relatively constant ground temperature. Table 5.2 shows the summary of vertical loop test periods. 
Table 5.2 : Summary of the vertical loop test periods

\begin{tabular}{|c|c|c|c|c|c|}
\hline TEST & Loop used & Test period & $\begin{array}{c}\text { Heating/cooling Output } \\
(\mathrm{kWh})\end{array}$ & $\begin{array}{c}\text { Electricity Consumption } \\
(\mathrm{kWh})\end{array}$ & COP \\
\hline \multirow{2}{*}{ Heating } & Vertical loop & May 14- June 4, 2013 & 986.5 & 334.5 & 2.95 \\
\hline \multirow{2}{*}{ Cooling } & Vertical loop & June 21- July 8, 2013 & 823.0 & 182.0 & 4.5 \\
\hline
\end{tabular}

The overall performance of the GSHP is affected by the temperature difference between the EST and the ELT. The higher difference across the GSHP resulted in a lower COP. In the heating mode, the average difference between the EST and the ELT was around $41^{\circ} \mathrm{C}$ whereas in the cooling mode, the average difference was around $15^{\circ} \mathrm{C}$. The total power consumption of the GSHP is related to the EST and the ELT. The higher difference between the EST and the ELT resulted in a higher power draw. This change in the power draw is mainly due to the GSHP compressor since the power draw from the pumps is almost constant in all cases. The power draw of the ground-loop pumps is $670 \mathrm{~W}$, whereas from the GSHP/buffer-tank pump it is $190 \mathrm{~W}$. Due to the larger difference between the EST and the ELT in the heating mode, the GSHP compressor power draw usually starts around $2500 \mathrm{~W}$ and keeps increasing to over $4000 \mathrm{~W}$ at the end of most cycles. However, in the cooling mode, in which the difference between the EST and the ELT is smaller, the compressor power draw starts at around $1500 \mathrm{~W}$ and keeps increasing with time to approximately $2000 \mathrm{~W}$ at the end of most cycles. In both the heating and the cooling cases, the temperature difference between the EST and the ELT always increases with time as could be seen in Appendix C.1 and C.2. It is worth noting that the GSHP averaged of 32 minutes per cycle in the heating mode, whereas the cooling mode average was 20 minutes. Short and more frequent cycles in both tests were a result of the GSHP operating at part-load conditions. 


\section{-Both The Vertical and The Horizontal Loops}

\subsubsection{Cooling mode using the vertical and the horizontal loops with equal flow (July 19 -}

August 7, 2013)

From the beginning of the setup of the experiment, the horizontal loop was thought to have the same pipe size and length as the new vertical loop. However, after charging the horizontal loop with the water/PG solution, it turned out that the amount used was two times that of the water/PG solution used in the vertical loop to reach the desired concentration. Also, due to the lack of documentation on the size of the horizontal loop, the size was determined by measuring the total volume of the horizontal loop.

To do that, two samples from the horizontal loop were collected and sent for analysis. The first sample was taken with only the water/PG mixture in the loop. Then, a lithium sample was added to the loop with known concentration and volume and circulated in the loop. After a few days of circulation, the second sample was collected and sent for analysis. From the concentration of lithium in the second sample, the volume of the horizontal loop was calculated to be 732 L. Knowing the horizontal loop pipe size, it turned out that the horizontal loop is two times the length of the vertical loop. Appendix D shows the detailed test and the calculations of the horizontal loop lengths.

In this part of the experiment, the vertical and horizontal loops were connected to the GSHP and the flow was divided equally between them. The data collection started on July 10 , 2013. However, due to missing data and errors in the readings, the data in this section is presented from July 19 to August 7, 2013. The missing data and errors in the readings were a result of the huge amount of data collected in the house at that time and the limited computational and storage capabilities of the Central Processing Unit (CPU) and database used in the house. More frequent backup of the database and limiting the use of the data acquisition system (DAQ) for the remaining test period resulted in negligible missing data points and errors. 
During this part of the experiment, the ambient temperature range was between $10^{\circ} \mathrm{C}$ and $36^{\circ} \mathrm{C}$ with an average period temperature of $22^{\circ} \mathrm{C}$, which provided a good temperature range to analyze the cooling performance of the GSHP using both vertical and the horizontal ground loops. When operating, the flow rate in both the vertical and the horizontal loops were constant with 32 LPM (8.45 US GPM) in each loop. In this part, the GSHP starts when the temperature of the load (the water in the buffer tank) reaches $15^{\circ} \mathrm{C}$ and stops when the temperature drop to $5^{\circ} \mathrm{C}$. The flow rate of the water in the GSHP/buffer-tank loop was almost constant at around 47.3 LPM (12.5 US GPM) at all times. In Figure 5.27, the power draw of the different components of the GSHP is shown for one cycle.

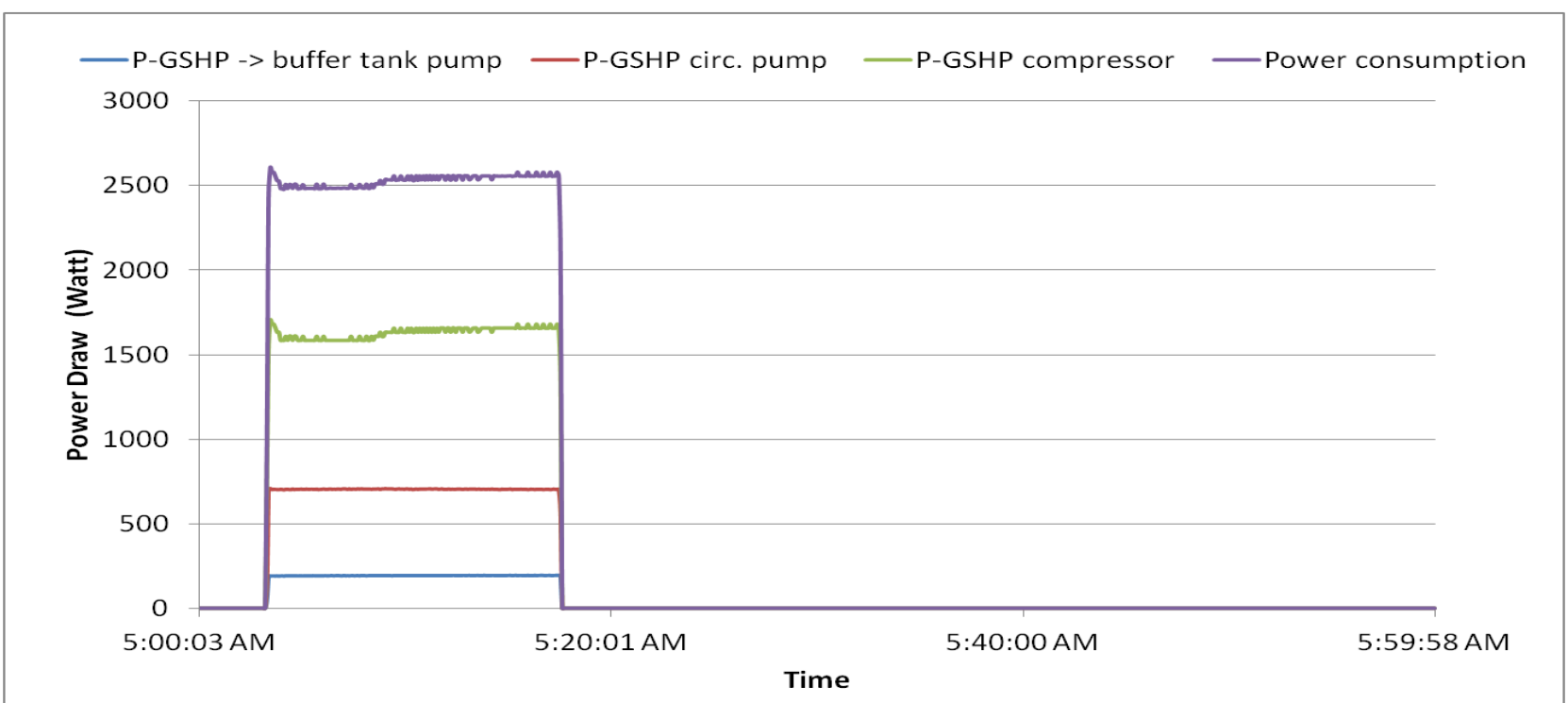

Figure 5.27 : Buffer-tank pump, ground-loop pumps, compressor and total power draw with time

\subsubsection{Daily operation}

The GSHP operation hours and the daily average outdoor temperature starting from July 19 to August 7, 2013 is presented in Figure 5.28. In this part, the GSHP compressor accounted for around $64 \%$ to $66 \%$ of the total power consumption. This percentage is much lower than the previous cases. As will be shown later, it is due to the lower difference between the EST and the ELT when using both the horizontal and the vertical loops together. Figure 5.29 shows the total daily consumption and the daily cooling provided by the GSHP and illustrates a peak daily 
cooling and electricity consumption of $97 \mathrm{kWh}$ and $18.2 \mathrm{kWh}$ respectively at the highest daily average outdoor temperature of $29^{\circ} \mathrm{C}$.

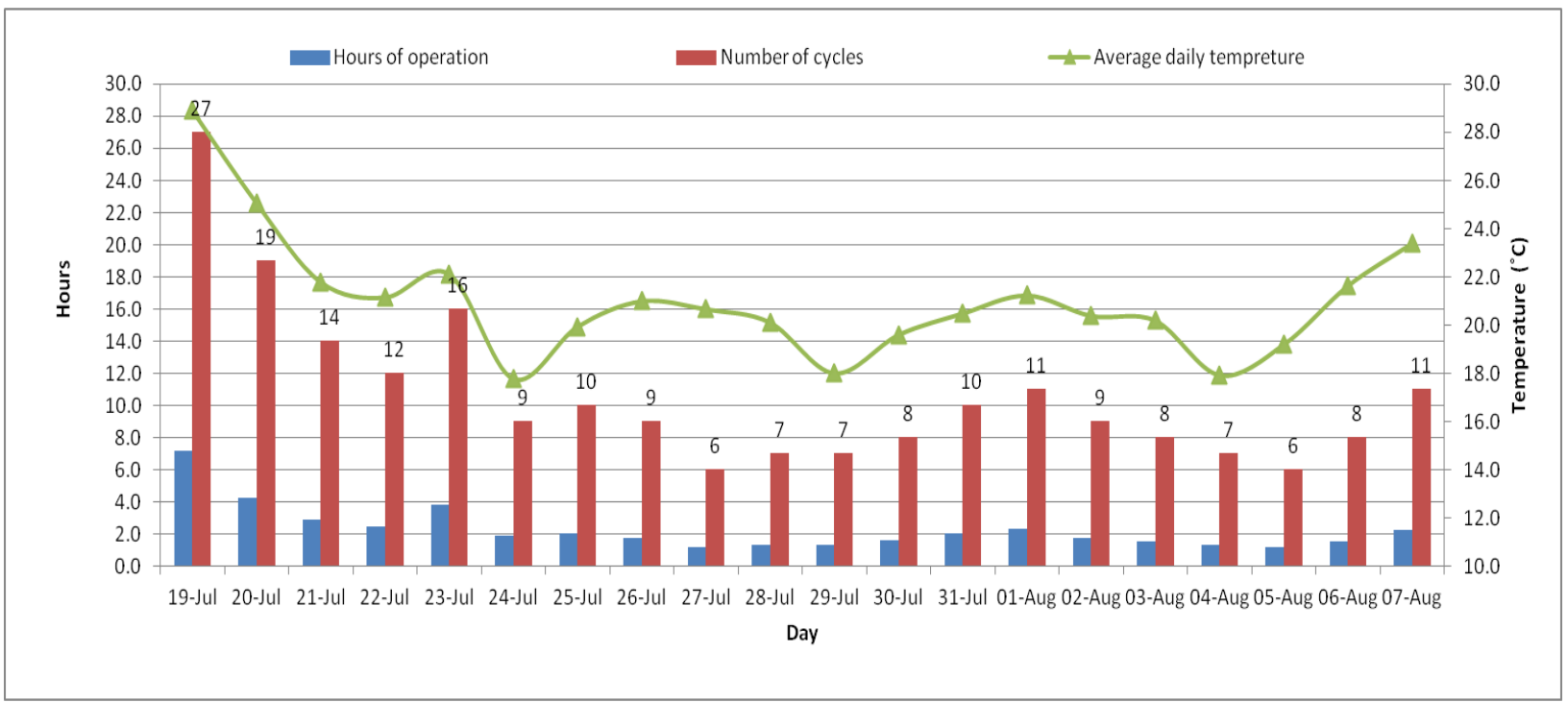

Figure 5.28 : Daily operating hours \& number of cycles of the GSHP system vs. daily average outdoor temperature

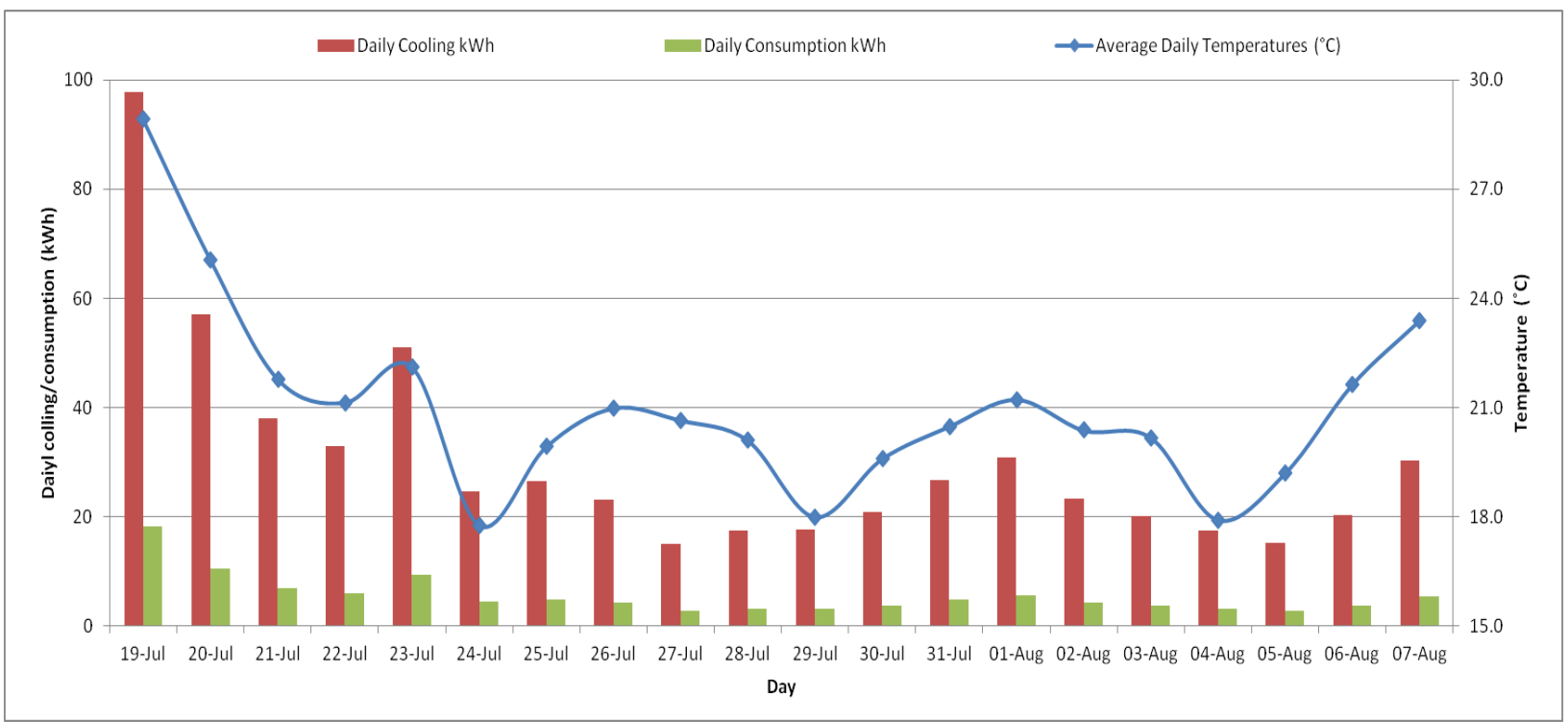

Figure 5.29 : Daily cooling and consumption of the GSHP system vs. daily average outdoor temperature

Figure 5.30 shows the daily COP. The daily COP is higher than in the previous cases with a range between 5.36 and 5.48. As in the previous cases, the GSHP COP remains almost 
constant regardless of the outside temperature. Although the change in the daily COP is small throughout the test period, the lowest daily COP value was recorded on July $19^{\text {th }}$. During the test period, it was noticed from the data that the daily average cycles time is $11 \pm 1$ minutes while on July $19^{\text {th }}$ the average daily cycle time was 16 minutes. This longer period lead to higher power draw by the GSHP compressor resulting in the lower COP. Also, the number of cycles on July $19^{\text {th }}$ has magnified this effect of cycling time.

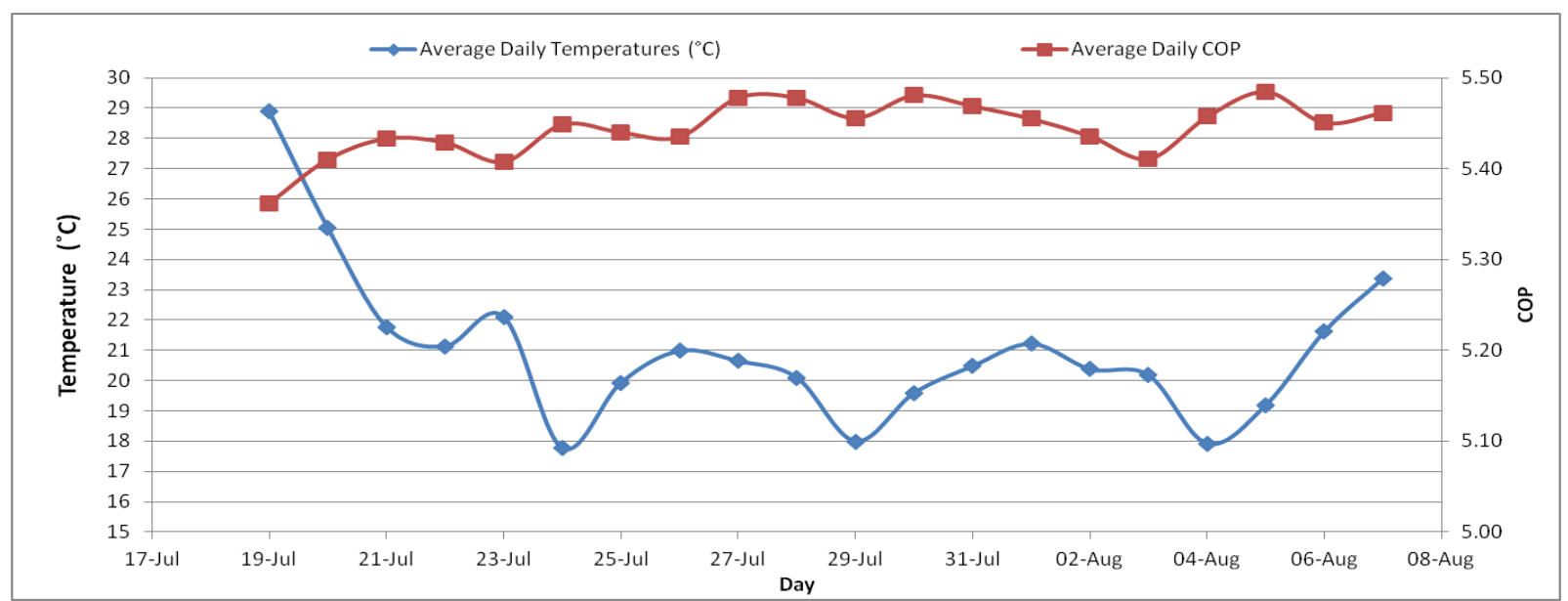

Figure 5.30 : Daily average COP of the GSHP system and daily average outdoor temperature

Figure 5.31 shows the cumulative cooling and electricity consumption of the GSHP within this period. The total electricity consumption of the GSHP system during this test period turned out to be $112 \mathrm{kWh}$ and the total cooling was $607 \mathrm{kWh}$, which resulted a test period COP of 5.42. This high COP is much higher when compared to the cooling mode COP (4.5) in Section 5.1.2. Figure 5.32 shows the relationship between the daily cooling output and the electricity consumption with respect to the average daily outdoor temperature. As the outdoor temperature increases, the demands for cooling increase resulting in higher operating hours and electricity consumption. 


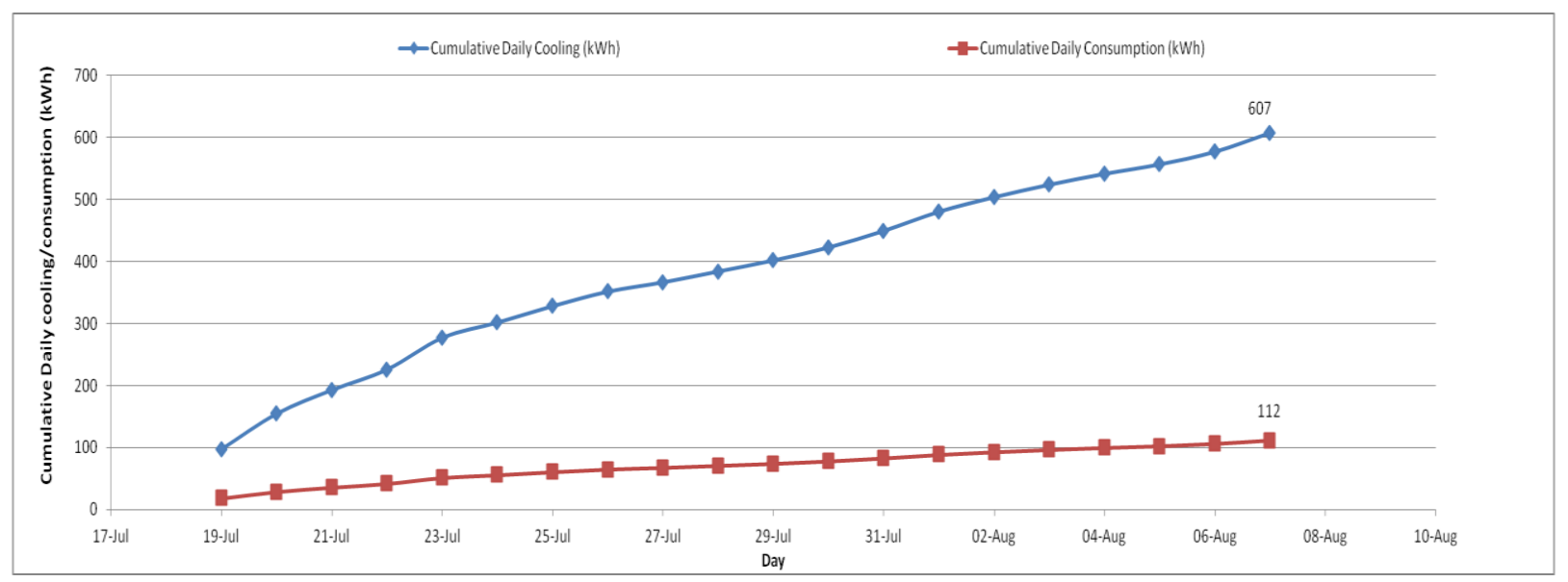

Figure 5.31 : Cumulative cooling and consumption of the GSHP system

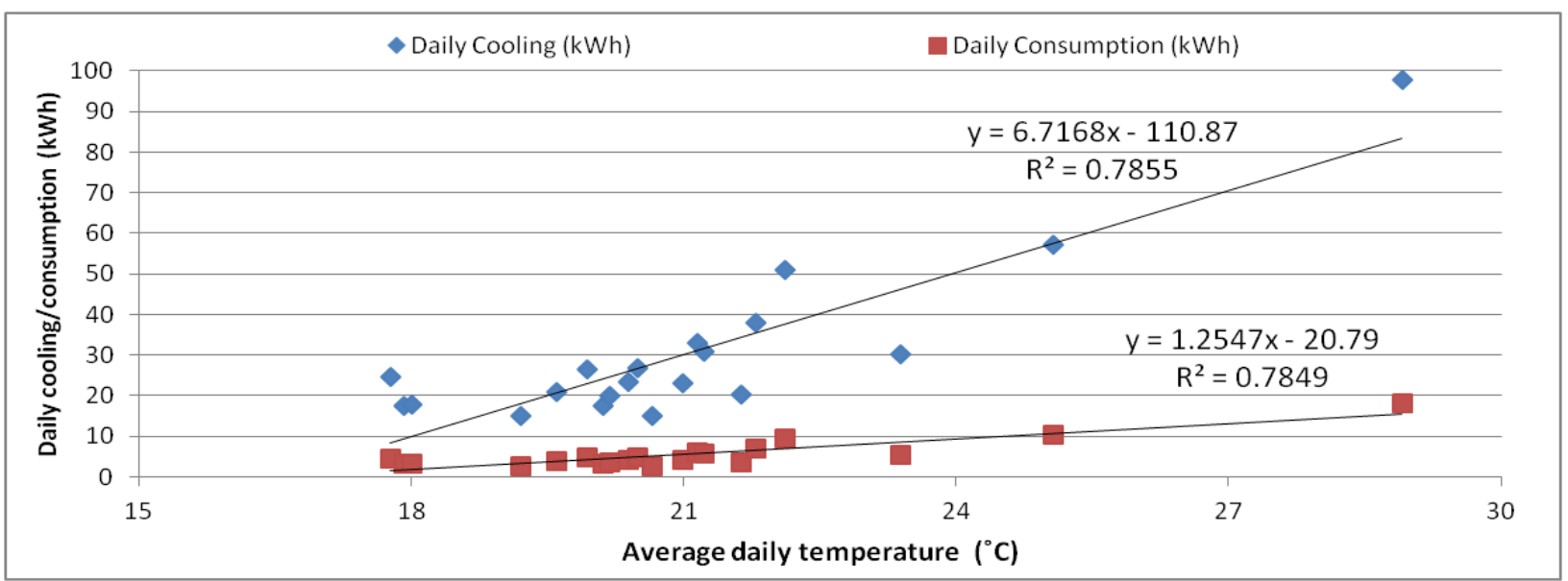

Figure 5.32 : Daily electricity consumption and cooling output vs. average daily outdoor temperature

\subsubsection{Entering Sink Temperature (EST) and Entering Load Temperature (ELT)}

The EST influence on the performance of the GSHP system can be seen in Figures 5.335.35. In cooling mode, the power draw by the GSHP system increases as the EST increases as shown in Figures 5.33. However, as in the previous cooling test, the cooling output from the GSHP system decreases as the EST increases which can be seen in Figures 5.34. Also, the COP of the GSHP is effected by the EST. As seen in Figure 5.35, the COP decreases as the EST increases. The COP drops by almost $3 \%$ for reach one degree Celsius increase in the EST. Figure 5.36 shows complete representation of the change of cooling output, power draw and COP with respect to the change of the EST. 


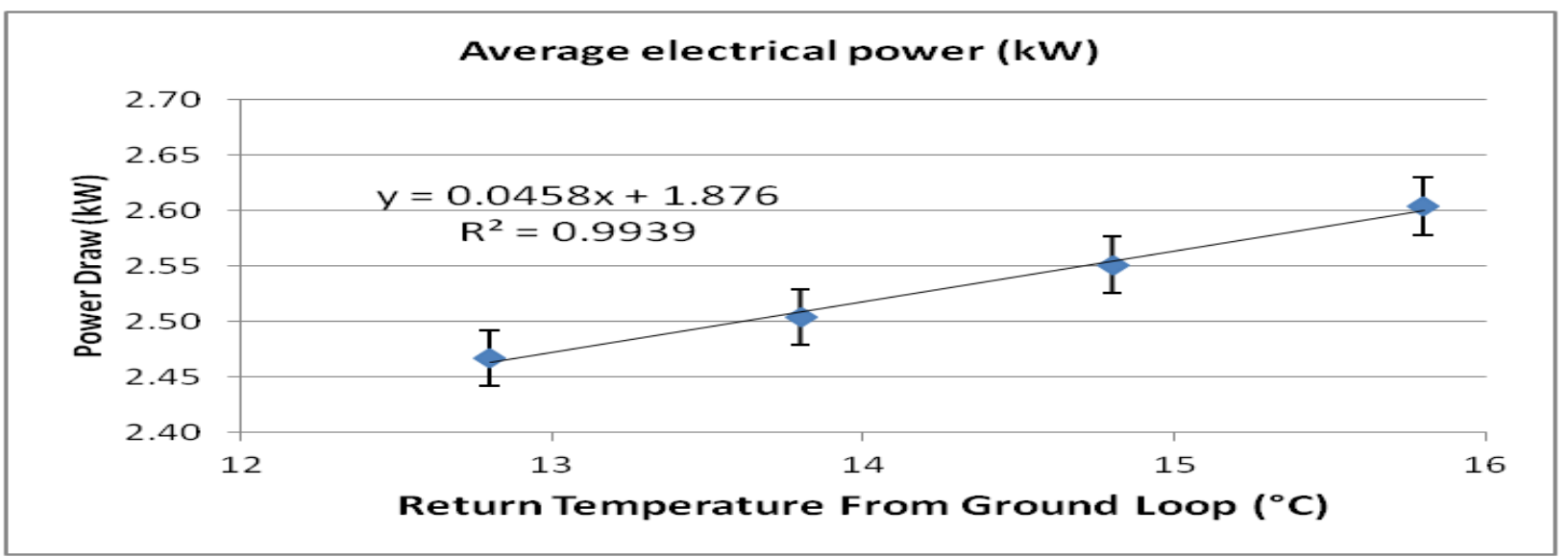

Figure 5.33 : Power draw vs. fluid return temperature from the ground loop

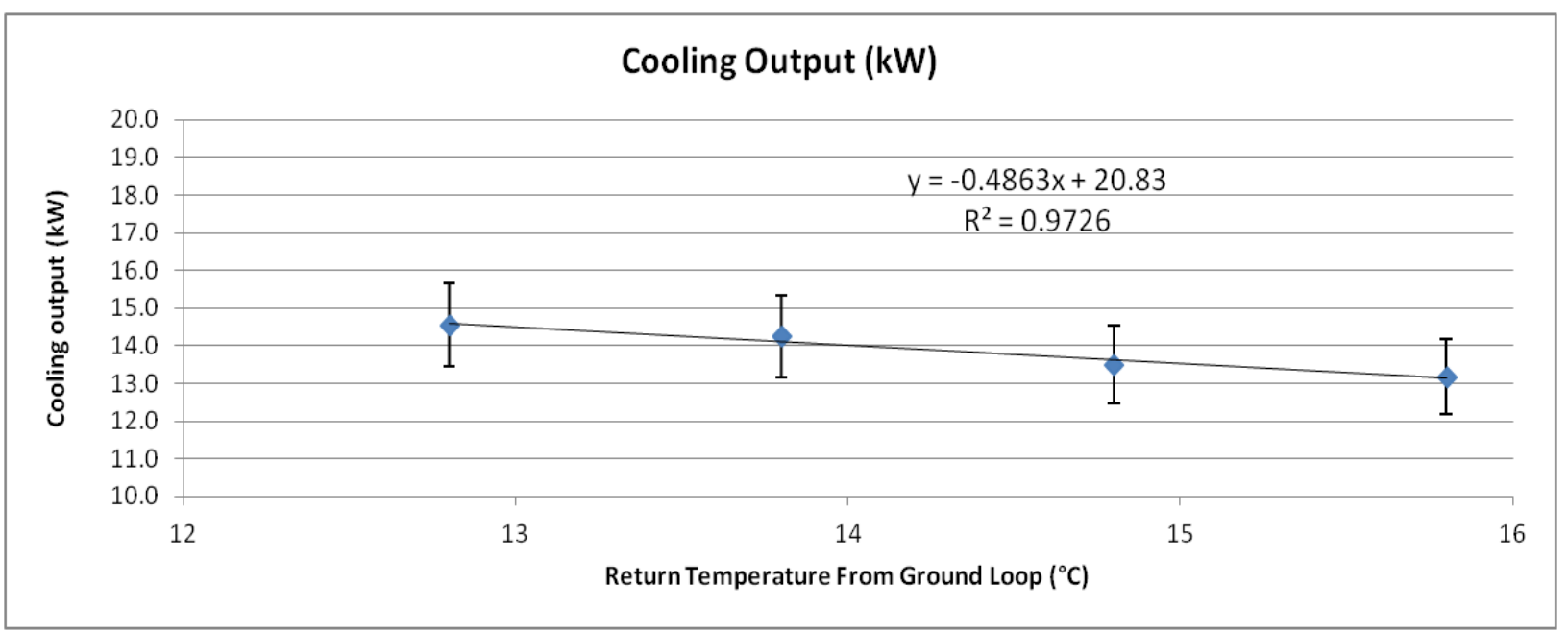

Figure 5.34 : Cooling output vs. fluid return temperature from the ground loop

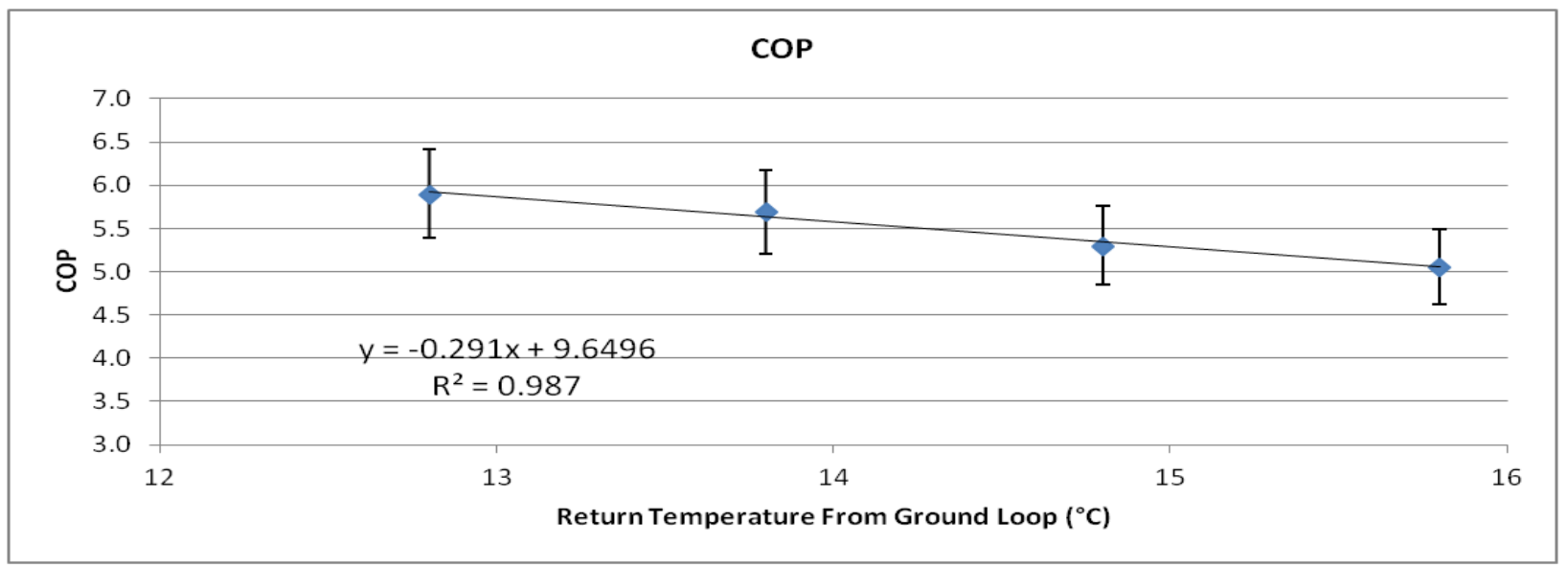

Figure 5.35 : COP vs. fluid return temperature from the ground loop 


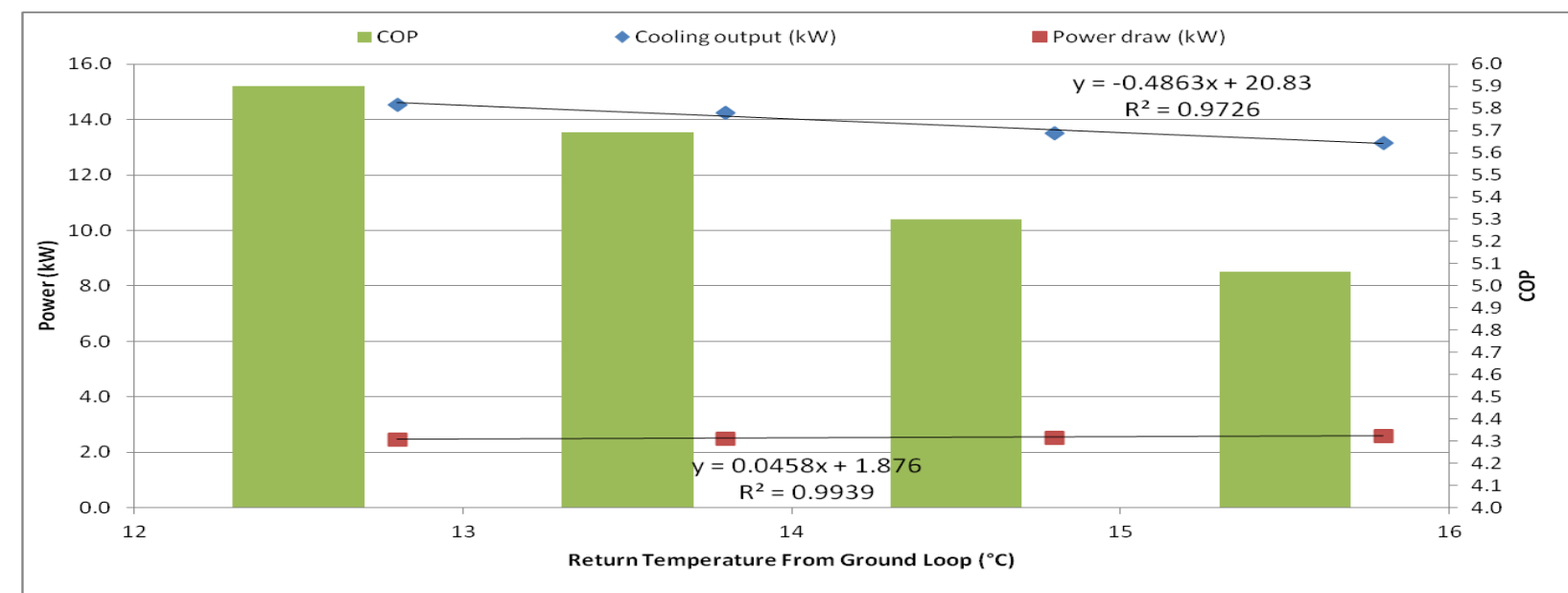

Figure 5.36 : COP, cooling output \& power draw vs. supply temperature from the ground to GSHP

The change of the performance of the GSHP with different ELT is seen in Figure 5.37. The temperature axis in Figure 5.37 is in reverse to give a better representation of the operation time line in which the ELT is high at the beginning of the GSHP operation. Assuming a constant EST, which averages around $14.5^{\circ} \mathrm{C}$, the decrease of the ELT results in a higher temperature difference between the EST and ELT. Figure 5.37 shows the same pattern that the previous cooling test case showed in Figure 5.24. The smaller average difference between the sink and load temperatures in this case resulted in a much higher COP.

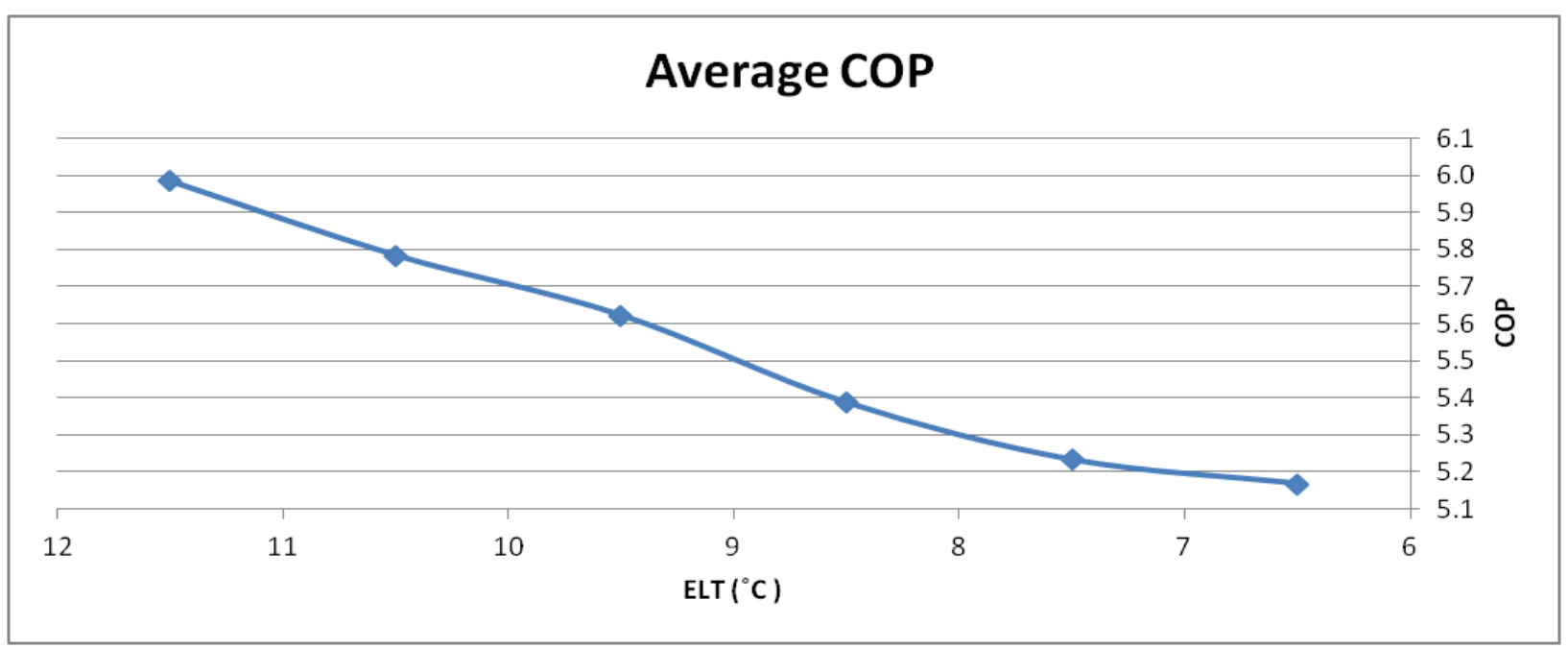

Figure 5.37 : COP vs. load temperature from the buffer tank to GSHP 
Unlike the two previous cases, the combined effect of the ELT and the EST on the COP was not clearly noticed in this test. It is mainly due to the oversized ground loop system when using the vertical and the horizontal loops together compared to the low cooling load of the house. This resulted in a much smaller temperature range that is supplied to the GSHP from the combined loops. Figure 5.38 shows the GSHP average supply and return temperatures from the loops and from the buffer tank for all cycles in the period. The average cycle range is $11 \pm 1$ minutes in which the temperature range entering the GSHP from the loops is $13^{\circ} \mathrm{C}$ to $15.5^{\circ} \mathrm{C}$. Figure 5.39 shows the horizontal and vertical loops average supply and return temperatures for all cycles.

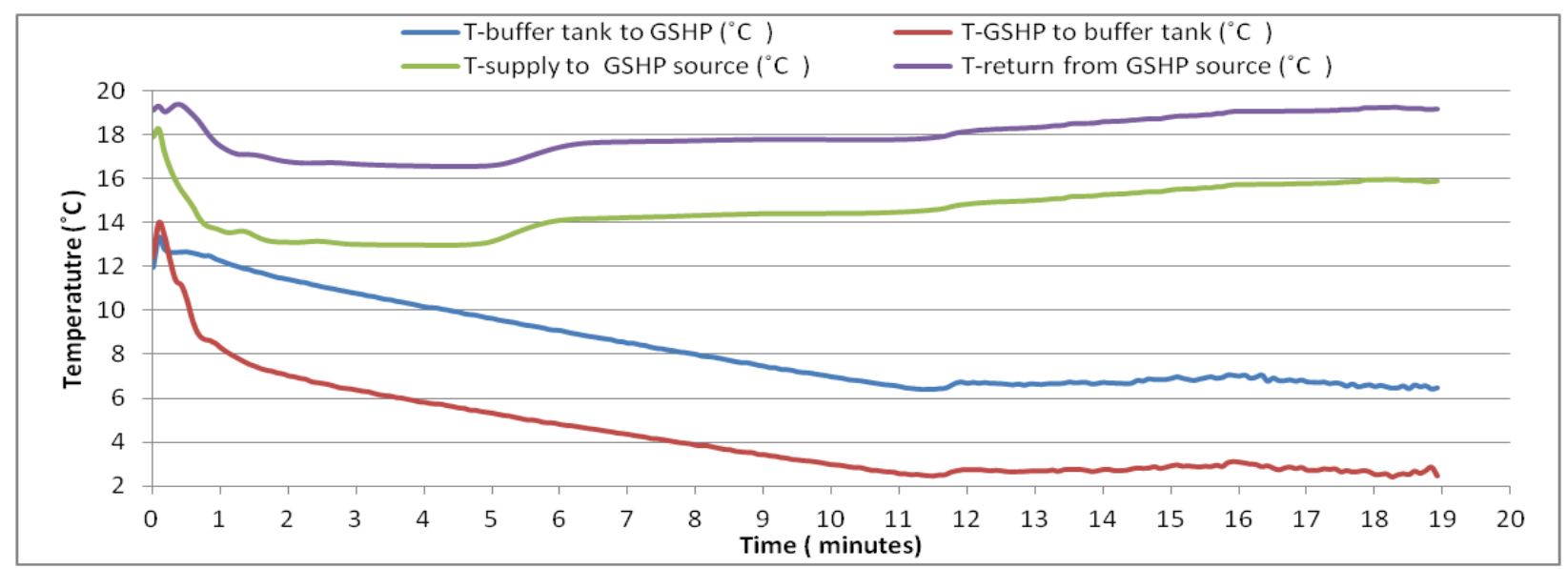

Figure 5.38 : The GSHP average supply and return temperatures from the loops and from the buffer tank

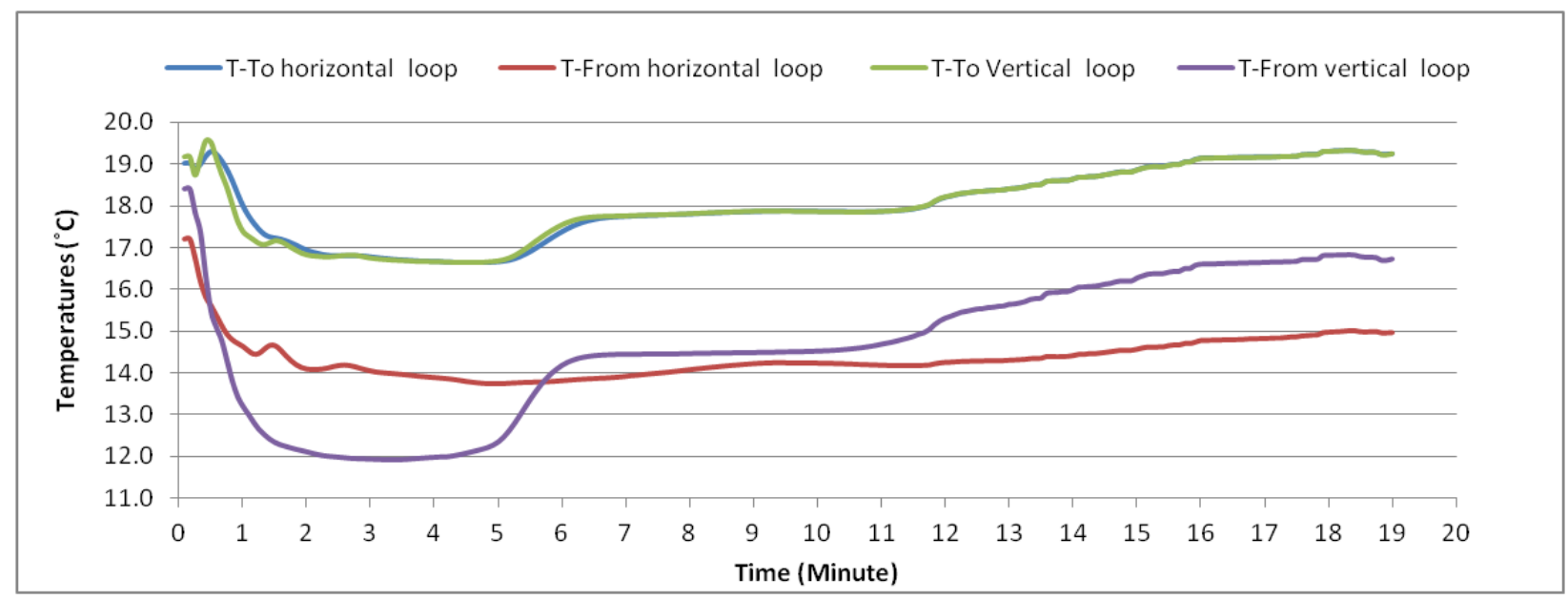

Figure 5.39 : The horizontal and vertical loops average supply and return temperatures for all cycles 
Due to the small cooling load of the buffer tank, the test period average cycle time was 11 minutes. The longest cycle in the test period was recorded at noon of the warmest day in the test period, July 19th. The cycle time was 19 minutes. This was not enough time to reach steady operating conditions of the loops. The thermal mass of the fluid in the vertical and the horizontal loops before starting the GSHP cycles played a more significant part in such short cycles. This resulted in a better performance of the GSHP compared to the first cooling test using the vertical loop alone as seen in Figure 5.40. The Figure shows the average cooling output and the COP of all cycles in the test period versus time.

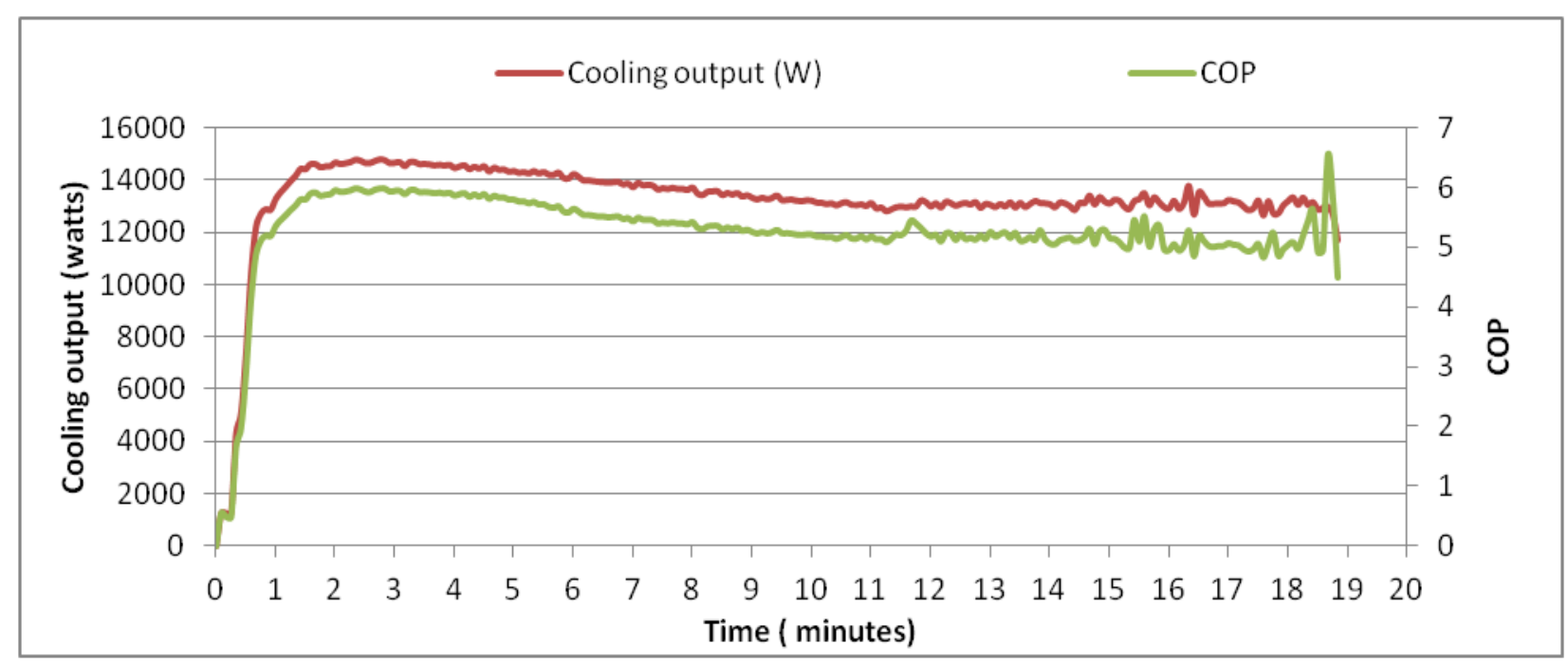

Figure 5.40 : The cooling output and the average COP in the test period

In the first few minutes of each cycle using the vertical loop, the temperature supplied was the temperature of the fluid that was stationary in the loops before the cycle. The fluid needs around 5 minutes to travel from the loop supply to the return with the flow rate used (16 LPM). This period showed a good estimate of the vertical loop temperature profile with depth before the cycles started. Although the beginning of full circulation of the ground loop fluid was noticed after that, the steady conditions were not reached due to the short cycles.

The horizontal loop, on the other hand, supplied a more steady fluid temperature to the GSHP throughout the cycles. The steady fluid temperature is due to the length, diameter and flow rate used in the horizontal loop. The time needed for the fluid to travel from the loop supply 
to the return is around 23 minutes which is more than the longest cycle. The change of the fluid temperature from the horizontal loop is due to the change of the ground level and surface water in the field where it was installed.

\subsubsection{Heat rejection to the ground}

The daily heat rejected to the ground loops from the GSHP is shown in Figure 5.41. From the data collected, the average heat rejected by the GSHP to the vertical and the horizontal loops when operating was $15.47 \mathrm{kWh}$. The average heat rejected by the GSHP to the vertical loop was $7.89 \mathrm{kWh}$ while $7.58 \mathrm{kWh}$ was rejected to the horizontal loop (51\% heat rejected to the vertical loop). Due to equal flow rate, the amount of heat rejected by the GSHP to the vertical and horizontal loops was about the same. However, the vertical loop has much higher heat transfer per unit inside surface area of pipe than the horizontal loop by as much as $203 \%(0.2712$ vs. $0.0895 \mathrm{kWh} / \mathrm{m}^{2}$ ). This is mainly due to higher ground temperature (about $2^{\circ} \mathrm{C}$ higher) at the horizontal loop than at the vertical loop (see Figure 5.39), causing smaller temperature difference between the horizontal loop and its surrounding ground than between the vertical loop and its surrounding ground. Secondary reason is the bigger horizontal pipe than the vertical pipe (1.34" vs. 1.06") which resulted in lower convection heat transfer due to lower Reynolds number of the horizontal loop (4400 vs. 5540).

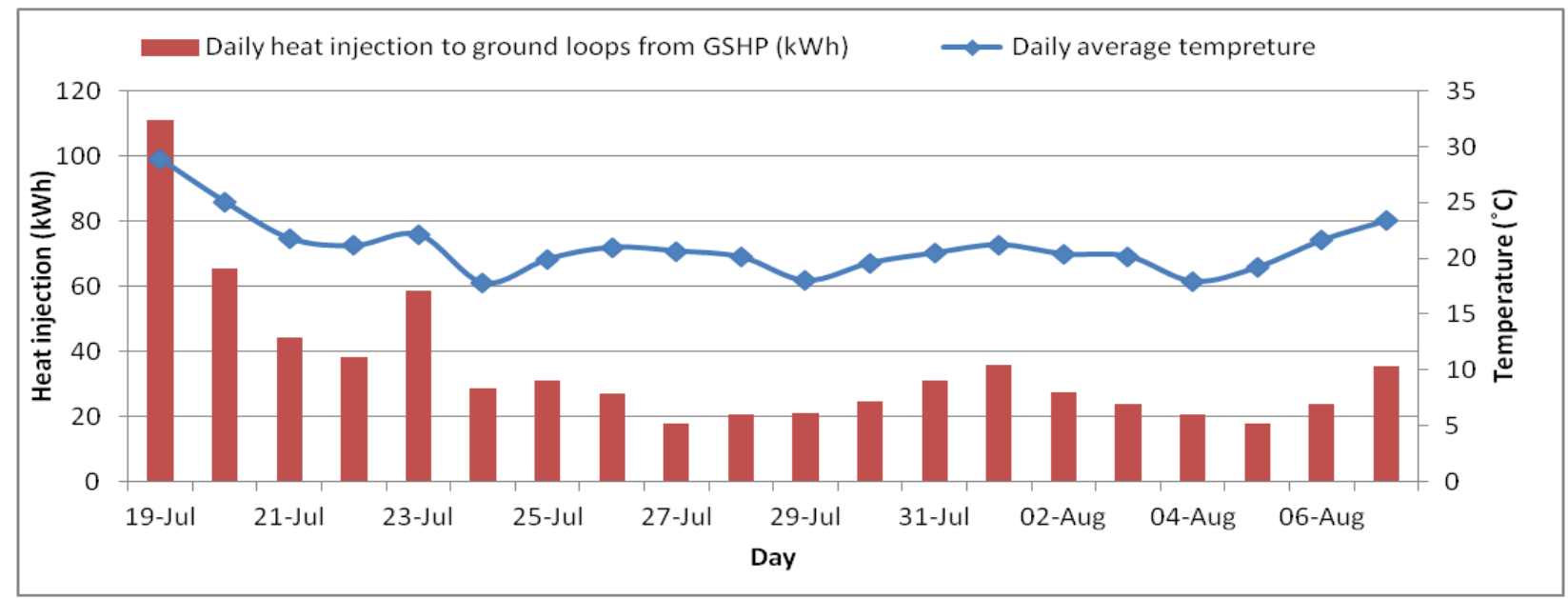

Figure 5.41 : Heat rejection to the ground loops and daily average outdoor temperature 


\subsubsection{Cooling mode using the vertical and the horizontal loops with equal Reynolds number}

(August 9th to September 4th, 2013)

In this part of the test, the vertical and the horizontal loops were connected to the GSHP and the flow was divided between them. The idea in this part is to control the flow in both loops to have the same flow characteristics. Reynolds number was set to an equal value of 4840 in both loops which was achieved by pumping around 28 LPM in the vertical loops and around 35 LPM in the horizontal loops. The choice of using equal Reynolds number in both loops was due to the small adjustments needed in the flow control system and the small pressure drop when controlling the flow in each loop. The data collection started on August 9, 2013. However, as in the last test, missing data and errors in the readings occurred over the weekend of August $17^{\text {th }}$ and $18^{\text {th }}$ due to a power outage in the house. The data from those days were ignored in the analysis and the figures in this section. The data is presented from August $9^{\text {th }}$ to September $4^{\text {th }}$, 2013.

During this part of the test, the maximum and the minimum ambient temperature recorded were $34^{\circ} \mathrm{C}$ and $12^{\circ} \mathrm{C}$, respectively with an average period temperature of $22^{\circ} \mathrm{C}$. As in the last test, the GSHP started when the temperature of the load reached $15^{\circ} \mathrm{C}$ and stopped when the temperature dropped to $5^{\circ} \mathrm{C}$. The flow rate of the water in the GSHP/buffer-tank loop was almost constant at around 47.3 LPM (12.5 US GPM) at all times. In Figure 5.42, the power draw of the different components of the GSHP is shown for one cycle.

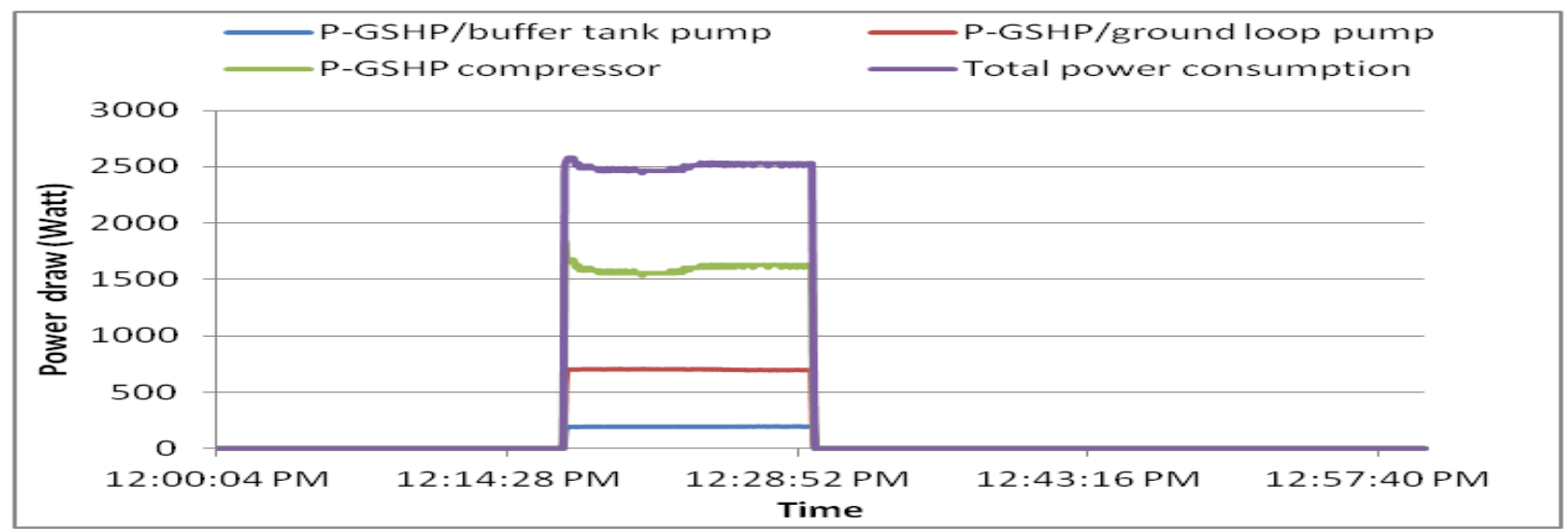

Figure 5.42 : Buffer-tank pump, ground-loop pumps, compressor and total power draw with time 


\subsubsection{Daily operation}

The GSHP operation hours and the daily average outdoor temperature are presented in Figure 5.43. Similar to the last test in 5.4.2, the GSHP compressor accounted for around $65 \%$ of the total power consumption. Figure 5.44 shows the total daily consumption and the daily cooling provided by the GSHP and illustrates a peak daily cooling and electricity consumption of $63 \mathrm{kWh}$ and $11.7 \mathrm{kWh}$ respectively on August 21. The daily peak cooling output and electricity consumption took place on August $21^{\text {st }}$ shortly after the hottest day in the test period. This is due to the thermal mass and the insulation in the house which caused the delay of peak load.

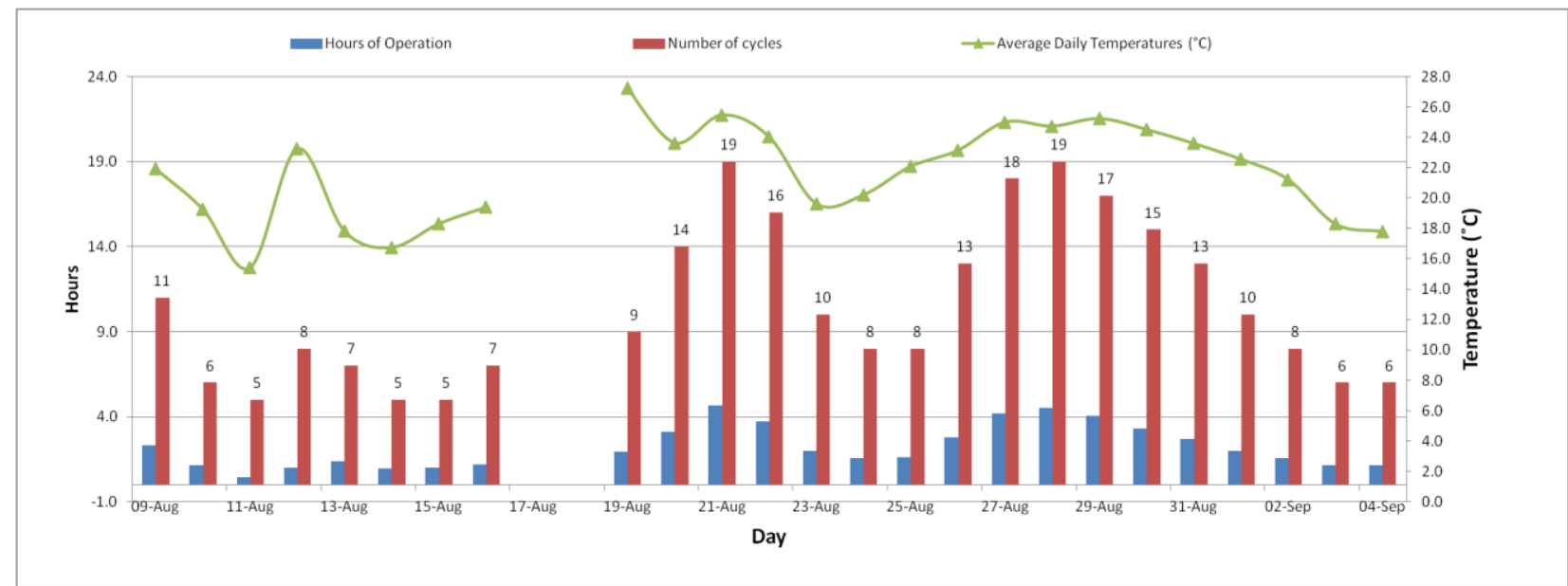

Figure 5.43 : Daily operating hours \& number of cycles of the GSHP system vs. daily average outdoor temperature

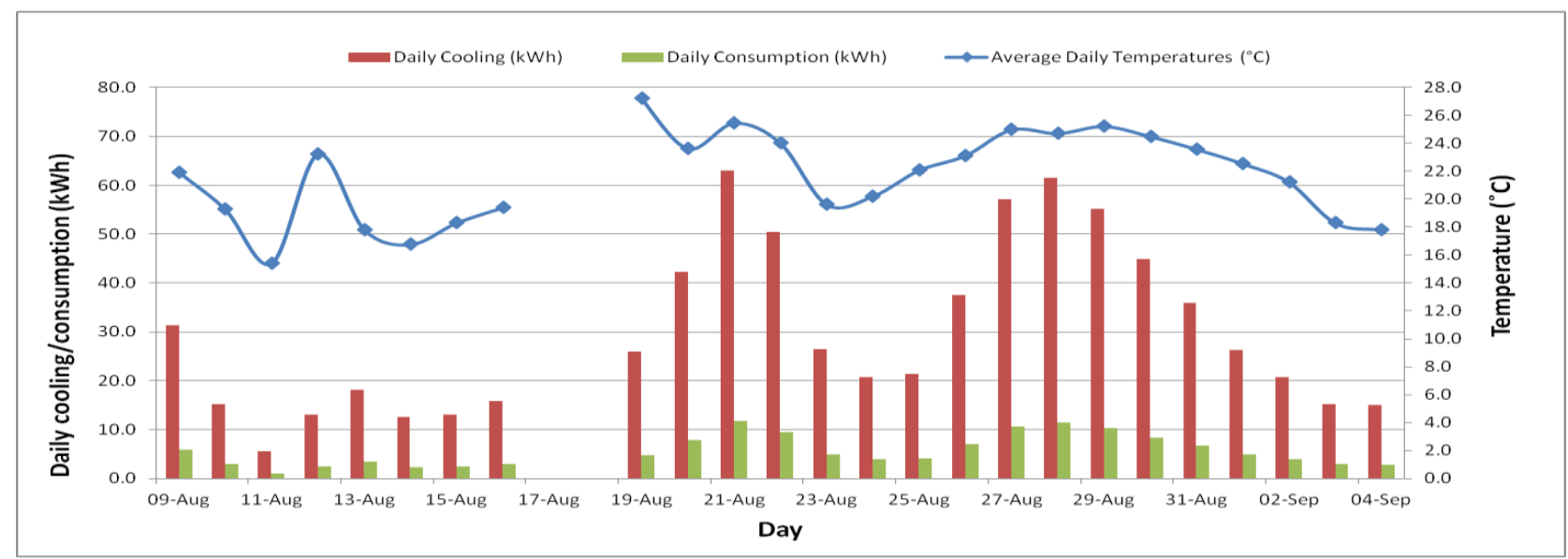

Figure 5.44 : Daily cooling and consumption of the GSHP system vs. daily average outdoor temperature 
Figure 5.45 shows the GSHP daily COP. The daily COP was still higher than the first two cases when the vertical loop was used alone. The daily COP for this period ranged between 5.31 and 5.46 and remained almost constant. During the test period, the average cycle time was around 12 minutes per cycle. Figure 5.46 shows the cumulative cooling output and electricity consumption of the GSHP within this period. The total electricity consumption of the GSHP system during this test period turned out to be $139 \mathrm{kWh}$ and the total cooling output was 745 $\mathrm{kWh}$, which gave a test period COP of 5.36. As in the last case, this high performance of the GSHP was due to the fluid temperature being supplied to the GSHP from the ground loops. The relationship between the daily cooling output and the electricity consumption with respect to the average daily outdoor temperature is shown in Figure 5.47. As the outdoor temperature increases, the cooling load and the power consumption increases.

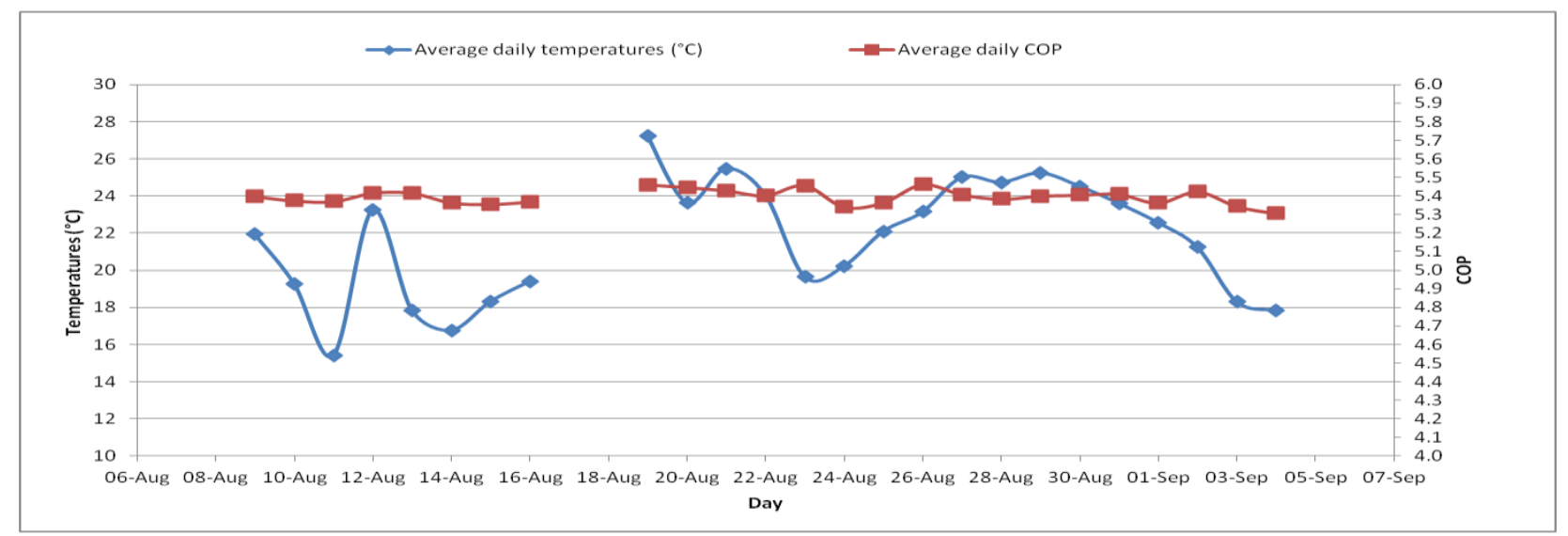

Figure 5.45 : Daily average COP of the GSHP system and daily average outdoor temperature

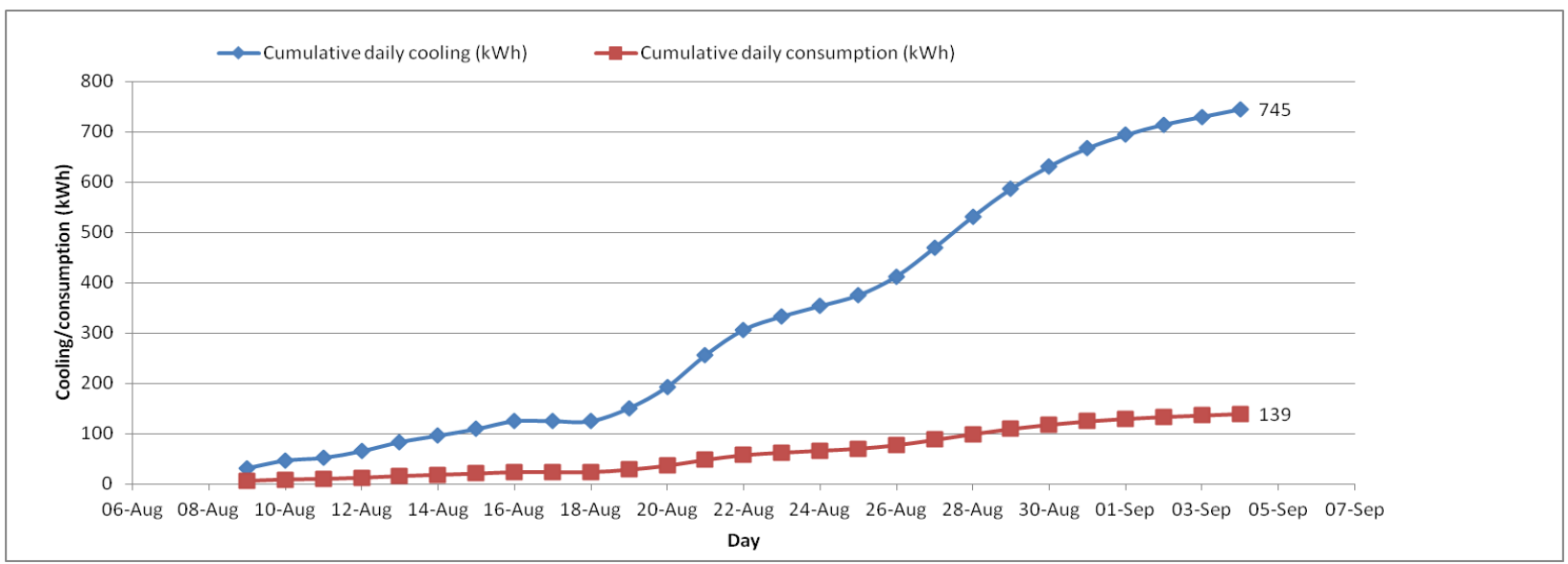

Figure 5.46 : Cumulative cooling and consumption of the GSHP system 


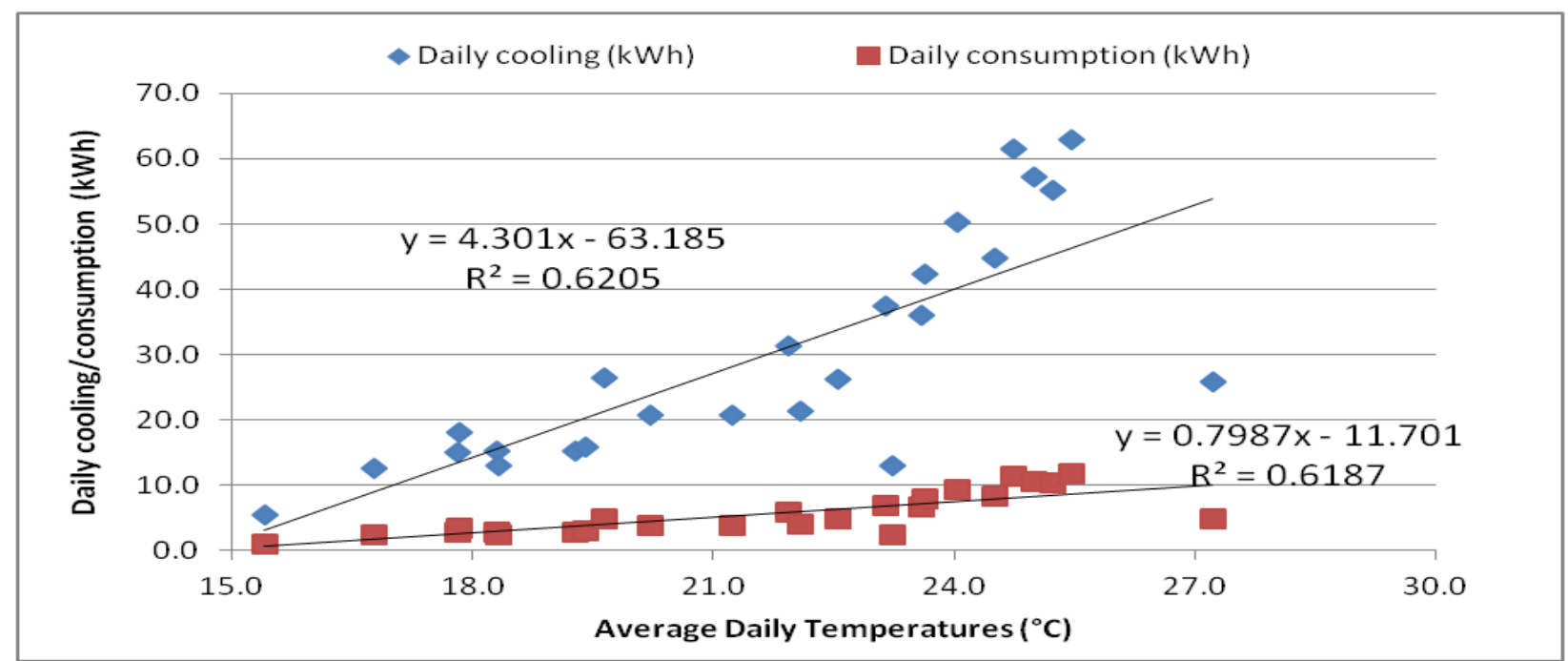

Figure 5.47 : Daily electricity consumption and cooling output vs. average daily outdoor temperature

\subsubsection{Entering Sink Temperature (EST) and Entering Load Temperature (ELT)}

In addition to the last tests, the effect of supplied fluid temperature from the ground loop or the EST is shown in this part. As seen in Figures 5.48-5.50, the power draw by the GSHP system decreases as the EST decreases. In contrast, the cooling output from the GSHP system decreases as the EST increases. Despite fewer data points, due to the smaller range of the EST, the COP relation with the EST is consistent with the other cooling tests. Figure 5.51 is a representation of the rate of change of cooling output, power draw and COP with respect to the change of the EST.

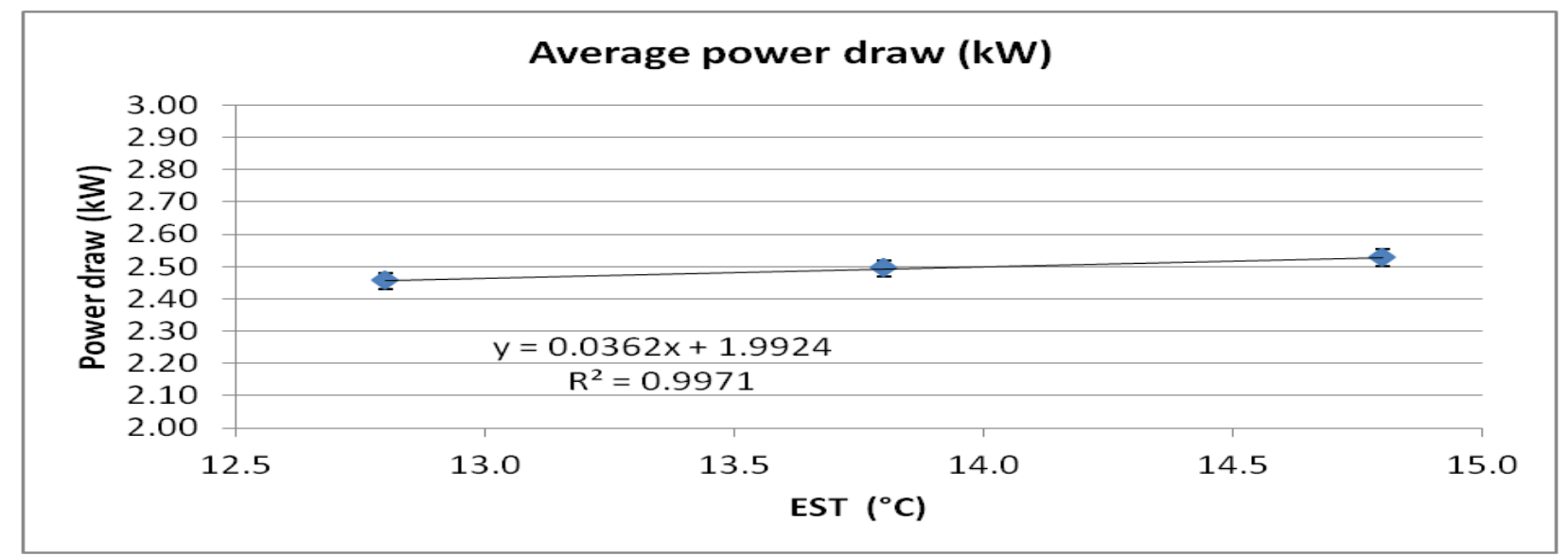

Figure 5.48 : Power draw vs. fluid return temperature from the ground loop 


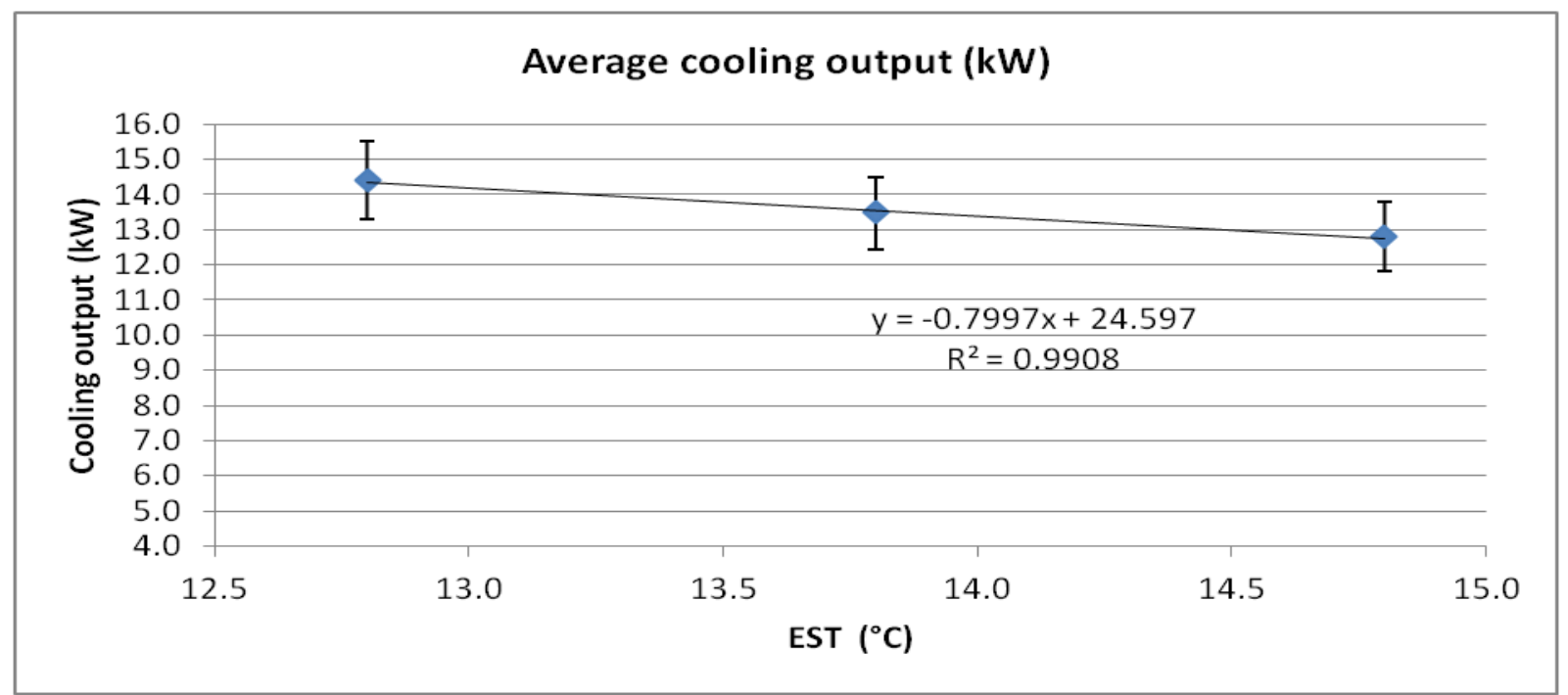

Figure 5.49 : Cooling output vs. fluid return temperature from the ground loop

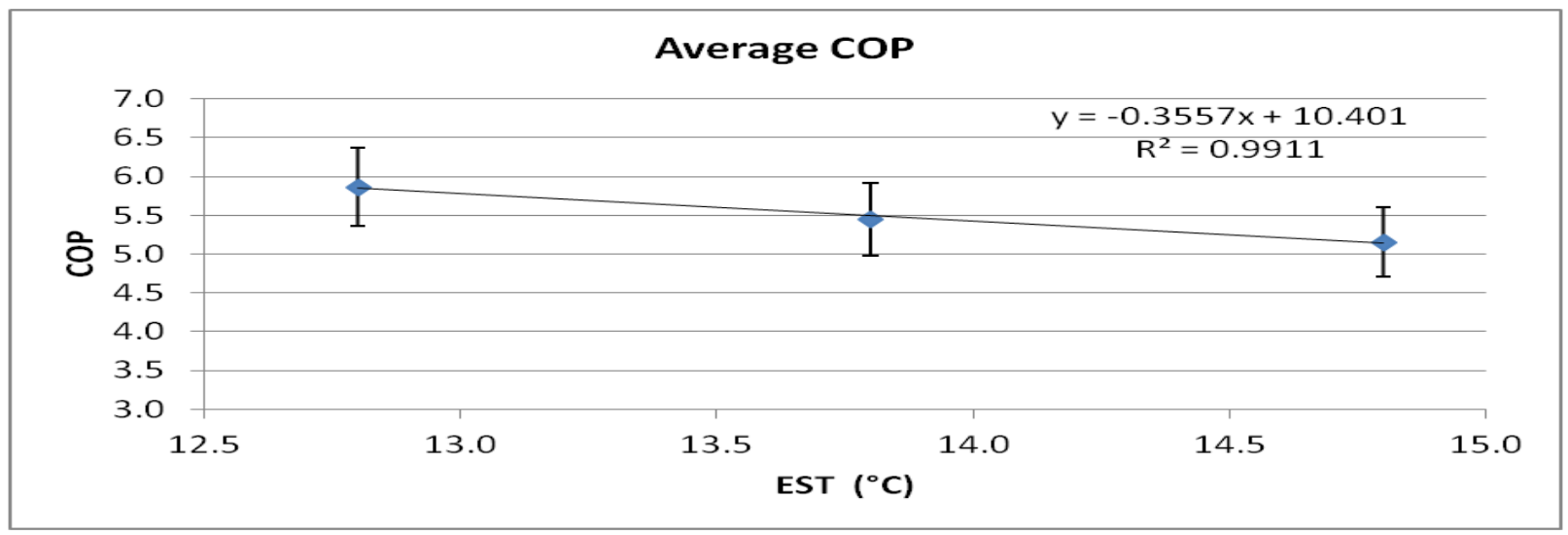

Figure 5.50 : COP vs. fluid return temperature from the ground loop

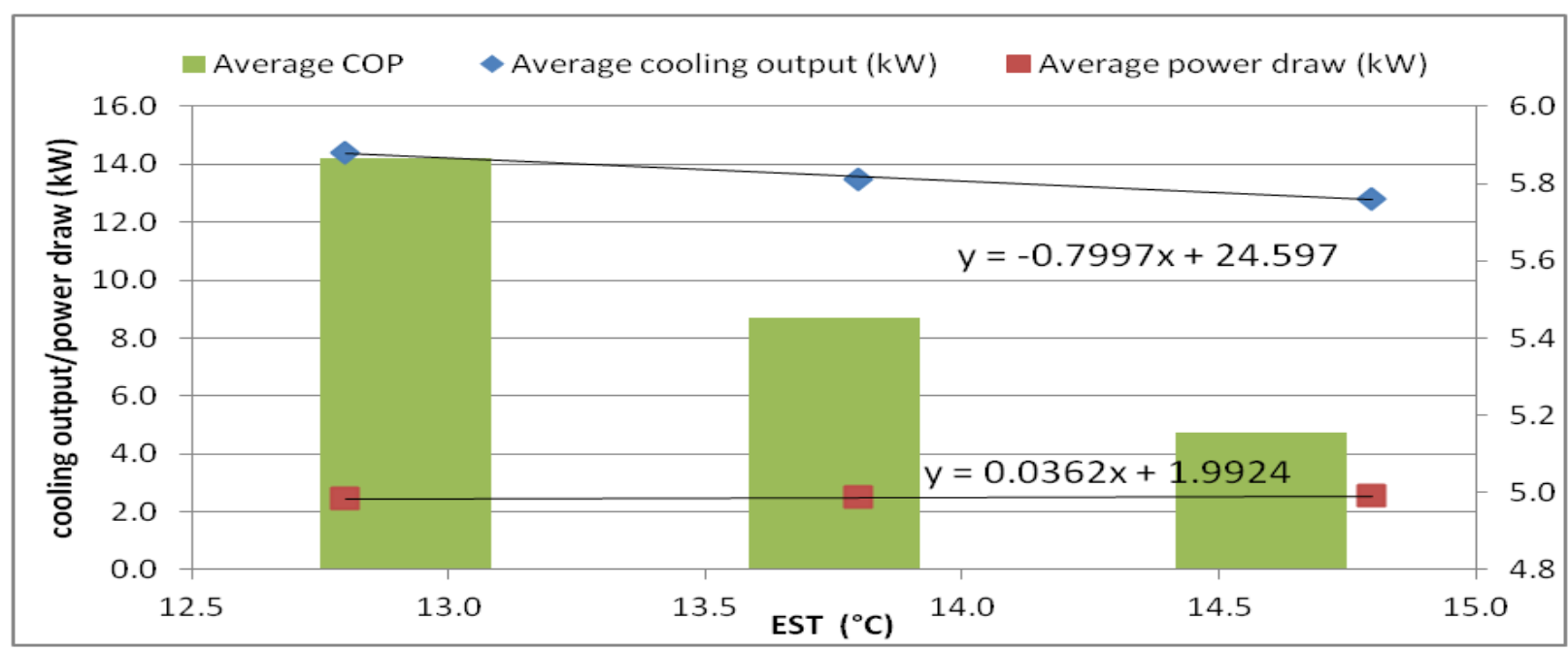

Figure 5.51 : COP, cooling output \& power draw vs. supply temperature from the ground to GSHP 
The change of the performance of the GSHP with different ELT is seen in Figure 5.52. The temperature axis in Figure 5.52 is in reverse to give a better representation of the operation time line where the ELT is high at the beginning of the GSHP operation. Figure 5.52 shows the same behavior that the previous cooling test case showed (Figure 5.37). In the first few points, the change in the COP is smaller than the change when the ELT gets lower due to the temperature difference between the EST and ELT. At the beginning of the operation, when ELT is high, the temperature difference between the ELT and the EST is small as can be seen in the first minute in Figure 5.53.

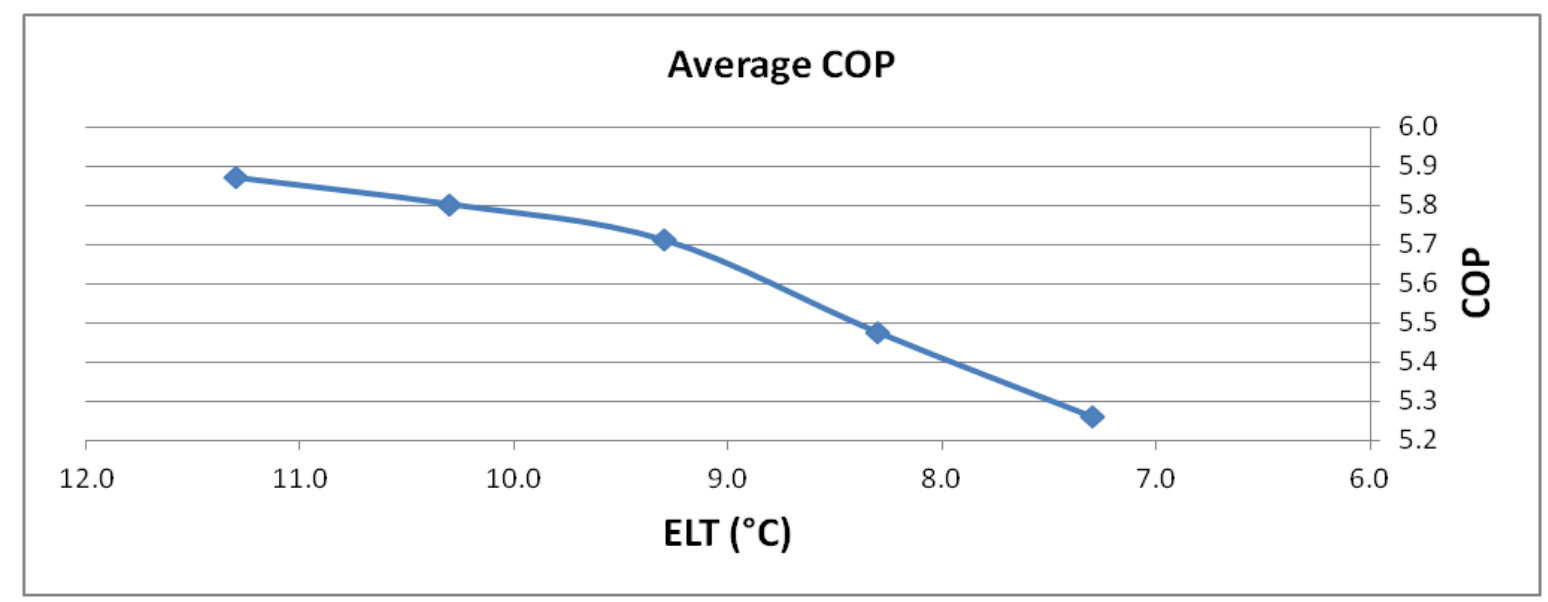

Figure 5.52 : COP vs. Supply temperature from the buffer tank to GSHP

Similar to the last test, the combined effect of the ELT and the EST on the COP is not presented in this section due to the small temperature range that is supplied to the GSHP from the combined loops as seen in Figure 5.53. This figure shows the average of all cycles in the test period. Although the longest cycle in the period is 19 minutes on August 21, the average cycle last for about 12 minutes. In Figure 5.53, the data points after the 12-minute mark represent only a few cycles in the test period which was not enough time to reach steady operating conditions of the loops. In the first five minutes of the cycles, the loops supplied the GSHP with almost a constant fluid temperature at around $13^{\circ} \mathrm{C}$. As in the last case, constant low fluid temperature resulted in higher performance of the GSHP compared to using the vertical loop alone. 
Figure 5.54 shows the average supply and return temperatures for all cycles for the horizontal and vertical loops. Due to the smaller size of the vertical loop, the fluid took around 7 minutes to travel from the supply to the return of the loop with a 14 LPM flow rate which was used to reach the equal Reynolds number. Despite full circulation the 7-minute mark, steady conditions were not reached. The time the horizontal loop fluid needed to travel from the loop supply to the return was around 21 minutes which is more than the longest cycle recorded. Throughout all of the cycles in this period, the horizontal loop acted almost like a constant fluid temperature bank which helped in increasing the performance of the GSHP. Figure 5.55 shows the average cooling output and the COP of all cycles in the test period versus time. In the first few minutes, the COP is at the highest range when both the vertical and the horizontal loops supplied the GSHP with a relatively constant fluid temperature. After that, the vertical loop circulation is noticed resulting in warmer fluid entering the GSHP, which lowers the GSHP COP.

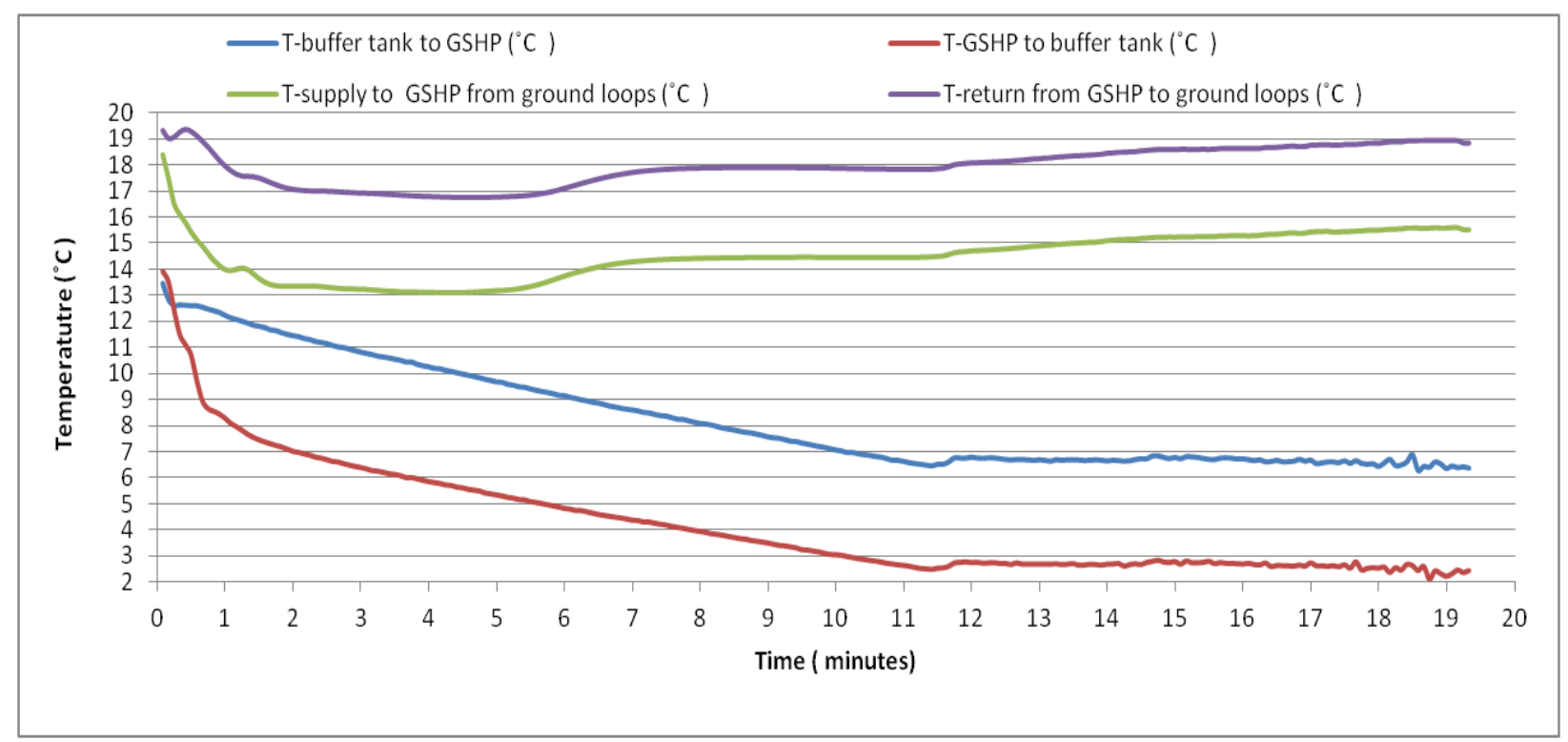

Figure 5.53 : The GSHP average supply and return temperatures from the loops and from the buffer tank for all cycles 


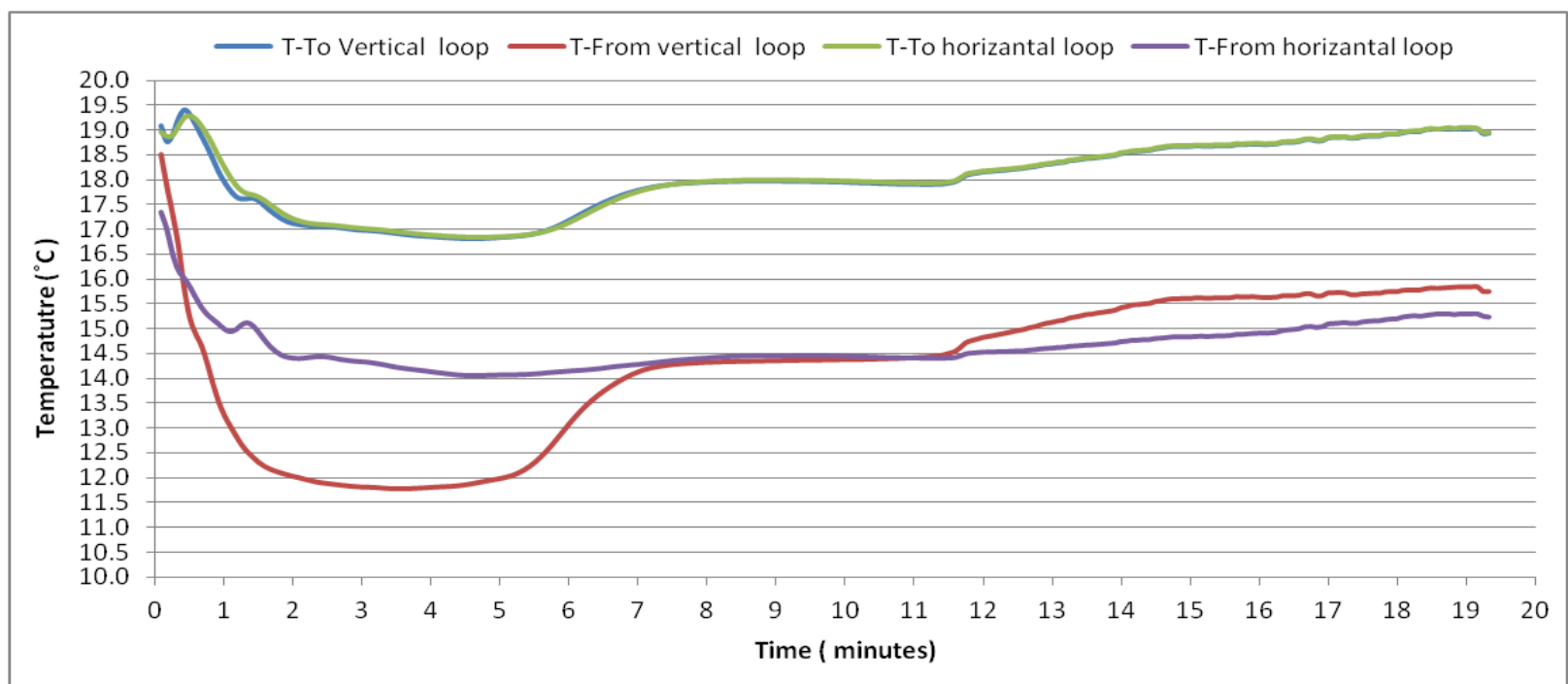

Figure 5.54 : The horizontal and vertical loops average supply and return temperatures for all cycles

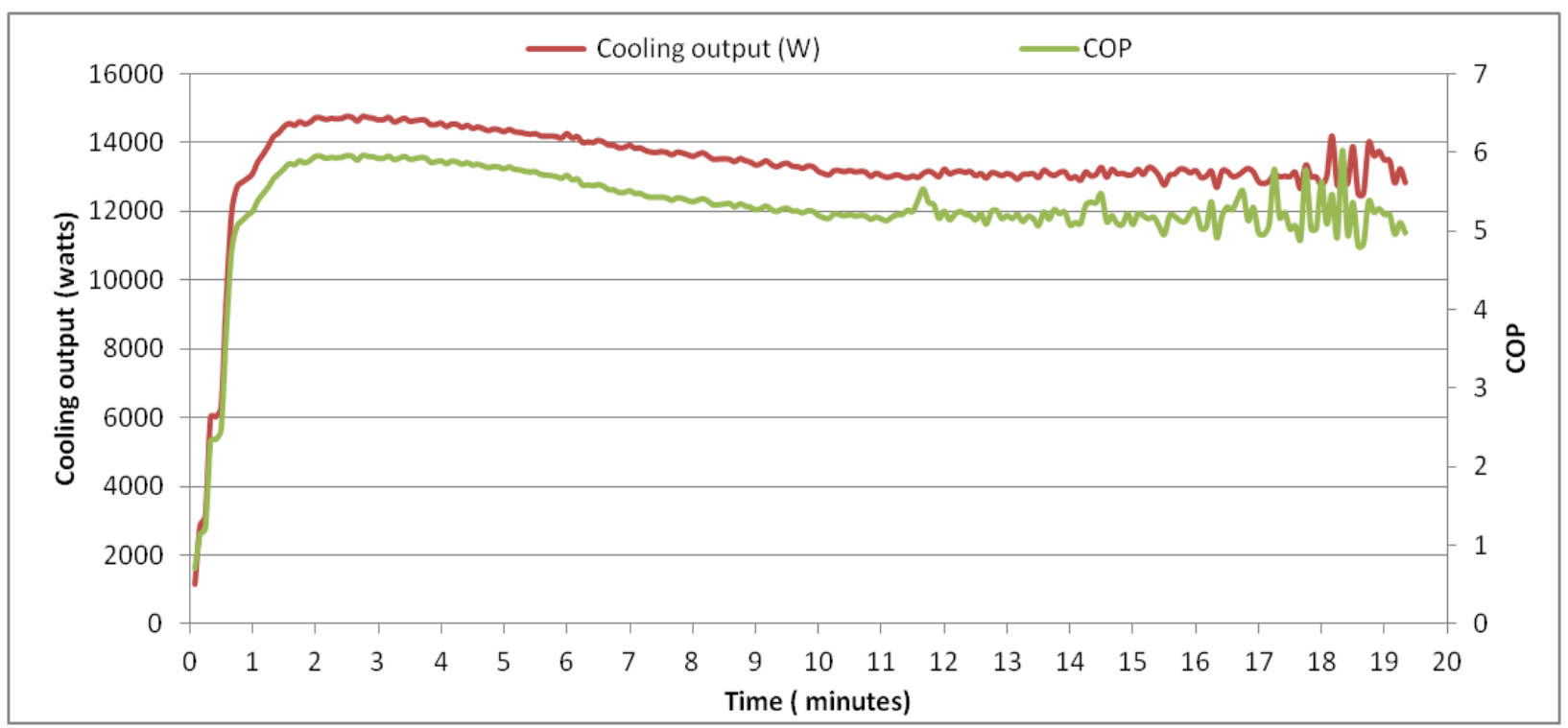

Figure 5.55 : The cooling output and the COP average of all cycles in the test period

\subsubsection{Heat rejection to the ground}

The daily heat rejected to the ground loops from the GSHP is shown in Figure 5.56. From the data collected, the average heat rejected by the GSHP to the ground loops when operating was $15.77 \mathrm{kWh}$. The average heat rejected by the GSHP to the vertical loop was $8.21 \mathrm{kWh}$ while $7.56 \mathrm{kWh}$ was rejected to the horizontal loop (52\% heat rejected to the vertical loop). Again, the 
vertical loop has much higher heat transfer per unit inside surface area of pipe than the horizontal loop by as much as $216 \%\left(0.2823\right.$ vs. $0.0893 \mathrm{kWh} / \mathrm{m}^{2}$ ). In terms of unit length of pipe, the convection heat transfer is the same between the horizontal and vertical loops, due to similar hydrodynamic condition. In theory, the horizontal loop should have an overall higher heat transfer than the vertical loop, because of its longer length, but it was not the case for this test. This is due to higher ground temperature (about $2.4^{\circ} \mathrm{C}$ higher) at the horizontal loop than at the vertical loop (see Figure 5.54), causing smaller temperature difference between the horizontal loop and its surrounding ground than between the vertical loop and its surrounding ground. This shows that a change in ground temperature surrounding the ground loop can have big effect on the heat transfer performance of the ground loop.

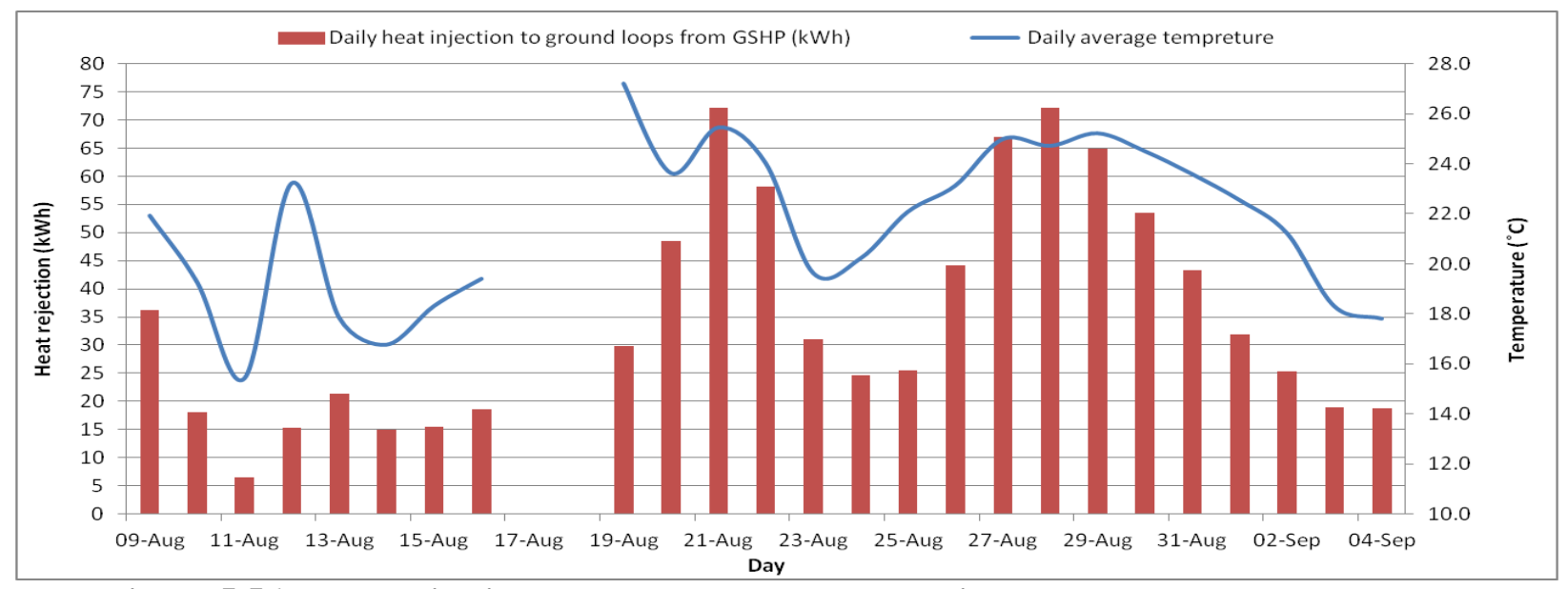

Figure 5.56 : Heat rejection to the ground loops and daily average outdoor temperature

\subsection{Vertical and horizontal loops tests summary}

In the last two tests, the horizontal and the vertical loops have been used as a heat sink for the GSHP. In the first test, equal flow was used in both loops, whereas the second test used equal Reynolds numbers by using a higher flow rate in the horizontal loop. The GSHP performance was much higher than the GSHP specifications in both tests as the loops supplied a low and constant fluid temperature to the GSHP for most of the operation time. Regardless of the fluid temperature that has been pumped to the ground loops, the return temperature from the loops was 
not greatly affected. The oversized loops and the small house cooling load resulted in short cycling time. Table 5.3 shows the summary of the vertical and the horizontal loops tests period.

Table 5.3 : Summary of vertical and the horizontal loops test periods

\begin{tabular}{|c|c|c|c|c|c|}
\hline Cooling test period & Ground loop & $\begin{array}{c}\text { Heat rejected } \\
\text { to loops }(\mathrm{kWh})\end{array}$ & $\begin{array}{l}\text { GSHP cooling } \\
\text { output }(\mathbf{k W h})\end{array}$ & $\begin{array}{c}\text { GSHP electricity } \\
\text { consumption }(k W h)\end{array}$ & COP \\
\hline $\begin{array}{l}\text { Equal flow } \\
\text { Jul } 19 \text { - Aug 7, } \\
2013\end{array}$ & $\begin{array}{l}\text { Vertical loop: } \\
\text { Reynolds number } \mathbf{5 5 4 0} \\
\text { Flow rate: } 32 \text { (LPM) } \\
\text { Horizontal loop: } \\
\text { Reynolds number } \mathbf{4 4 0 0} \\
\text { Flow rate: } 32 \text { (LPM) }\end{array}$ & $\begin{array}{l}\text { Total: } 15.47 \\
\text { Vertical: } 7.89 \\
\text { Horizontal: } 7.58\end{array}$ & 607 & 112 & 5.42 \\
\hline $\begin{array}{l}\text { Equal Reynolds } \\
\text { number } \\
\text { Aug } 9 \text {-Sep 4, } 2013\end{array}$ & $\begin{array}{l}\text { Vertical loop: } \\
\text { Reynolds number } \mathbf{4 8 4 0} \\
\text { Flow rate: } \mathbf{2 8} \text { (LPM) } \\
\text { Horizontal loop: } \\
\text { Reynolds number } \mathbf{4 8 4 0} \\
\text { Flow rate: } \mathbf{3 5} \text { (LPM) }\end{array}$ & $\begin{array}{l}\text { Total: } 15.77 \\
\text { Vertical: } 8.21 \\
\text { Horizontal: } 7.56\end{array}$ & 745 & 139 & 5.36 \\
\hline
\end{tabular}

In both tests, the vertical loop supplied a lower fluid temperature. Looking to the temperature that has been supplied to the GSHP before the circulation was noticed, the fluid from the vertical loop had a lower temperature at around $12^{\circ} \mathrm{C}$. Although the temperature was stable during the test periods, the horizontal loop fluid supply to the GSHP was at $14^{\circ} \mathrm{C}$. The horizontal loop was affected by the high ambient temperature due to the shallow depth.

Looking to the COPs in both tests, the first test with equal flow had a slightly better COP than the second test where equal Reynolds numbers were used. The second test used more flow in the slightly warmer horizontal loop resulting in a lower COP compared to the first test. The COP in the first case was in the range between 5.36 and 5.48 whereas the second test COP ranged between 5.31 and 5.46 . 


\section{-Data Analysis Summary and Results}

The GSHP system used the vertical loop in the first two tests in this study. Using the vertical loop, the GSHP performed very well in the heating test period with a COP range of 2.7 (at an ELT of $45^{\circ} \mathrm{C}$ and EST of $0.5^{\circ} \mathrm{C}$ ) to 3.15 (at an ELT of $40.5^{\circ} \mathrm{C}$ and EST of $3.5^{\circ} \mathrm{C}$ ). The second test used the vertical loop but in the cooling mode. In the cooling mode test, the GSHP performed much better than the heating mode with a COP range of 3.75 (at an ELT of $3^{\circ} \mathrm{C}$ and an EST of $19.5^{\circ} \mathrm{C}$ ) to 5.4 (at an ELT of $10.5^{\circ} \mathrm{C}$ and an EST of $16.5^{\circ} \mathrm{C}$ ). During both tests, the GSHP showed a relatively constant performance, which can be explained by a relatively constant ground temperature. In both tests, the GSHP power draw was greatly affected by the temperature difference between the ELT and the EST.

Table 5.4 shows a summary of the cooling and heating seasonal performance of the GSHP when using the vertical loop in this test and the results that were obtained in 2009 by $\mathrm{Mr}$. Amir Safa with the same system, but with the horizontal ground loop (Safa, 2012). Both tests had the same load and source flow rates. The only major difference was that the horizontal ground loop had a $30 \%$ propylene glycol concentration and the vertical loop had $20 \%$ propylene glycol concentration. The overall COP is the COP presented in chapter 4 and used in this study. However, the GSHP COP was obtained considering the GSHP compressor and the ground loop circulating pumps consumption. Although the horizontal ground loop is more than twice the length and has 3.8 the fluid volume of the vertical loop, the GSHP had much better performance using the vertical loop. The horizontal loop is affected by the weather conditions due to its shallow depth. However, the vertical loop showed a constant performance throughout the test periods, which can be explained by a relatively constant ground temperature at the deeper depths.

Table 5.4 : Comparison of the cooling and heating seasonal performance of the GSHP with different ground loops

\begin{tabular}{|l|c|c|c|c|}
\hline \multirow{2}{*}{ Test } & \multicolumn{2}{|l|}{ GSHP using the vertical loop. } & \multicolumn{2}{l|}{ GSHP using the horizontal loop (Safa, 2012). } \\
\cline { 2 - 5 } & Heating season & Cooling season & Heating season & Cooling season \\
\hline Overall COP & 2.95 & 4.5 & - & - \\
\hline GSHP COP & 3.10 & 4.73 & 2.86 & 3.98 \\
\hline
\end{tabular}


The last two tests of this study, the GSHP used both ground loops in parallel. Although the intended steady operating conditions of both loops were not achieved due to the small house cooling load, the short cycle performance was noted. The first test used equal flow rates in each loop, whereas the last test used more flow in the horizontal loop to reach the same Reynolds number as the vertical loop. A summary of the performance of the GSHP is shown in Table 5.5. The first cooling test using equal flow had a slightly better COP than the last test. When more flow was directed to the horizontal loop to reach an equal Reynolds number, the GSHP received more flow from the warmer horizontal loop which resulted in lower COP.

Table 5.5 : Comparison of cooling seasonal performance of the GSHP using both ground loops

\begin{tabular}{|l|c|c|c|c|}
\hline \multirow{2}{*}{ Test } & \multicolumn{2}{|c|}{ Cooling (Jul 19- Aug 7, 2013) } & Cooling (Aug 9 - Sep 4, 2013) \\
\cline { 2 - 5 } & Horizontal Loop & Vertical Loop & Horizontal Loop & Vertical Loop \\
\hline Flow rate (LPM) & 32 & 32 & 36 & 28 \\
\hline $\begin{array}{l}\text { Lowest fluid supply temperature } \\
\text { recorded from the loops }\left({ }^{\circ} \mathrm{C}\right)\end{array}$ & 13.7 & 11.9 & 14.1 & 11.7 \\
\hline Overall COP & \multicolumn{2}{|c|}{5.42} & & \multicolumn{2}{c|}{5.36} \\
\hline
\end{tabular}




\section{CHAPTER 6 SUMMARY \& CONCLUSIONS}

\section{Author's Contribution}

This thesis is focused on the performance analysis of a vertical and a horizontal coupled ground source heat pump system. The Archetype Sustainable House project presented the opportunity to study and compare one of the most efficient residential heating and cooling devices: a ground source heat pump system. In this regard, the author has performed the following activities:

- Design and execution of the ground loops flow control system.

- Replacement of the ground loop fluid with the optimum concentration of water/PG solution for the loops.

- Installation of all the sensors.

- Calibration of all the sensors.

- Implementation of the Data Acquisition (DAQ) system.

- Validating the collected data from all related sensors, through cross-checking and performing calibration, when required.

- Thermal performance analysis of the components of the GSHP system, and comparing the results with the manufacturer's data.

- Further analysis was done during the experiment to investigate the issues with the as-built system when discovered.

- Regular monitoring and backup of the database to insure the quality of the data collected during the test.

- Determination of the errors of all measured and derived data through uncertainty analysis 


\subsection{Conclusions}

The present study on the performance of a vertical and a horizontal ground loops coupled to a ground source heat pump system was conducted at the Archetype Sustainable twin houses located in Vaughan, Canada. These results demonstrate that GSHP is viable and energy efficient alternative to conventional systems for heating and cooling applications. From the results of the experimental study, the following conclusions were obtained:-

- The experiment was designed and constructed and operate successfully without any serious defects during the test periods.

- The performance of the GSHP was not affected by the weather conditions during the tests.

- The cooling performance of the GSHP was higher than the heating performance due to the lower temperature deference between the ground loop supplied temperature to the GSHP and the load supplied temperature to the GSHP. In the vertical ground loop tests for example, the test periods' COP of the GSHP system were 2.95 in the heating mode and 4.5 in the cooling mode.

- When using both ground loops, the cooling COP of the GSHP system was 5.42 when both loops had equal flow and 5.36 when both loops had equal Reynolds number.

- The GSHP compressor accounted for the majority of the GSHP's total power consumption and is effected by both the EST and the ELT.

- The effects of the EST and the ELT on the COP of the GSHP were shown in the experimental results.

- The GSHP showed high COP at the beginning of operation cycles.

- Operation cycles time affected the COP of the GSHP. 
- Experimental results showed that the GSHP have a higher COP when using the vertical ground loop compared to the horizontal loop.

- The study showed that a vertical U-tube GHE configuration is preferred because it requires less ground area and offers better performance due to smaller seasonal swing in the ground mean temperature compared horizontal loop configuration. The fluid supply temperature from the vertical ground loop was not affected by the weather conditions during the tests. However, solar radiation near the ground surface, and warm weather conditions in the summer affected the horizontal ground loop. The fluid supply temperature from the horizontal loop increased at the end of the cooling season by almost $2^{\circ} \mathrm{C}$.

- The GSHP showed higher frequency and shorter operating times than expected. This is an indication of an oversized GSHP when the required load is a fraction of the GSHP capacity which often causes lower reliability of equipment.

- There are challenges associated with the evaluation of ground loop heat exchangers due to the fact that they present a unique type of heat transfer problem. First, heat transfer within the ground can be highly transient. Also, it is difficult to make reliable measurements and conclusive interpretations of the underground environment.

- The vertical loop has much higher heat transfer per unit area of pipe than the horizontal loop due to higher ground temperature at the horizontal loop than at the vertical loop, causing smaller temperature difference between the horizontal loop and its surrounding ground than between the vertical loop and its surrounding ground.

Despite the issues and the drawbacks, this experimental study has contributed a fair amount of insights that is considered new in the literature. The GSHP system at the Archetype Sustainable houses has allowed for a direct and side-by-side comparison of loops performance in a real residential setting. The advanced monitoring system was capable of generating a clean and accurate data. 


\subsection{Recommendations}

The following recommendations are made based on the results of this study:

- It is highly recommended that a seasonal optimization of the buffer tank set-point temperature is carried out. The current set-point temperature is only based on the multizone AHU and in-floor radiant heating. The optimized set-point temperature is needed to account for the GSHP performance and the compressor consumption with the supplied load.

- Conduct an in-situ thermal conductivity test by injecting a constant source of heat into the horizontal and the vertical loops to study the long term performance of the loops.

- Installation of temperature sensors along the length of the horizontal loop to monitor the temperature profile.

- A more powerful Data Acquisition Systems with more computational power and storage capabilities should be installed for future work to reduce the risk of data loses and errors. the

- It is recommended that a variable speed circulation pump be used to study the effects of different flow characterises and heat transfer in ground loops.

\subsection{Future Work}

- Locate the horizontal loops exact location and install new flow control valves that would allow the use of half the loop length to allow for more operational options.

- Long term monitoring of the loops using a constant heat input to determine the loops temperature profile.

- Test, analyze and optimize the GSHP along with the AHU and the in-floor system.

- A long term comparison of horizontal vs. vertical ground loop configuration in both heating and cooling seasons. 


\section{APPENDIX}

\section{Appendix A}

\section{A.1: Water Properties (GSHP/buffer tank loop)}

A graph was created as shown in Figure A.1 to illustrate the relationship between the density of water and temperature. Also, the relation between the density, the specific heat and temperature are shown in Table A.1. These relationship are used to calculate the heating and cooling of water systems for the GSHP.

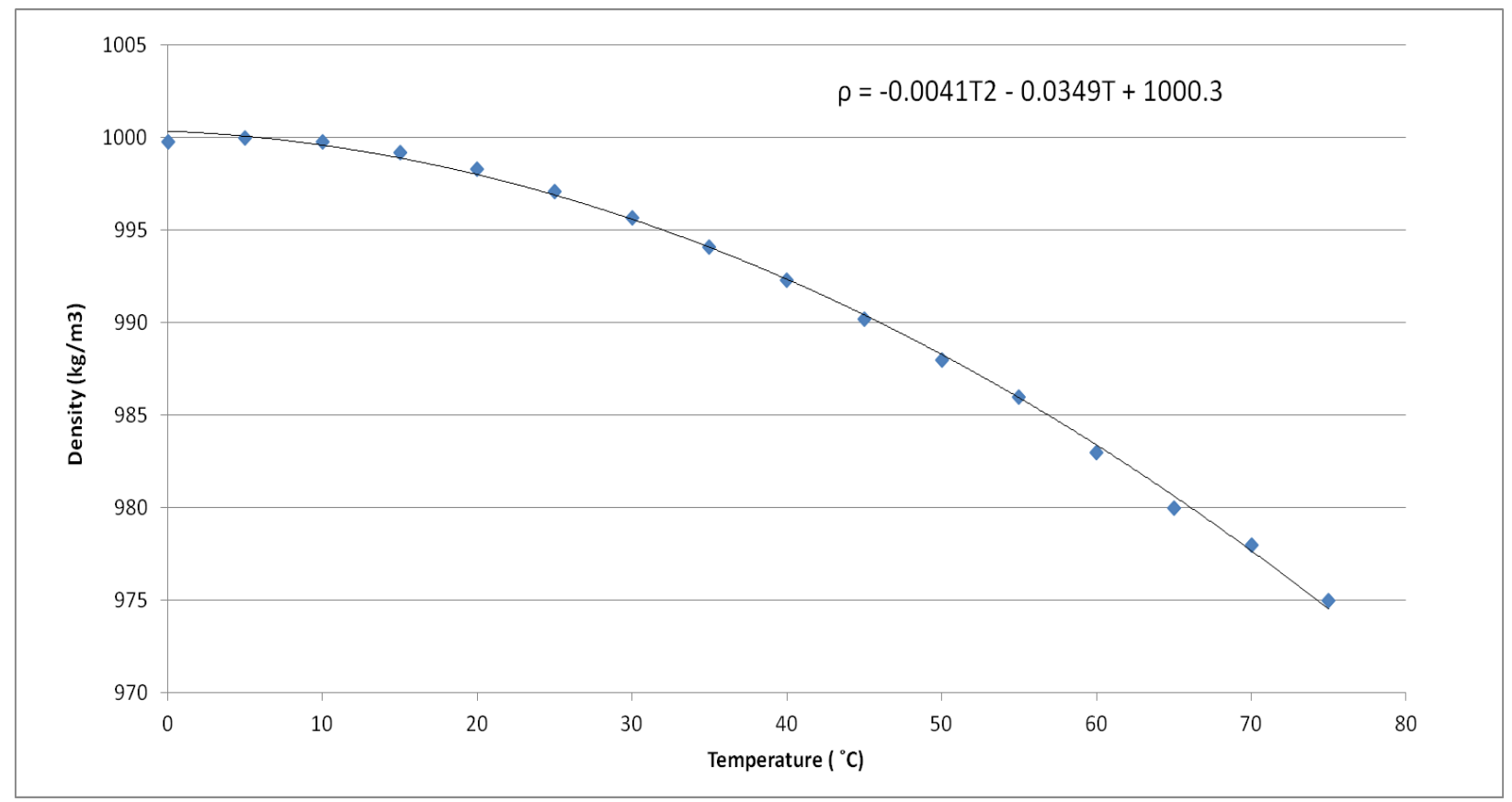

Figure A.1 : Density of water(ASHRAE Handbook, 2009). 
Table A.1 : Density and specific heat of water (ASHRAE Handbook, 2009)

\begin{tabular}{|c|c|c|}
\hline $\begin{array}{c}\text { Temperature } \\
\left({ }^{\circ} \mathbf{C}\right)\end{array}$ & $\begin{array}{l}\text { Density } \\
\left(\mathrm{kg} / \mathrm{m}^{3}\right)\end{array}$ & $\begin{array}{c}\text { Specific Heat } \\
(\mathrm{kJ} / \mathrm{kg} \cdot \mathrm{K})\end{array}$ \\
\hline 0.01 & 999.8 & 4.21 \\
\hline 5 & 1000 & 4.204 \\
\hline 10 & 999.8 & 4.193 \\
\hline 15 & 999.2 & 4.186 \\
\hline 20 & 998.3 & 4.183 \\
\hline 25 & 997.1 & 4.181 \\
\hline 30 & 995.7 & 4.179 \\
\hline 35 & 994.1 & 4.178 \\
\hline 40 & 992.3 & 4.179 \\
\hline 45 & 990.2 & 4.181 \\
\hline 50 & 988 & 4.182 \\
\hline 55 & 986 & 4.183 \\
\hline 60 & 983 & 4.185 \\
\hline 65 & 980 & 4.188 \\
\hline 70 & 978 & 4.191 \\
\hline 75 & 975 & 4.194 \\
\hline
\end{tabular}

\section{A.2: PG/Water Mixture (Ground Loops)}

The ground loops use a mixture of water and antifreeze called Propylene Glycol (PG). The volume ratio is $20 \%$ Propylene Glycol \& $80 \%$ water. A graph was created as shown in Figure A.2 to illustrate the relationship between the density of the mixture and temperature. Also, the relation between the density, the specific heat and temperature are shown in Table A.2. These relationship are used to calculate the heat extraction/rejection from/to ground loops. 


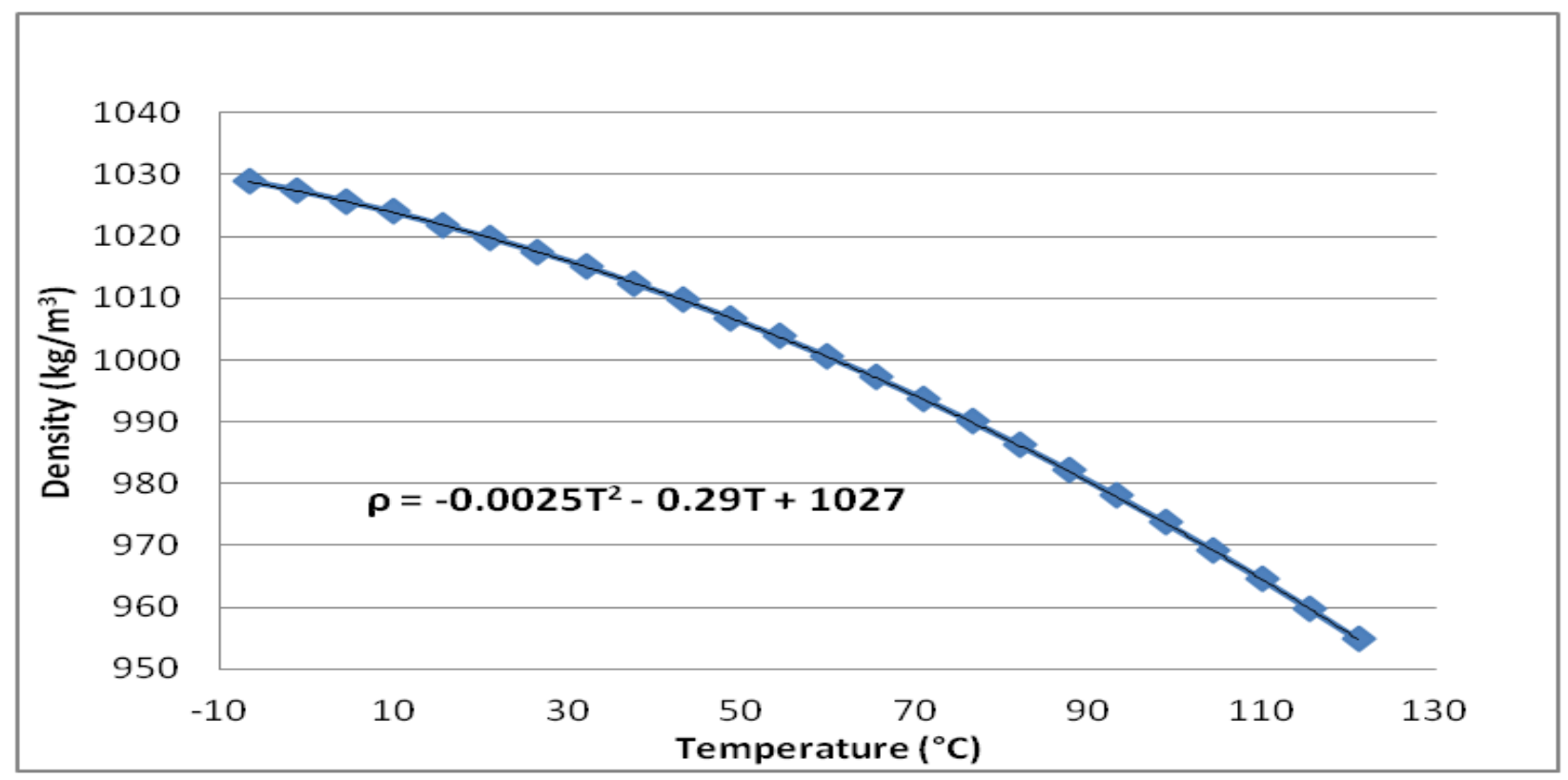

Figure A.2 : Density of 20\% PG and 80\% water (ASHRAE Handbook, 2009)

Table A.2 : Density and specific heat of 20\% PG and $80 \%$ water (ASHRAE Handbook, 2009)

\begin{tabular}{|c|c|c|c|}
\hline $\begin{array}{c}\text { Temperature } \\
\left({ }^{\circ} \mathbf{C}\right)\end{array}$ & $\begin{array}{c}\text { Density } \\
\left(\mathbf{k g} / \mathbf{m}^{\mathbf{3}}\right)\end{array}$ & $\begin{array}{c}\text { Specific } \\
\text { Heat } \\
(\mathbf{k J} / \mathbf{k g} \cdot \mathbf{K})\end{array}$ & $\begin{array}{c}\text { Viscosity } \\
(\mathbf{k g} / \mathbf{m} \cdot \mathbf{s})\end{array}$ \\
\hline-6.7 & 1028.9 & 3.92 & 0.0054 \\
\hline-1.1 & 1027.4 & 3.93 & 0.0042 \\
\hline 4.4 & 1025.7 & 3.94 & 0.0034 \\
\hline 10 & 1023.9 & 3.95 & 0.0028 \\
\hline 15.6 & 1021.8 & 3.97 & 0.0023 \\
\hline 21.1 & 1019.7 & 3.98 & 0.0020 \\
\hline 26.7 & 1017.5 & 3.99 & 0.0017 \\
\hline 32.2 & 1015.1 & 4.00 & 0.0014 \\
\hline 37.8 & 1012.4 & 4.02 & 0.0012 \\
\hline 43.3 & 1009.6 & 4.03 & 0.0011 \\
\hline 48.9 & 1006.8 & 4.04 & 0.0010 \\
\hline 54.4 & 1003.7 & 4.05 & 0.0009 \\
\hline 60 & 1000.5 & 4.06 & 0.0008 \\
\hline
\end{tabular}




\section{Appendix B: Experimental Uncertainty Analysis}

\section{B1: Uncertainty of Sensors and Calibrators}

The uncertainty analysis was performed on the mechanical system equipment that are analyzed in the Chapter 4. Two error sources were considered in the uncertainty analysis in this experiment. The first is the accuracy of sensors reading. The second source of error is the accuracy value of calibrators which is listed in Table B1. The use of high accuracy calibrators in the settings of this experiment lead to a negligible error. However, the calibrator accuracy is included in the analysis. The random errors have been neglected in this analysis since the data were inspected for all errors (ASHRAE Guideline 2, 2010). A list of the sensors and the accuracy is shown in Table B2.

Table B.1 : Manufacturer supplied calibrators and accuracy.

\begin{tabular}{|c|c|c|c|c|}
\hline Calibrator name & Calibrator type & Manufacturer & Model number & Calibrator accuracy \\
\hline Elster Amco Water Meter & Flow meters & Elster Amco & N/A & $\pm 1.5 \%$ \\
\hline Micro Calibration Bath & Calibrate RTD & Sika & TP M 165 S & $\pm 0.05^{\circ} \mathrm{C}$ \\
& & & & \\
\hline
\end{tabular}


Table B.2 : Manufacturer, sensors and accuracy

\begin{tabular}{|c|c|c|c|c|c|}
\hline Sensor name & Sensor type & $\begin{array}{c}\text { Manufactur } \\
\text { er }\end{array}$ & Location & $\begin{array}{c}\text { Model } \\
\text { number }\end{array}$ & $\begin{array}{c}\text { Sensor } \\
\text { accuracy }\end{array}$ \\
\hline $\begin{array}{c}\text { Air temperature } \\
\text { \& Relative } \\
\text { humidity }\end{array}$ & AT and RH & $\begin{array}{c}\text { Dwyer } \\
\text { Instruments } \\
\text { Inc. }\end{array}$ & $\begin{array}{c}\text { AHU } \\
\text { Supply/Return } \\
\text { Duct }\end{array}$ & Series RHT-D & $\begin{array}{l} \pm 1.5 \% \\
\pm 3.0 \%\end{array}$ \\
\hline $\begin{array}{l}\text { Metering flow } \\
\text { switch }\end{array}$ & $\begin{array}{c}\text { Mixture flow } \\
\text { rate }\end{array}$ & $\begin{array}{c}\text { Proteus } \\
\text { Industries Inc. }\end{array}$ & GSHP supply & $\begin{array}{c}\text { Proteus } \\
\text { 08016BN40QC }\end{array}$ & $\pm 3.0 \%$ \\
\hline $\begin{array}{c}\text { Metering flow } \\
\text { switch }\end{array}$ & $\begin{array}{l}\text { Mixture flow } \\
\text { rate }\end{array}$ & $\begin{array}{c}\text { Proteus } \\
\text { Industries Inc. }\end{array}$ & $\begin{array}{c}\text { Vertical loop- } \\
\text { A supply }\end{array}$ & $\begin{array}{c}\text { Proteus } \\
\text { 08012BN16QC }\end{array}$ & $\pm 3.0 \%$ \\
\hline $\begin{array}{c}\text { Metering flow } \\
\text { switch }\end{array}$ & $\begin{array}{c}\text { Mixture flow } \\
\text { rate }\end{array}$ & $\begin{array}{c}\text { Proteus } \\
\text { Industries Inc. }\end{array}$ & $\begin{array}{c}\text { Vertical loop- } \\
\text { B supply }\end{array}$ & $\begin{array}{c}\text { Proteus } \\
\text { 08012BN16QC }\end{array}$ & $\pm 3.0 \%$ \\
\hline $\begin{array}{l}\text { Metering flow } \\
\text { switch }\end{array}$ & $\begin{array}{c}\text { Mixture flow } \\
\text { rate }\end{array}$ & $\begin{array}{c}\text { Proteus } \\
\text { Industries Inc. }\end{array}$ & $\begin{array}{l}\text { Horizontal } \\
\text { loop supply }\end{array}$ & $\begin{array}{c}\text { Proteus } \\
\text { 08012BN16QC }\end{array}$ & $\pm 3.0 \%$ \\
\hline $\begin{array}{c}\text { Metering flow } \\
\text { switch }\end{array}$ & $\begin{array}{c}\text { Mixture flow } \\
\text { rate }\end{array}$ & $\begin{array}{c}\text { Proteus } \\
\text { Industries Inc. }\end{array}$ & $\begin{array}{c}\text { GSHP to } \\
\text { buffer tank }\end{array}$ & $\begin{array}{c}\text { Proteus } \\
\text { 0812BN19 }\end{array}$ & $\pm 3.0 \%$ \\
\hline Wattnode & $\begin{array}{c}\text { Electrical } \\
\text { energy }\end{array}$ & $\begin{array}{c}\text { Continental } \\
\text { Control } \\
\text { Systems }\end{array}$ & $\begin{array}{c}\text { Devices } \\
\text { Consuming } \\
\text { Electricity }\end{array}$ & WNB-3Y-208-P & $\pm 1.0 \%$ \\
\hline $\begin{array}{c}\text { RTD sensor } \\
\text { (Pt.500, directly } \\
\text { immersed) }\end{array}$ & Temperature & AAlTO Inc. & $\begin{array}{c}\text { Most of the } \\
\text { pipes }\end{array}$ & Pt.500 & $\pm 3.0 \%$ \\
\hline
\end{tabular}


For this purpose, the Square Root Sum of Squares (SRSS) method was followed which combines all errors or accuracy by squaring them, adding the squares together and taking the square root of the sum of those squares (ASHRAE Guideline 2, 2005).

Overall accuracy of sensors $=\sqrt{A_{c}^{2}+A_{s}^{2}}$

where $\mathrm{A}_{\mathrm{c}}=$ Calibrator accuracy, and $\mathrm{A}_{\mathrm{s}}=$ Sensor accuracy .

The overall accuracy of sensors from Equation (B-1) was used in the propagation of errors calculation to determine the accuracy of mechanical system equipment. The propagation of errors is the method of computing the uncertainty in a result which depends on several variables each with its own uncertainty. Generally, the uncertainty of a result is expressed in terms of a standard deviation or absolute uncertainty, $\sigma$, which has the same units as the quantity or in terms of a fractional or relative uncertainty, shown as $\varepsilon$. For the uncertainty of $x$, the relationship between $\sigma$ and $\varepsilon$ can be defined as:

$$
\varepsilon \equiv \frac{\sigma_{x}}{x}
$$

The relative uncertainty can also be expressed as a percentage. Thus the number $100 \pm 1$ $\mathrm{mm}$ can be also expressed as $100 \mathrm{~mm} \pm 1 \%$. Table B.3 shows the common formulas used for propagating uncertainty. The calculated uncertainties errors are shown below in Table B 4.

Table B.3 : Mathematical operation of propagating uncertainty

\begin{tabular}{|c|c|c|}
\hline Calculation & Formula & Uncertainty Formula \\
\hline Sum / Difference & $f=x+y, f=x-y$ & $\sigma_{f}=\sqrt{\sigma_{x}^{2}+\sigma_{y}^{2}}$ \\
\hline $\begin{array}{c}\text { Multiplication / } \\
\text { Division }\end{array}$ & $f=x y, f=\frac{x}{y}$ & $\varepsilon_{f}=\sqrt{\varepsilon_{x}^{2}+\varepsilon_{y}^{2}}$ \\
\hline
\end{tabular}


Table B.4 : Uncertainty in the calculations

\begin{tabular}{|l|c|}
\hline \multicolumn{1}{|c|}{ Variable } & Maximum uncertainty (\%) \\
\hline Mass flow rate & \pm 3.3 \\
\hline Electrical power & \pm 1.0 \\
\hline Air temperature & \pm 3.0 \\
\hline Fluid temperature & \pm 3.0 \\
\hline Temperature difference & \pm 4.2 \\
\hline Cooling/heating output & \pm 4.6 \\
\hline GSHP COP & \pm 8.6 \\
\hline
\end{tabular}




\section{Appendix C: One Cycle Sample Of Operation}

C.1: Heating mode using the vertical loops.

One cycle sample of the test period is shown in this section. The sample was taken on May 25, 2013 at 2:30 pm. During the test period, the average outside air temperature was $13^{\circ} \mathrm{C}$.

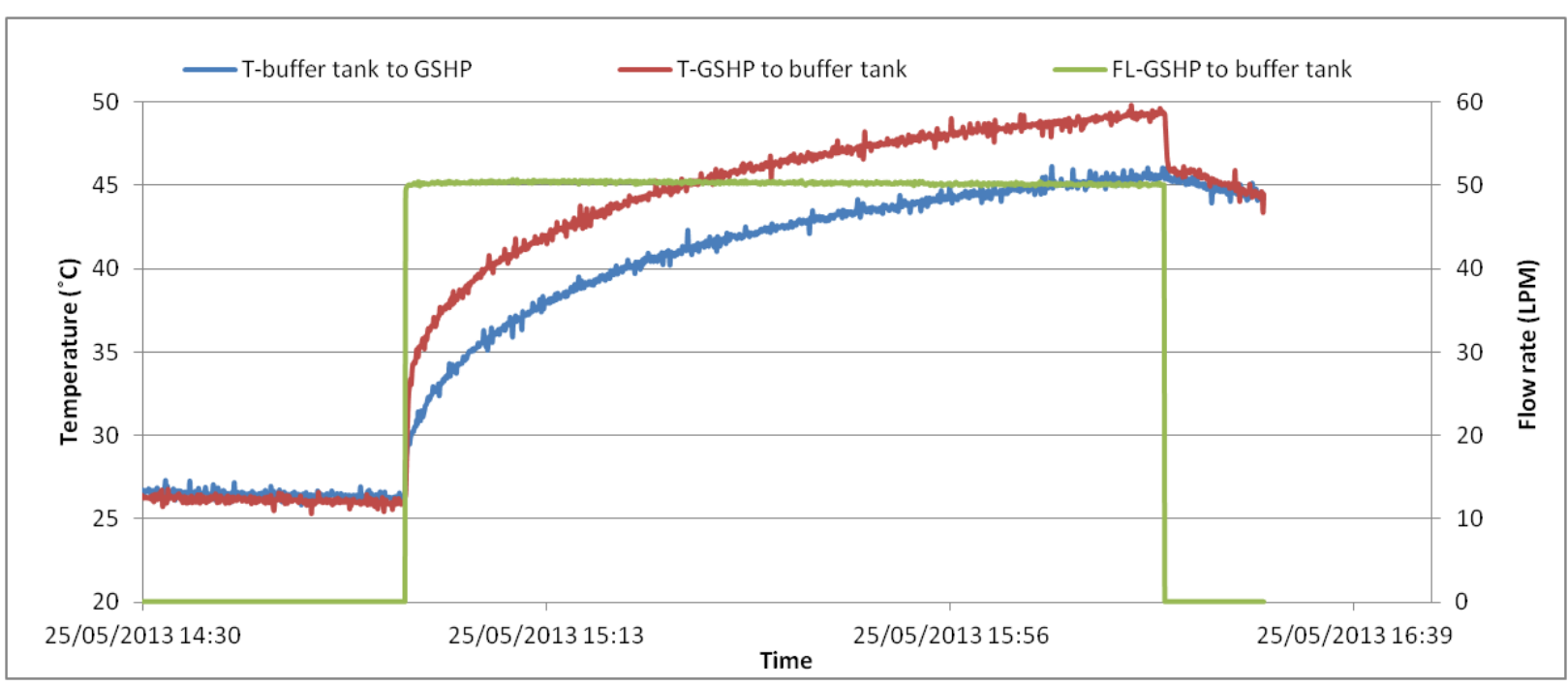

Figure C.1 : One cycle sample of the supply and return temperatures to the GSHP from the buffer tank

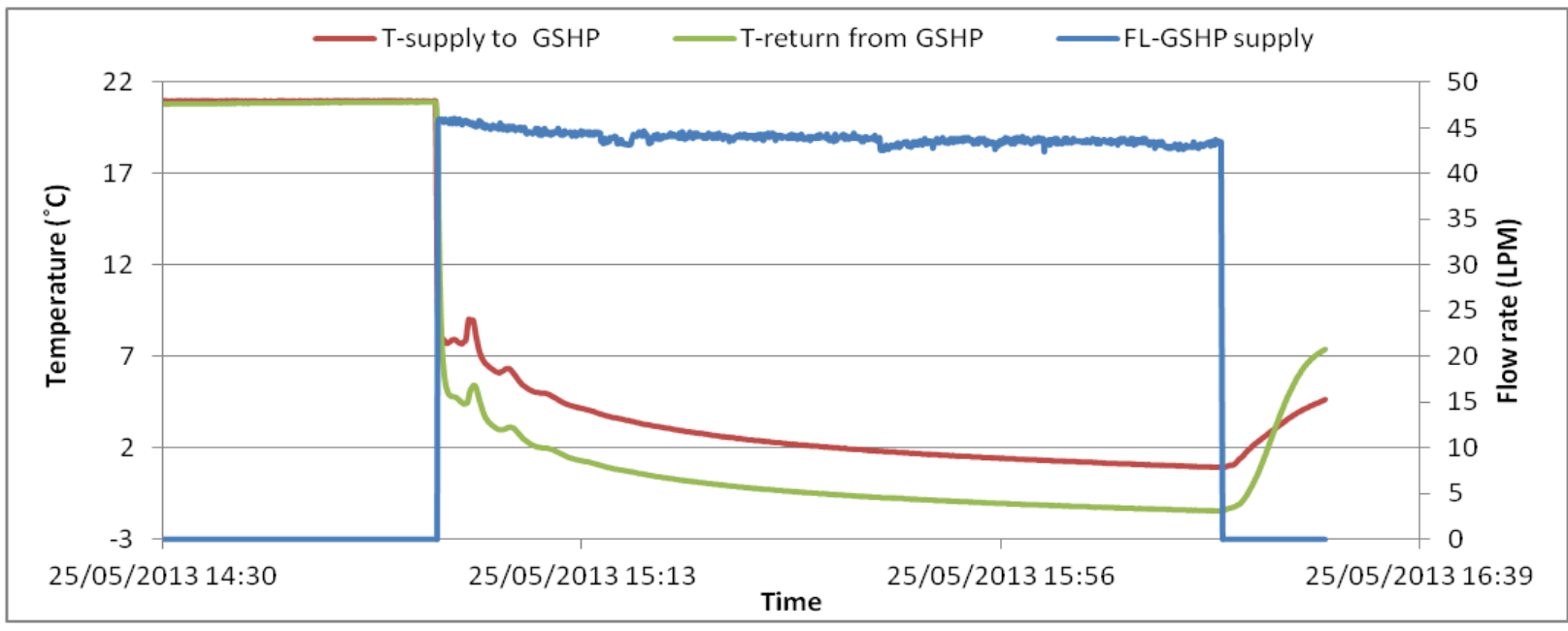

Figure C.2 : One cycle sample of the supply and return temperatures to the GSHP from the vertical loop 


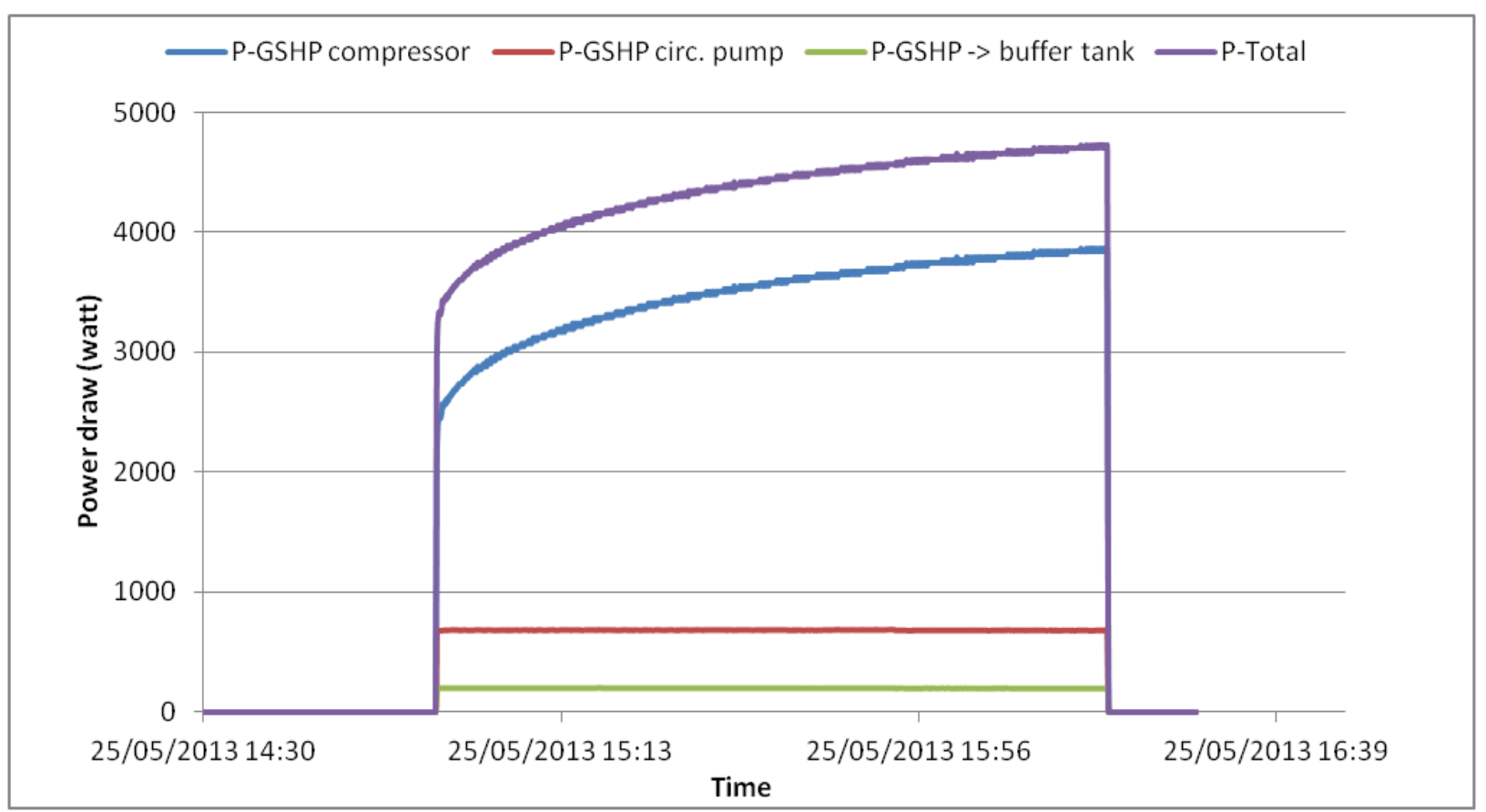

Figure C.3 : One cycle sample of the power draw of the GSHP system components

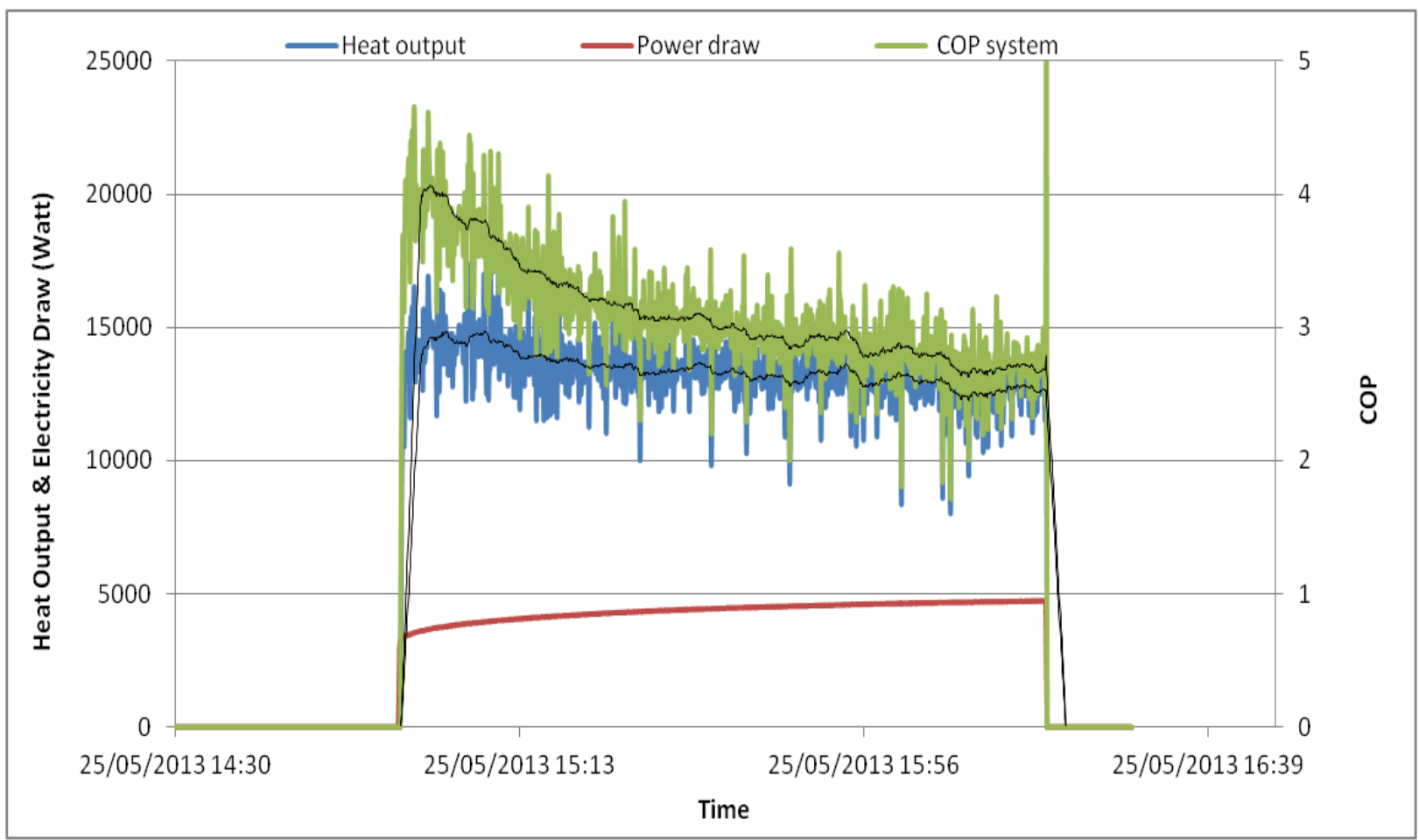

Figure C.4 : One cycle sample of the heating output, power draw and the COP. 
C.2: Cooling mode using the vertical loops.

One cycle sample of the second test period is shown in this section. The sample was taken on July 1, 2013 at 11:00 am. During the test period, the average outside air temperature was $22^{\circ} \mathrm{C}$.

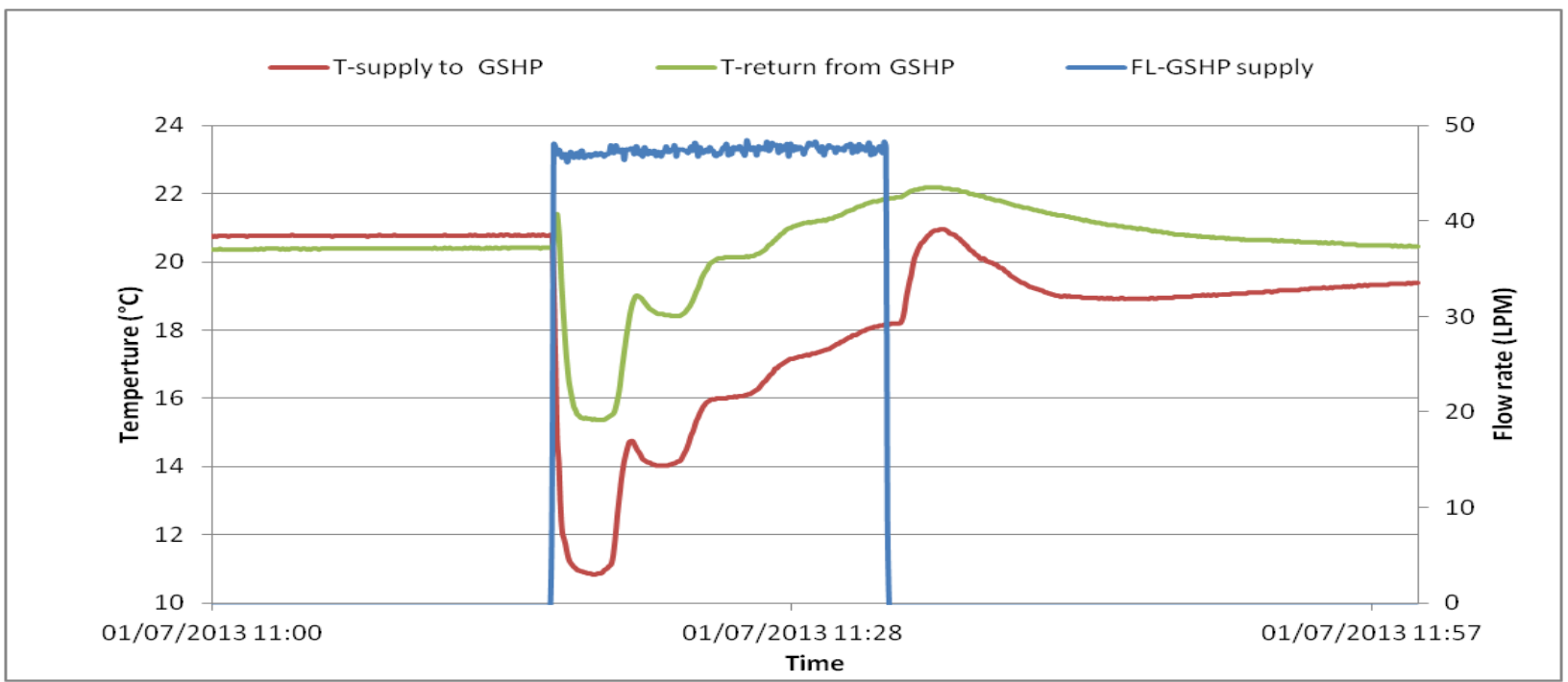

Figure C.5 : One cycle sample of the supply and return temperatures to the GSHP from the vertical loop

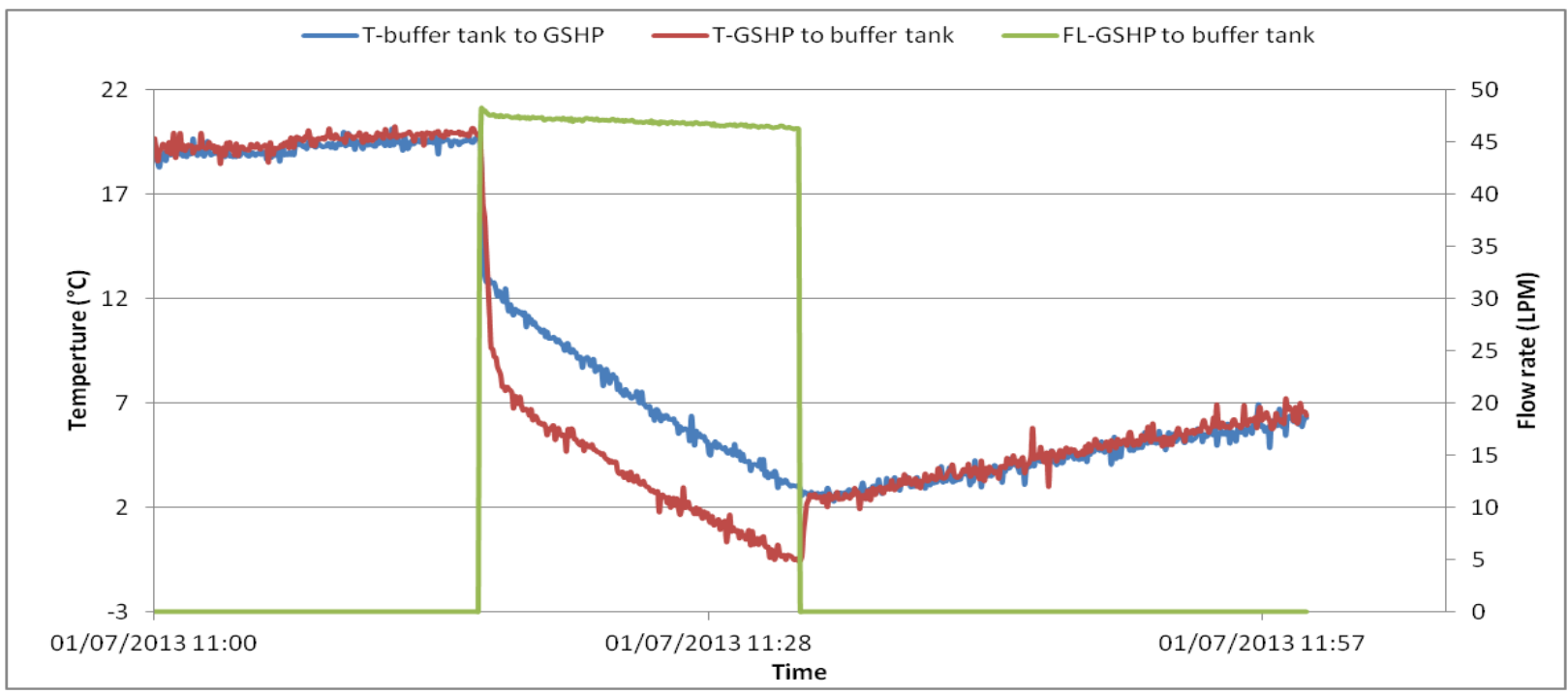

Figure C.6 : One cycle sample of the supply and return temperatures to the GSHP from the buffer tank 


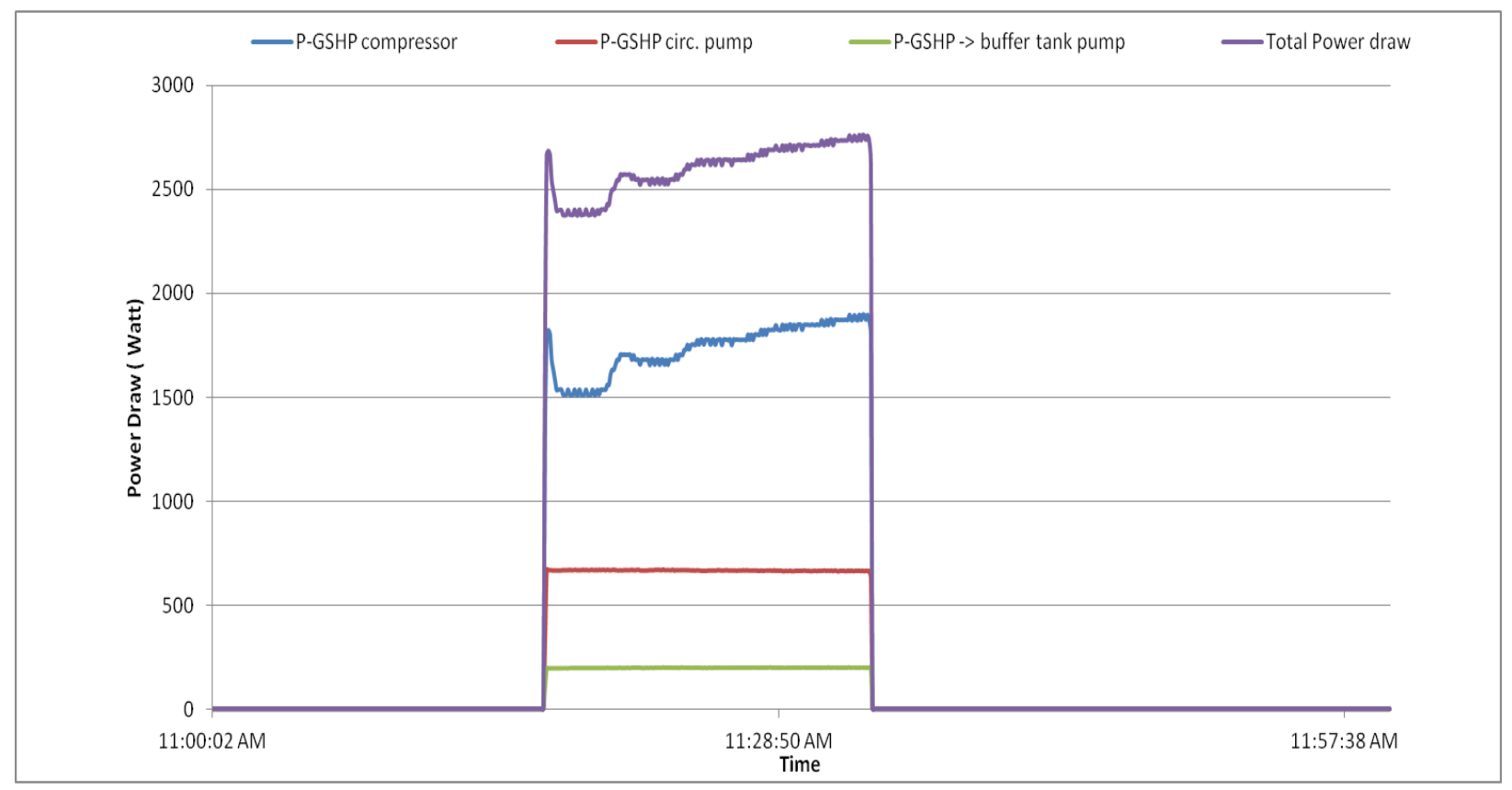

Figure C.7 : One cycle sample of the GSHP system components power draw

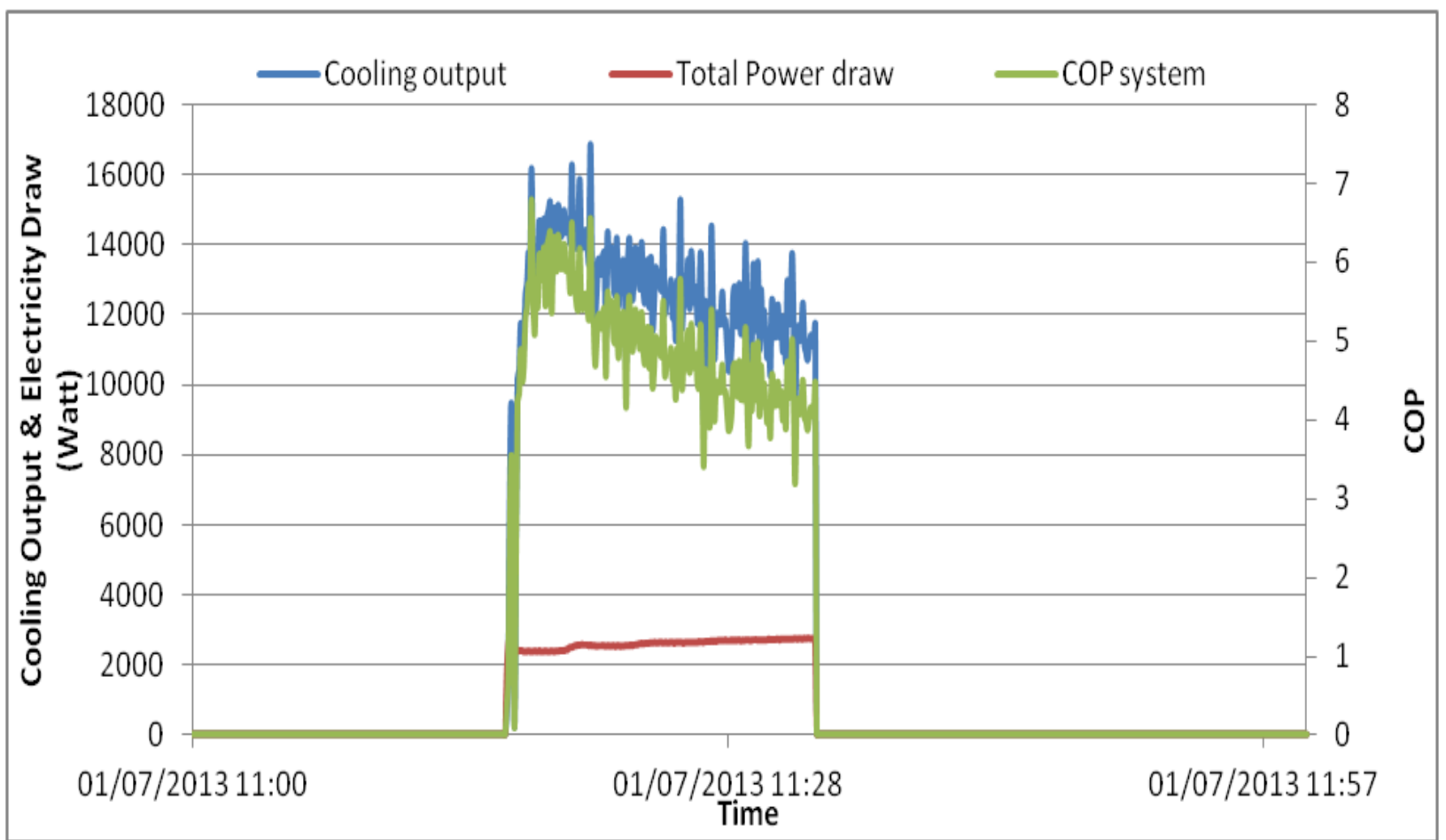

Figure C.8 : One cycle sample of the cooling output, power draw and the COP 
C.3: Cooling mode using the vertical and the horizontal loops with equal flow.

One cycle sample of the third test period is shown in this section. The sample was taken on July 19, 2013 at 5:00 am. During the test period, the average outside air temperature was $26^{\circ} \mathrm{C}$.

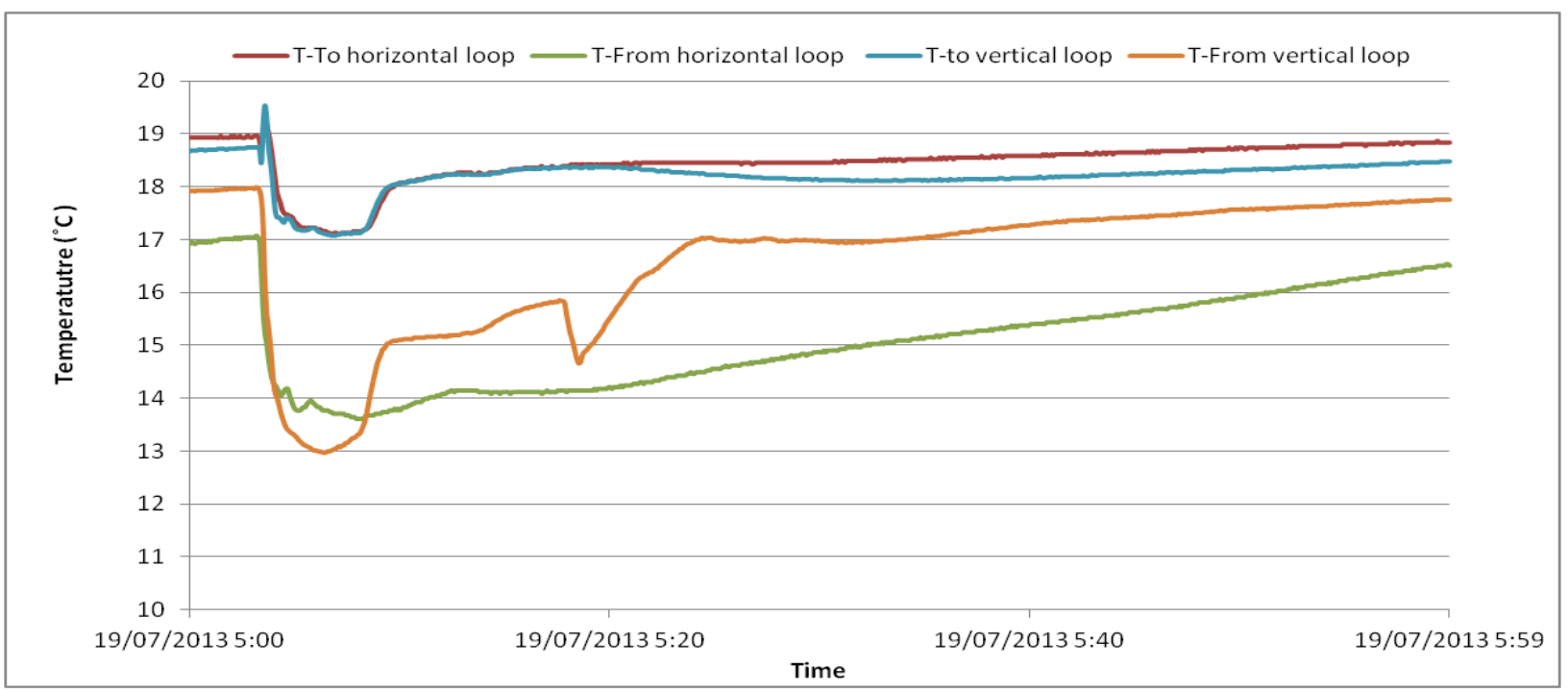

Figure C.9 : One cycle sample of the supply and return temperatures from the vertical and horizontal ground loops

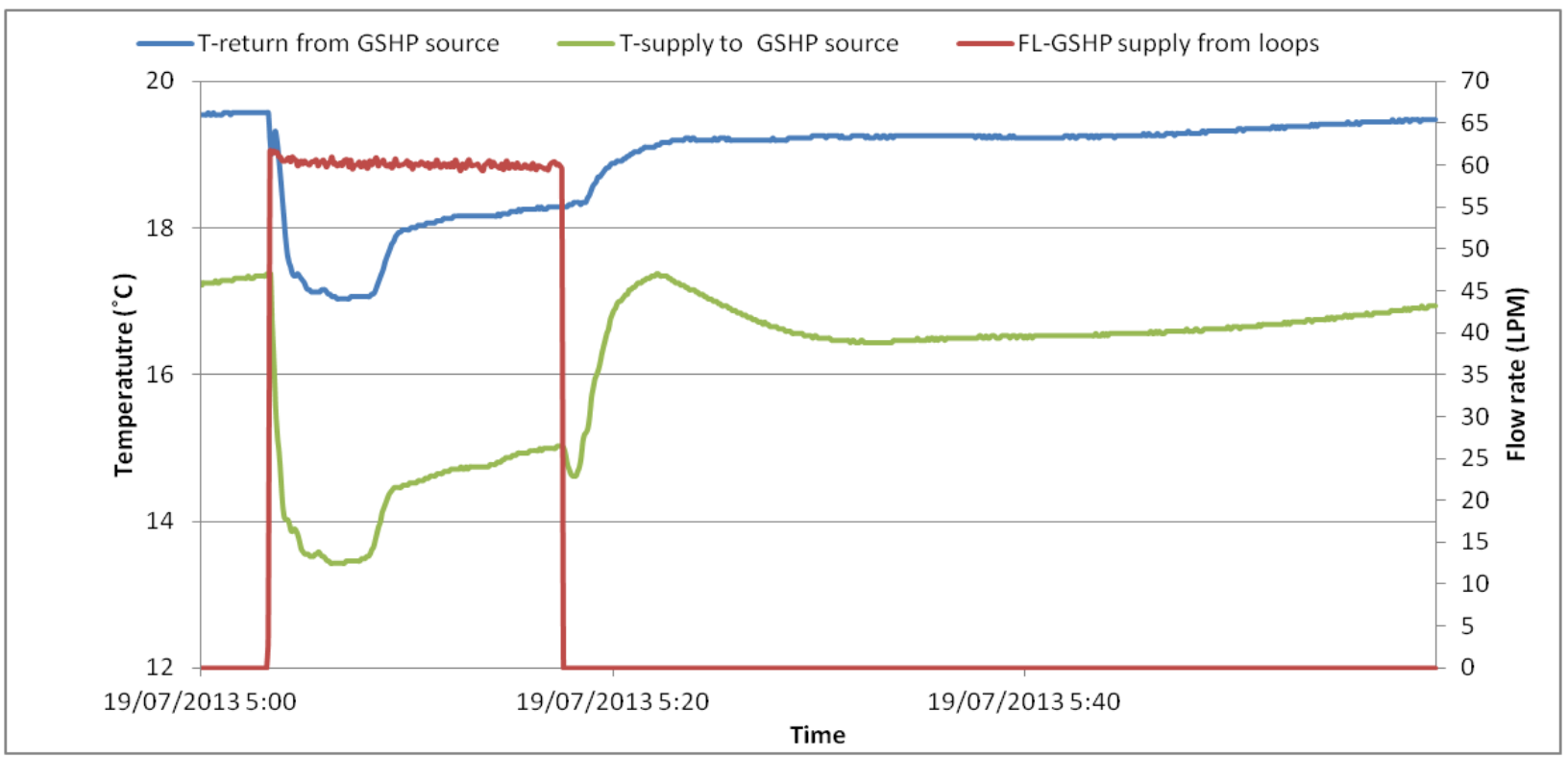

Figure C.10 : One cycle sample of the supply and return temperatures to the GSHP from the ground loops 


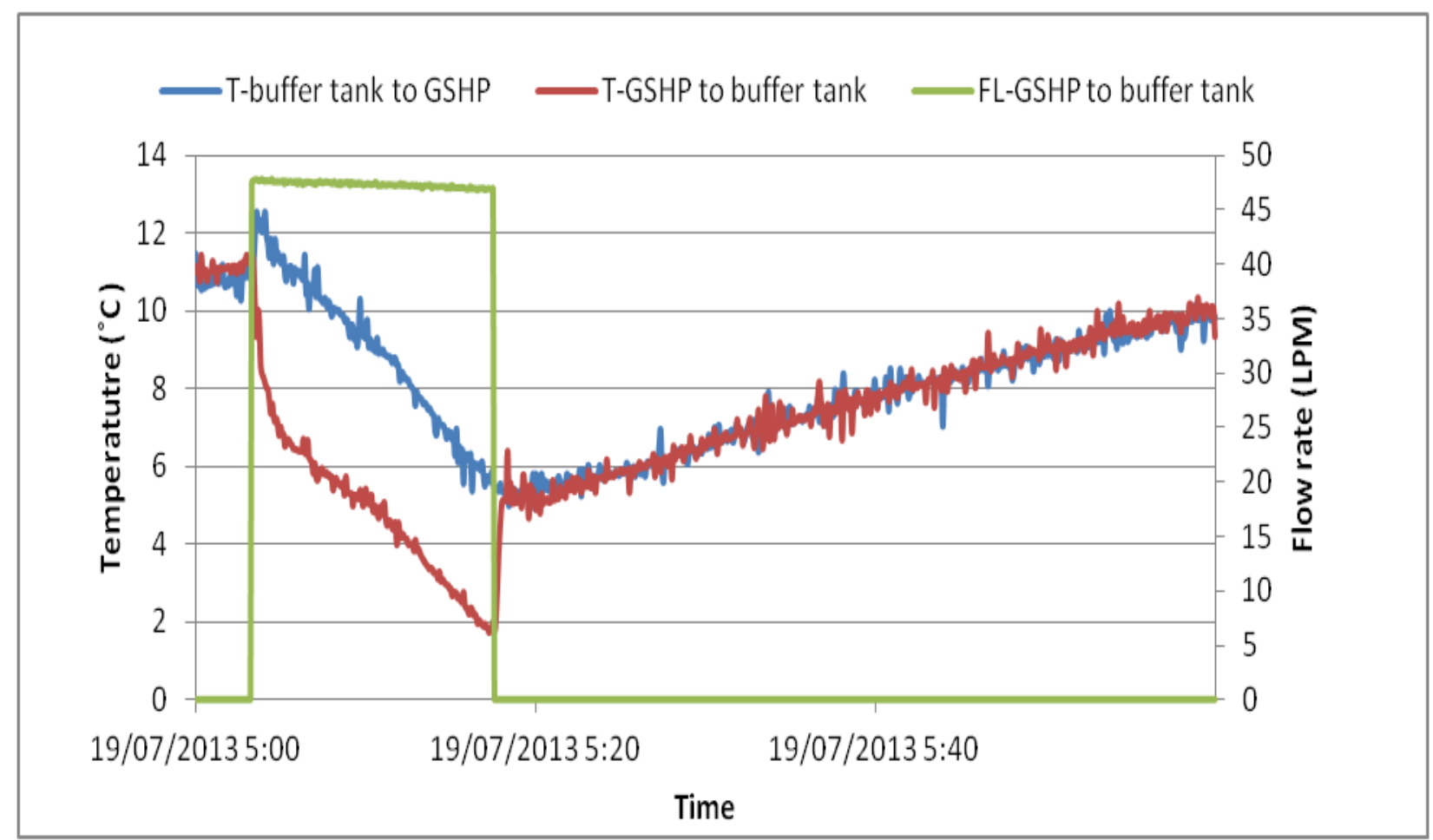

Figure C.11 : One cycle sample of the supply and return temperatures to the GSHP from the buffer tank

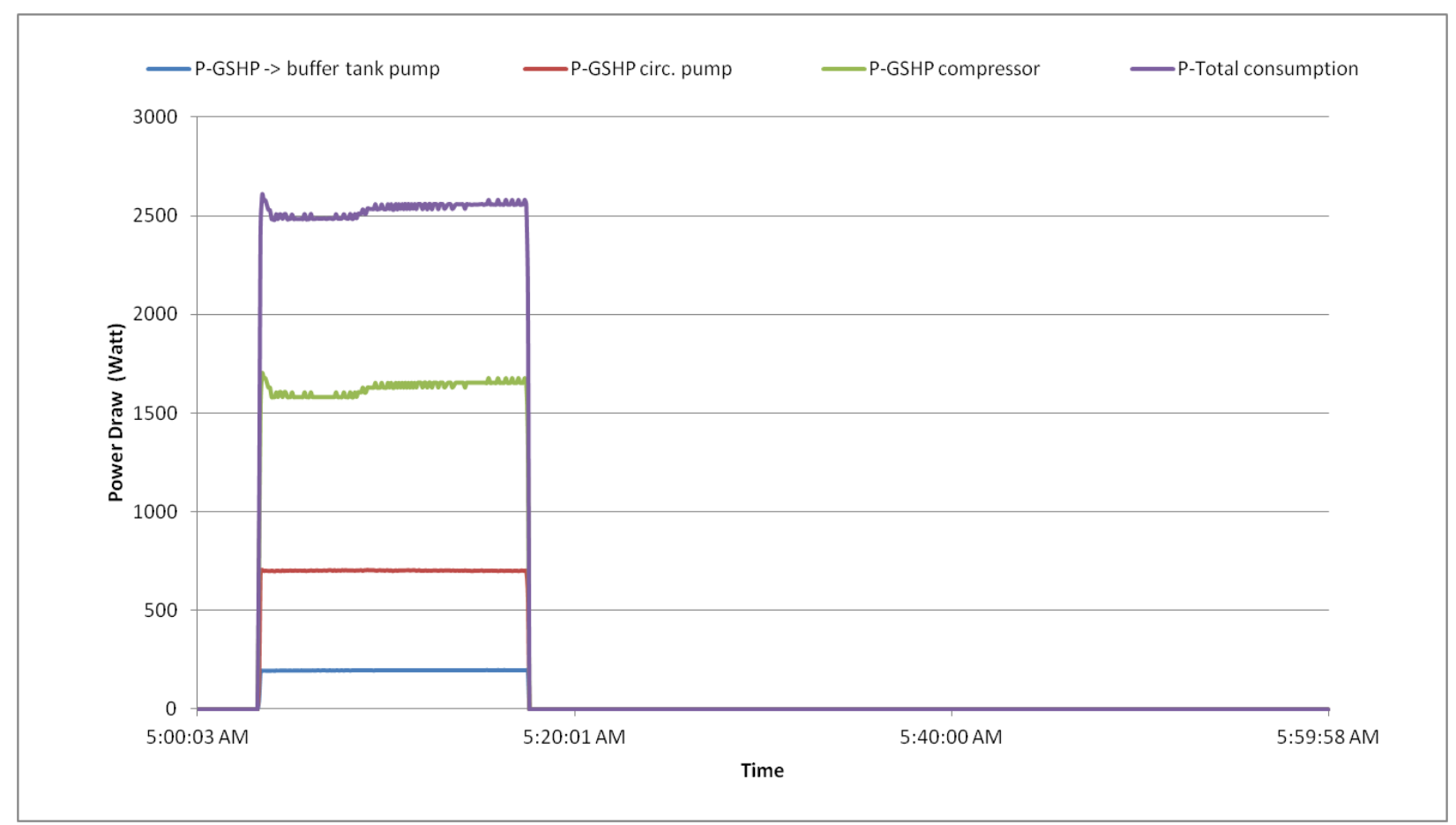

Figure C.12 : One cycle sample of the GSHP components power draw 


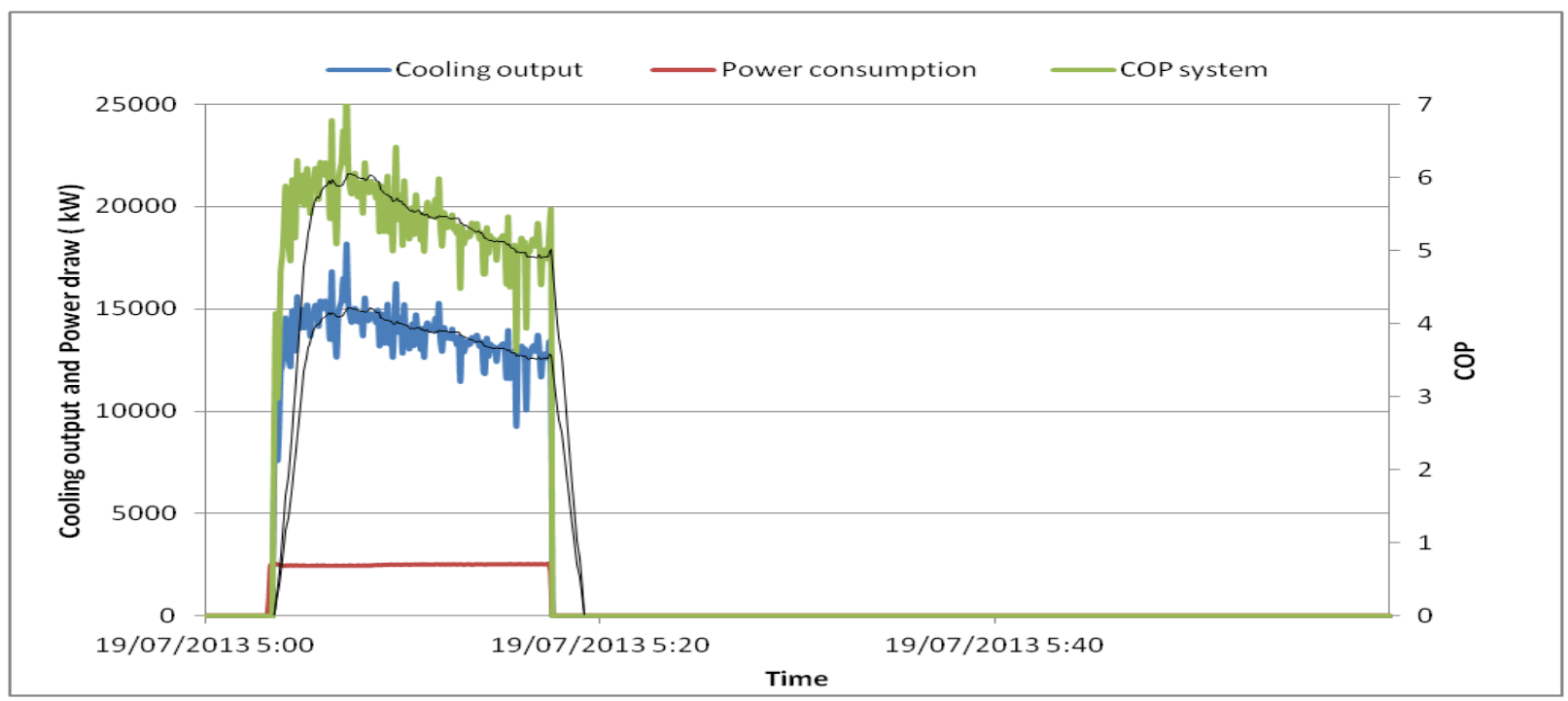

Figure C.13 : One cycle sample of the GSHP cooling output, power draw and the COP

C.4: Cooling mode using the vertical and the horizontal loops with equal Reynolds number.

One cycle sample of the fourth test period is shown in this section. The sample was taken on August 8, 2013 at noon. During the test period, the average outside air temperature was $26^{\circ} \mathrm{C}$.

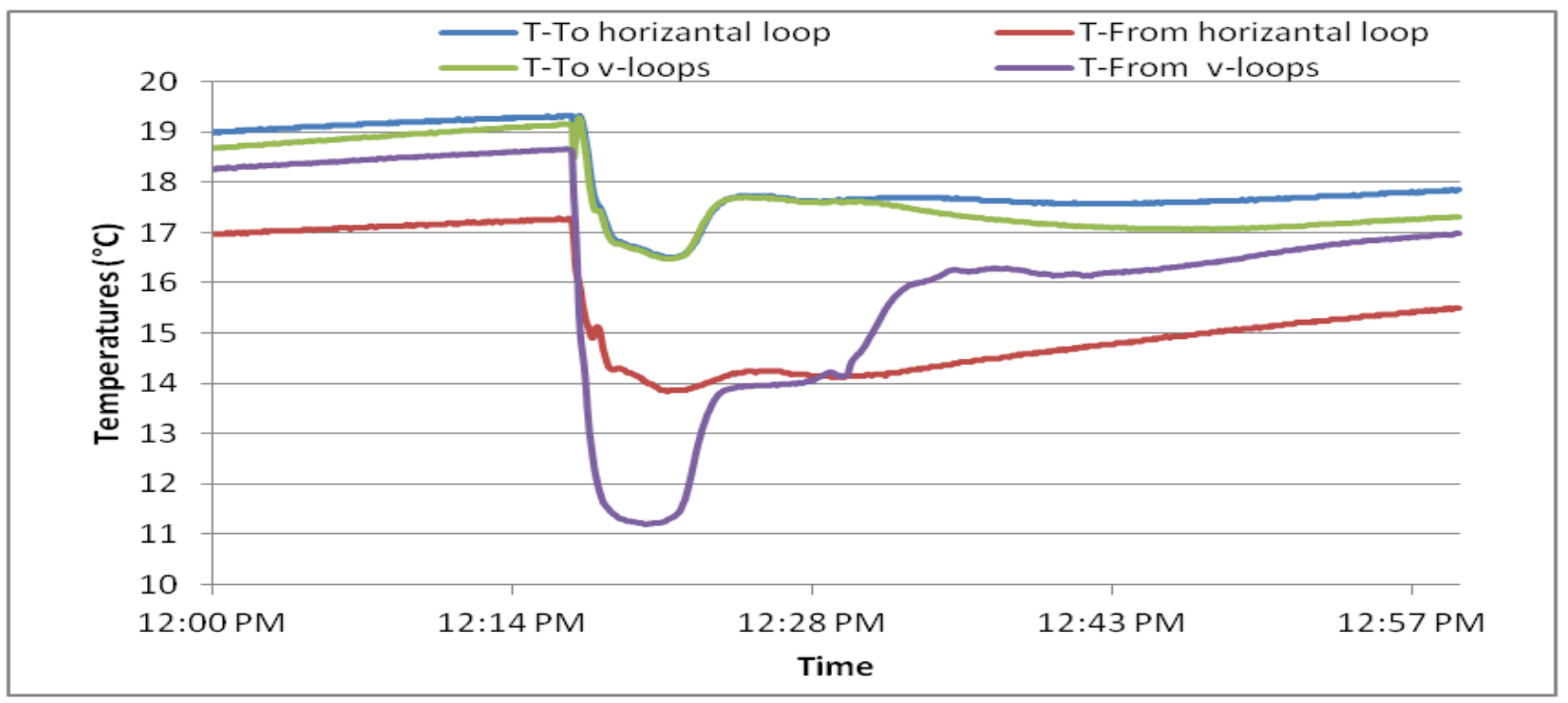

Figure C.14 : One cycle sample of the supply and return temperatures from the vertical and horizontal ground loops 


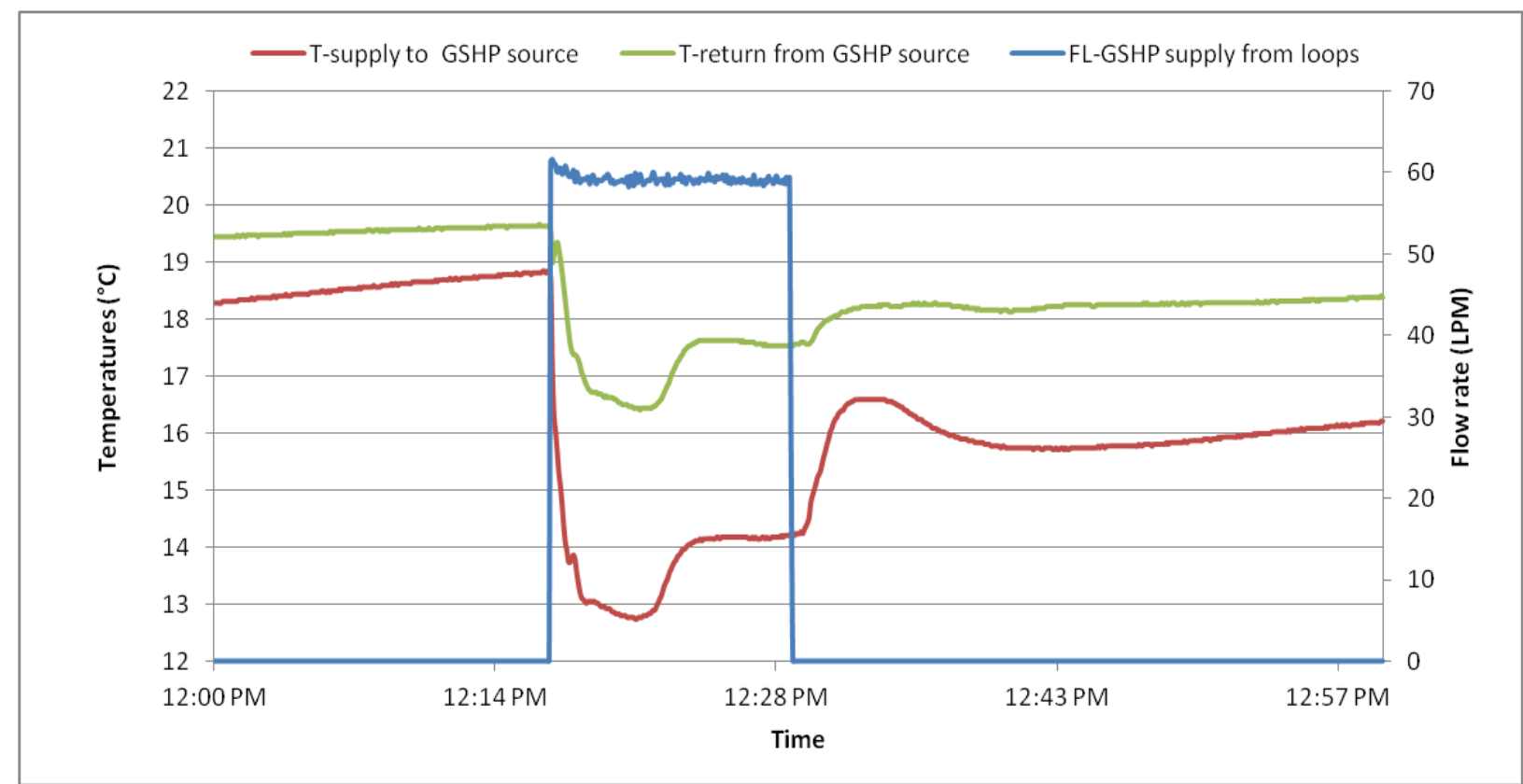

Figure C.15 : One cycle sample of the supply and return temperatures to the GSHP from the ground loops

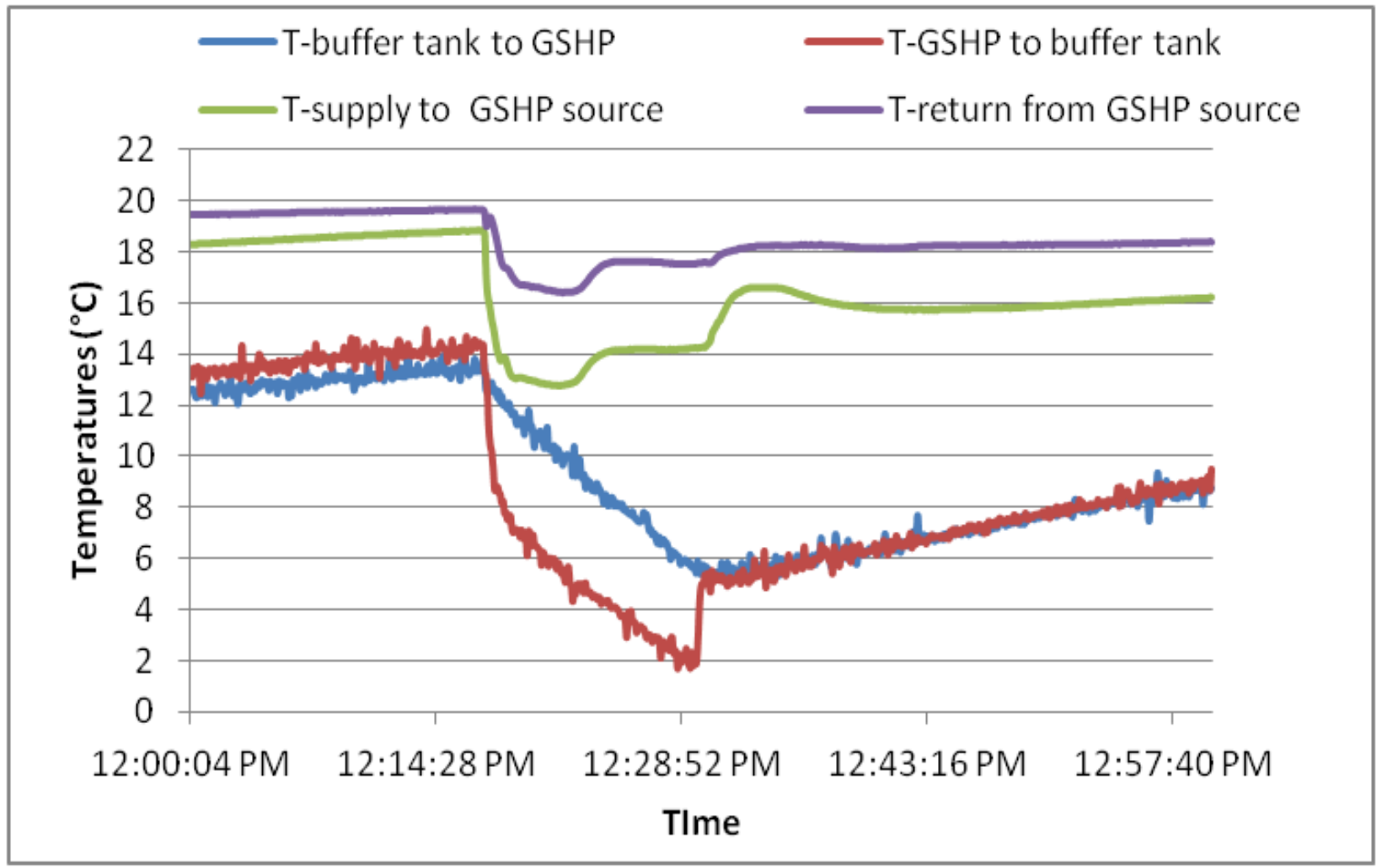

Figure C.16 : One cycle sample of the supply and return temperatures to the GSHP from ground loops and the buffer tank 


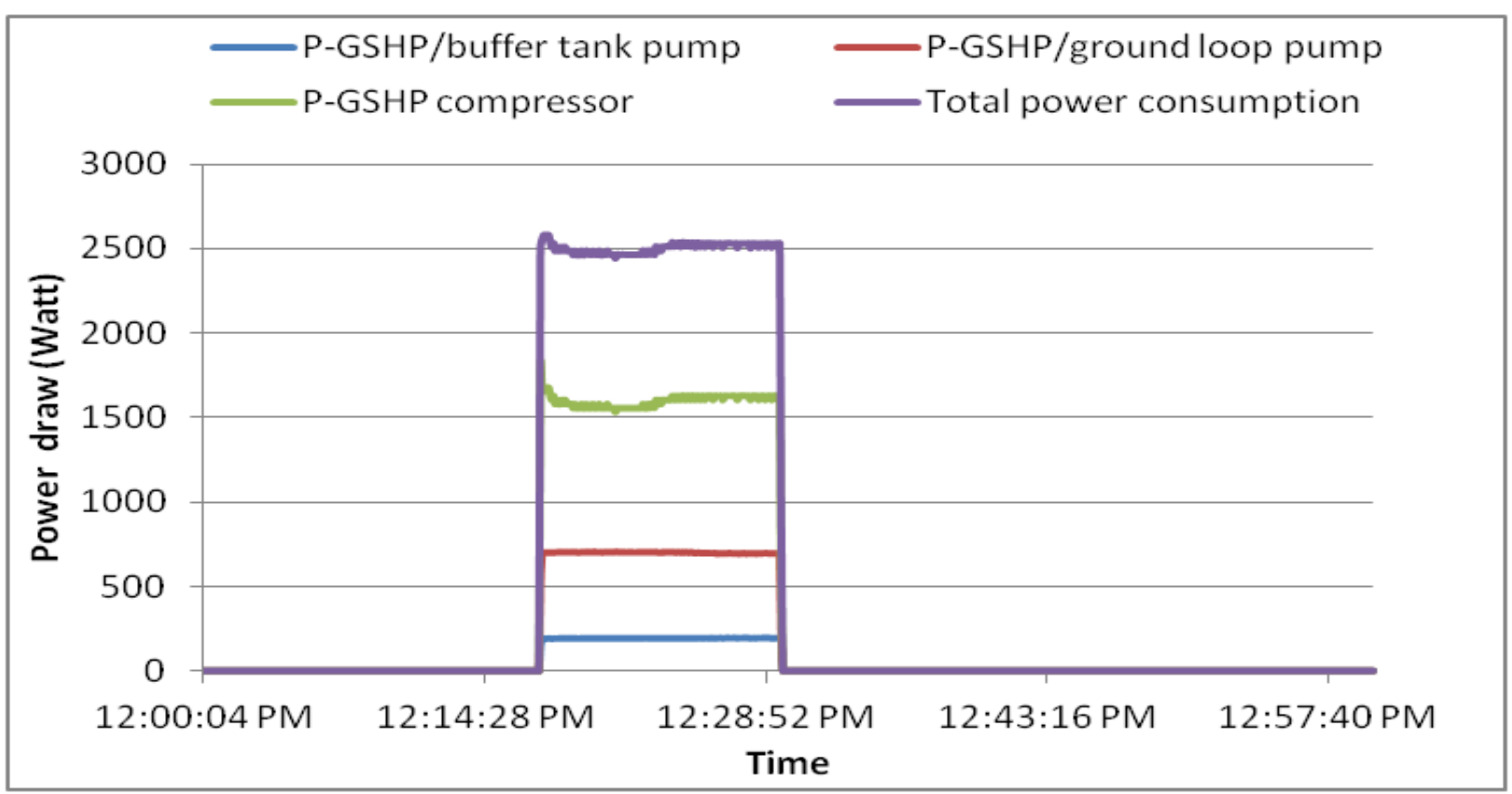

Figure C.17 : One cycle sample of the GSHP system components power draw

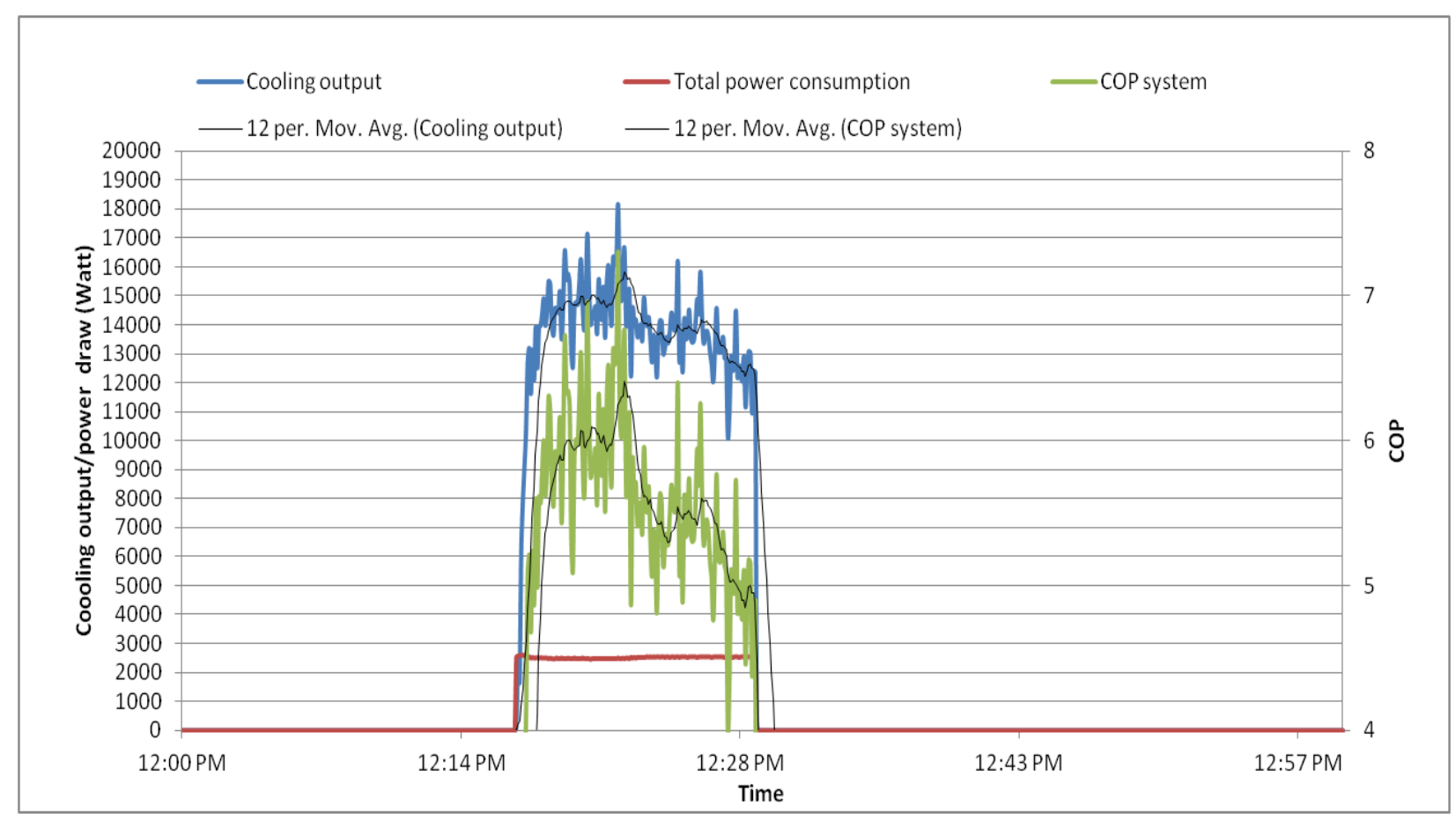

Figure C.18 : One cycle sample of the GSHP cooling output, power draw and the COP 


\section{Appendix D: Horizontal Loops Length Calculations.}

\section{D.1 Lithium test results:}

Two samples from the horizontal loops were collected and sent for analysis to determine the size of the horizontal loops. The first sample was taken with only the water/PG mixture in the loop. Then, a lithium sample was added to the loop with known concentration and volume and circulated in the loop. After few days of circulation, the second sample was collected and sent for analysis. From the concentration of lithium in the second sample, the volume of the horizontal loop was calculated to be 732 L. Figure D. 1 shows the lithium test results.

\section{CHEMMLDL}

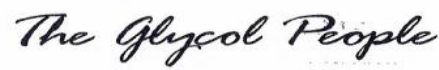

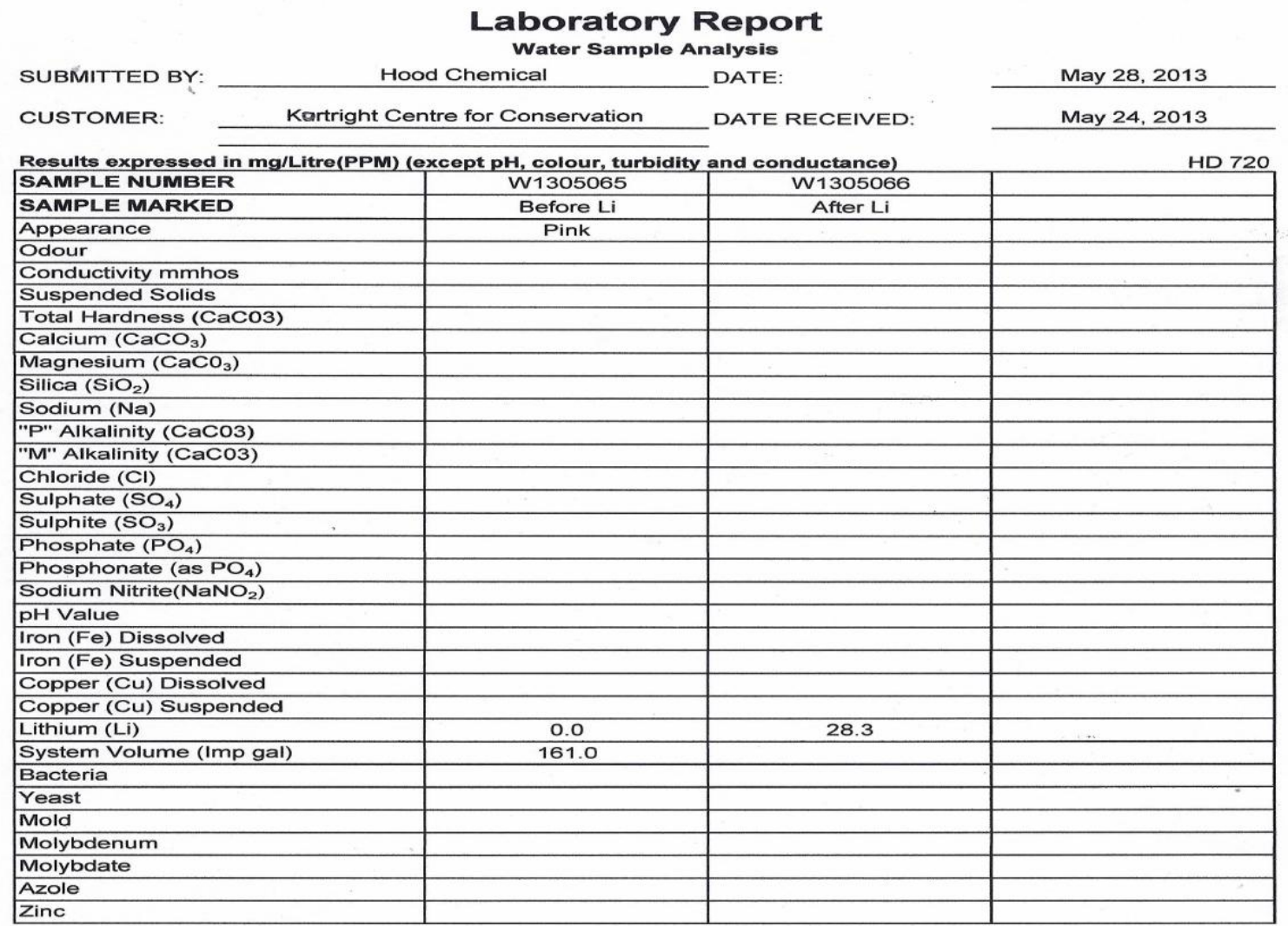

Figure D.1 : Lithium test results 


\section{D.2 Horizontal loop length calculations:}

From the lithium test, the total volume of the two horizontal loops and the connection from the house GSHP to the beginning of the two horizontal loops turned out to be 732 Liters (161 Imp gal). The supply and the return pipes from the house GSHP to the beginning of the two horizontal loops have a measured length of $25 \mathrm{~m}(82.021 \mathrm{ft})$ and an inner diameter of $4.0894 \mathrm{~cm}$ $\left(1.61^{\prime \prime}\right)$. The volume of the supply and the return pipes from the GSHP in the basement to the beginning of the two horizontal loops, $\boldsymbol{V}_{\mathbf{1}}$, was calculated as follow:

$V_{1}=\pi\left(\frac{D_{1}}{2}\right)^{2}\left(2 L_{1}\right)$

$V_{1}=\pi\left(\frac{0.040894}{2}\right)^{2}(2 \times 25)=0.06567 \mathrm{~m}^{3}=65.67 \mathrm{~L}$

Where:

$V_{1}$ : The volume of the supply and the return pipes from the GSHP to the beginning of the two horizontal loops

$\boldsymbol{D}_{\mathbf{1}}$ : Inner diameter of the supply and the return pipes from the GSHP to the beginning of the two horizontal loops $(0.040894 \mathrm{~m})$

$\boldsymbol{L}_{\mathbf{1}}$ : Length of the supply and the return pipes from the GSHP to the beginning of the two horizontal loops $(25 \mathrm{~m})$

The remaining of the volume, $\boldsymbol{V}_{2}$, was used to calculate the length of the horizontal loops as follow:.

$V_{2}=V_{\text {total }}-V_{1}=732-65.67=666.33 \mathrm{~L}=0.66633 \mathrm{~m}^{3}$

$L_{2}=\frac{V_{2}}{2 \pi\left(\frac{D_{2}}{2}\right)^{2}}=\frac{0.66633}{2 \pi\left(\frac{0.034036}{2}\right)^{2}}=366 \mathrm{~m}$

Where:

$\boldsymbol{V}_{2}$ : The volume of the two horizontal loops

$\boldsymbol{D}_{2}$ : Inner diameter of the two horizontal loops $(0.034036 \mathrm{~m})$

$\boldsymbol{L}_{2}$ : Length of one horizontal loop 


\section{REFERENCES}

ASHRAE. (2009). 2009 ASHRAE Handbook - Fundamentals I-P Edition. American Society of Heating, Refrigerating and Air-Conditioning Engineers, Inc.

ASHRAE Guideline 2, (2010). Engineering Analysis of Experimental Data. Atlanta GA, USA: ASHRAE.

Bakirci, K, (2010), Evaluation of The Performance of a Ground-Source Heat-Pump System with Series GHE (Ground Heat Exchanger) in the Cold Climate Region. Energy, vol. 35, p. 30883096.

Barua, R. (2010). Assessment and energy benchmarking for two archetype sustainable houses through comprehensive long term monitoring. Toronto: Ryerson University.

Benli, H, (2013), A performance comparison between a horizontal source and a vertical source heat pump systems for a greenhouse heating in the mild climate Elazig, Turkey, Applied Thermal Engineering, vol. 50, p. 197-206.

Canadian GeoExchange Coalition. (2011). The State of the Canadian Geothermal Heat Pump Industry 2011: Industry Survey and Market Analysis,.

Dembo, A., Ng, R., Pyrka, A., \& Fung, A. (2009). The Archetype Sustainable House: Investigating its potentials to achieving the net-zero energy status based on the results of a detailed energy audit. West Lafayette: Purdue University. 
Dembo, A., NG, R., Pyrka, A., \& Fung, A. (2010). The Archetype Sustainable House:

Investigating its potentials to achieving the net-zero energy status based on the results of a detailed energy audit. International High Performance Buildings Conference. Purdue, Indiana.

Doherty, P., Al-Huthaili, S., Riffat, S., \& Abodahab, N. (2004). Ground Source Heat PumpDescription and Preliminary Results of the Eco House System. Applied Thermal Engineering, vol. 24, p. 2627-2641.

GeoEnergy Solutions Inc. 2011. Report on a geothermal energy test borehole and an in-site thermal conductivity test.

Hwang, Y., Lee, J., Jeong, Y., Koo, K., Lee, D., Kim, I., Jin, S., Kim, S.H., 2009, Cooling performance of a vertical ground-coupled heat pump system installed in a school building, Renewable Energy, vol. 34: p. 578-582.

Inalli M., Esen H., (2004), Experimental thermal performance evaluation of a horizontal groundsource heat pump system, Applied Thermal Engineering, vol. 24, p. 2219-2232.

Inherent energy. (2010). Retrieved June 1, 2013:

http://www.inherentenergy.co.uk/groundsource.html

Kara, Y. A. (2007), Experimental performance evaluation of a closed-loop vertical ground source heat pump in the heating mode using energy analysis method. International Journal of Energy Research, vol. 31, p. 1504-1516. 
Kima A., Leea J., Jeonga Y., Hwanga Y., Leeb S., Parkb N., 2012, Performance evaluation under the actual operating condition of a vertical ground source heat pump system in a school building, Energy and Buildings, vol. 50, p. 1-6.

Lee, C., Park, M., Nguyen, T.B., Sohn, B., Choi, J.M., \& Choi, H.,(2012), Performance evaluation of closed-loop vertical ground heat exchangers by conducting in-situ thermal response tests, Renewable Energy, vol. 42, p. 77-83

Li, H., Nagano, K., Lai, Y., Shibata, K., \& Fujii, H., (2013). Evaluating the performance of a large borehole ground source heat pump for greenhouses in northern Japan, Energy, vol. 63, p. 387-399

Luo, J., Rohn, J., Bayer, M., Priess, A., (2013), Thermal performance and economic evaluation of double U-tube borehole heat exchanger with three different borehole diameters, Energy and Buildings, vol. 67, p. 217-224.

Michopoulos, A., Bozis, D., Kikidis, P., Papakostas, K., \& Kyriakis, N.A., (2007). Three-Years Operation Experience of a Ground Source Heat Pump System in Northern Greece. Energy and Buildings, vol. 39, p. 328-334.

Michopoulos, A., Zachariadis, T., Kyriakis, N.,(2013), Operation characteristics and experience of a ground source heat pump system with a vertical ground heat exchanger, Energy, vol. 51, p. 349-357. 
Naili N., Attar I., Hazami M., Farhat A.,2013, First in situ operation performance test of ground source heat pump in Tunisia, vol. 75, p. 292-301.

NRCan. (2012a). Energy Use Data Handbook: 1990 to 2009, 2012, Natural Resources Canada.

NRCan. (2012b). Report to Parliament Under the Energy Efficiency Act For the Fiscal Year 2010-2011, 2012 Natural Resources Canada.

NRCan. (2005). Clean Energy Project Analysis: RETSCREEN Engineering \& Cases Textbook.

Ozgener, O., \& Hepbasli, A., (2005) Performance analysis of a solar-assisted ground-source heat pump system for greenhouse heating: an experimental study, Building and Environment, vol. 40, p. $1040-1050$.

Pelmorex Media Inc., 2013. The Weather Network Statistics: North York, ON. Online document:

http://www.theweathernetwork.com/forecasts/statistics/degreedays/c1615s001/caon0710

Safa, A. 2012. Performance Analysis of a two stage variable capacity air source heat pump and a horizontal ground loop coupled ground source heat pump system. Master of Applied Science thesis, Department of Mechanical and Industrial Engineering, Ryerson University. Toronto, Ontario. 
Wang, X., Ma C., \& Lu Y. (2009), An experimental study of a direct expansion ground-coupled heat pump system in heating mode, International Journal of Energy Research, vol. 33, p. 13671383

Wang, X., Zheng, M., Zhang, W., Zhang, S., Yang, T., (2010), Experimental study of a solarassisted ground-coupled heat pump system with solar seasonal thermal storage in severe cold areas, Energy and Buildings, vol. 42, p. 2104-2110

Wibbels, M., \& Braven, K. (1994). The Effect of Cycling Operation of a Horizontal Ground Loop on Ground Coupled Heat Pump Performance. Journal of Solar Energy Engineering, vol. 1, p. 13-18.

Zhang, D., Barua, R., \& Fung, A. (2010). Development of Monitoring System for the Sustainable Archetype House at Kortright Centre. Purdue University

Zhang, D., Barua, R., \& Fung, A. (2011). TRCA-BILD Archetype Sustainable House: Overview of Monitoring System and Preliminary Results for Mechanical Systems. ASHRAE Transaction, vol. 117. 